Historic, Archive Document

Do not assume content reflects current scientific knowledge, policies, or practices. 


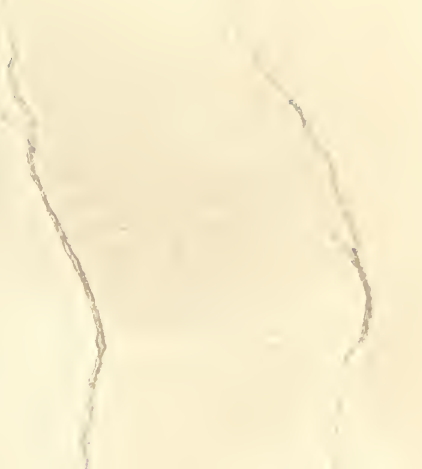




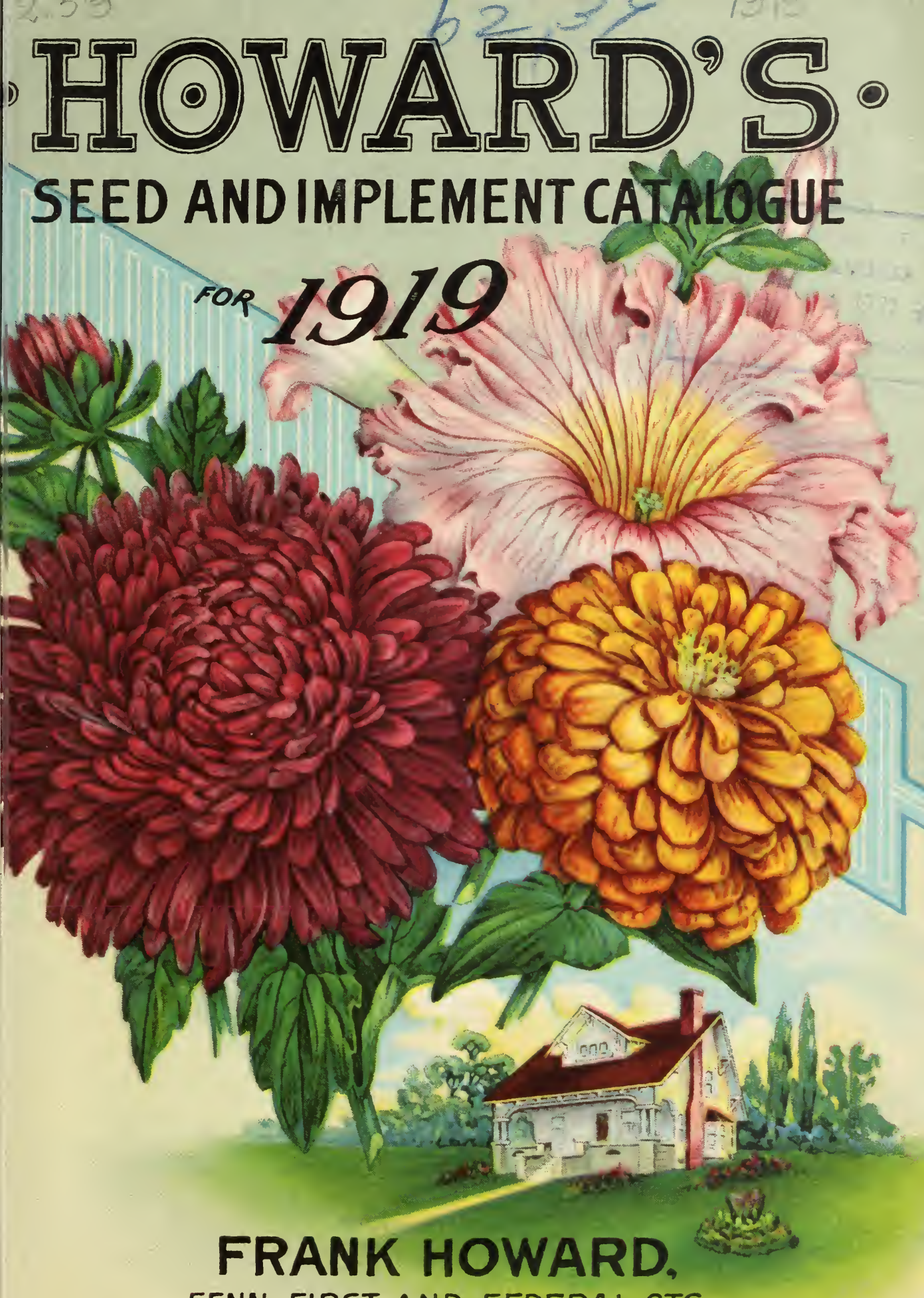

FENN, FIRST AND FEDERAL STS.

• PITTSFIELD, MASS . 


\section{OUR NEW STORE}

At the corner of FENN, FIRST and FEDERAL STREETS, near the post office, is arranged for your comfort and convenience while shopping. We occupy four floors, with elevator service, and entrances on Fenn, First and Federal Streets

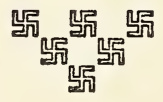

Make our store your headquarters while in the city. You are always welcome

\section{FRANK HOWARD}

\section{The Moline-Universal Tractor}

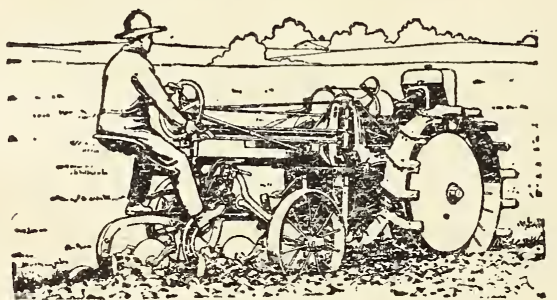

THE MOLINE-UNIVERSAL TRACTOR is the ideal tractor for the average size farm; turns in a 16-ft. circle; easier to handle than a (4) team; weight about the same, and will back with the implement attached; does practically all kinds of field work. Prices on application. $:: \quad:::$ : 


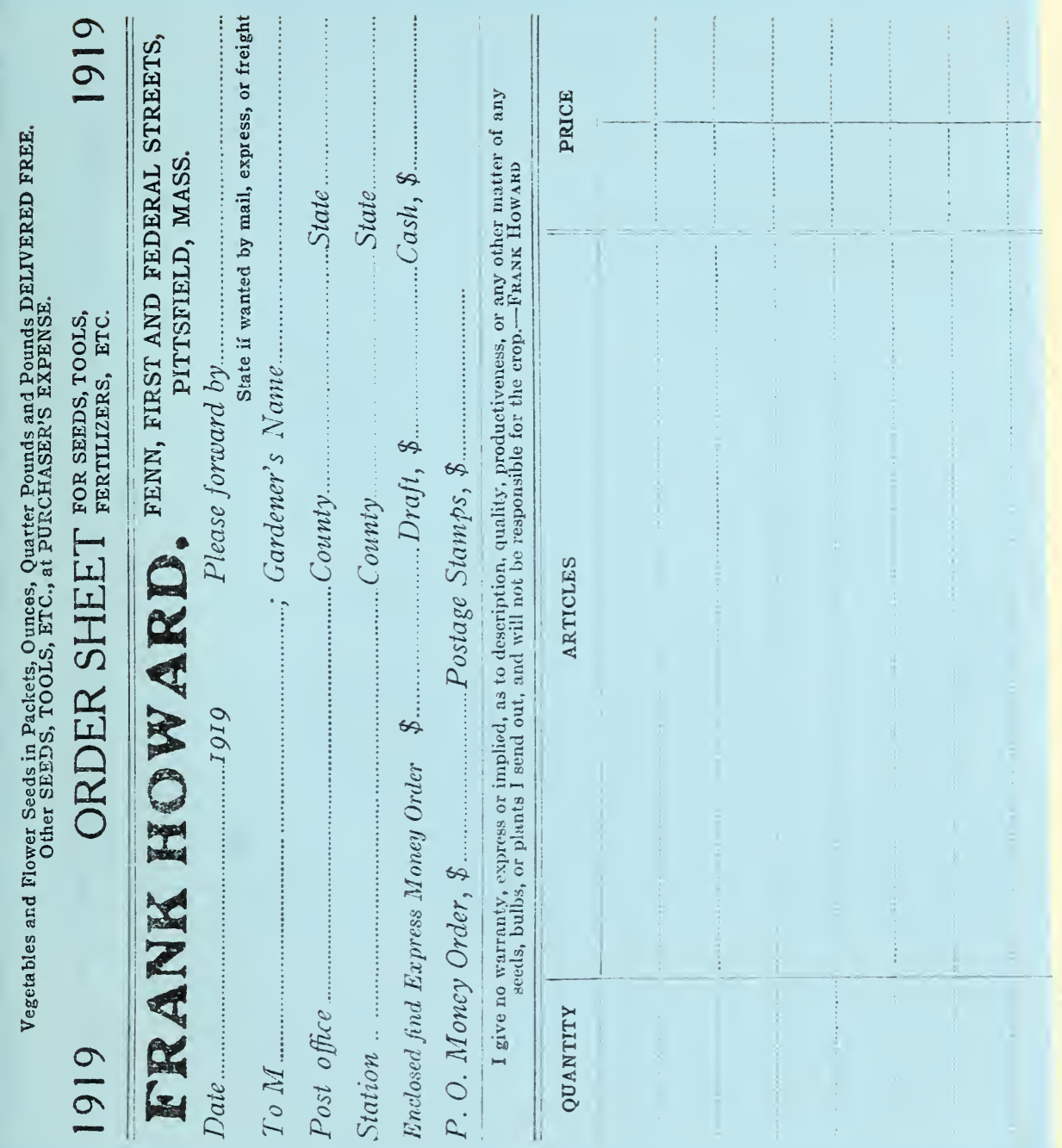




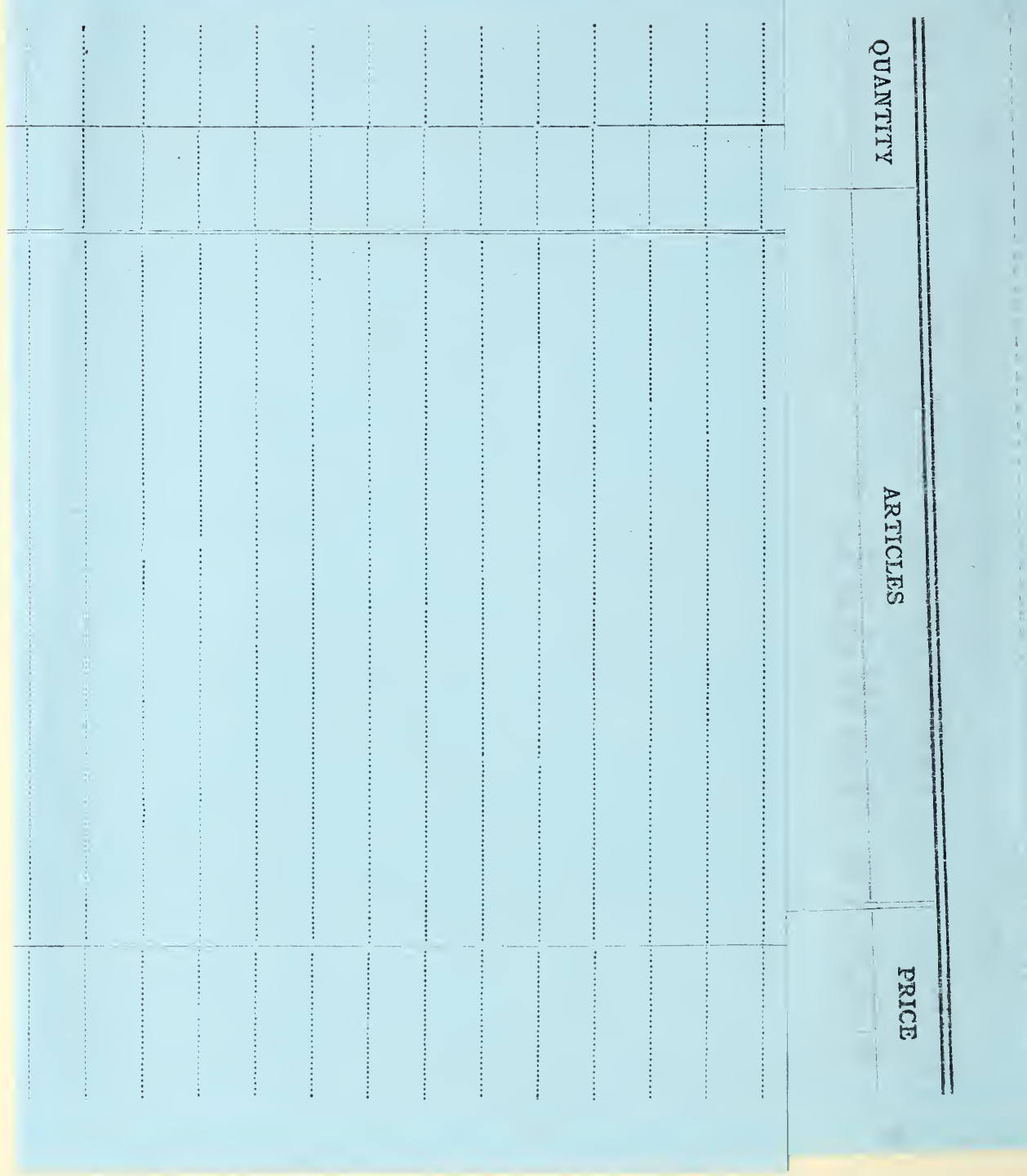




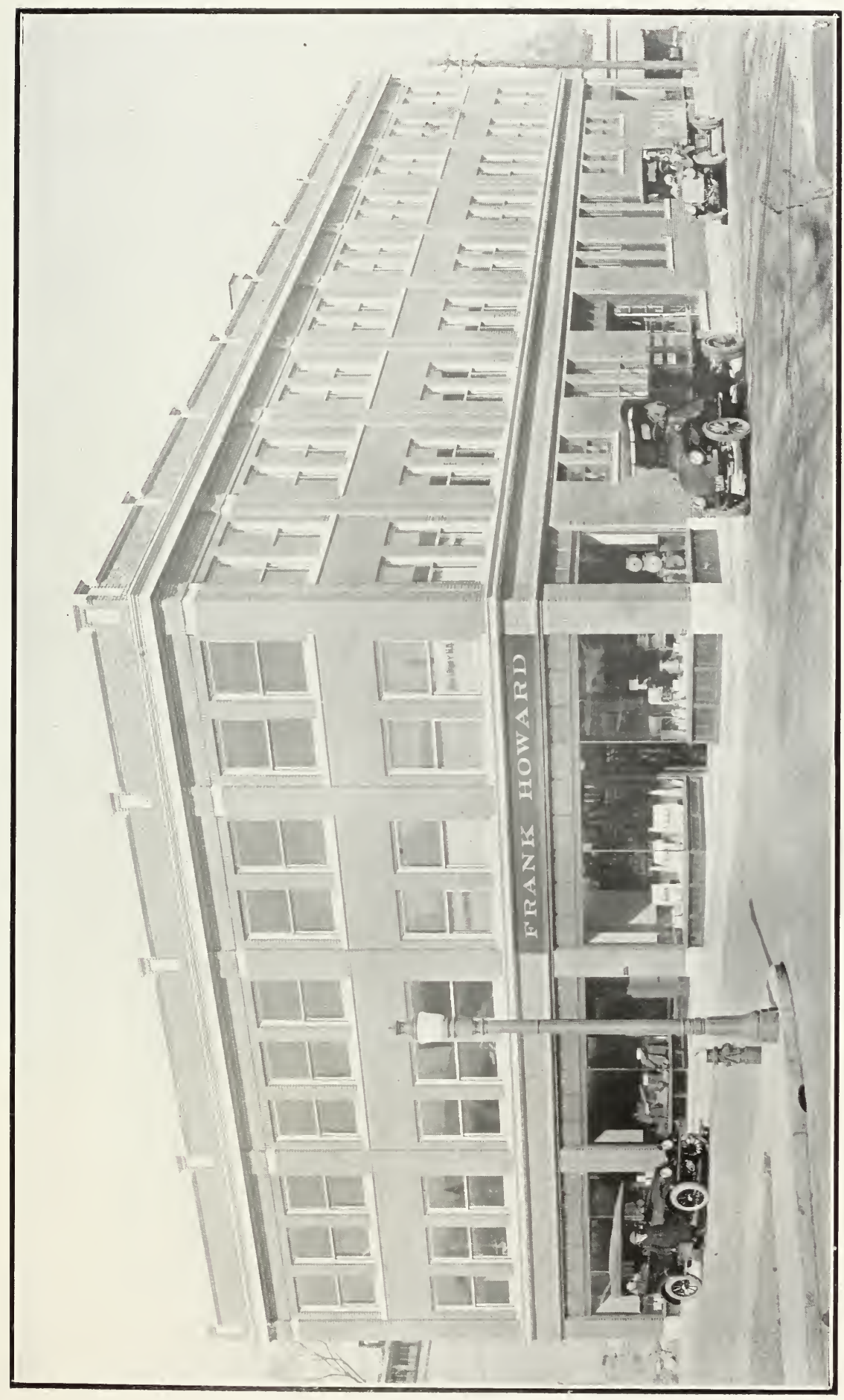

范

范

$\exists$

옹이

일. 요

홈

语昰

웡

部

준

D

红过

ㄴㅇㅇ

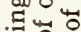

오.․․․

की

을을

ตั

군울 야

중

영 웡

o is

푤

넝 도옹

Eี :

ن용

잉

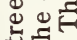

致。

范。

红

몯

ब

웡

I

है 


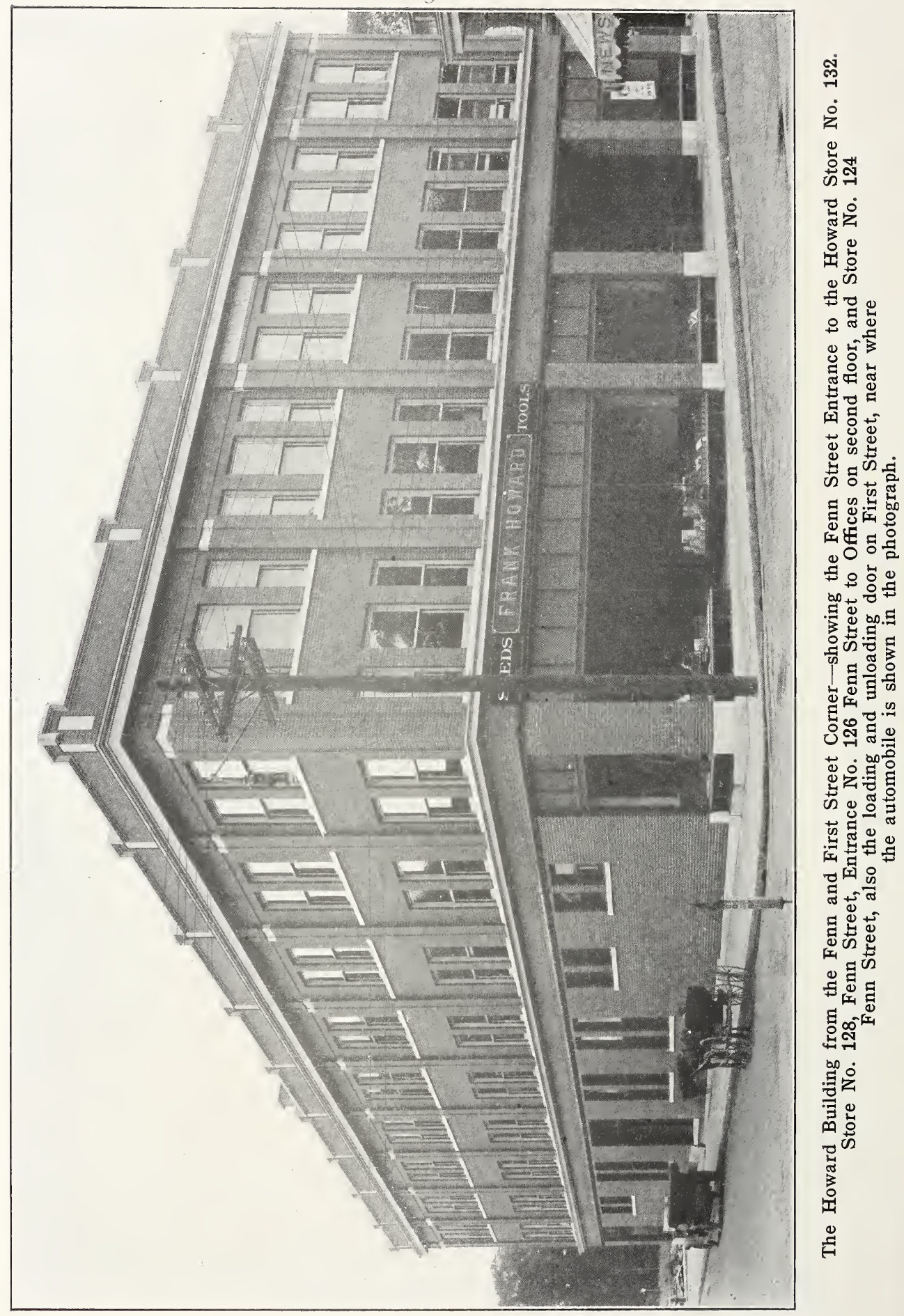




\section{9}

\section{FRANK}

HOWARD'S

\section{Annual Spring Catalog}

$\mathrm{OF}$

\section{Reliable "Seeds That Grow"}

\section{TOOLS and MACHINERY}

The Unsettled market conditions render it impossible to make firm prices. You can, however, depend on us at all times to give you BEST GOODS and at FAIR PRICES. PRICES HOWEVER ARE SUB JECT TO CHANGE WITHOUT NOTICE.

WE PAY POSTAGE or EXPRESS on SEEDS in PACKETS, OUNCES, QUARTERPOUNDS and POUNDS, on other seeds if WANTED BY MAIL ADD POSTAGE as per following table:

\section{PARCEL-POST ZONE RATES}

Within the United States

Zone Within

1 st .. 50 miles of Pittsfield .

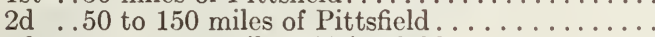

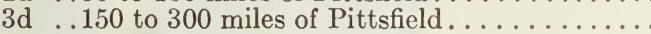

4 th . .300 to 600 miles of Pittsfield...........

5 th . .600 to 1,000 miles of Pittsfield ..........

6 th . .1,000 to 1,400 miles of Pittsfield . . . . . . .

7 th . .1,400 to 1,800 miles of Pittsfield.........

Sth . 1,800 and over miles of Pittsfield.........

Maximum weight, $70 \mathrm{lbs}$. to $1 \mathrm{st}$ and $3 \mathrm{~d}$ zones - and $50 \mathrm{lbs}$. from the 4 th zone upward.

"Our Seeds are Northern Grown, None Better at Any Price."

Our name is an absolute guarantee of the best in quality and price.

MAKE OUR STORE YOUR HEADQUARTERS WHILE IN THE CITY. YOU ARE ALWAYS WELCOME.

\section{Yours respectfully,}

FRANK HOWARD.

\section{GARDENER'S AND HEAD FARMER'S SITUATIONS}

WVe keep a register of names of Practical Gardeners and Farm Managers also Farm Laborers who are in want of situations. If parties desiring such will write to us we shall be glad to put them in communication with men that we deem suitable. To aid us in making a selection we ask full particulars, and whether a married or single man is wanted. We malke no charge for this service, either to employer or employee.

\section{SPECIAL NOTICE.}

I give no warranty, express or implied, as to description, quality, productiveness, or any other matter of any seeds, bulbs, or plants I send out and will not be responsible for the crop.-FRANK HOWARD. 


\section{9 \\ FRANK HOWARD'S}

GENERAL LIST OF

\section{Standard Tested Vegetable Seeds}

PRICES SUBJECT TO CHANGE

"Our Seeds are Northern Grown, None Better at Any Price."

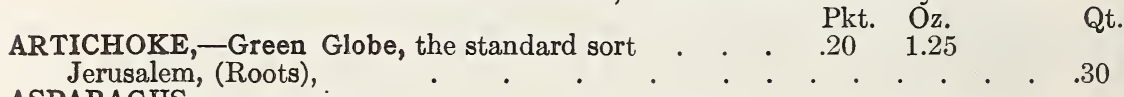
ASPARAGUS,-

Culture.-Sow the seed thinly in rows 1 foot apart in April or May and keep down weeds; thin seedlings to 3 or 4 inches apart. One year old roots should be set out in spring, in rich sandy loam, dug 18 inches deep, work in plenty of well rotted manure. Every fall a good dressing of coarse manure and Quinnipiac or Mapes Fertilizers should be applied after tops are cut and in the spring forked in. Never cut closely.
$\begin{array}{cccc}\text { PALMETTO,-The earliest good yielder, even and } & \text { Pkt. Oz. } 1 / 4 \mathrm{Lb} \text {. } \\ \text { regular in growth, quality unequaled, } & .05 & .050\end{array}$
$\begin{array}{lllllllllll}\text { COLOSSAL, - The old standard variety, } & . & . & . & . & .05 & .10 & .30\end{array}$

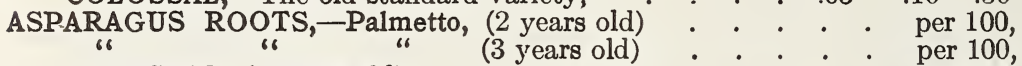
COLOSSAL, (2 years old)

\section{BEANS}

CULTURE.-When ground is perfectly warm and dry, make drill 2 inches deep and 18 inches to 2 feet apart; drop the beans 3 inches apart in the drills, cover not over 2 inches deep. Hoe well in dry weather. Sow every two weeks for succession. Compost, Mapes, or Quinnipiac Fertilizer may be thoroughly worked into soil before planting.

\section{Dwarf Green Podded Varieties} GIANT STRINGLESS GREEN POD,-

Very early, round pods absolutely stringless, fine quality, one of the finest string beans grown, $25 \mathrm{c} 1 / 2 \mathrm{pt}$., $45 \mathrm{c}$ pt., $80 \mathrm{c}$ qt., $\$ 3.001 / 2$ peck.

IMPROVED EARLY RED VALENTINE,-

One of the earliest beans in cultivation. Round pod, 25c 1/2 pt., 45c pt., $80 \mathrm{c}$ qt., $\$ 3.001 / 2$ peck.

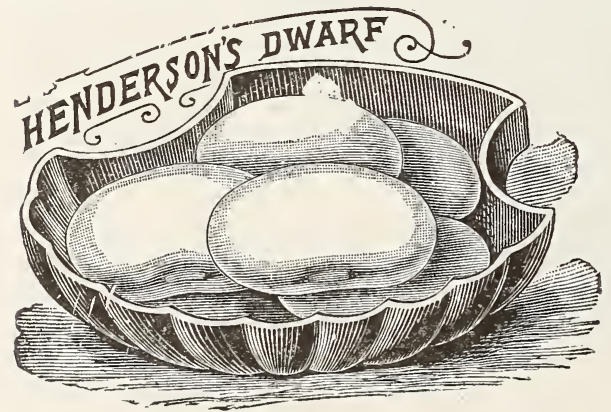

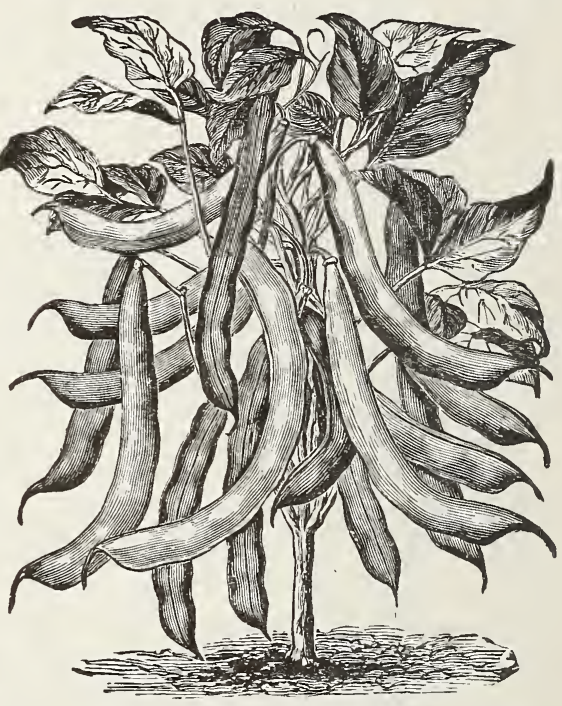

Improved Early Red Valentine

IMPROVED ROYAL WHITE OR KIDNEY,-Excellent for shelling green or baking when ripe, $20 \mathrm{c} 1 / 2 \mathrm{pt}$., $35 \mathrm{c} \mathrm{pt.,}$ $65 \mathrm{c}$ qt., $\$ 2.501 / 2$ peck.

LARGE WHITE MARROW,-The favorite for general field crop, 20c $1 / 2 \mathrm{pt}$., $35 \mathrm{c}$ pt., $65 \mathrm{c}$ qt., $\$ 2.501 / 2$ peck.

HENDERSON'S BUSH LIMA,-The earliest of the Bush Limas, very productive, requires no stakes or poles, quality excellent, 30c $1 / 2$ pt., 50c pt., 90c qt., $\$ 3.251 / 2$ peck. 


\section{BEANS-Continued-Dwarf, Green Podded Varieties}

EXTRA EARLY REFUGEE,-Round pod, very productive, $25 \mathrm{c} 1 / 2 \mathrm{pt} ., 45 \mathrm{c} \mathrm{pt.,} 80 \mathrm{c}$ qt., $\$ 3.001 / 2$ peck.

BOUNTIFUL,-Pods grow to large size, are broad and fleshy, cook tender and fine quality, $25 \mathrm{c} 1 / 2$ pt., $45 \mathrm{c} \mathrm{pt.,} 80 \mathrm{c}$ qt., $\$ 3.001 / 2 \mathrm{pk}$. BURPEE'S STRINGLESS GREEN POD,-

Very early, tender and crisp. Pods pale green, long and straight, round, meaty and stringless, 25c 1/2 pt., $45 \mathrm{c}$ pt., $80 \mathrm{c}$ qt., $\$ 3.25$ $1 / 2$ peck.

BURPEE'S IMPROVED DWARF OR BUSH LIMA,- A perfect bush form of the true luscious large Lima grows from 18 to 20 inches high, stout, and erect growth, immense yielder, $30 \mathrm{c} 1 / 2$ pt., $50 \mathrm{c}$ pt., $90 \mathrm{c}$ qt., $\$ 3.251 / 2$ peck.

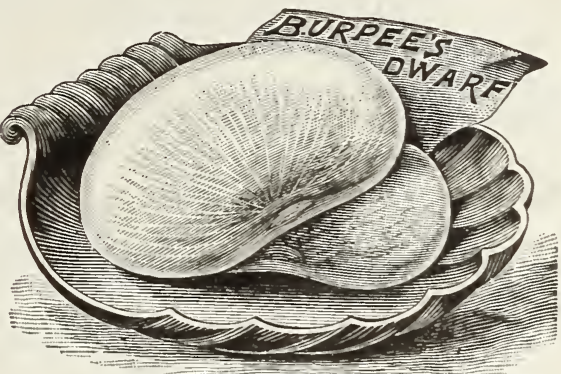

FORDHOOK BUSH LIMA, (New) - Both pods and beans are very large. 30c $1 / 2$ pt., $50 \mathrm{c}$ pt., $90 \mathrm{c}$ qt.

HORTICULTURAL DWARF, or "Dwarf Cranberry," late and productive, flat pod, 25c $1 / 2$ pt., $45 \mathrm{c}$ pt., $80 \mathrm{c}$ qt.: $\$ 3.001 / 2$ peck.

\section{Dwarf, Wax or Butter Varieties}

BLACK WAX, PENCIL POD,--Slender, long, round pods, hardy and prolific, splendid quality, .

$1 / 2$ Pt. Pt. Qt. $1 / 2 \mathrm{Pk}$.

BLACK WAX, IMPROVED,--Probably the original Butter Bean-prolific, tender, early,

IMPRÓVED RUSTLESS GOLDEN WAX,Hardy and productive, pods flat, stringless, wax-like and handsome,

KIDNEY WAX ROUND-POD, (Brittle Wax) -A handsome midseason variety, pods long and round, wax-like, stringless, fine quality

MICHIGAN WHITE WAX,-Early, prolific, very tender, fine quality,

REFUUGEE WAX,--The earliest wax variety, pods very tender, remaining so well through the season, heavy bearer,

$\begin{array}{llll}1 / 2 \mathrm{Pt} . & \text { Pt. } & \text { Qt. } & 1 / 2 \mathrm{Pk} . \\ .25 & .45 & .80 & 3.00 \\ .25 & .45 & .80 & 3.00 \\ & & & \\ .25 & .45 & .80 & 3.00 \\ .25 & .45 & .80 & 3.00\end{array}$

\section{Climbing or Pole Varieties}

CULTURE.-Sow after danger from frost and soil is warm and dry in hills 4 feet each way. Poles 8 or 10 feet long, should be firmly set in hills before planting seed.

GOLDEN CLUSTER WAX,-IMPROVED,

Pods 6 to 8 inches long, golden yellow,

flavor delicious, bears early, and lasts until

$1 / 2$ Pt. Pt. Qt. $1 / 2 \mathrm{Pk}$.

late in the season,

HORTICULTURAL OR CRANBERRY,-A popular variety for shelling,

$\begin{array}{llll}.25 & .45 & .80 & 3.00\end{array}$

$.25 \quad .45 \quad .80 \quad 3.00$

EARLY JERSEY LIMA,--Fully two weeks earlier than the large Lima, and combines quality, quantity and earliness, $\begin{array}{llll}25 & .45 & .50 & \$ 3.00\end{array}$

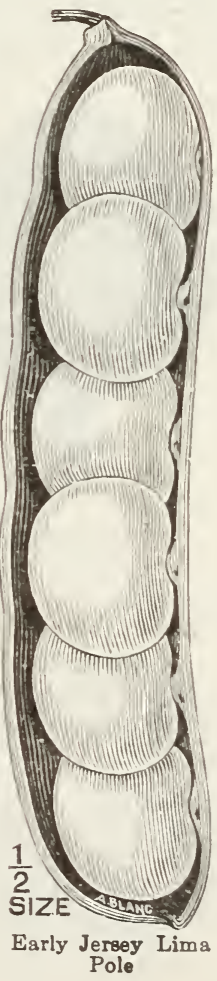


"'Our Seeds are Northern Grown, None Better at Any Price."

\section{BEANS-Climbing or Pole Varieties-Continued}

$1 / 2 \mathrm{Pt}$. Pt. Qt. $1 / 2 \mathrm{Pk}$

$\begin{array}{llllllllllllll}\text { DREER'S LIMA, -Thick, fine quality, } & . & . & . & . & . & .25 & .45 & .80 & \$ 3.00\end{array}$

KING OF THE GARDEN LIMA,-Heavy cropper, bean and pod

very large,

$\begin{array}{llll}.25 & .45 \quad .80 & 3.00\end{array}$

EXTRA LARGE WHITE LIMA,-Extra large size, very tender and delicious,

$\begin{array}{llll}.25 & .45 & .80 & 3.00\end{array}$

DUTCH CASE KNIFE,-Pods long, green and flat, an excellent shell bean,

SCARLET RUNNERS,-Grown principally for ornament, scarlet blossom,

WHITE DUTCH RUNNERS, - Same habit as the scarlet, blossoms white,

OLD HOMESTEAD, (Kentucky Wonder)-Probably the earliest of the green podded pole varieties, enormously productive, tender and nice,

\section{BEETS-Table Varieties}

CULTURE.-Sow as early as the ground can be worked and every two weeks after, up to the first week of July for a succession. For general crop sow after middle of May. Sow in drills, 1 foot to $15 \mathrm{in}$. apart, and when well up thin from 4 to 6 in. Soil should be light, sandy loam, well enriched-very little danger of getting too rich.

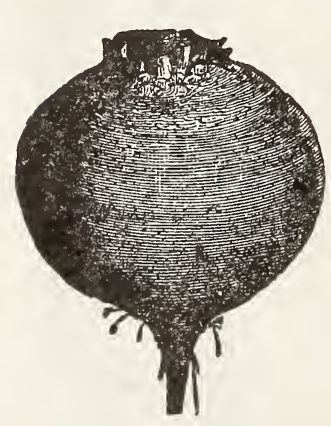

Early Blood Turnip Beet
BASSANO,--Early flat,-An early, tender variety, color light,

BASTIAN'S EARLY BLOOD TURNIP,A good variety to follow Egyptian and Eclipse,

CROSBY EGYPTIAN BEET,-An improvement on the original Egyptian, fully as early and a better keeper,

CRIMSON GLOBE,-Selected. Rich deep crimson, fine quality tender and sweet, globe shaped,

DETROIT DARK RED TURNIP-Round, skin dark blood-red, flesh bright red, .05

DEWING'S BLOOD TURNIP-Fine form and flavor, deep blood-red,
Pkt. Oz. $1 / 4 \mathrm{Lb}$. Lb. $\begin{array}{llll}.05 & .20 & .60 & \$ 2.00\end{array}$ $\begin{array}{llll}.05 & .20 & .60 & 2.00\end{array}$ $\begin{array}{llll}.05 & .25 & .75 & 2.50\end{array}$ $\begin{array}{llll}.05 & .25 & .75 & 2.50\end{array}$ $\begin{array}{llll}05 & .25 & .75 & 2.50\end{array}$ $\begin{array}{llll}.05 & .25 & .75 & 2.50\end{array}$

EARLY BLOOD TURNIP,--One of the best known and most popular sorts, deep blood-red color, excellent quality,

ECLIPSE BLOOD TURNIP,-Very early, one of the best, color bright red,

EDMANDS' BLOOD TURNIP,--Second early, dark red, smooth, round,

LENTZ BLOOD TURNIP,-Very early, small top, round, dark red, .05

SWISS CHARD OR SEA KALE BEET,-Grown exclusively for its leaves. The middle of the leaf can be used and served like asparagus, the rest like spinach, 


\section{"Our Seeds are Northern Grown, None Better at Any Price."}

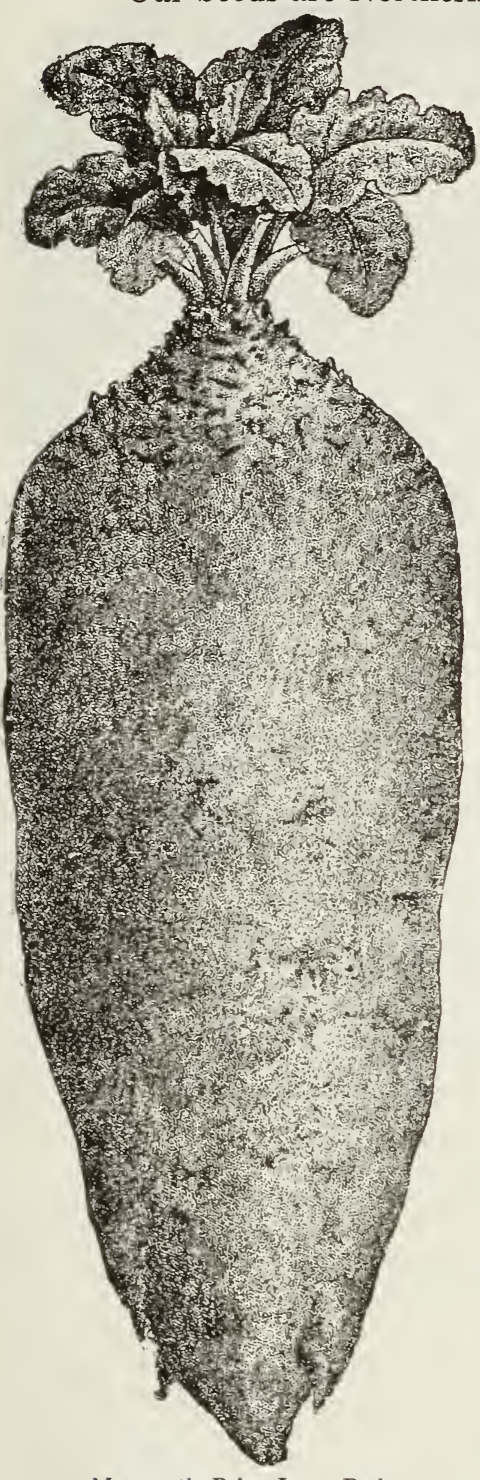

Nammoth Prize Long Red

\section{MANGEL WURZEL}

CULTURE.-Mangels require deep soil to grow well. Plow and subsoil at least a foot to 18 in. Apply plenty of rich stable manure or Mapes or Quinnipiac Fertilizers. Sow latter part of May or in June ( 5 to $8 \mathrm{lbs}$. to acre), in rows not less than 18 inches apart and thin to 8 inches in the row. Young plants may be transplanted to fill up vacancies. When plants are 3 to 4 inches high sow $600 \mathrm{lbs}$. Quinnipiac or Mapes fertilizer to the acre. Cultivate and hoe well, keeping down weeds.

MAMMOTH PRIZE LONG RED,

-One of the best for deep soil, roots very large, very heavy cropper,

Oz. $1 / 4 \mathrm{Lb}$. Lb.

CHAMPION YELLOW GLOBE, -Good keeper, smooth, globe shaped roots,

$.20 \quad .60 \quad 1.65$

$.20 \quad .60 \quad 1.65$

GOLDEN TANKARD, - Flesh bright yellow, said to contain a large amount of sugar,

$.20 \quad .60 \quad 1.65$

NORBITON GIANT,-The largest variety grown, and one of the most popular,

$.20 \quad .60 \quad 1.65$

LANE'S IMPERIAL SUGAR,White fleshed, said to contain a large amount of sugar,

$.20 \quad .60 \quad 1.65$

\section{BROCCOLI}

WHITE CAPE,-(Cultivation same

Pkt. Oz. as Cauliflower) one of the most certain to head, heads compact, creamy white,

\section{BRUSSELS SPROUTS}

\section{(Cultivation same as Cabbage.)}

IMPROVED DWARF,-Compact

heads, probably the best,

.10

.50

\section{CAULIFLOWER}

CULTURE.-Same as cabbage except that an extra amount of fertilizer and plenty of water may be used to advantage.

EARLY SNOWBALL,-The best cauliflower grown, a sure header,

EXTRA EARLY PARIS,-A standard variety,

EARLY FAVORITE,-An excellent very early

Pkt. Oz. variety,

$.25 \$ 6.00$

$.20 \quad 2.00$

$.25 \quad 3.00$

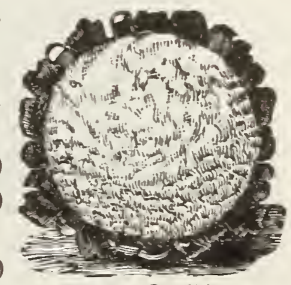

Snowball Cauliflower 


\section{CABBAGE}

CUITTURE. - Soil for Cabbage should be rich, heavy loam, with good drainage. Use an abundance of stable Mapes or Quinnipiac Fertilizers, worked well into the soil. Sow in hot beds, transplanting in the spring as soon as the ground can be worked, $2 \mathrm{ft}$. apart one way and 12 to 18 in. the other, according to variety. For late crops, sow in May, transplant in July. If desired to cultivate with horse, set in rows of $2 \mathrm{ft}$. by $3 \mathrm{ft}$.

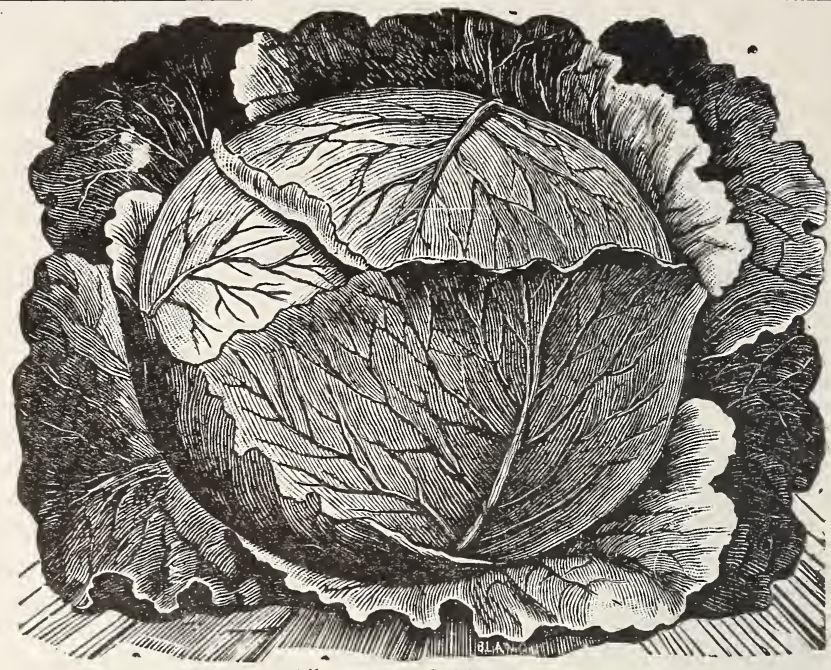

All Seasons Cabbage

ALL HEAD,-Very early and very solid, 10c pkt., 85c 0z., \$3.001/4 lb.

ALL SEASONS, - Fine strain. Heads deep. Can be planted for early or late crop, 10c pkt., $85 \mathrm{c}$ oz., $\$ 3.001 / 4 \mathrm{lb}$.

AUTUMN KING,-One of the finest of late cabbages, excellent keeper, 10c pkt., 85c oz., $\$ 3.001 / 4 \mathrm{lb}$.

CHARLESTON LARGE WAKEFIELD,-About one week later than the Early Jersey Wakefield, but fully one half larger, $10 \mathrm{c}$ pkt., $\$ 1.00 \mathrm{oz} ., \$ 3.501 / 4 \mathrm{lb}$.

EXCELSIOR LATE FLAT DUTCH,-A valuable late variety, one of the best for main

winter crop, $10 \mathrm{c}$ pkt., $85 \mathrm{c}$ oz., $\$ 3.001 / 4 \mathrm{lb}$.

FOTTLER'S IMPROVED BRUNSWICK, -Fine large head, early, planted late makes excellent winter variety, ... .10

IMPROVED EARLY SUMMER,-Ten days later than JerseyWake-

field, large heads, excellent second early,
SUCCESSION IMPROVED,-Ten days later than early Summer, very large, sure header, good keeper and fine quality, ${ }^{\circ}$.

SELECTED EARLY JERSEY WAKEFIELD, - The earliest

cabbage, heads cone shaped and solid,
EARLY WINNINGSTADT, -About three weeks later than Jersey

STONE MASON DRUMHEAD, - Large firm heads, fine quality, late,

Pkt.

Oz. $1 / 4 \mathrm{Lb}$.

DRUMHEAD SAVOY,-Very tender, excellent flavor, fine, •

SUREHEAD IMPROVED, - Large firm heads, late good main crop, .10
HOLLANDER OR DANISH BALL HEAD, -Medium size heads,

$10 \quad .85 \quad 3.00$

$.85 \quad 3.00$

$\begin{array}{lll}10 & .85 & 3.00\end{array}$

$\begin{array}{lll}10 & .85 & 3.00\end{array}$

$\begin{array}{lll}10 & .85 & 3.00\end{array}$ solid, best keeping cabbage grown,

CARRÓTS

$.85 \quad 3.00$

$.85 \quad 3.00$

$.85 \quad 3.00$

$.85 \quad 3.00$

$1.25 \quad 4.50$

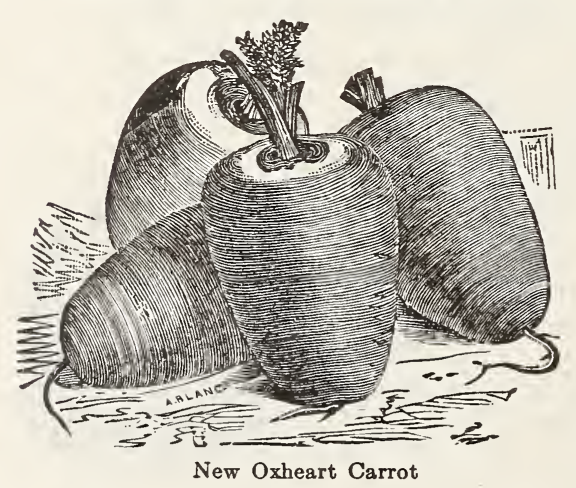

CULTURE.-Sow from middle of May to first of July, in rows 10 in. apart for early, and 14 for main erop, or further apart if it is desired to cultivate with horse. Thin out to 5 in. in rows for early crop, 6 to 7 in. for main crop. Soil, light, sandy loam deeply dug, richly manured, hoe often, cultivate deep.

OXHEART OR GUERANDE,-Roots, short and very thick, intermediate between Scarlet Horn and Half Long, 5c pkt., 25c oz., $85 \mathrm{c} 1 / 4 \mathrm{lb}$., $\$ 2.75 \mathrm{lb}$.

DANVERS' HALF LONG,-(Pointed), heavy yielder, roots 8 to 10 inches long, thick, dark orange, $5 \mathrm{c}$ pkt., $25 \mathrm{c}$ oz., $85 \mathrm{c} 1 / 4 \mathrm{lb}$., $\$ 2.75 \mathrm{lb}$. 


\section{CARROTS-(Continued)}

DANVER'S HALF LONG,-(Stump rooted), similar to above excepting that it has blunt roots, $5 \mathrm{c}$ pkt., $25 \mathrm{c}$ oz., $85 \mathrm{c} 1 / 4 \mathrm{lb}$., $\$ 2.75 \mathrm{lb}$.

EARLY SCARLET HORN, - An early variety, deep orange, blunt root, 6 to 8 in., 5c pkt., $25 \mathrm{c}$ oz., $85 \mathrm{c} 1 / 4 \mathrm{lb}$., $\$ 2.75 \mathrm{lb}$.

FRENCH FORCING,-Small round root, the earliest variety, $\quad \begin{array}{rrrr}.10 & .30 & 1.00 & \$ 3.50\end{array}$

INTERMEDIATE, - Similar in shape to Danvers pointed, color deep

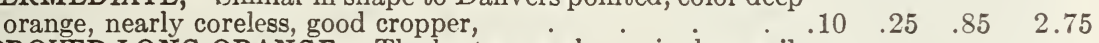

IMPROVED LONG ORANGE, - The best general crop in deep soil,

excellent for stock or table,

$\begin{array}{llll}.05 & .25 & .85 & 2.75\end{array}$

\section{CELERY}

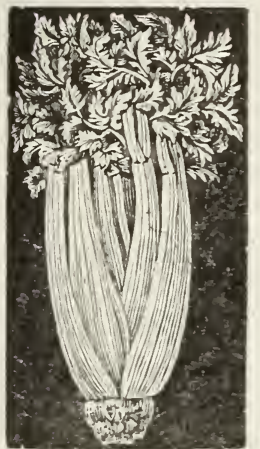

CULTURE.-Sow seeds in light rich soil, as early as ground can be worked, in drills 8 or 10 inches apart, cover seeds about a quarter of an inch deep, rolling or treading them if ground is dry. When fairly out of seed leaf transplant or thin from 6 to 8 inches apart in the row, and let grow until wanted to plant out. Keep well wet down in dry weather. Set out in July, 6 to 8 inches apart, (press soil firmly against roots), in single row in shallow trenches, having previously worked a good quantity of well rotted manure in bottom of trench. It is well to work thoroughly into the soil under and around the trench a quantity of Mapes or Quinnipiac Fertilizers. To raise good celery requires rich soil. Earth up two or three times, taking care not to let the earth get into the heart of the plant.

IMPROVED WHITE PLUME,-One of the easiest to raise as it requires no "banking up." Early and Pkt. Oz. $1 / 4 \mathrm{Lb}$. $\begin{array}{llllllllllllll} & \text { attractive, } & . & . & . & . & .60 & \$ 2.00\end{array}$

DWARF GOLDEN HEART, - Very solid golden yellow heart, excellent keeper, fine flavor,

DWARF GOLDEN SELF BLANCHING,-One of the best early, solid, fine nutty flavor, good size, golden yellow,

$.10 \quad .50 \quad 1.50$

GIANT PASCAL, - The largest variety grown, fine nutty flavor, excellent keeper easily blanched,

201.504 .50 BOSTON MARKET, - Very popular, a strong grower, tender and crisp, $\quad .10 \quad .40 \quad 1.25$ SOUP CELERY,-(Old seed for flavoring), . . . $10 \mathrm{c} \mathrm{oz}$., 20c $1 / 4 \mathrm{lb}$., $60 \mathrm{c} \mathrm{lb}$.

\section{CELERIAC-(Turnip-Rooted Celery)}

CULTURE.-Similar to celery but needs no hilling up.

LARGE SMOOTH PRAGUE,-An improved variety, round, smooth roots, the largest and best variety, $10 \mathrm{c}$ pkt., $50 \mathrm{c} \mathrm{oz} ., \$ 1.501 / 4 \mathrm{lb}$.

CULTURE.-Same as parsley.

\section{CHERVIL}

CURLED,-The leaves are used for flavoring, $5 \mathrm{c}$ pkt., $20 \mathrm{c}$ oz., $50 \mathrm{c} 1 / 4 \mathrm{lb}$.

\section{CHICORY}

CULTURE.- Sow in June, transplant in autumn into sand in cellar.

LARGE ROOTED,-10c pkt., $50 \mathrm{c}$ oz., $\$ 1.501 / 4 \mathrm{lb}$.,

WITLOOF,-Known as French Endive. Sow in May or June in drills. Thin to 6 inches, treat as Endive until end of summer, when it should be banked like Celery. The blanched stalks are used as a salad. It is also used as a boiled vegetable; prepare as cauliflower. 10c pkt., 50c oz., $\$ 1.501 / 4 \mathrm{lb}$.

\section{CORN SALAD OR FETTICUS}

CULTURE.-Sow in August in drills $1 / 4$ in. deep, 6 in. apart, keep down weeds. Just before winter cover thinly with straw or leaves.

LARGE GREEN CABBAGING,-A small, hardy, salad, used also as a substitute for lettuce, 10c pkt., 30c oz., $\$ 1.001 / 4 \mathrm{lb}$. 


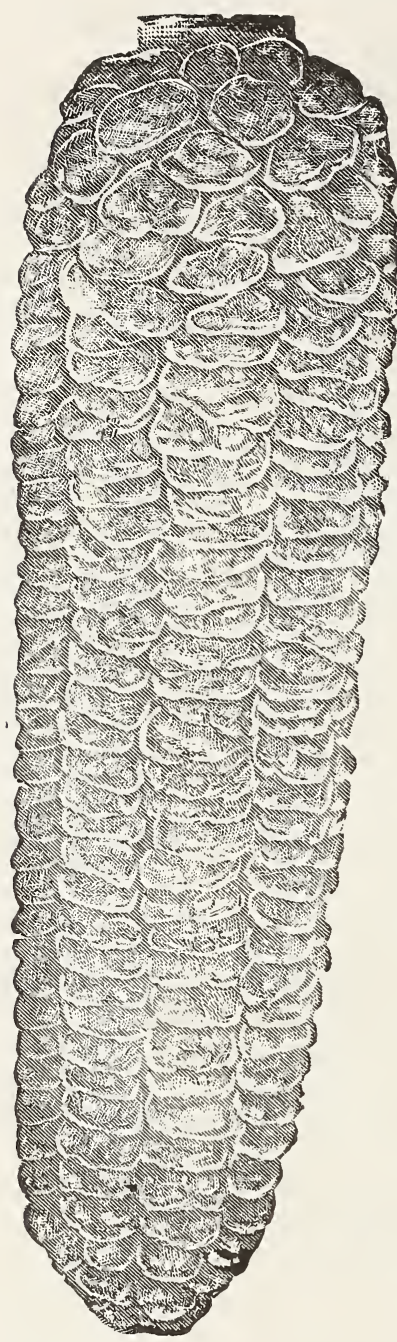

\section{CORN-(Sweet or Sugar)}

CULTURE.-Plant in hills $3 \mathrm{ft}$. apart each way, and five or six kernels in a hill. Hoe often, drawing soil up to stem after first hoeing. Break off side shoots. Make ground very rich. If stable manure is used, it is perhaps best to plow it under. Use broadcast or in the hill Mapes or Quinnipiac Fertilizer, worked well into soil. It has been found very beneficial to sow these fertilizers between the rows before cultivating and hoeing the second time.

We have been very careful in selecting the best and sweetest varieties of corn adapted to this section. The list below is arranged in order as they would mature. If two or more varieties are selected and planted at same time, they would be ready for the table at different times, one following the other.

GOLDEN BANTAM,-Small yellow ears, delicious flavor, $1 / 2$ Pt. Pt. Qt. $1 / 2 \mathrm{Pk}$. MAMMOTH WHITE CORY,-An improvement in size and quality over the white Cory,

HOWARD'S PERFECTION-This

is a new variety coming just after the Cory, large ear, white kernels, and white cob, excellent quality,

CROSBY EARLY,-An old and popular variety, rather small ears, good quality,

MINNESOTA EARLY, - Very early and desirable, ears fair size, good quality,

SHAKER EARLY, - Large ears, excellent quality,

BLACK MEXICAN, - Medium early, black kernels,

POTTER'S EXCELSIOR,-Fine large ears, very sweet, deep grain, medium early,

COUNTRY GENTLEMAN, -A distinct variety, rather small ear, cob very small, but of delicious quality (late),

STOWELL'S EVERGREEN,-The standard for quality, and the best known variety, remains a long time in suitable condition for boiling,

\section{ENSILAGE OR FODDER CORN}

GOLDEN BEAUTY,-An excellent ensilage corn, large growth. Produces an abundance of large ears, resembles the Leaming, but is earlier which is an advantage in Berkshire County and vicinity.

EUREKA,--A very large growing variety with an abundance of leaves.

LEAMING, - The popular corn for ensilage, very well known, similar to the Golden Beauty, but not quite so early.

WEST BRANCH,- - An early, large growing variety, new in this section. It promises to be a winner. 


\section{FIELD CORN}

CULTURE.-Same as Sweet Corn. Some prefer to plant in drills. Use "Quinnipiac" or "Mapes" Fertilizer, worked well into the soil when planting and before second hoeing.

EIGHT ROW YELLOW,-From selected ears grown in this vicinity. Price 25c qt., $\$ 1.50$ peck, $\$ 5.50$ bu.

TWELVE ROW YELLOW,-From selected ears grown in this vicinity. Price $25 \mathrm{c}$ qt., $\$ 1.50$ peck, $\$ 5.50$ bu.

\section{POP CORN}

RICE, - Shelled,-selected for seed, RICE,- - " - for popping,

Per lb.,

Per lb.,
$20 \mathrm{c}$

$10 \mathrm{c}$ to $15 \mathrm{c}$

\section{CRESS OR PEPPER GRASS}

CULTURE.-Sow curled variety thickly in shallow drills every two or three weeks. Cut often. Sow water cress in damp soil or along streams of water.

EXTRA CURLED,-Used as salad, Pkt. Oz. $1 / 4 \mathrm{Lb}$. Lb. TRUE WATER CRESS,-Grows along the

banks of ponds and streams - a fine salad, $\begin{array}{llll}.05 & .15 & .45 & 1.50\end{array}$

$.10 \quad .853 .00$

\section{CUCUMBERS}

CULTURE.-For very early, sow seeds in hotbeds upon pieces of sod. Transplant when danger from frost is over. For general crop, sow in open ground when danger from frost is over and again every two weeks for a succession. For pickles sow from middle of June, to first week in July. Plant in hills $4 \mathrm{ft}$. apart, making hills rich. TELEGRAPH,-For growing in hotbeds or greenhouses, Pkt., 25c BOSTON PICKLING, - One of the best for pickling, 5c pkt., 20c o\%.,

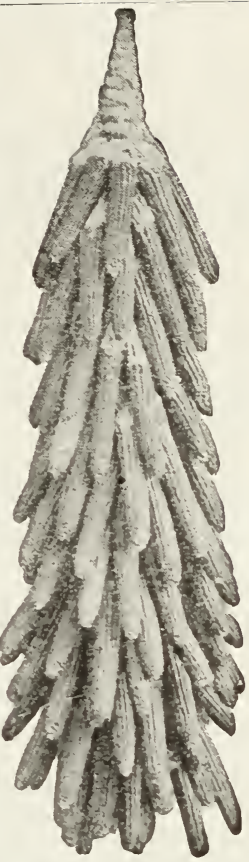

$60 \mathrm{c} 1 / 4 \mathrm{lb}$., $\$ 1.50 \mathrm{lb}$.

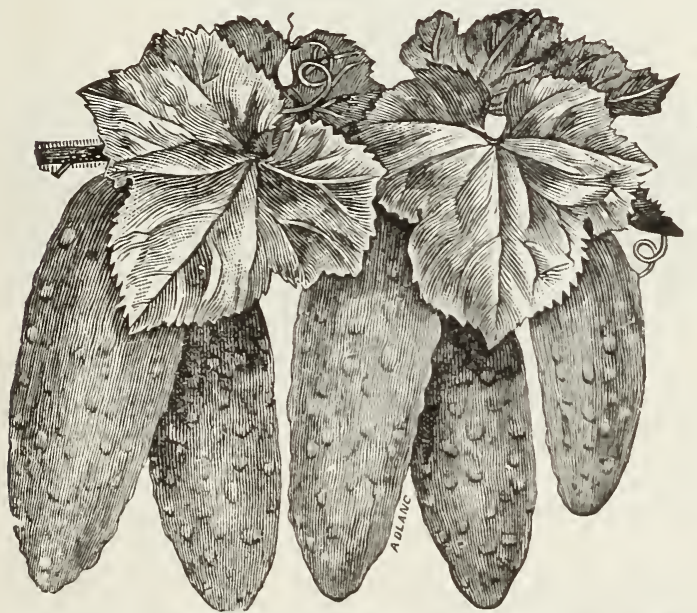

COOL AND CRISP,-New, very desirable for both pickling and slicing, $5 \mathrm{c}$ pkt., $20 \mathrm{c}$ oz., $60 \mathrm{c} 1 / 4 \mathrm{lb}$., $1.50 \mathrm{lb}$.

EARLY CLUSTER, -A popular variety, grows in pairs, $5 \mathrm{c}$ pkt., $20 \mathrm{c}$ oz., $60 \mathrm{c} 1 / 4 \mathrm{lb}$., $1.50 \mathrm{lb}$.

JAPANESE CLIMBING,-Good for frames or open ground, 10c pkt., 20c oz., 65c 1/4 lb., $\$ 2.00 \mathrm{lb}$.

FORDHOOK PICKLING,-Very prolific, medium size, fine pickling strain, 5c pkt., 20c oz., 60c $1 / 4$ lb., $\$ 1.75 \mathrm{lb}$.

EARLY FRAME,-Early, good for pickling, and slicing, $5 \mathrm{c}$ pkt., $20 \mathrm{c}$ oz., $60 \mathrm{c} 1 / 4 \mathrm{lb}$., $\$ 1.50 \mathrm{lb}$.

IMPROVED LONG GREEN,-The favorite for general crop, good pickler or slicer, 5c pkt., 20c oz., $60 \mathrm{c} 1 / 4 \mathrm{lb} ., \$ 1.50 \mathrm{lb}$.

NICHOL'S MEDIUM GREEN,--Intermediate between Long Green and Frame, 5c pkt., $20 \mathrm{c}$ oz., $60 \mathrm{c} 1 / 4 \mathrm{lb}$. . $\$ 1.50 \mathrm{lb}$.

SNOW'S PERFECTED PICKLE,-Excellent pickling cucumber, 5c pkt., 20c oz., 60c 1/4 lb., $\$ 1.50 \mathrm{lb}$

IMPROVED WHITE SPINE, One of the popular varieties, early, vigorous grower, crisp is and fine flavor, $5 \mathrm{c}$ pkt., $20 \mathrm{c}$ oz., $60 \mathrm{c} 1 / 4 \mathrm{lb}$., $\$ 1.50 \mathrm{lb}$.

\section{DANDELION}

CULTURE.-Sow in early Spring in drills 1-2 in. deep and 18 in. apart, thin plants to 12 in. Keep clear of weeds. The leaves will be ready to cut the following spring.They are best if blanched, which can be done by placing two boards edgewise over the row.

IMPROVED THICK LEAVED, - Very much superior to the commion dandelion for greens.

20 c per pkt., $\$ 1.00 \mathrm{oz}$. 
"Our Seeds are Northern Grown, None Better at Any Price."

\section{EGG PLANT}

CULTURE. - Sow in hot beds very early in spring, transplant when 2 in. high into second bed or small pots, or thin to 4 in. apart. Plant out after weather is perfectly settled and warm. Set plants 3 feet by 2 feet.

NEW YORK IMPROVED SPINELESS,-The earliest and probably the best, $15 \mathrm{c} \mathrm{per} \mathrm{pkt.,}$

$85 \mathrm{c}$ per oz., $\$ 2.75$ per $1 / 4 \mathrm{lb}$.

\section{ENDIVE}

CULTURE.-Sow in June, July or August, cover lightly, thin to 8 in. apart. Water well if dry. When leaves are 6 or 8 in. blanch by tying together near top; at approach of winter, take up with a ball of earth and put in cool dry cellar. Handling of plants must be done when perfectly dry.

GREEN CURLED,-The popular variety, one of the best salads for fall and winter use,

$5 \mathrm{c}$ pkt., $25 \mathrm{c}$ oz., $70 \mathrm{c} 1 / 4 \mathrm{lb}$.

MOSS CURLED,- -5c pkt., $25 \mathrm{c}$ oz., $70 \mathrm{c} 1 / 4 \mathrm{lb}$.

BROAD LEAVED,-A sweet variety; fall or winter, $5 \mathrm{c}$ pkt., $25 \mathrm{c}$ oz., $70 \mathrm{c} 1 / 4 \mathrm{lb}$.

WHITE CURLED,-For early use, 5c pkt., 25c oz., $70 \mathrm{c} 1 / 4 \mathrm{lb}$.

\section{GOURDS}

FANCY VARIETY MIXED,-5c pkt., 30c oz.

CULTURE.-Same as cabbage.

\section{Kale or Borecole}

DWARF GREEN CURLED SCOTCH,-Grown for winter greens, 10c pkt., 40c oz., $\$ 1.251 / 4$ lb., $\$ 4.00 \mathrm{lb}$.

\section{KOHL RABBI-or Turnip-Rooted Cabbage}

CULTURE.-Sow in Spring in rows 18 in. apart, thin to 8 or 10 in., when thickened stems are 2 or 3 in. through above ground they are ready to eat and should be used at once. Cook same as turnips.

PURPLE VIENNA, -10c pkt., 35c oz., $\$ 1.001 / 4 \mathrm{lb}$.

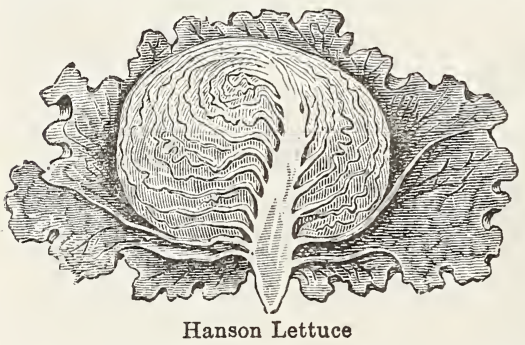

Hanson Lettuce

\section{LETTUCE}

CULTURE.-Sow in hot beds, and in open ground as soon as it can be worked. sow again in 2 weeks for succession. Transplant in rows 8 in. apart. Cos should be started very early in hot beds, and to blanch should be tied. Lettuce requires very rich ground well pulverized, in fact lettuce to be tender and crisp should have rapid growth, otherwise it will be tough and probably bitter.

BIG BOSTON,-About twice the size and one week later than The

Pkt. Oz. $1 / 4 \mathrm{Lb}$. Boston Market, produces large solid heads,

BOSTON MARKET,-Edges slightly tinged with red, good forcing or out-door variety,

$.05 \quad .20 \quad .60$

$.05 \quad .20 \quad .60$

GRAND RAPIDS,-One of the best forcing varieties, strong grower, curly, tender, crisp and retains its freshness a long time after being cut,

GOLDEN QUEEN,-Medium size golden yellow, solid heads, early,

HANSON IMPROVED, - Outer leaves green, inner white, sure header, excellent quality, very satisfactory,

IMMENSITY, - The largest head lettuce, not early, but reliable for late summer and fall use,

MAY KING,-Large, round, solid heads, outer leaves yellowish green, tinged with brown, inside rich, golden yellow, early,

NEW YORK CABBAGE, - Not a forcing variety but one of the best summer lettuces, forms large heads, inside white,

PHILADELPHIA BUTTER, - Inner leaves yellow, heads solid,

PRIZE HEAD, - Leaves green and red, thin, crisp and tender,

SALAMANDER,-Heads compact, resists summer heat admirably, light green outside, white inside,

SILESIA EARLY CURLED,-Early and tender, leaves yellowish green,

$\begin{array}{lll}.05 & .20 & .60 \\ .05 & .30 & .85 \\ & & \\ .05 & .20 & .60 \\ & & \\ .05 & .20 & .60 \\ & & \\ .05 & .20 & .60 \\ & & \\ .05 & .20 & .60 \\ .05 & .20 & .60 \\ .05 & .20 & .60 \\ & & .60 \\ .05 & .20 & .60 \\ .05 & .20 & .60\end{array}$




\section{LETTUCE-(Continued)}

SIMPSON BLACK SEEDED,-Leaves yellow, good for forcing or sowing out of doors,

SIMPSON EARLY CURLED,-Good for forcing or open ground sowing, yellowish green,

TENNIS BALL, BLACK SEEDED,-Forms handsome hard head, crisp and tender.

TENNIS BALL, WHITE SEEDED,-Excellent forcing variety, head firm, white and crisp,

TRIANON COS OR ROMAINE,-Self-closing, an excellent variety, bleaches white, very crisp and tender,

WHITE PARIS COS,-Has long narrow leaves, does not head, but when tied up blanches very nicely,

Pkt. Oz. $1 / 4 \mathrm{Lb}$.

$\begin{array}{lll}.05 & .20 & .60\end{array}$

$\begin{array}{lll}.05 & .20 & .60\end{array}$

$.05 \quad .20 \quad .60$

$.05 \quad .20 \quad .60$

$.05 \quad .20 \quad .60$

$.05 \quad .20 \quad .60$

\section{LEEK}

CULTURE.-Sow very early in drills 6 inches apart and 1 ineh deep. Thin to 1 inch. When 7 inches high, transplant in rows 12 inches apart, deep as possible without covering center leaves. Water well if dry when planted out. Draw soil up to them as they grow. Rich soil is necessary.

BROAD AMERICAN FLAG, -By far the best variety grown, $10 \mathrm{c}$ pkt., $50 \mathrm{c}$ oz., $\$ 1.501 / 4 \mathrm{lb}$.

\section{MUSK MELON}

CULTURE.-Light, sandy soil, very rich, plant when ground is dry and warm, in hills from 4 to 6 feet apart each way, 10 or 12 seeds to a hill. When well up and danger from insects is past, thin to 3 or 4 plants to hill. Pinch ends of growing shoots to induce early fruiting.

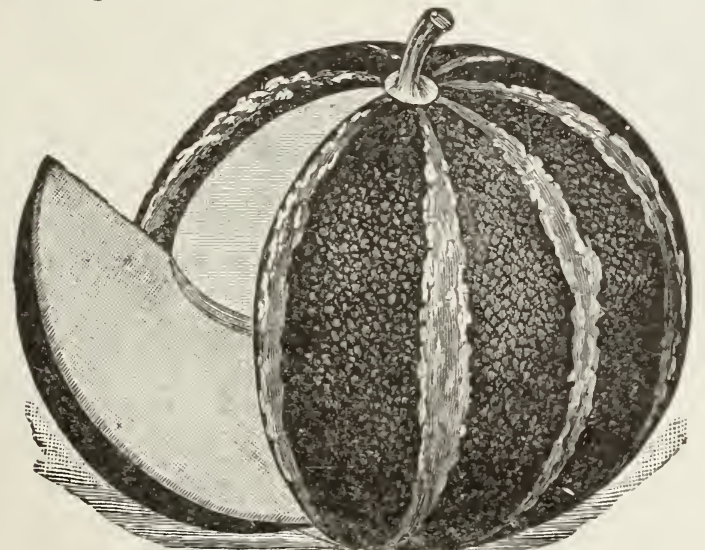

HACKENSACK EXTRA EARLY IMPROVED,-Quality perfect, very early, popular in this section, 5c pkt., 20c oz., $60 \mathrm{c} 1 / 4 \mathrm{lb}$.

EMERALD GEM,-Medium size skin smooth, deep green, flesh salmon, delicious flavor, $5 \mathrm{c}$ pkt., $20 \mathrm{c}$ oz., $60 \mathrm{c} 1 / 4 \mathrm{lb}$.

GOLDEN NETTED GEM Round, very early, delicious, 5c pkt., 20c oz., 60c $1 / 4 \mathrm{lb}$.

MILLER'S CREAM OR OSAGE -Delicious flavor, flesh thick, salmon pink, 5c pkt., $20 \mathrm{c}$ oz., $60 \mathrm{c} 1 / 4 \mathrm{lb}$.

MONTREAL NUTMEG.-Excellent variety, large size, flesh melting and of delicious flavor, $5 \mathrm{c}$ pkt., $20 \mathrm{c}$ oz., $60 \mathrm{c} 1 / 4 \mathrm{lb}$.

ROCKY FORD,-Netted, very sweet and fine flavored, $5 \mathrm{c}$ pkt., $20 \mathrm{c}$ oz., $60 \mathrm{c} 1 / 4 \mathrm{lb}$.

SURPRISE,-One of the best for this section, flesh deep salmon, thick and fine flavor, $5 \mathrm{c}$ pkt., $20 \mathrm{c}$ oz., $60 \mathrm{c} 1 / 4 \mathrm{lb}$.

\section{WATER MELON}

CULTURE.-Same as Musk Melon, only plant further apart, about 8 or 10 feet PHINNEY'S EARLY, - Very early, fine quality, excellent variety for Pkt. Oz. $1 / 4 \mathrm{Lb}$. this section, $\quad \begin{array}{llll}.05 & .10^{\circ} & .35\end{array}$ MOUNTAIN SWEET, -Early, oblong,dark green, flesh red,solid, sweet, $\quad .05 \quad .10 \quad .35$ CITRON,-Red Seed,-For Preserving,

$.05 \quad .10 \quad .35$

\section{MUSTARD}

CULTURE.-Sow thickly during early spring in shallow drills. Sow early in September for fall salad.

BLACK OR BROWN,-For salads, $5 \mathrm{c}$ pkt., 10c oz., $25 \mathrm{c} 1 / 4 \mathrm{lb} ., 75 \mathrm{c} \mathrm{lb.}$

WHITE LONDON,-For salads, 5c pkt., 10c oz., 
"Our Seeds are Northern Grown, None Better at Any Price."

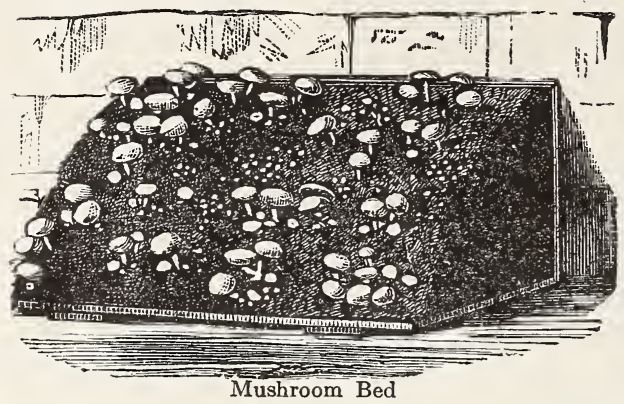

\section{MUSHROOM SPAWN}

CULTURE.-Mushrooms are more easily cultivated than many people imagine and may be grown in any room or cellar where the temperature can be maintained at from 50 to 65 degrees. For the beds use a mixture of three parts horse droppings and one part good fresh loam. Before being placed in the bed, let the manure be put in some dry place to sweeten, mixing it thoroughly and turning it three or four times, when the loam may be added. Upon a dry firm bottom or shelf, make the bed by spreading a thin layer of the prepared mixture, pounding it firm, and continue this, till the bed is twelve inches thick. Leave it thus for about a week, or until the temperature has subsided to 85 degrees. Then make holes about ten inches apart, and put in each a piece of spawn about the size of an egg. Press the spawn firmly into the compost about two inches, leaving the top uncovered to allow the excess of heat and moisture to pass off without injury to the germs. After ten days, fill the holes and cover the whole bed with two inches of fresh loam, and over this place a few inches of straw. If the temperature is right, mushrooms will appear in six or eight weeks from the time of spawning. The bed will continue bearing from four to six weeks. If the surface of the bed becomes dry at any time, it should be moistened freely with water at a temperature of 90 to 100 degrees.

Our stock of spawn is replaced a number of times during the season and is giving excellent results.

AMERICAN,-In bricks, per brick 30c. 10 bricks $\$ 2.75$.

ENGLISH,- “ " " " $25 \mathrm{c} \quad 10$ " 2.25 .

\section{NASTURTIUM-(See Flower Seed) OKRA OR GUMBO}

CULTURE.-Sow late in Spring when ground is warm, in drills $3 \mathrm{ft}$. apart, thin from 9 to 12 in. They should be well manured.

DWARF WHITE VELVET,--Pods round, smooth and white, very prolific, DWARF GREEN,-Very early,

Pkt. Oz. 1/4Lb. Lb.

$\begin{array}{llll}.05 & .10 & .25 & .75\end{array}$

$\begin{array}{llll}.05 & .10 & .25 & .75\end{array}$

\section{ONIONS}

CULTURE.-Sow in rich light soil in drills $1 \mathrm{ft}$. apart (or wider if to be cultivated with horse). Hoe or rake frequently to keep down weeds. Use Mapes or Quinnipiac Fertilizers.

YELLOW GLOBE DANVERS-Our Finest Strain.

This seed is grown from the very earliest, and best selected Onions, and is very much superior to the average seed offered.-The Yellow Globe Danvers is the standard variety, good yielder, excellent keeper, $10 \mathrm{c}$ pkt., $50 \mathrm{c}$ oz., $\$ 1.75 \mathrm{1} / 4 \mathrm{lb}$., $\$ 5.00 \mathrm{lb}$.

YELLOW GLOBE DANVERS,-Fine Strain,-While this is not equal to our finest strain, it is fully equal to most onion seed, and the same that is usually sold by dealers, 10c pkt., 50c oz., $\$ 1.501 / 4 \mathrm{lb} ., \$ 4.50 \mathrm{lb}$.

EXTRA EARLY FLAT RED,-Very early, medium size, mild, $10 \mathrm{c}$ pkt., $50 \mathrm{c}$ oz., $\$ 1.75 \mathrm{l} / 4 \mathrm{lb} ., \$ 5.00 \mathrm{lb}$.

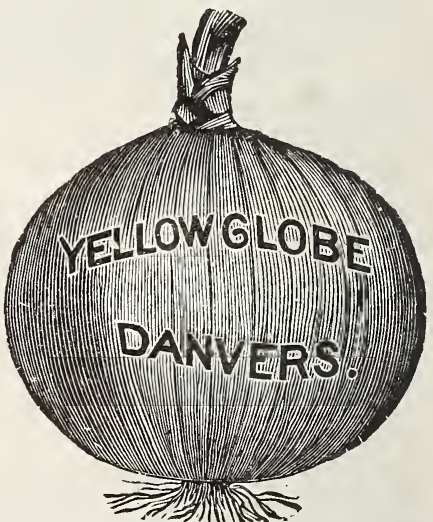

NEW QUEEN,--Rapid grower, mild flavor, flat, white, fine for pickling, 10c pkt., 60c oz., $\$ 1.851 / 4 \mathrm{lb} ., \$ 6.00 \mathrm{lb}$. 
" Our Seeds are Northern Grown, None Better at Any Price."

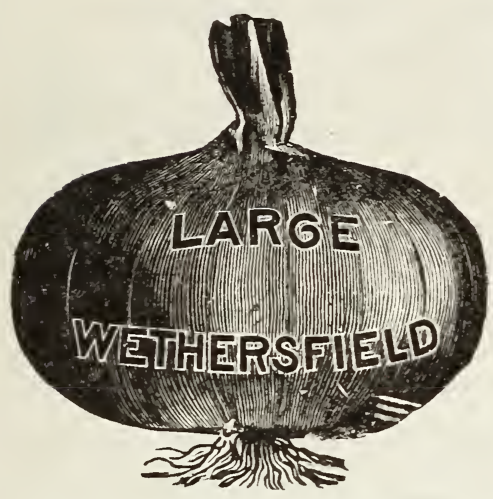

ONION SEED

LARGE RED WETHERSFIELD,-Large yielder, good keeper, $10 \mathrm{c}$ pkt., $50 \mathrm{c} \mathrm{oz} ., \$ 1.501 / 4 \mathrm{lb} ., \$ 4.50 \mathrm{lb}$.

PRIZETAKER,-Bulbs very large, uniform, very productive, flavor mild, color, bright straw, choice American stock, 10c pkt., 60c oz., \$1.85 1/4 lb., $\$ 6.00 \mathrm{lb}$.

WHITE PICKLING,-The best for pickling, $10 \mathrm{c}$ pkt., 60c oz., \$1.85 1/4 lb., \$6.00 lb.

SOUTHPORT WHITE GLOBE,-Large, firm, fine, grained, mild flavor, $10 \mathrm{c}$ pkt., $60 \mathrm{c} \mathrm{oz}$., $\$ 1.851 / 4 \mathrm{lb}$., $\$ 6.00 \mathrm{lb}$.

SOUTHPORT YELLOW GLOBE,-Same as White except in color, 10c pkt., 50 o oz., \$1.65 1/4 lb., \$5.00 lb.

WHITE PORTUGAL OR SILVERSKIN,-A flat white onion, fine grained, good keeper, 10c pkt., $60 \mathrm{c}$ oz., $\$ 1.85 \mathrm{l} / 4 \mathrm{lb}$., $\$ 6.00 \mathrm{lb}$.

HOWARD'S EXTRA EARLY RED GLOBE,-Ten days earlier than Southport Red Globe, color beautiful bright red, $10 \mathrm{c}$ pkt., $50 \mathrm{c}$ oz., $\$ 1.75 \mathrm{l} / 4 \mathrm{lb}$., $\$ 5.00 \mathrm{lb}$.

\section{ONION SETS}

White, price sub-

Qt. $1 / 2 \mathrm{Pk}$. Pk. Bu. ject to change, $.35 \$ 1.30 \$ 2.50 \$ 9.50$ Yellow, price subject to change, $.30 \$ 1.10 \$ 2.10 \$ \$ .00$

\section{PARSLEY}

CULTURE-Soak seed a few hours in warm water, sow early, and until the middle of July in drills $1 \mathrm{ft}$. apart. Thin to 4 in. For winter use, transplant to light cellar.

CHAMPION MOSS CURLED,-Beautifully crimped and curled, 5c pkt., $15 \mathrm{c}$ oz., $50 \mathrm{c} 1 / 4 \mathrm{lb}$., $\$ 1.50 \mathrm{lb}$.

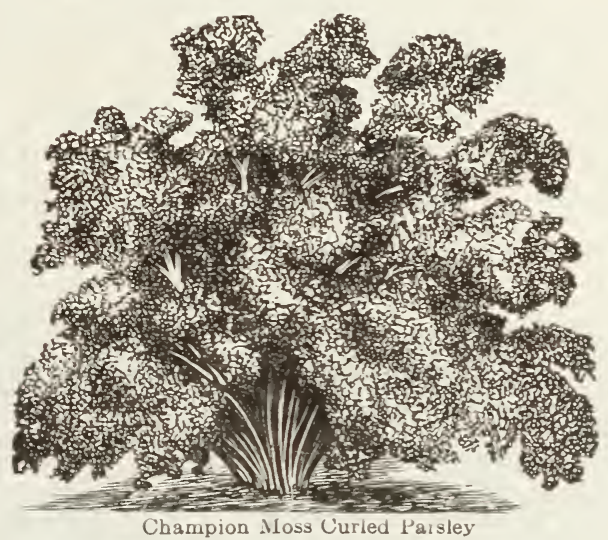

FINE DOUBLE CURLED,-A standard variety, finely curled leaves, $5 \mathrm{c}$ pkt., $15 \mathrm{c}$ oz., $50 \mathrm{c}$ $1 / 4 \mathrm{lb} ., \$ 1.50 \mathrm{lb}$.

FERN LEAVED,-Has a feathery, fern-like appearance, 5c pkt., $15 \mathrm{c}$ oz., 50c 1/4 lb., \$1.50 lb.

\section{PARSNIP}

CULTURE.-Sow in drills 18 in. apart as soon as ground can be worked in Spring in rich soil, well and deeply dug. Thin to 6 or $\delta$ in. Keep weeds down.

LONG SMOOTH WHITE,-Standard variety, long, smooth, white roots,

HOLLOW CROWNED, -An excellent variety, fine quality,

STUDENT,-Fine strain, with long smooth roots,

Pkt. Oz. 1/4lb. Lb.

$\begin{array}{llll}.05 & .25 & .70 & 2.25\end{array}$

$\begin{array}{llll}.05 & .25 & .70 & 2.25\end{array}$

$\begin{array}{llll}.05 & .25 & .70 & 2.25\end{array}$

\section{PEAS}

CULTURE.-For Peas, light dry soil is best. Sow as early as ground can be worked, and again every ten days for succession. Peas may be sown as late as August 15th. Medium and late Peas must be planted early. Early Peas may be planted early or late, and the extra early very late. Sow in single or double rows from 4 to 6 feet apart, according to variety, and about an inch apart in the row and $4 \mathrm{in}$. deep. Hoe often, keep ground clean and fine. Most Dwarf Peas will bear better if bushed enough to keep them from the ground. If the pea louse attacks the vines, spray every day with clear water of the san.e temperature as the atmosphere. using force. 
"Our Seeds are Northern Grown, None Better at Any Price."

\section{PEAS-(Continued)-Extra Early Dwarf Varieties}

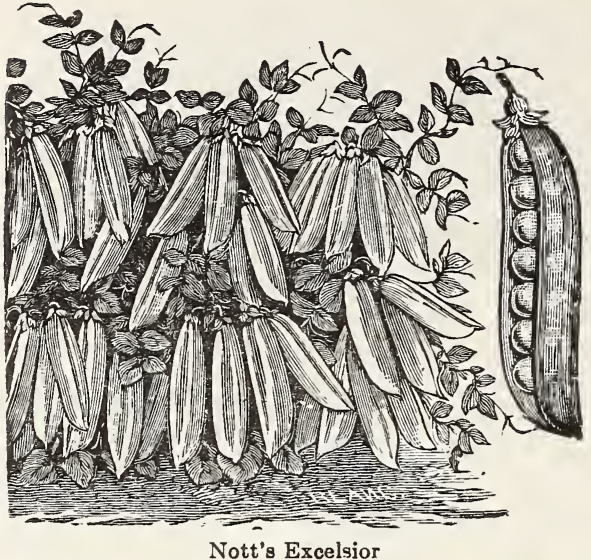

*Those marked with a star (*) are wrinkled peas and unless otherwise stated, should be sown thicker than the round Peas.

${ }^{*}$ B L I S S

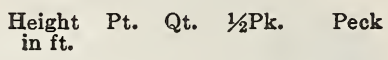
AMERICAN WONDER,Fine quality $\begin{array}{llllll}\text { very early, } & 1 & .40 & .70 & \$ 2.50 & 4.50\end{array}$ *PREMIUM GEM-An improvement on Little Gem fine variety, $\quad 1 \frac{11 / 4}{4} \quad .40 \quad .70 \$ 2.50 \quad 4.50$

*LITTLE MARVEL,-A little earlier than the Wonder, good quality, remarkably prolific,

*LAXTONIAN, - Very large, dark green, curved pods and Peas of finest flavor, good yielder, very early,

*NOTT'S EXCELSIOR,-Fine quality, very early, good yielder,

*SUTTON'S EXCELSIOR-Similar to Nott's larger pods,

$\begin{array}{lllll}11 / 4 & .40 \quad 70 & \$ 2.50 \quad 4.50\end{array}$

$\begin{array}{lllll}11 / 2 & .40 \quad .70 & \$ 2.50 \quad 4.50\end{array}$

$11 / 4 \quad .40 \quad .70 \quad \$ 2.50 \quad 4.50$

$\begin{array}{lllll}1 & .40 & .70 & \$ 2.50 & 4.50\end{array}$

\section{Extra Early Varieties-Not Dwarf}

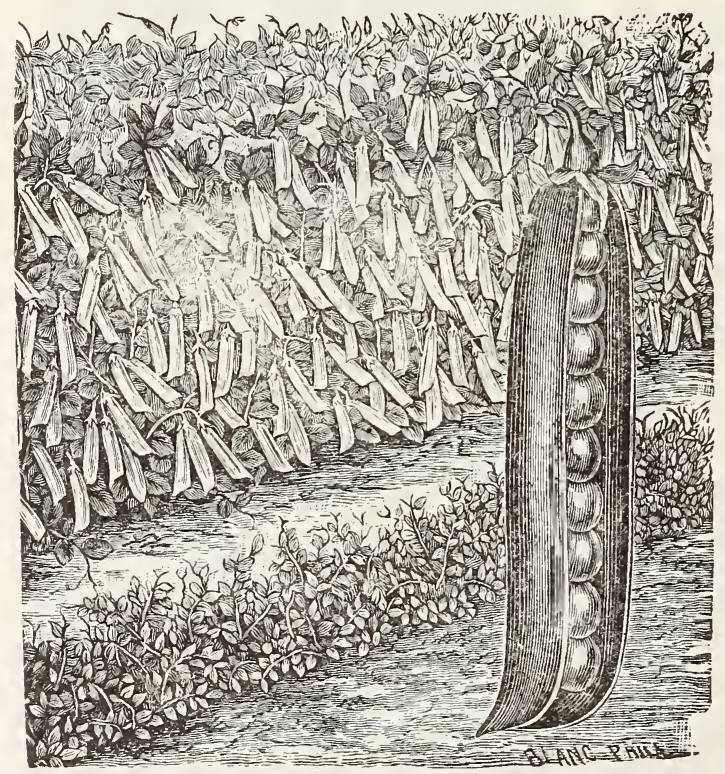

ALASKA,-The earliest blue pea, fine sort, hardy and productive,

*GRADUS,--(Prosperity),-One of the finest extra early peas yet introduced. It is in condition to pick about five days after our Extra Early, pods large, well filled with wrinkled deep green peas,

\section{HOWARD'S}

\section{EXTRA EARLY}

One of the very earliest peas grown, ripens evenly, pods well filled, in quality and productiveness it is fully equal to any of the early smooth sorts, height 2 1-4 feet, pint $40 \mathrm{c}$., quart, $70 \mathrm{c}$, $1 / 2$ pk. $\$ 2.50$, peck $\$ 4.50$.

Height in ft. Pt. Qt. 1/2Pl. Peck $\begin{array}{lllll}21 / 2 & .35 & .60 & \$ 2.00 & 3.75\end{array}$

$\begin{array}{lllll}3 & .40 & .70 & \$ 2.50 & 4.50\end{array}$ 
"Our Seeds are Northern Grown, None Better at Any Price."

\section{PEAS-(Continued)-Extra Early Varieties}

*THOMAS LAXTON,-Very early and productive,
pods large, finest flavor,

Height in feet Pt. Qt. $1 / 2 \mathrm{Pk}$. Pk

PHILADELPHIA EXTRA EARLY,-

FIRST AND BEST,-A standard early variety,

IMPROVED DAN'L O'ROURKE, - A reliable early sort,
3

$21 / 2$

$21 / 2$

$21 / 2$ $\begin{array}{llll}.40 & .70 & \$ 2.50 & 4.50\end{array}$

$\begin{array}{llll}.40 & .70 & \$ 2.50 & 4.50\end{array}$

$\begin{array}{llll}.40 & .70 & \$ 2.50 & 4.50\end{array}$

$\begin{array}{llll}.40 & .70 & \$ 2.50 & 4.50\end{array}$

\section{Second Early Varieties}

*EVERBEARING,--Remains long time in bearing, peas large, pods long, fine flavor,

*NEW DWARF CHAMPION,-Very productive, large peas, delicious flavor,

$21 / 2$

$.35 \quad .60$

$2.00 \quad 3.75$

*HORSFORD'S MARKET GARDEN,-On the style of Advancer, peas sweet and delicious,

*MCLEAN'S ADVANCER,-A fine and popular variety,

2

$.35 \quad .60$

$2.00 \quad 3.75$

$.35 \quad .60$

$2.00 \quad 3.75$

$.35 \quad .60$

$2.00 \quad 3.75$

\section{Tall Late Varieties}

*ALDERMAN,-(New) Extra large pods on order of Duke of Albany, very fine,

4

AMERICAN CHAMPION (DUKE OF ALBANY), -

A trifle earlier than the Champion of England, fine variety, should be sown thinly,

*CHAMPION OF ENGLAND,-One of the richest, best flavored peas, well known and popular, 5

*IMPROVED TELEPHONE, - Very fine strain, pods very large, well filled, quality excellent, 4

CANADA FIELD,-Principally sown for feeding stock, market price,

BLACKEYED MARROWFAT,-An old-time favorite, 5

SUGAR, MAMMOTH MELTING,-Edible pods, 4

$\begin{array}{llll}.40 & .70 & 2.50 & 4.50 \\ .40 & .70 & 2.50 & 4.50 \\ .40 & .70 & 2.50 & 4.50 \\ .40 & .70 & 2.50 & 4.50 \\ & & & \\ .25 & .45 & 1.50 & 2.50 \\ .30 & .50 & & \end{array}$

\section{PEPPERS}

CULTURE.-Sow in hotbeds in March, when soil is warm, set in rows $2 \mathrm{ft}$. and $18 \mathrm{in}$. in the row. Hoe frequently.

\section{LARGE BELL OR BULL NOSE,-A} favorite, large, mild, red,

$\mathrm{Pk} . \mathrm{Oz} \cdot 1 / 4 \mathrm{Lb}$.

LONG RED CAYENNE,-Small, long, bright, red, extremely strong,

CHINESE GIANT,--Very large, flesh mild and thick, bright scarlet,

$\begin{array}{lll}.10 & .85 & 2.50\end{array}$

$.10 \quad .65 \quad 2.25$

.101 .00

RUBY KING,-Mild, very large and handsome,

SWEET MOUNTAIN,-Large and mild, a popular sort,

.101 .00

$\begin{array}{lll}.10 & .85 & 2.50\end{array}$

RED CHERRY,-Cherry-shaped, for pickles, 


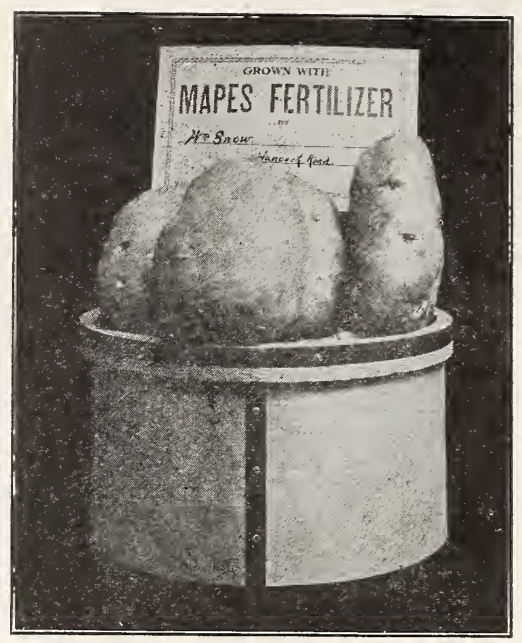

\section{POTATOES}

CULTURE.-So many conflicting opinions exist as to the best method of growing potatoes, that we do not venture to give directions for culture. We do, however, make the following suggestions: Plant in such a manner that most of the heavy hard work can be done by the horse. Use "Mapes Potato Manure," or "Quinnipiac Potato or Market Garden," in sufficient quantities to insure a crop. Always bear in mind that to get the full benefit of the fertilizer and not burn the roots it should be thoroughly mixed with the soil. If stable manure is used at all, it should not come in contact with the tubers, as it is sure to make the crop rough and scabby.

These Potatoes were raised from our Maine Grown Seed, the crop was uniform and heavy and of excellent quality.

\section{POTATOES}

Use the "Quinnipiac or Mapes Fertilizers." To insure quantity and quality in your potato crop there are positively no better fertilizers made.

\section{Early Potatoes}

The Potatoes we offer were grown and harvested in Maine especially for seed purposes.

BEAUTY OF HEBRON,-An excellent and popular early variety,

$1 / 2 \mathrm{Pk} . \mathrm{Pk}, \quad 165 \mathrm{lb}$

EARLY DEW DROP,-New, fine quality, early white variety, good yielders,

EARLY ROSE, -A well known early variety,

IRISH COBBLER, - Fine quality, white, vigorous growth,

QUEEN,--Early, productive, fine quality,

$.45 \quad .85 \$ 2.85 \quad 7.00$

$\begin{array}{llll}.55 & 1.00 & 3.50 & 8.00\end{array}$

$\begin{array}{llll}.45 & .85 & 2.85 & 7.00\end{array}$

$\begin{array}{llll}.45 & .85 & 2.85 & 7.00\end{array}$

$\begin{array}{llll}.45 & .85 & 2.85 & 7.00\end{array}$

\section{INTERIMEDIATE and LATE VARIETIES}

CARMEN NO. 3,-Heavy yielder, fine quality,

$.45 \quad .85 \$ 2.85 \quad 7.00$

NORCROSS,-Late, white, oval potato, good quality, good main

crop,

$\begin{array}{llll}.45 & .85 & 2.85 & 7.00\end{array}$

GREEN MOUNTAIN,-—Oval, white, excellent, heavy yielder,

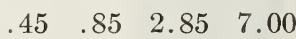

\section{PUIMPKINS}

CULTURE.-Same as for squash, or may be planted with corn.

CONNECTICUT FIELD, - The popular one for general crop, 'usually grown in corn fields for stock,

Pt. Qt. Pk.

$.20 \quad .35 \quad \$ 2.00$

Pkt. Oz. $1 / 4 \mathrm{Lb}$.

KING OF THE MAMMOTHS,-Grows very large, round, flat, yellow $\quad .10 \quad .20 \quad .60$

SWEET CR SUGAR, - Small, round, yellow, excellent for pies,

$.05 \quad .15 \quad .50$


“Our Seeds are Northern Grown, None Better at Any Price."

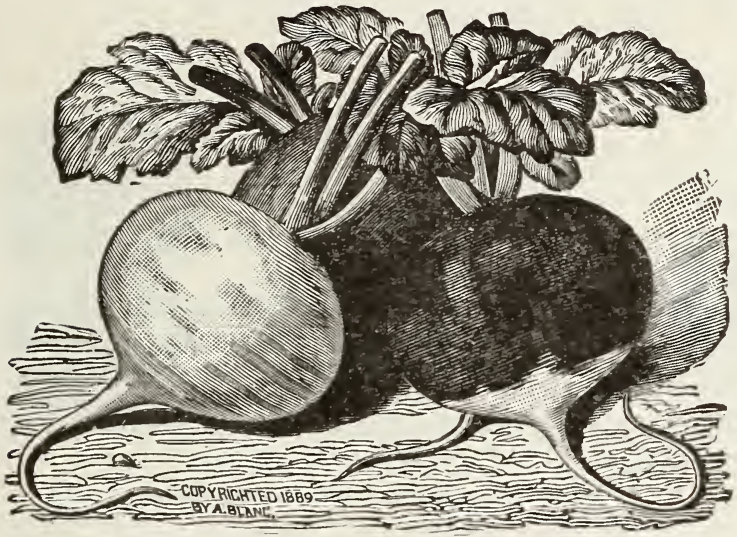

\section{RADISH}

CULTURE.-Sow as soon as ground is dry, in rows 8 to 12 in. apart, and every 10 days after for succession, up to middle of June. Light, rich soil.

\section{EARLY ROUND DARK RED,-} Early, pleasant flavored, 5c pkt., 20c oz., 60c 1/4 lb., $\$ 2.00 \mathrm{lb}$.

EARLY SCARLET TURNIP,Popular, quick grower, mild flavor, 5c pkt., $20 \mathrm{c}$ oz., $60 \mathrm{c} 1 / 4$ lb., $\$ 2.00 \mathrm{lb}$.

SCARLET TURNIP, WHITE TIPPED,-Very early, fine quality, $5 \mathrm{c}$ pkt., $20 \mathrm{c}$ oz., $60 \mathrm{c}$ $1 / 4 \mathrm{lb}$., $\$ 2.00 \mathrm{lb}$.

OLIVE SHAPED SCARLET,-Early, flesh firm and crisp, 5c pkt., 20c oz., 60c 1/41b., $\$ 2.00 \mathrm{lb}$.

ROSY GEM,-Globe-shaped, deep scarlet on top blending to white on the bottom, very fine,

FRENCH BREAKFAST, -Olive-shaped, white-tipped, popular,

Pkt. Oz. $1 / 4 \mathrm{Lb}$. Lb.

SCARLET GLOBE, - One of the earliest, good for forcing or open ground culture, crisp and tender,

LONG SCARLET SHORT TOP,-The old favorite,

CHARTIER,-An excellent long variety, scarlet,

LONG ICICLE,-Pure white, fine flavor,

WHITE LADY FINGER OR VIENNA,-The finest of the long,

white radishes,

WHITE STRASBURG,-Long summer variety of good quality,

$\begin{array}{llll}.05 & .20 & .602 .00\end{array}$

$\begin{array}{llll}05 \quad .20 \quad .60 & 2.00\end{array}$

$\begin{array}{llll}05 \quad .20 \quad .60 & 2.00\end{array}$

$05 \quad .20 \quad .60 \quad 2.00$

$\begin{array}{llll}05 & .20 & .50 & 1.75\end{array}$

$\begin{array}{llll}05 & .20 & .50 & 1.75\end{array}$

$\begin{array}{llll}05 & .20 & .50 & 1.75\end{array}$

$\begin{array}{llll}05 & .20 & .50 & 1.75\end{array}$

\section{Winter Radishes}

ROUND BLACK SPANISH, -Skin black, globe-shaped, tender, $\quad .05 \quad .20 \quad .50 \$ 1.50$ LONG WHITE SPANISH,-Skin white, mild,

$\begin{array}{llll}05 & .20 & .50 & 1.50\end{array}$

ROSE CHINA WINTER,-Rose-colored skin, flesh white, quality

excellent,

$\begin{array}{llll}05 & .20 & .50 & 1.50\end{array}$

\section{RHUBARB}

CULTURE.-Sow seed in March in cold frame, keep from freezing, transplant to open ground in about 8 weeks, in rows 12 in. apart each way. The following spring transplant to 4 or 5 feet apart each way. Ground should be very rich. Cover in fall with thick dressing of coarse manure, spade under in the spring.

VICTORIA, - A popular variety, 10c pkt., $25 \mathrm{c}$ oz., $75 \mathrm{c} 1 / 4 \mathrm{lb}$.

ROOTS, -Each 25c, $\$ 2.00 \mathrm{doz}$.

\section{SALSIFY OR VEGETABLE OYSTER}

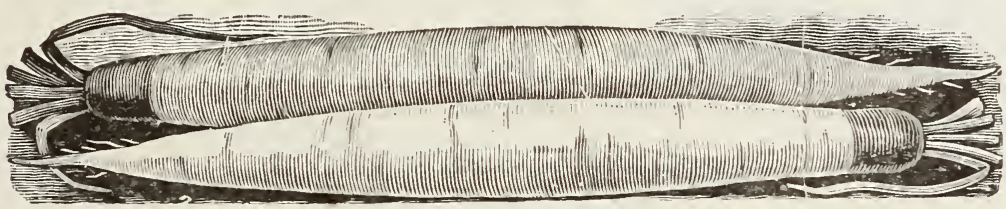

CULTURE.-Sow as early as ground can be worked in spring, in drills 12 in. apart, 1 in. deep. Thin to 6 in. in row. Cultivate and treat as parsnips.

MAMMOTH SANDWICH ISLAND,-The best variety, 10c pkt., 30c oz., $\$ 1.00 \frac{1}{4} / \mathrm{lb} ., \$ 3.50 \mathrm{lb}$. 
"Our Seeds are Northern Grown, None Better at Any Price."

\section{SPINACH}

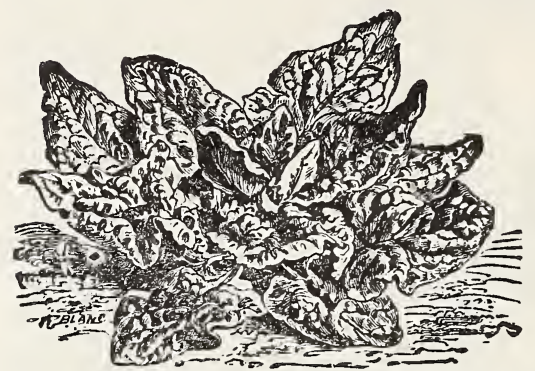

CULTURE,-Sow early in spring in drills one ft. apart. As it grows, thin out for use. For fall use sow in August. Sow New Zealand in hills two feet apart each way, three or four seeds in hill. This is fit for cutting all summer.

BLOOMSDALE SAVOY LEAVED,-Crinkled leaves, hardy, fine quality, $5 \mathrm{c}$ pkt., $15 \mathrm{c}$ oz., $50 \mathrm{c} 1 / 4 \mathrm{lb}$., $\$ 1.75 \mathrm{lb}$.

LARGE VIROFLAY,-Leaves thick, roundish, heavy cropper, $5 \mathrm{c}$ pkt., $15 \mathrm{c}$ oz., $50 \mathrm{c} 1 / 4$ lb., $\$ 1.75 \mathrm{lb}$.

LONG-STANDING THICK-LEAVED,-Dark green, stands a long time before going to seed, 5c pkt., $15 \mathrm{c}$ oz., 50c $1 / 4$ lb., $\$ 1.75 \mathrm{lb}$.

NEW ZEALAND,-Should be started and transplanted, grows

Pkt. Oz. 1/4Lb. Lb. well during the hot weather. Seed should be soaked in hot water before sowing,

THICK-LEAVED ROUND,-One of the best, leaves large, thick, crumpled,

PRICKLY WINTER,-

$.1025 . \quad .85 \$ 2.50$

\section{SQUASH-Summer Varieties}

CULTURE.-Sow in hills same time and manner as cucumbers and melons, the bush varieties 3 to 4 feet and running 6 to 9 feet.

WHITE BUSH SCALLOP,-Very early, Pkt. Oz. 1/4Lb. Lb. good shipper,

YELLOW BUSH SCALLOPED,-Same as

above, excepting color,

$\begin{array}{lll}.05 & .25 \quad .75 \quad 2.00\end{array}$

GIANT SUMI variety, The favorite summer $\begin{array}{llll}.05 & 25 & .75 & 2.00\end{array}$ VEGETABLE MARROW,-Summer and fall variety, outside yellow, flesh white, $\quad .05 \quad .25 \quad .75$

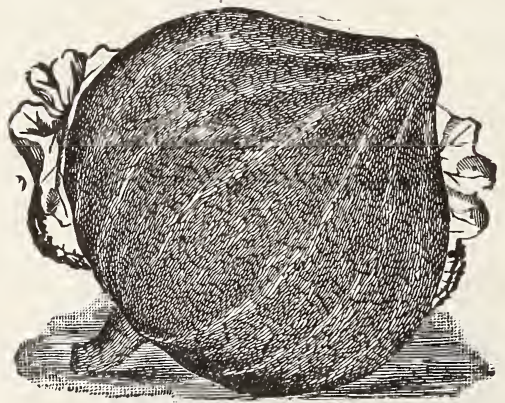

\section{Fall and Winter Varieties}

BOSTON MARROW,-Fine

fall variety, oval, bright orange,

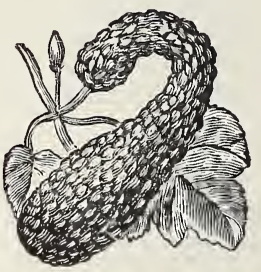

DELICIOUS, - Green skin, orange flesh, fine grained, sweet and dry,

IMPROVED HUBBARD,The leading variety, fine, grained, dry, excellent, flavor,

Pkt. Oz. $1 / 4 \mathrm{Lb}$. Lb.

$\begin{array}{llll}.05 & .20 & .60 & 2.00\end{array}$

$\begin{array}{llll}.05 & .25 & .75 & 2.50\end{array}$

IMPROVED MARBLEHEAD, - Similar to Hubbard, a trifle earlier,

$\begin{array}{llll}.05 & .25 & .75 & 2.50\end{array}$

MAMMOTH CHILI,-Orange yellow, grows very large,

$\begin{array}{llll}.05 & .25 & .75 & 2.50\end{array}$

$\begin{array}{llll}.05 & .25 & .75 & 2.50\end{array}$

SUNFLOWER,-See Flower Seeds.

TOBACCO,-Connecticut Seed Leaf, 10c pkt., 50c oz. 


\section{"Our Seeds are Northern Grown, None Better at Any Price."}

\section{TOMATO}

CULTURE.-Sow thinly in March in hotbed or in boxes in the house; when 2 inches high set out plants in boxes, four inches apart or pot singly. If again transplanted before setting in the ground they will be benefited. Plant out about June 1st. Set deeply 4 feet each way. Make hills very rich. Support with frame work or train to stakes.

ACME,-Early, smooth, solid, color purplish red,

Pkt. Oz. $1 / 4 \mathrm{Lb}$.

BEAUTY (Livingston's), - Large, smooth, solid, purplish red,

$.10 \quad .45 \$ 1.50$

CHALK'S EARLY JEWEL,-New, large, solid, smooth, bright red, very early,

$.10 \quad .45 \quad 1.50$

$.10 \quad .50 \quad 1.75$

CORELESS (Livingston's),-Almost round, bright red, very productive, Ripens all over at once, almost free from green core, fine for slicing,

$.10 \quad .50 \quad 1.75$

CRIMSON CUSHION,-Very large, scarlet crimson, few seeds, fine new variety,

DWARF CHAMPION,-Vine compact and upright, very early, smooth, color same as Acme,

EARLIANA, - Extra early, bright red,

FAVORITE, (Livingston's), -Large, smooth, productive, good shipper,

$.10 \quad .752 .50$

$.10 \quad .50 \quad 1.75$

$.10 \quad .50 \quad 1.75$

PERFECTION, (Livingston's),-Early, regular, productive, bloodred, few seeds,

$.10 \quad .451 .50$

$.10 \quad .45 \quad 1.50$

$.10 \quad .75 \quad 2.50$

PONDEROSA,-One of the largest, solid, good flavor, bright red,

RED CHERRY, - Fruit small, about $5 / 8$ inch in diameter, fine for preserves,

$.10 \quad .60$

$.10 \quad .45 \quad 1.50$

$.10 \quad .60$

$.10 \quad .45 \quad 1.50$

YELLOW PLUM,-Plum shaped, deep yellow, fine flavored,

TROPHY, Extrá Selected,-A standard late sort,

\section{TURNIP}

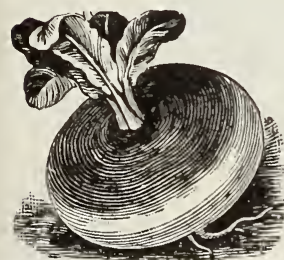

CULTURE.-For early turnips sow as soon as ground can be worked. For fall and early winter sow from middle of July to August. Sow Ruta Bagas in June or early in July in drills 18 in. apart; thin from 6 to 9 inches; soil should be rich and well worked. The early varieties may be sown broadcast, but Ruta Bagas should be sown in drills.

EARLY SNOWBALL, - Round, medium size, fine quality,

Pkt. Oz. $1 / 4$ Lb. Lb.

EARLY WHITE FLAT DUTCH, - Sweet and fine grained,

$.05 \quad .25 \quad .75 \$ 2.50$

$\begin{array}{llll}.05 & .25 & .75 & 2.50\end{array}$

EXTRA EARLY PURPLE TOP MUAN,-The earliest turnip grown, $\quad .05 \quad .25 \quad .752 .50$

LONG WHITE COWHORN,--Roots carrot shaped, flesh firm, white and sweet,

PURPLE TOP STRAP-LEAVED,-The leading variety for sowing broadcast, good for stock or table use,

$.05 \quad .25 \quad .75 \quad 2.50$

$\begin{array}{llll}.05 & .25 & .75 & 2.50\end{array}$

IMPROVED GOLDEN BALL,-An excellent table variety, round, yellow fleshed, sweet and solid,

WHITE EGG,-Good yielder, flesh firm, fine grained and sweet,

YELLOW ABERDEEN,-Flesh pale yellow, tender, fine flavored,

YELLOW GLOBE,-Good for general crop, grows large, good

keeper,

YELLOW STONE,-Good table variety, good keeper,

$.05 \quad .25 \quad .75 \quad 2.50$

$\begin{array}{llll}.05 & .25 & .75 & 2.50\end{array}$

$\begin{array}{llll}.05 & .25 & .75 & 2.50\end{array}$

$\begin{array}{llll}.05 & .25 & .75 & 2.50\end{array}$

$.05 \quad .25 \quad .75 \quad 2.50$ 
"Our Seeds are Northern Grown, None Better at Any Price."

\section{TURNIP-(Continued)-Ruta Baga or Swedish Varieties}

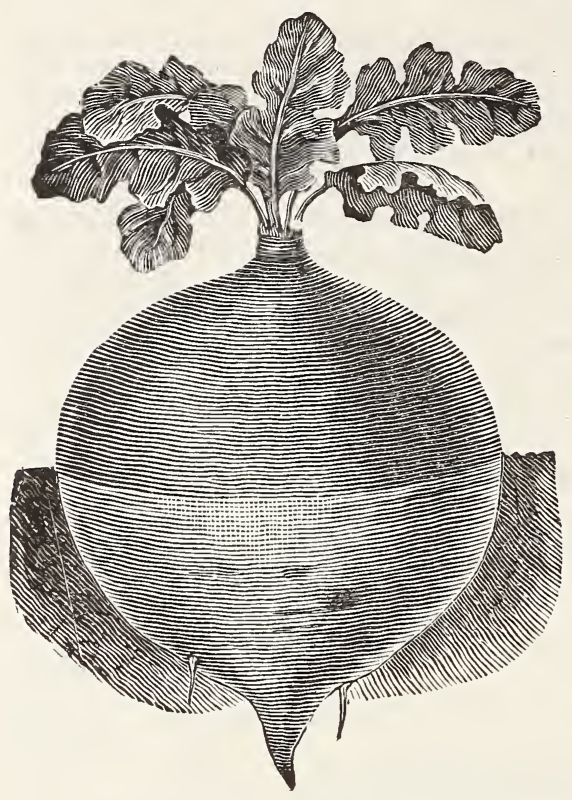

IMPROVED AMERICAN PURPLE TOP,-

The favorite yellow fleshed winter turnip, 10c pkt., 25c oz., 85c 1/4lb., $\$ 2.75 \mathrm{lb}$.

LONG ISLAND PURPLE TOP,-One of the best, flesh yellow, solid, sweet, 10c pkt., 25c oz., 85c 1/4lb., $\$ 2.75 \mathrm{lb}$.

SHAMROCK SWEDE, -An excellent yellow fleshed variety, 10c pkt., 25c oz., 85c 1/4 lb., $\$ 2.75 \mathrm{lb}$.

WHITE SWEDE,-A superior white fleshed variety, $10 \mathrm{c}$ pkt., $25 \mathrm{c}$ oz., $85 \mathrm{c} 1 / 4 \mathrm{lb}$., $\$ 2.75 \mathrm{lb}$.

WHITE SWEET GERMAN,-A fine sweet winter variety, good keeper, 10c pkt., $25 \mathrm{c}$ oz., $85 \mathrm{c} 1 / 4 \mathrm{lb}$., $\$ 2.75 \mathrm{lb}$.

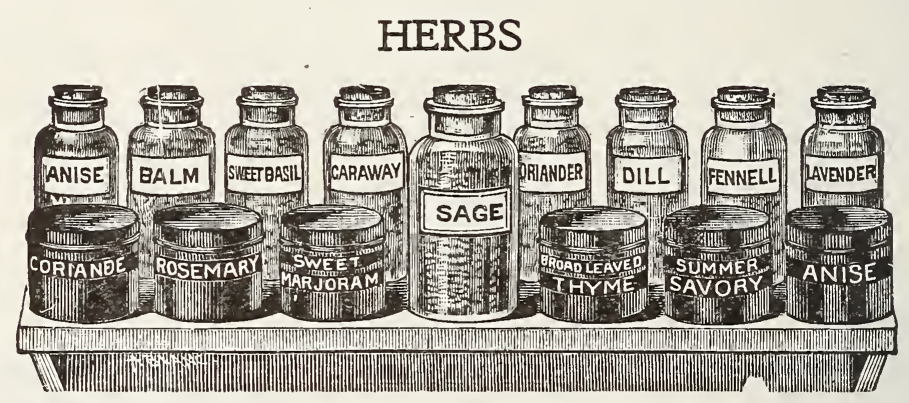

Pkt. $1 \mathrm{Oz}$.

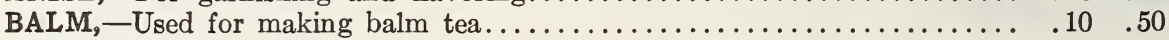

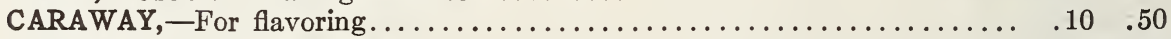

CORIANDER, - For flavoring. . . . . .

DILL, -For flavoring. . . . . . . .

HOREHOUND,-Used for its tonic properties................... $10 \quad .50$

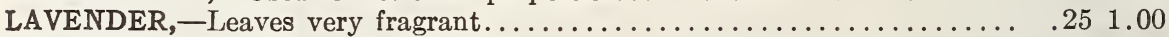

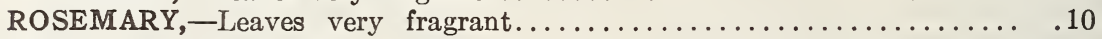

RUE, -Used for medicinal purposes................................ 10

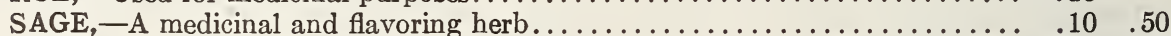

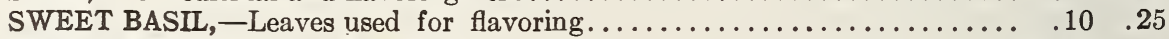

SWEET FENNEL, -Seeds aromatic......................... . 10.20

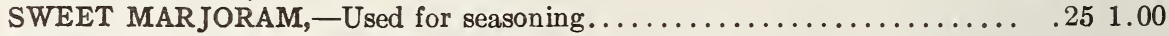

SUMMER SAVORY, -Used for seasoning. . . . . . . . . .

THYME, - Used for seasoning. . . . . . . . .

WORMWOOD,-Used for medicinal purposes................... . 10 .60 
"Our Seeds are Northern Grown, None Better at Any Price." FLOWER SEEDS

STANDARD VARIETIES.

Those marked $\#$ are climbers

ALYSSUM, Sweet, white, very fragrant, annual,

AMARANTHUS - "Joseph's Coat,"-Ornamental foliage plant, easily

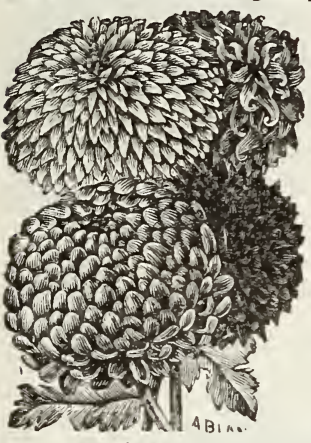
cultivated, very showy, annual, mixed,

ANTIRRHINUM, - "Snap Dragon," - Half hardy perennial. An old favorite border plant, blooms the first season, but the flowers are stronger the second year, grand for cutting,

\section{ASTERS}

One of the most popular and useful of our annuals.

VICTORIA, - Finest Mixed, - Flower very large and double, considered all in all one of the most satisfactory strains of asters

COMET,-Mixed,-Large beautiful flowers, resembling the Japanese Chrysanthemum,

Pkt. Oz.

PERFECTION WHITE,-Large flowers, one of the best of the white asters,

Asters

CHINA,-Mixed Colors,

.15

.05

BALSAM,(Lady Slipper) - Mixed Double-An old favorite summer garden annual, . 10

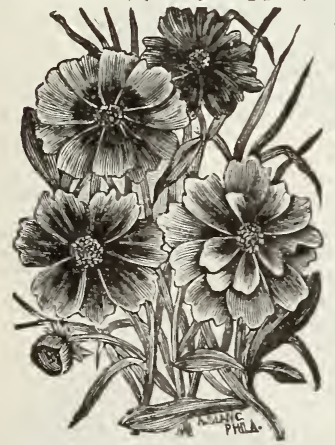

BACHELOR BUTTON,-See Centaurea and Globe Amaranth.

CALLIOPSIS OR COREOPSIS,-Mixed Colors,- Showy summer bedding annuals, producing a profusion of every shade of yellow, orange, crimson, red and brown.

CAMPANULA, - Canterbury Bells, - "Cup and Saucer." The finest variety with white and blue flowers, resembling a cup and saucer, hardy perennial,

CANARYBIRD VINE, - Yellow flower, rapid climber,

CANDYTUFT,-Mixed Annual,-For massing in beds or borders, fine for cutting,

CANDYTUFT, - White-

Calliopsis

CARNATION MARGUERITE,-Finest Mixed,

These beautiful flowers are very fragrant, great favorites, comparatively easy to cultivate,

CARNATION GIANT MARGUERITE,-Finest Mixed,

CASTOR OIL PLANT, - See Ricinus.

CELOSIA OR COCKSCOMB,-Glasgow Prize,-Popular annuals of easiest culture,

CELOSIA,-Mixed,

CENTAUREA, - "Bachelor Buttons," - Mixed, a very old favorite garden annual,

CLARKIA, - Hardy Annual,-Mixed,

\#COBAEA SCANDENS,-Mixed rapid growing climber, flowers large and

bellshaped, plant seeds edgewise, cover lightly,

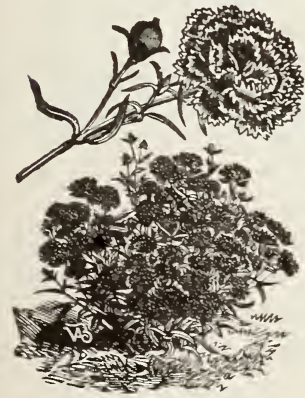

Dianthus Chinensis

COLUMBINE,-Double Mixed.-A most desirable border plant,

\#CONVOLVULUS MAJOR,-Tall Morning Glory. A rapid free flowering climber,

CONVOLVULUS MINOR,-Dwarf Morning, Glory,

COSMOS,-Extra early fancy mixed,-One of the notable fall flowers,

\#CYPRESS VINE,-Mixed,-Summer climbing annual with feathery foliage and star-shaped flowers, borne in clusters,

DIANTHUS, OR PINKS, -

The Dianthus is one of the most beautiful and satisfactory of the garden annuals; they are unrivaled for brilliancy and profusion of bloom.

DIANTHUS CHINENSIS,-China Pink,-Mixed double, 5c pkt. 
"Our Seeds are Northern Grown, None Better at Any Price."

\section{FLOWER SEEDS-(Continued)}

\section{DIANTHUS HEDDEWIGI,-Japan Pink,-}

Mixed Double, 5c pkt.

\#DOLICHOS,-Hyacinth Bean,-Mixed annual climbing plant of rapid growth, $5 \mathrm{c}$ pkt.

ESCHSCHOLTZIA,- "California Poppy",-Mixed single, very attractive for edgings or masses, large handsome flowers of yellow, orange and white, $5 \mathrm{c}$ pkt.

FORGET-ME-NOT,-“Myosotis"-Mixed, bears clusters of lovely small flowers,--hardy perennial, 10c pkt.

FOUR O'CLOCK,-See Marvel of Peru.

GAILLARDIA,-Mixed, exceedingly beautiful annuals, blossoms from early summer until frost, unrivalled for cutting, 5c pkt.

GLOBE AMARANTH,-Mixed, a species of Bachelor Button, very ornamental, a summer blooming plant, 5c pkt.

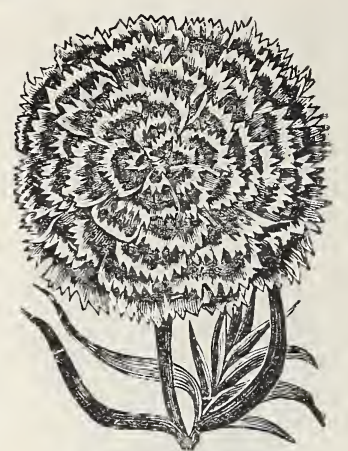

Dianthus Heddewigii

EELIOTROPE, -Finest mixed,-Deliciously fragrant flowering plant, tender perennial, $10 \mathrm{c}$ pkt.

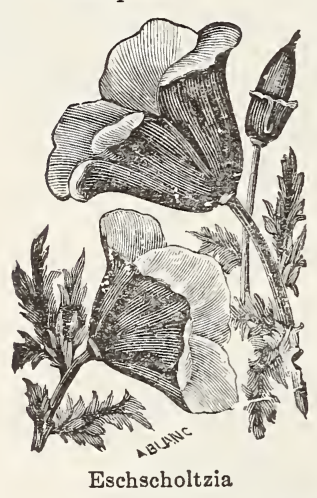

HOLLYHOCK,-Double mixed,-choice, 10c pkt. HYACINTH BEAN, - See Dolichos.

LARKSPUR,-Double dwarf rocket, mixed,-Free flowering hardy annuals, flowers borne in long spikes, 5c pkt.

LOBELIA, - Erinus, mixed, a trailing plant, producing bright. blue, white or rose flowers, $10 \mathrm{c}$ pkt.

LOVE-IN-A-MIST,-“Nigella,"-Dwarf, double, foliage feathery, with white or blue flowers, pretty annuals, 5c pkt.

MARIGOLD,-Double African Mixed,-Very effective for groups and masses; a favorite annual, $5 \mathrm{c}$ pkt.

MARIGOLD,-Double French Dwarf,-Mixed, 5c pkt.

MARVEL OF PERU, - "Four O'Clock,"-Mixed, beautiful summer blooming annual of bushy habit, large flowers of white, yellow, crimson and striped, 5c pkt.

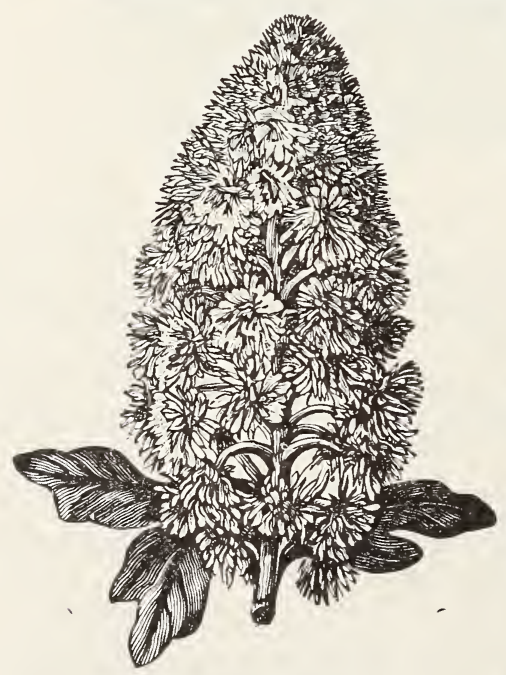

MIGNONETTE, - Large flowering, the common sweet mignonette, very fragrant, $5 \mathrm{c}$ pkt. $30 \mathrm{c}$ oz.

MIGNONETTE MACHET, The Dwarf French variety, with broad spikes of fragrant red flowers, one of the best varieties for outdoor culture, $10 \mathrm{c}$ pkt.

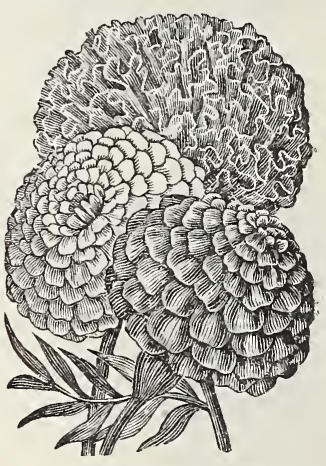

Double African Marigold

MIGNONETTE,-Defiance,-Produces mammoth spikes deliciously fragrant, one of the best for indoor culture, $10 \mathrm{c}$ pkt., $\$ 1.00 \mathrm{oz}$.

\section{MYOSOTIS,-See Forget-me-not.}

\#JAPANESE IMPERIAL MORNING GLORY,Mixed, rapid climber, producing mammoth flowers; great variety of coloring, 5c pkt.

Mignonette Machet MORNING GLORY,-See Convolvulus. 
"Our Seeds are Northern Grown, None Better at Any Price."

\section{FLOWER SEEDS-(Continued)}

\#NASTURTIUM, - Tall, finest mixed, beautiful and luxuriant climber, of easiest culture, flowering until frost comes, $5 \mathrm{c}$ pkt., $15 \mathrm{c}$ oz., $50 \mathrm{c} 1 / 4 \mathrm{lb}$., $\$ 1.50 \mathrm{lb}$.

NASTURTIUM,-Dwarf, finest mixed, very popular and showy for masses and border, $5 \mathrm{c}$ pkt., $15 \mathrm{c}$ oz., $60 \mathrm{c} 1 / 4 \mathrm{lb} ., \$ 1.75 \mathrm{lb}$.

NICOTIANA,-Affinis,-Very fragrant, $5 \mathrm{c}$ pkt.

PETUNIA,-Single large flowering, mixed, many beautiful colors and combinations, $5 \mathrm{c}$ pkt. PETUNIA,-Double large flowering, mixed, a magnificent strain, very beautiful shades, $50 \mathrm{c}$ pkt.

\section{PANSIES}

HOWARD'S EXTRA LARGE-FLOWERED CHOICE MIXED PANSIES,-This is a very choice strain of Pansy seed, and under proper cultivation produces mammoth flowers of the most beautiful colors, 25c pkt.

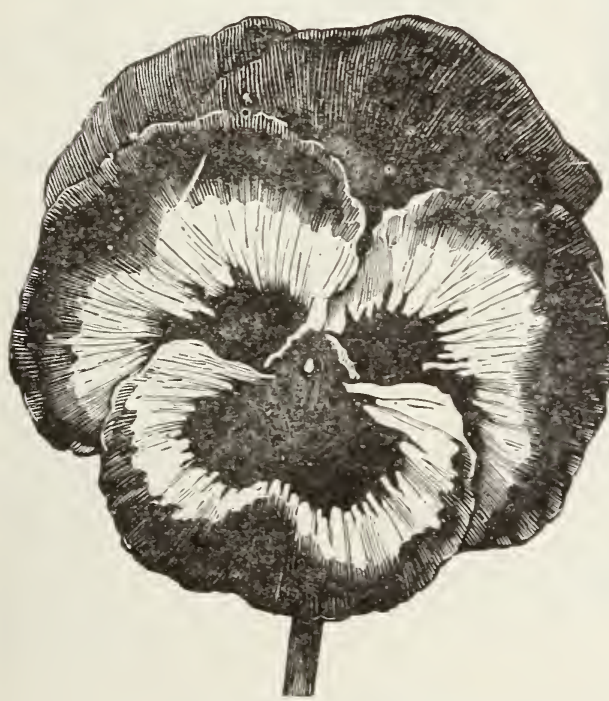

Howard's Extra Large Flowered Choice Mixed Pansies. Pkt. 25c.

ENGLISH FINEST MIXED,-10c pkt. GOOD MIXED, - 5 c pkt.

PHLOX-Drummondii-grandiflora mixed, for beds and massing nothing can surpass these beautiful annuals, 10c pkt.

PHLOX, - Dwarf or nana compacta, mixed, these form little round compact bushes about six inches high, thickly studded with flowers, 10c pkt.

PINKS, - See Dianthus and Carnation.

POPPIES, - Single Mixed, great variety of colors, very showy, $5 \mathrm{c}$ pkt.

POPPIES,-California-See Eschscholtzia.

POPPIES, - IVIixed carnation flowered, 5c pkt.

POPPIES,-Iceland Mixed,-10c pkt.

POPPIES,-Shirley Finest Mixed,-Extra Fine strain, $\check{x} \mathrm{c}$ pkt.

PORTULACA, - Single mixed, brilliant dwarf annuals, 6 in. high, for low beds and masses of color they are indispensable, $5 \mathrm{c}$ pkt.

PORTULACA,-Double, these make perfectly gorgeous masses of color, $15 \mathrm{c}$ pkt.

RICINUS,-Castor Oil Plant, mixed, rapid growing foliage, annual, palm leaves, $5 \mathrm{c}$ pkt., $30 \mathrm{c} \mathrm{oz}$.

SALPIGLOSSIS,--Large flowering mixed, a beautiful flowering annual, bearing large flowers of many pretty colors, $10 \mathrm{c}$ pkt.

SALVIA SPLENDENS, Bonfire,-Perennial but blooms the first season, bright scarlet, fine for bedding, 10c pkt.

SCABIOSA,-Mourning Bride, Showy border plant. Dwarf, double mixed, $5 \mathrm{c}$ pkt.

STOCKS,--Large Flowering Ten Weeks, mixed, highly fragrant, very pretty and a deservedly popular annual, $10 \mathrm{c} \mathrm{pkt.}$

SUNFLOWER,-Double Dwarf, $5 \mathrm{c}$ pkt.

SUNFLOWER,-Mammoth Russian, 5c pkt.,

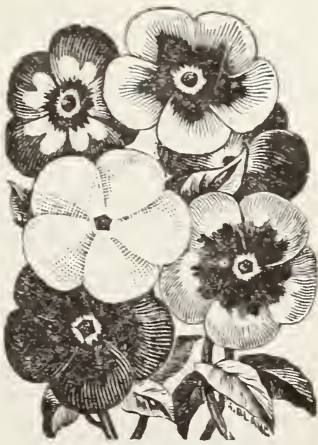

Phlox-Drummondii 


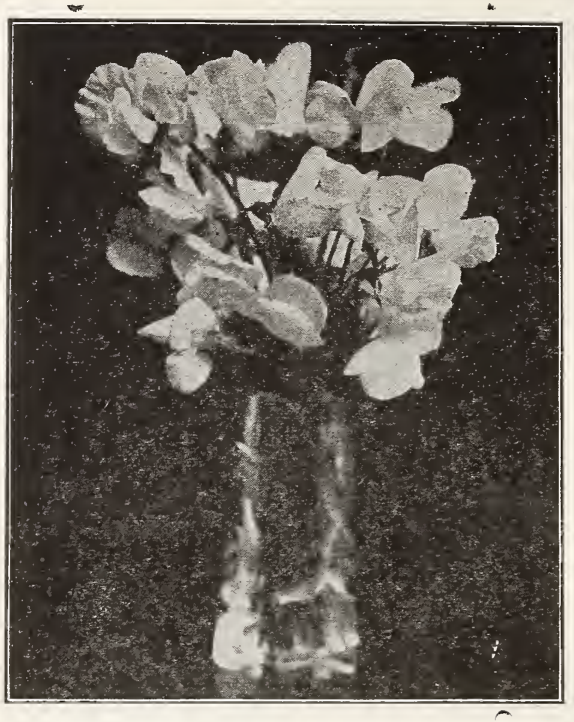

\section{FLOWER SEEDS-(Con.) SWEET PEAS}

Our list of Sweet Peas has been carefully revised with a view of keeping it strictly up to date. Should you miss some old favorite in the list, it has been discarded in favor of an improved sort. White seeded varieties should not be sown until the ground is comparatively dry and warm. If sown under wet and cold conditions the seed may rot in the ground. With few exceptions Sweet Peas are black seeded and do not appear to be affected like the white seeded sorts.

\section{APPLE BLOS-}

Pkt. Oz. 1/4Lb. $1 / 2$ Lb. Lb.

SOM, - Rose and

BlushWhite, $.05 \quad .10 \quad .35 \quad .60 \$ 1.00$

BLACK KNIGHT,

- Very deep

maroon shaded

black

$\begin{array}{lllll}.05 & .10 & .35 & .60 & 1.00\end{array}$

BLANCHE

BURPEE,-

Superb, is

pure white,

BLANCHE FER-

RY, 一 Pink

and white

$\begin{array}{llllll}\text { wings, } & .05 & .10 & .35 & .60 & 1.00\end{array}$

$\begin{array}{lllll}.05 & .10 & .35 & .60 & 1.00\end{array}$

COUNTESS OF RADNOR-Delicate lavender, $\begin{array}{llllll}\text { DOROTHY ECKFORD, - Pure, white, beautiful large flowers, } & .05 & .10 & .35 & .60 & 1.00\end{array}$ $\begin{array}{llllll}\text { HON. MRS. E. KENYON, -The finest primrose yellow, } & .05 & .10 & .35 & .60 & 1.00\end{array}$ JANET SCOTT, $\rightarrow$ A grand deep rich pink, KING EDWARD VII,-Bright crimson splendid,

LADY GRISEL HAMILTON,-A grand pale lavender,

LORD NELSON,-The richest deep navy blue,

MISS WILMOTT,-Brilliant orange pink, very large,

MRS. WALTER WRIGHT, -An exquisite shade of mauve,

PRINCE OF WALES, - The finest bright rose,

$.05 \quad .10$

$.05 \quad .10$

$.35 \quad .601 .00$

$\begin{array}{lllll}.05 & .10 & .35 & .60 & 1.00\end{array}$

$\begin{array}{lllll}05 & .10 & .35 & .60 & 1.00\end{array}$

$\begin{array}{llllll}.05 & .10 & .35 & .60 & 1.00\end{array}$

$\begin{array}{lllll}.05 & .10 & .35 & .60 & 1.00\end{array}$

$\begin{array}{lllll}.05 & .10 & .35 & .60 & 1.00\end{array}$

QUEEN ALEXANDRA, - Bright scarlet,red, almost true scarlet.05 $\quad \begin{array}{lllll}.10 & .35 & .60 & 1.00\end{array}$

HOWARD'S CHOICE SPECIAL MIXTURE, of selected, named

and Spencer varieties.

MIXED COLORS,-Fine Mixture,

$\begin{array}{lllll}.05 & .10 & .25 & .50 & 1.00\end{array}$

\section{SPENCER VARIETIES-Sweet Peas}

These are noted for their unusually large-sized flowers and for the waved or fluted appearance of the petals. They are frequently referred to as "Orchid-flowering" Sweet Peas.

COUNTESS SPENCER,-A lovely soft rose-pink, shading deeper at the edges,

FLORENCE MORSE SPENCER,-Delicate blush, with pink margin very large,

FLORENCE NIGHTINGALE,-Largest and finest pure lavender,

KING EDWARD SPENCER,-Bright Crimson Scarlet,

PRIMROSE SPENCER,-The finest primrose-yellow,

WHITE SPENCER, - A pure wavy white, very large,

Pkt. Oz. $\quad 1 / 4 \mathrm{Lb}$. $.10 \quad .25 \quad .75$

$.10 \quad .25 \quad .75$

$.10 \quad .25 \quad .75$

$.10 \quad .25 \quad .75$

$.10 \quad .25 \quad .75$

$.10 \quad .25 \quad .75$

SWEET WILLIAM,-Single mixed, an old favorite, rich variety of color, deliciously sweet scented, 5c pkt.

VERBENA,- - Finest mixed, for garden beds or massing, the verbena is unrivaled; flowers from spring until late in autumn, $10 \mathrm{c}$ pkt.

WALLFLOWER,-Double large flowering mixed, exquisitely fragrant, long spikes of double flower, hardy perennial, 10c pkt.

ZINNIA, - Double mixed, very showy, free flowering, hardy annual, 5c pkt. 
BIRD SEEDS

CHOICE MIXED, per lb., $35 \mathrm{c}$ CANARY,-Choice Sicily, " $35 \mathrm{c}$ HEMP, MILLETT,-per lb. $10 \mathrm{c}, 3 \mathrm{lbs} 25 \mathrm{c}$
RAPE,-per lb. , Mammoth Russian, $15 \mathrm{c}$ per quart, 2 qts. $25 \mathrm{c}$.

ARTICHOKE JERUSALEM,

\section{VEGETABLE ROOTS}

ASPARAGUS ROOTS,-See page 2.

CHIVES,

.20c per doz., $\$ 1.00$ per 100

\section{List of GRASSES and CLOVER Adapted to this Climate} PRICES SUBJECT TO MARKET CHANGES

CANADA BLUE GRASS,-ValWeight

uable for dairy pastures, 30 lbs. to acre, 14 lbs.

CREEPING BENT GRASS,-Excellent for lawns, succeeds well in most situations, $60 \mathrm{lbs}$. to acre, $20 \mathrm{lbs}$.

ENGLISH RYE GRASS, - A valuable grass, $60 \mathrm{lbs}$ to acre, 24 lbs.

HARD FESCUE, - A dwarf growing grass, succeeding well in dry situations, $30 \mathrm{lbs}$. to acre,

$12 \mathrm{lbs}$

HUNGARIAN GRASS,-Is a valuable annual forage plant, 1 bushel to the acre,

ITALIAN RYE GRASS,-Thrives in almost any soil and yields early and abundant crops, $50 \mathrm{lbs}$. to acre

KENTUCKY BLUE GRASS, Fancy, valuable for lawns and pastures, 50 lbs. to acre,

MEADOW FESCUE,-Of great value in mixtures for permanent pastures, 50 lbs. to acre,

MEADOW FOXTAII, - Is the principal grass in all rich, natural pastures, $30 \mathrm{lbs}$. to acre,

ORCHARD GRASS, - One of the most valuable grasses either for pasture or hay, 4 bushels to acre, 14 lbs.

RED TOP GRASS, - In chaff, 4 bushels to acre,

RED TOP GRASS, FANCY,-Or extra re-cleaned seed, $32 \mathrm{lbs}$. to acre, $32 \mathrm{lbs}$.

RHODE ISLAND BENT GRASS, -A very fine variety for lawns, 60 lbs. to acre

ROUGH STALKED MEADOW GRASS,--Valuable for pastures and meadows, particularly on damp soil, 30 lbs. to acre,

$48 \mathrm{lbs}$.

$18 \mathrm{lbs}$

14 lbs.

HEEP'S FESCUE, - Short and dense in growth, excellent for sheep pastures, $40 \mathrm{lbs}$. to acre, $12 \mathrm{lbs}$. $14 \mathrm{lbs}$.
Weight

Per Bushel.

SWEET VERNAL TRUE PEREN-

NIAL, - Emits an agreeable odor, which it imparts to the hay, $3 \mathrm{lbs}$. to acre with other grasses,

$10 \mathrm{lbs}$.

TALL MEADOW FESCUE,-Very early, nutritive and productive. Good for pastures on wet or clay soils, $40 \mathrm{lbs}$. to acre,

$14 \mathrm{lbs}$.

TALL MEADOW OAT GRASS,Recommended for soiling, being rapid and luxuriant in its growth 50 lbs. to acre,

$10 \mathrm{lbs}$

TIMOTHY OR HERD GRASS,-

The most important of hay grasses. The seed we offer is of the very highest quality, $25 \mathrm{lbs}$. to acre,

VARIOUS LEAVED FESCUE,Valuable for permanent pasture, especially on high altitudes, 40 lbs. to acre,

14 lbs.

WOOD MEADOW GRASS,-Of early growth, thriving well under trees,

14 lbs.

ALFALFA OR LUCERNE, - In

light soils, particularly in southern altitudes, it is invaluable,

ALSIKE OR HYBRID CLOVER,Equal in nutritive value to the Red or Pea Vine Clover, and excellent for land that is cloversick,

MAMMOTH RED OR PEA VINE CLOVER, -

$60 \mathrm{lbs}$

$60 \mathrm{lbs}$.

RED CLOVER MEDIUM,- 60 lbs.

SCARLET OR CRIMSON CLOVER,- - Sow in July or August for mowing the ensuing Spring,

SWEET CLOVER,-Grown for Bee food and as a Fertilizer,

$60 \mathrm{lbs}$.

WHITE CLOVER, - Should be used in all mixtures for permanent pasture and for lawns,

OUR SPECIAL GRASS MIXTURE FOR PASTURES,-Usual quantity sown to the acre, 3 bushels. Per bushel of 14 lbs., $\$ 3.75$.

We recommend sowing separately from this, $10 \mathrm{lbs}$. mixed clover per acre.

OUR SPECIAL GRASS MIXTURE FOR HAY-On ordinary soils use 3 bushels per acre. In ordering state whether soil is dry, medium or wet. Per bushel of 14 lbs., $\$ 3.75$. 
"Our Seeds are Northern Grown, None Better at Any Price."

\section{GRAINS-Price According to Market and Subject to Change}

BARLEY,-2 or 4 rowed, Choice Montana, price variable, per bushel 48 lbs.

BARLEY,-York State,-Fanicy, Market price.

BUCKWHEAT,-Silver Hull-48 lbs. per bushel. Japanese, 48 lbs. per bushel.

OATS,-Choice White-32 lbs. per bushel.

OATS,-White Swedish,-Selected,-Regenerated,-Wisconsin Grown,-These oats give excellent satisfaction, straw is strong, not apt to lodge, yield very heavy, per bushel 32 lbs. Price per bushel $\$ 2.25$, subject to change.

RAPE, -Dwarf Essex,-In drills 5 lbs. to acre, broadcast 10 lbs. to acre, per lb. 20c., per 100 lbs., $\$ 18.00$. Subject to market changes.

RYE,-Spring.-For sowing in the spring, 56 lbs. per bushel.

RYE,-Winter,-For fall sowing, 56 lbs. per bushel.

VETCHES,-Spring Tares, -60 to $100 \mathrm{lbs}$. to acre, prices variable.

VETCHES, - Sand Winter, a Hairy Vetch, -30 to $50 \mathrm{lbs}$. to acre, prices variable.

WHEAT,-Spring, -60 lbs. per bushel. Winter, -60 lbs. to bushel.

HUNGARIAN GRASS,-One of the most valuable soiling plants, excellent for green fodder or hay, yields enormously; sow from June to August, 48 lbs. per bushel. 1 to $11 / 2$ bushels per acre. Market price.

MILLET,-German or Golden,-Similar to above, flower stem more branching, $50 \mathrm{lbs}$. per bushel. Market price.

MILLET,-Japan,-Barnyard (Crus-galli). Exceedingly heavy yielder, requires very rich soil. $20 \mathrm{lbs}$. to $30 \mathrm{lbs}$. to the acre. Per $1 \mathrm{~b} .15 \mathrm{c}$, per $100 \mathrm{lbs} . \$ 10.00$, subject to change.

FLAX,-Extra re-cleaned, per 1b. 20c,

Special prices on larger quantities.

\section{IAWN GRASS SEED}

OUR LAWN GRASS SEED is a specially reliable mixture of fine growing grasses, entirely free from weed seeds and can be depended on to produce a perfect, velvety green turf if properly sown and cared for. Quantity required per acre, 4 bushels. Price per quart, 25c., 1-2 peck, 90c., peck, $\$ 1.75$, bushel, $\$ 7.00$.

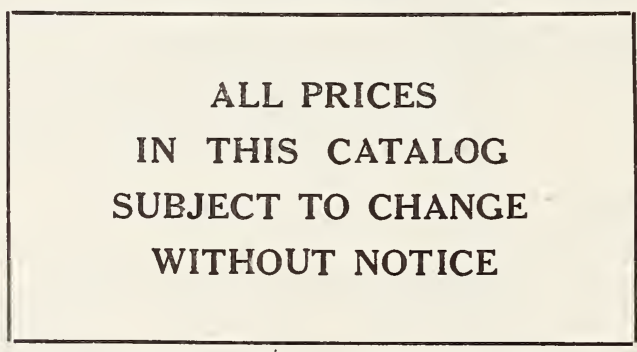

\section{REPAIRING LAWN MOWERS}

We repair and sharpen Lawn Mowers of all kinds, putting them in first-class working order. Should any be sent to us that are too nearly worn out to repair, we will so advise.

\section{LAWN AND GARDEN ROLLER}

Two Sections, each $12 \times 24$ inches, weight about 450 lbs. Price $\$ 27.50$.

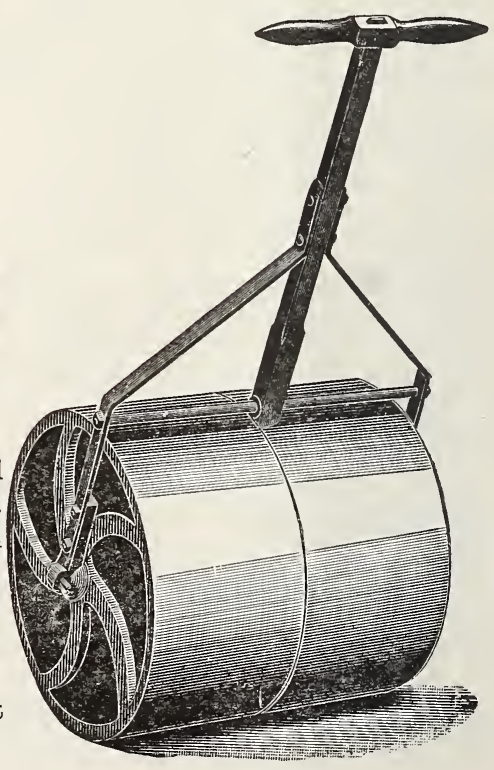




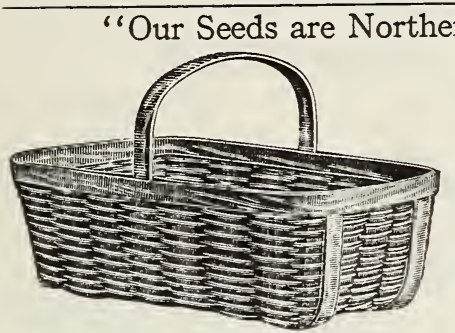

Vegetable handles over, No. $1,18 \times 11 \times 6$

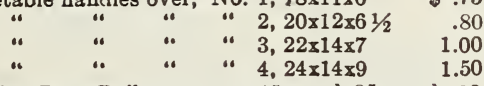

BASKETS

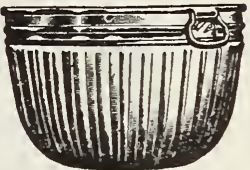

(1......45c and $85 \mathrm{c}$ and .90 Berry-One quart standard-market price. Oblong or Stable (cut under handles)

$11 / 2$ " "

Two “" “ " 4.00

Cheap Diamond Market............12c to .20 Covered Cheap Diamond Market.......15c to .50 One bushel, Common Stave......... $11 / 2$ bushel Ash, $\quad 1.25$ and 1.85 $11 / 2$ bushel Ash,

2.25
2.50

\section{FEDERAL GARDEN BARROW}

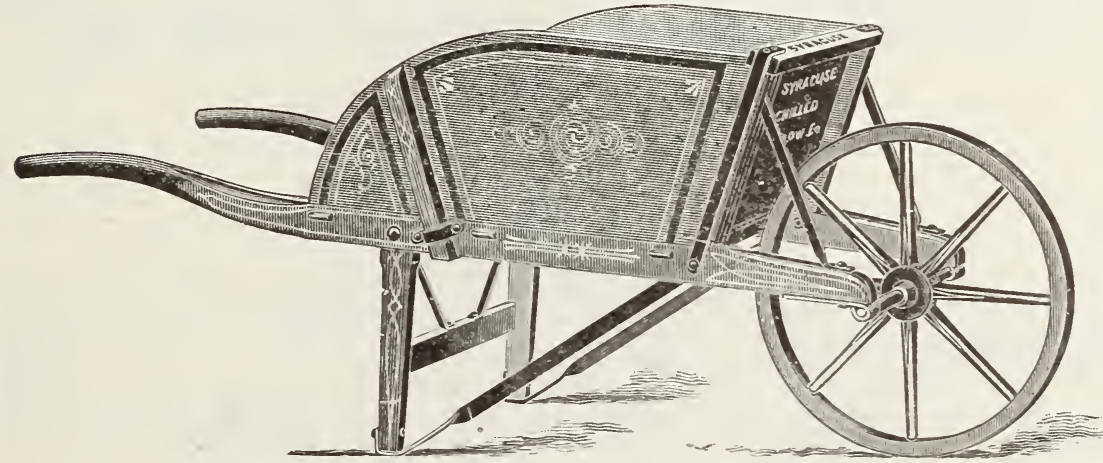

Boys'

A strong, well-made Garden Barrow, nicely painted.

Common Size,

Large Size,

\section{OUR CUSTOM GARDEN BARROW}

Very strong, heavily ironed-and the best barrow we know of.

No 4, Medium,

No 5, Large,

No. 6, Extra Large

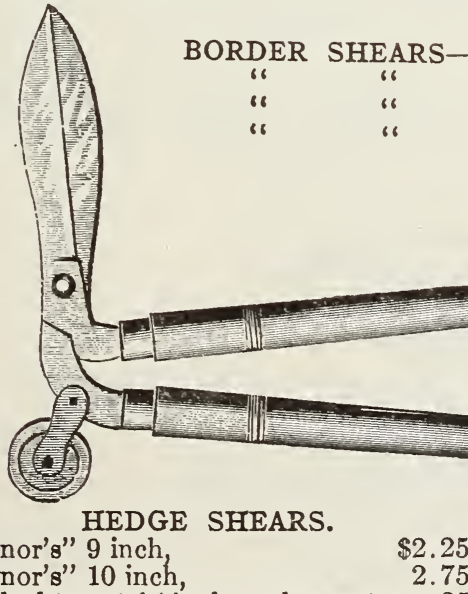

"Saynor's" 9 inch 


\section{SYRACUSE REVERSIBLE SULKY PLOW}

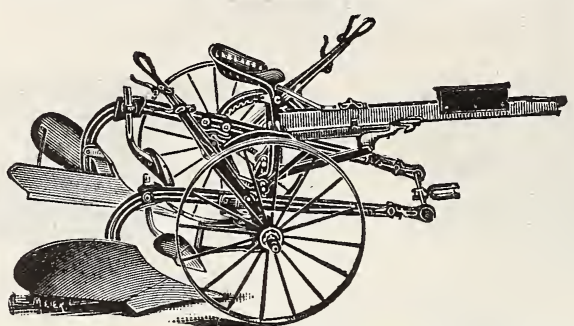

One of the best reversible Sulky Plows made, either for Hillside or Level land. Equipped with Foot Trip which operates power lift, also Foot Regulated Pole Shift, can be used with either two or three horses.

No. 31-39 is the popular size.

Price 2-Horse equipment,

$\$ 100.00$

Price 3-Horse equipment,

102.50

\section{SYRACUSE STEEL BEAM SWIVEL PLOW "822"}

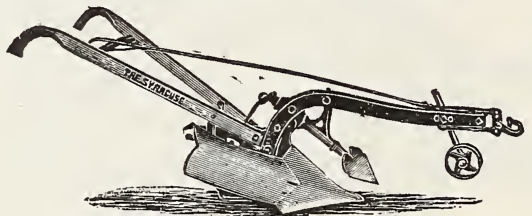

This Plow will certainly please you, it is light yet very strong, has ample throat capacity and close-fitting joints to prevent clogging.

Price complete with Wheel and Jointer, and chilled mouldboard " "

$\$ 29.75$

\section{SYRACUSE NO. 60 SWIVEL PLOW}

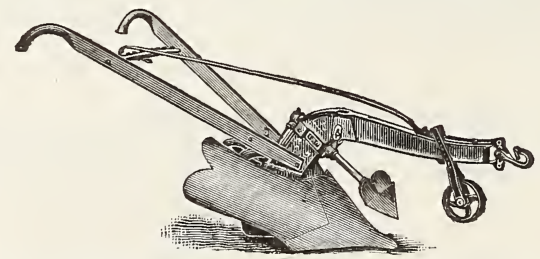

An excellent working Plow, well-made, strong and reliable.

Price complete, with cast mouldboard, ".

\section{SYRACUSE STEEL BEAM LANDSIDE PLOW "NO. 3I"}

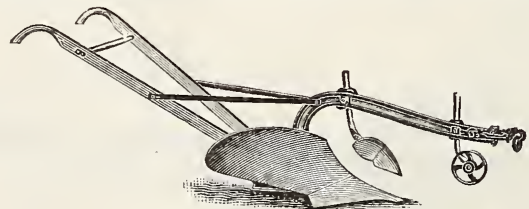

A splendid Plow. If you have difficult land to turn, this will do it when other Plows fail.

Price complete with Steel mouldboard,

\section{HILISDALE LANDSIDE PLOW}

A very good Low-Priced, Two-horse Plow, Cast Beam.

Price Plain,

Price with Wheel, 
"Our Seeds are Northern Grown, None Better at Any Price."

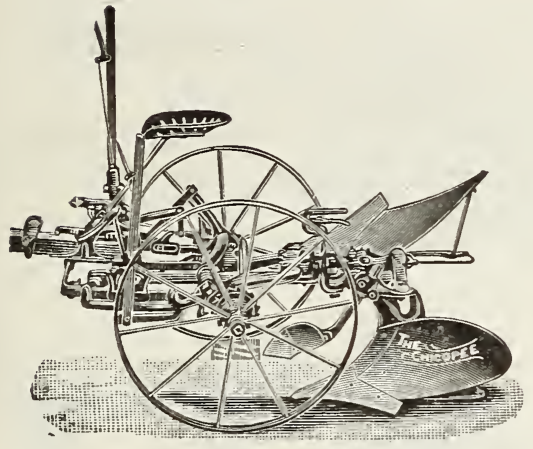

\section{The CHICOPEE REVERSIBLE SULKY PLOW}

An excellent reversible Sulky Plow, easily handled, strong and does splendid work on either hillside or level land.

Price complete. with Jointers,

$\$ 100.00$

\section{The John Deere Two-Way Sulky Plow}

One of the standard reliable sulky plows,
No. 1441C No. $1341 \mathrm{C}$ Weight 652 . Price $\$ 100.00$ and $\$ 102.50$

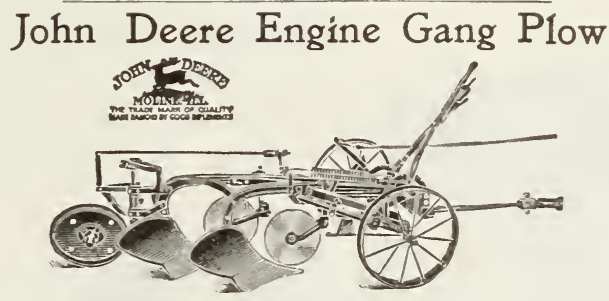

With High and Level Power Lift and quick detachable shares.

No. M. P. $214 \mathrm{C}-2$ Bottom 28 in. cut, weight 790 lbs.,

Price $\$ 185.00$

Third Bottom and Beam Attachment,

55.00

\section{The Arlington Swivel Plow with Jointer}

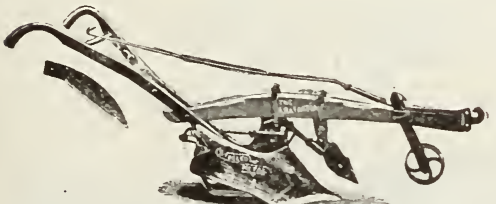

This is one of the best Swivel Plows ever offered to the farmers of Berkshire County. They are very easy for the team and for the man,-are a strong plow, and do nice work. Made either with wood or steel beam. The No. 29 with Wood Beam is the Favorite.

No. 30, Large Two-Horse, complete with Wheel and Joiner, 135 lbs.,

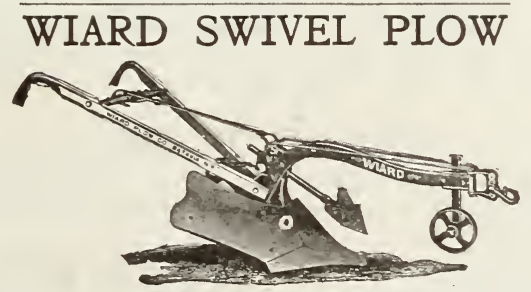

A good Plow, with an excellent reputation and capable of doing first-class work. No. 120, with Steel Beam and Steel Mouldboard, with Wheel and Jointer, . $\$ 31.50$ No. 120, with Steel Beam and Cast Mouldboard, No. 126, with Steel Beam and Steel Mouldboard, " No. 126, with Steel Beam and Cast Mouldboard,

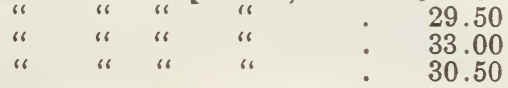




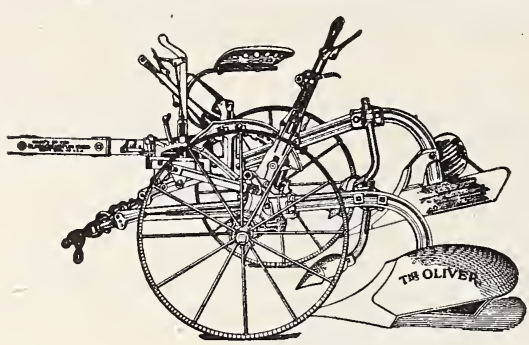

\section{THE OLIVER REVERSIBLE SULKY PLOW}

A very reliable "two-way" sulky plow, strong, easily operated, does excellent work.

No. $23 \mathrm{~A}-83 \mathrm{D}$ is the popular size.

Price $\$ 100.00$ and $\$ 102.50$

\section{OLIVER SWIVEL PLOW}

A Practical Plow

No. 508, complete, . . . . $\$ 27.00$

No. 509 , “ $\quad$. $\quad . \quad$. 28.50
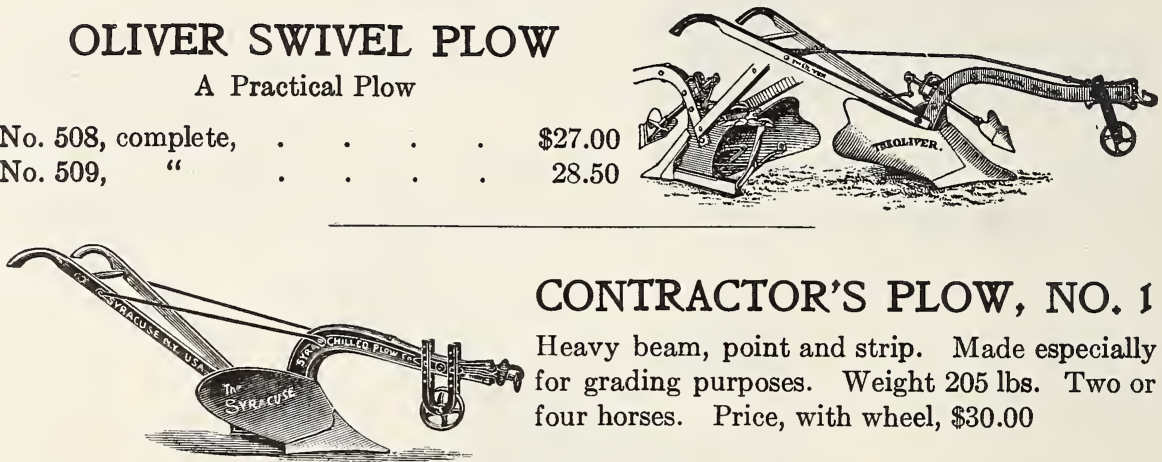

CONTRACTOR'S PLOW, NO. I

Heavy beam, point and strip. Made especially for grading purposes. Weight 205 lbs. Two or

four horses. Price, with wheel, $\$ 30.00$

\section{PAVEMENT PLOW, NO. 98}

A favorite with contractors. Has reversible crucible steel point. loop handle wear irons built for hard work, such as tearing up cobblestones and macadam. Four or six horses. Weight 280 lbs., $\$ 45.00$

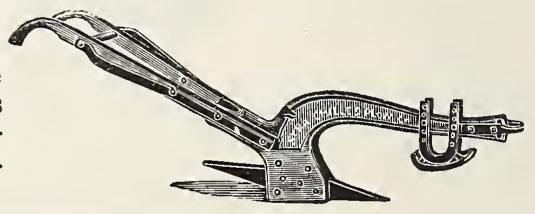

TRUSS BEAM GRADING PLOW, No. 99

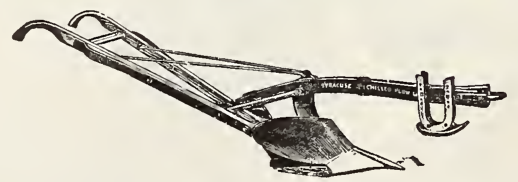

For severe grading purposes in shale or hard pan. Four or eight horses. Weight $310 \mathrm{lbs}$. $\$ 60.00$.

\section{THE ARIMSBY LANDSIDE PLOW}

Wood Beam and Cast Mouldboards. For light work we recommend this plow.

No. 1, Small One-Horse, \$7.50. No. 2, Medium One-Horse, $\$ 9.00$. No. 3, Large $\$ 10.75$.

\section{SUBSOIL PLOW}

The Subsoil Plow follows in the furrow of the plow, turning the surface soil.

No. 1 , Two-Horse, with draft rod, $\$ 16.50$; with draft rod and wheel, $\$ 18.00$.

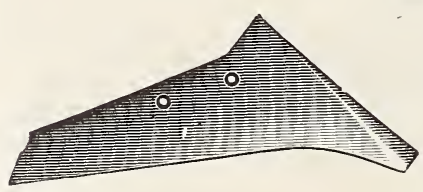

\section{PLOW REPAIRS}




\section{THE JOHN DEERE LOW DOWN MANURE SPREADER}

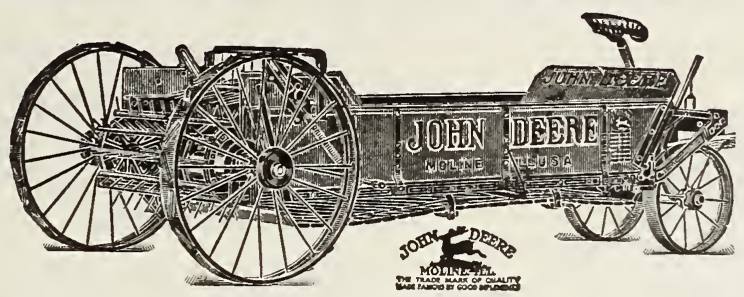

The value of having a spreader Low Down for loading is readily understood. The John Deere is not complicated, is giving splendid satisfaction. Weight of size B-2 Horse, 1813 lbs. Price $\$ 200.00$.

\section{THE CUTAWAY LIGHT TRACTOR HARROW}

The Cutaway Light Tractor Harrow has 2918 inch dises, cuts $71 / 2 \mathrm{ft}$. wide, has center disc, weight $965 \mathrm{lbs}$.

Has very rigid main frame of heavy angle iron stoutly braced. This harrow thoroughly pulverizes the soil leaving it in good level condition. Price $\$ 165.00$.
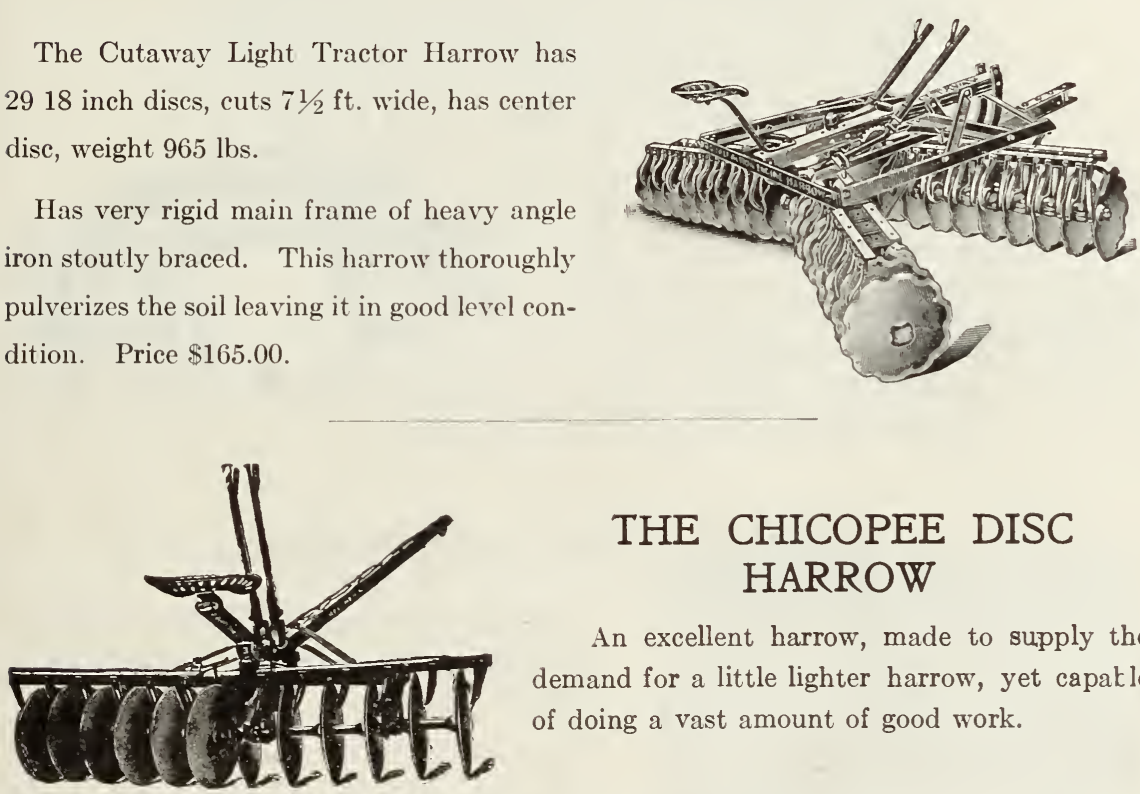

\section{THE CHICOPEE DISC HARROW}

An excellent harrow, made to supply the demand for a little lighter harrow, yet capakle of doing a vast amount of good work.

Price complete with Scraper Attachment, Whiffletrees and Evener with 12-16 in.Discs, $\$ 54.50$ Price Cut-Out Discs extra, $\$ 3.00$.

\section{ACIME PULVERIZING HARROW}

The "Acme" cuts, crushes, levels, turns and smoothes at one operation, making a perfect seed bed. The No. 23 is the standard two-horse size, cuts 6 feet, 6 inches wide, weighs $130 \mathrm{lbs}$. Price $\$ 30.00$

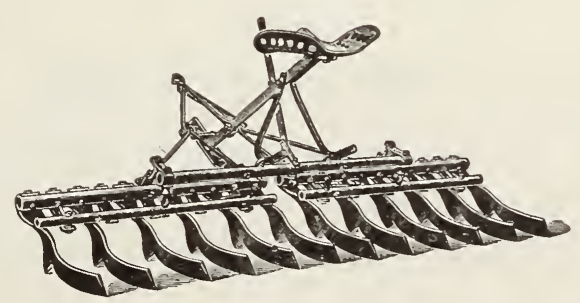




\section{STEEL FRAME SMOOTHING HARROW}

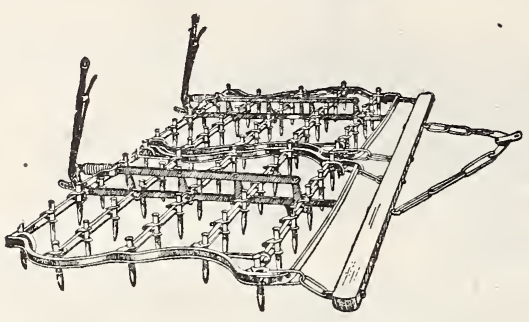

CAN BE INSTANTLY CHANGED

FROM A SMOOTHING TO A

REGULAR SPIKE TOOTH

HARROW. TEETH ARE ADJUST-

ABLE TO ANY ANGLE BY THE

LEVERS

These are the VERY BEST STEEL SMOOTHING HARROWS manufactured, strong and well made.

Price--1 Sections, 25 teeth, $\$ 16.00$

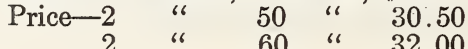

Price-3 Sections, 75 teeth, $\$ 44.00$

\section{CLARK'S CUTAWAY HARROW}

Clark's Cutaway Harrows are well known and hardly need description here, they are made in Double Action, that is double sets of gangs, (see cut). Regular Double Lever Cutaway, and Double Lever Solid Disc, and in many sizes, the sizes most suitable for this section are:-

Double Action, 20-16 in. Discs, . . $\$ 83.00$ With extension head, $\$ 89.50$.

Double Lever Cutaway, 10-16 in. Discs, 47.00

\section{SPRING TOOTH HARROWS}

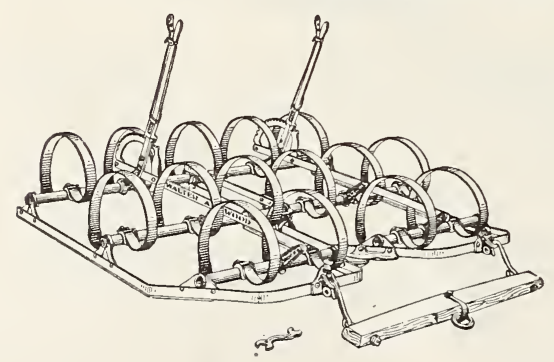

Either McCormick, Wood, or Syracuse, very strong, well made, serviceable harrows and very satisfactory, do excellent work.

Price, 9 Tooth, One Horse,

$\$ 18.50$

" 10 " " 19.00

" 15 " Two “ 35.00

" 17 " " $\quad 36.00$

\section{THE CULTIPACKER}

Acts as a roller and pulverizer, Double Gang, front gang 15 in. diameter, rear gang 12 in., is $8 \mathrm{ft}$. wide, Roller Bearings, and has 43 Sections. Price $\$ 90.00$.

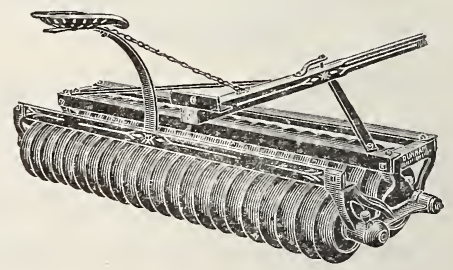




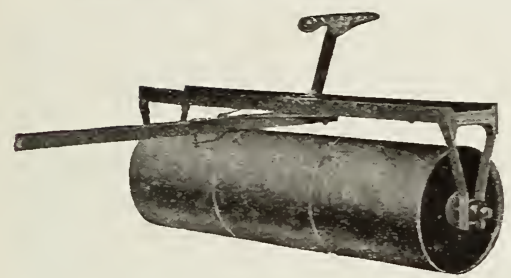

\section{STEEL FIELD ROLLER}

The drum of this roller is steel; it is 24 inches in diameter, has removable dust-proof boxes, closed ends and is an excellent one.

PRICE-3 SECTION-8 FT. 24 IN. DIAM.$\$ 55.00$

\section{VAN BRUNT GRAIN AND FERTILIZER DRILL}

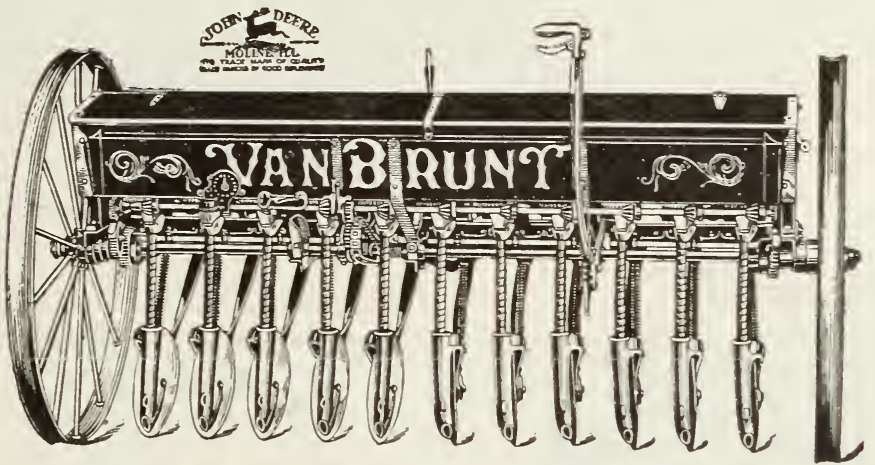

This Drill sows Grain, Grass Seed and Fertilizer perfectly. It has a positive force foed, will not break the grain, is light draft, is not complicated, evenly balanced, rests lightly on the horses' necks and is fully warranted. The Disc model is now the favorite, having almost entirely displaced the hoe type. Price 10 tube Disc Drill, Complete $\$ 175.00$.

\section{THE SUPERIOR DRILL}

A most excellent Drill, sows Grain, Grass Seed and Fertilizer perfectly. Positive accurate feed. Price with steel tube $10 \times 7$ size, $\$ 175.00$
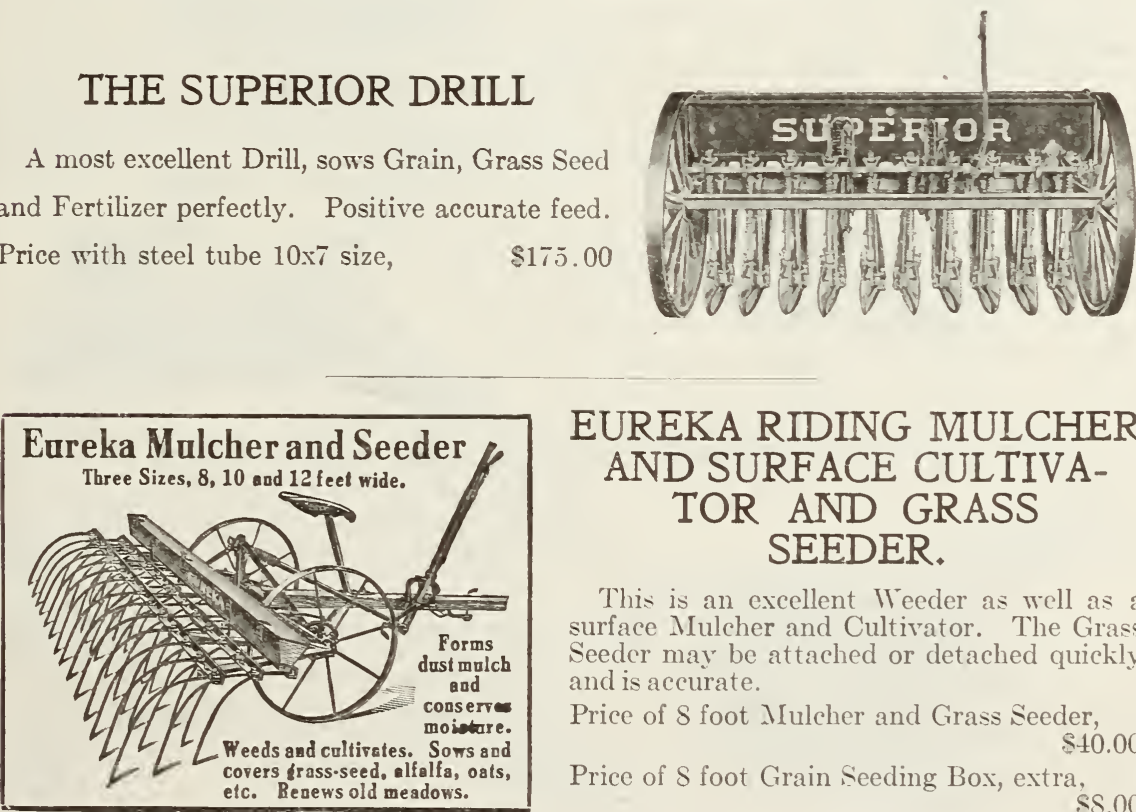

\section{EUREKA RIDING MULCHER AND SURFACE CULTIVA- TOR AND GRASS SEEDER.}

This is an excellent Weeder as well as a surface Mulcher and Cultivator. The Grass Seeder may be attached or detached quickly and is accurate.

Price of $S$ foot Mulcher and Grass Seeder,

Price of $S$ foot Grain Seeding Box, extra, 


\section{THOMPSON'S WHEELBARROW GRASS SEEDER}

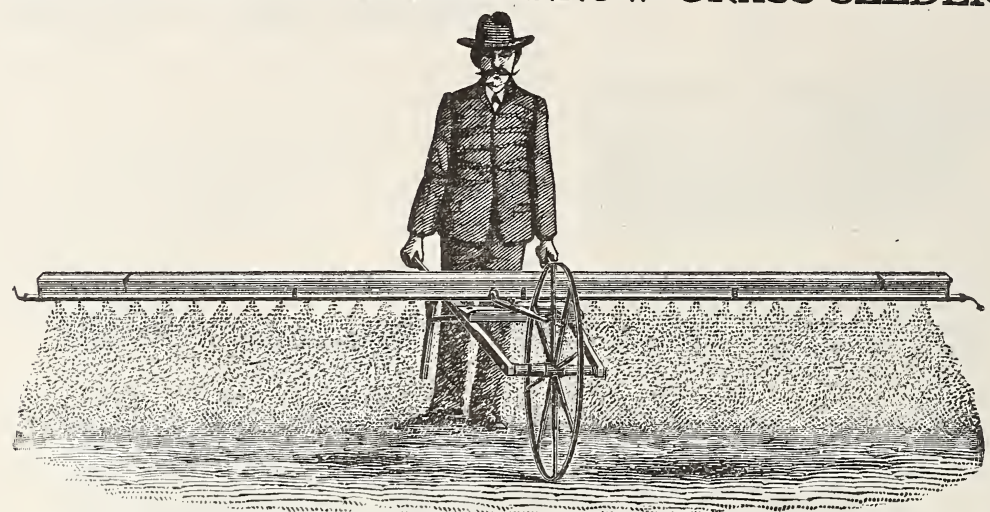

Sows any kind of Grass Seed perfectly and rapidly; width of Seeder Box $14 \mathrm{ft}$. Price $\$ 13.00$.

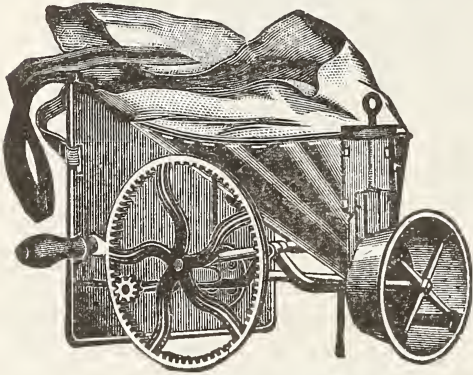

Cahoon Seeder

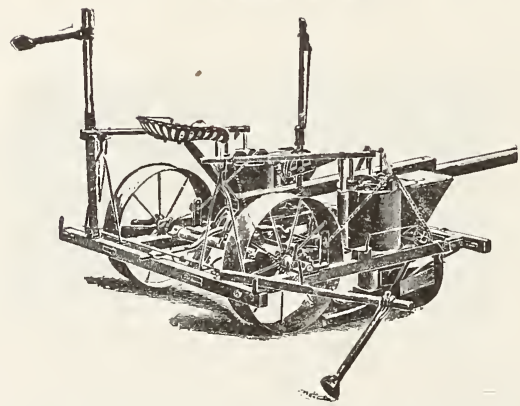

Eclipse Double Row Planter

Cahoon Broadcast Seed Sower

Sows both Grass Seed and Grain. Price $\$ 5.00$

Cyclone Broadcast Seeder

A very rapid and easily operated seed sower. Price $\$ 2.00$

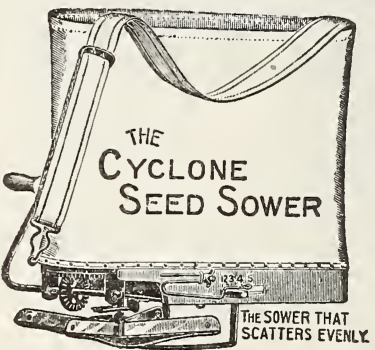

Eclipse Corn Planter and Fertilizer Distributer

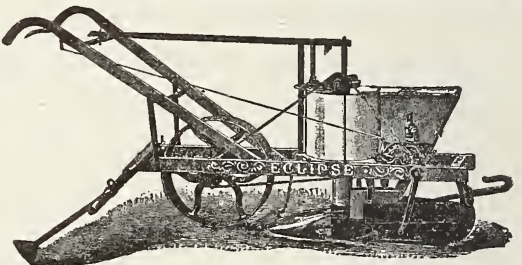

Plants Corn, Beans, Peas, etc., perfectly, and at the same time distributes evenly the fertilizer in such a manner that it does not come in direct contact with the seed.

Price, Single Row Planter,

"Double Row Planter,

$\$ 33.00$ 70.00

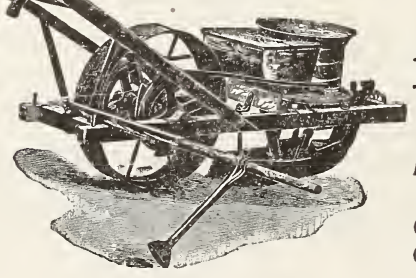

King of Cornfield Corn Planter and Fertílizer Sower, $\$ 33.00$

AN EXCELLENT PLANTER-VERY SIMPLE IN CONSTRUCTION 


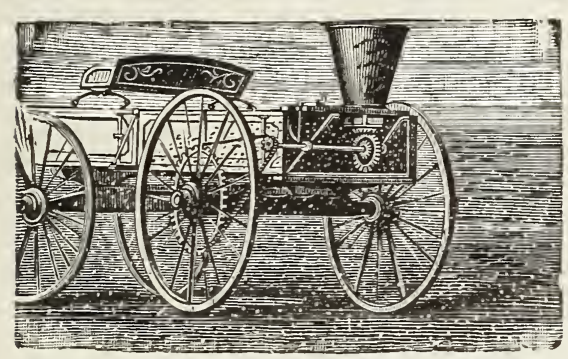

STROWBRIDGE IIMPROVED Broadcast Seed and Plaster Sower

From 50 to 75 acres can be sown with one team in a day.

Oats, Rye, Barley, Buckwheat, Hungarian, Grass, Clover, Timothy, and every variety of Seed and Grain requiring broadcasting can be sown with this machine; also with care, Plaster, Lime, Salt and Fertilizers. It can be attached to any farm wagon.

Price $\$ 14.50$

\section{STEEL BEAM SHOVEL PLOW}

Steel Point and Adjustable Steel Wings, and the price is only,

$\$ 7.25$

With Wood Beam,

$\$ 6.50$

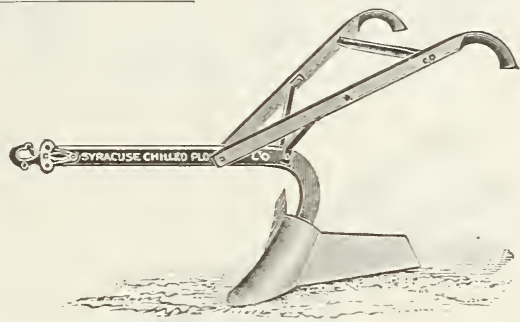

IMPROVED FURROWER AND MARKER

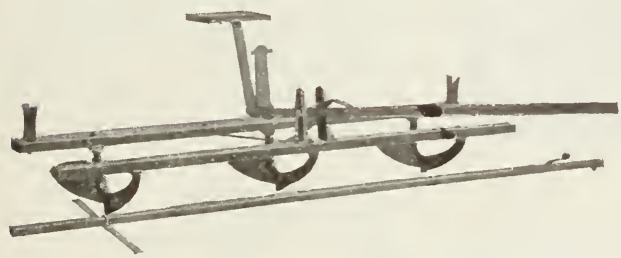

Marks and Furrows at the same time, adjustable to mark any width or depth. The wearing part of the runners is chilled iron, the wings are steel and the frame is oak, it is a labor-saver.

Price No. 1 makes 3 furrows at once, $\$ 20.25$. Price No. 2, makes 2 furrows at once, $\$ 15.50$.

\section{HAND CORN PLANTER}

Rapid and reliable. Price $\$ 2.75$

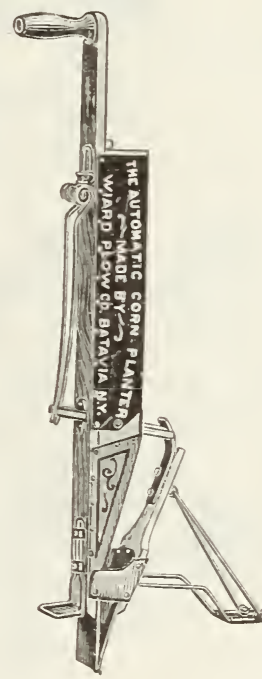

\section{Our New Potato Ridger, Coverer and Hoe}

Next to the complete potato planter this is the best tool for ridging and covering potatoes. It is adjustable in many ways, stands high and is especially valuable for hoeing potatoes.

PRICE WITH POLE and wings as shown,

PRICE WITH POLE and 20 inch discs

in place of wings,

17.50

-USE THE QUINNIPIAC AND MAPES FERTILIZERS TO RAISE NICE POTA-

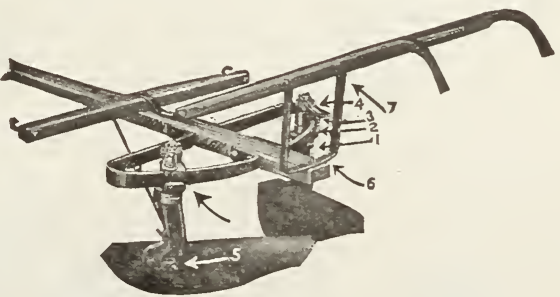
TOES. 

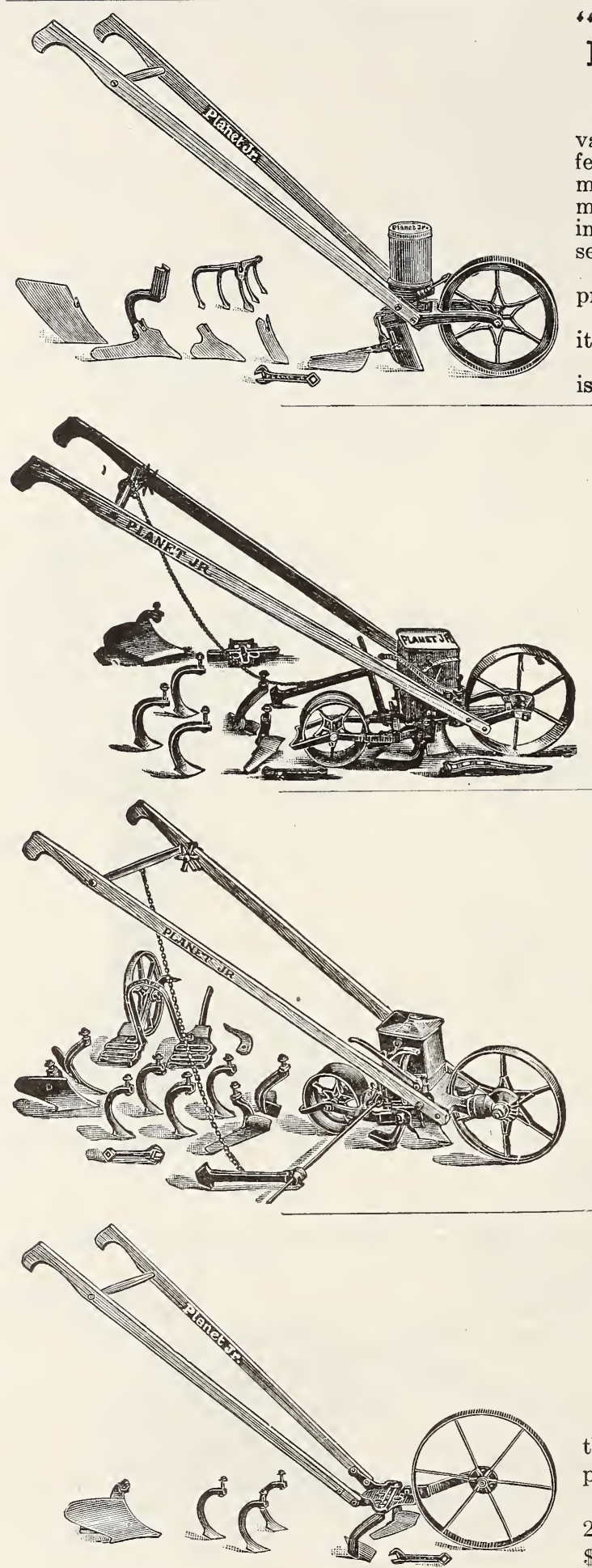

"Planet Jr." Combined Drill Seeder and Wheel

Hoe, No. 31

This is a combined tool of great value to the gardener who does not feel warranted in purchasing the more expensive market garden machine It sows from 1-4 in. to 2 inches deep, all kinds of garden seeds, very accurately.

Complete it is called No. 31 , price $\$ 13.00$.

As a DRILL SEEDER ONLY, it is known as No. $31 \mathrm{D}$, price $\$ 10.50$. As a WHEEL HOE ONLY, it is No. 33 , price $\$ 6.50$.

\section{"PLANET JR." NO. 4 Combined Hill and Drill Seeder, Single Wheel Hoe, Cultivator and Plow}

Hopper holds two and one-half quarts seed.

Price complete,- - - $\$ 19.50$

As a seeder only, - - $\$ 15.50$

\section{"PLANET JR." NO. 25}

Combined Hill and Drill Seeder, Double Wheel Hoe, Cultivator and Plow. Hopper holds two and one-half quarts. Substantial and accurate, two good machines in one. As a drill it is almost identical with the No. 4 Drill. As a wheel hoe it is identical with the No. 12 Double Wheel Hoe. Price $\$ 23.00$.

\section{"PLANET JR." NO. 17}

\section{Single Wheel Hoe}

Consists of one pair 6 in. hoes, three cultivator teeth, one garden plow. Price $\$ 8.75$.

No. 16 same as No. 17, but has 2 Rakes and Leaf Guard. Price $\$ 10.50$. 


\section{No. II "Planet Jr." Double and Single Wheel Hoe Combined} as shown. The best combined double and single wheel hoe made.

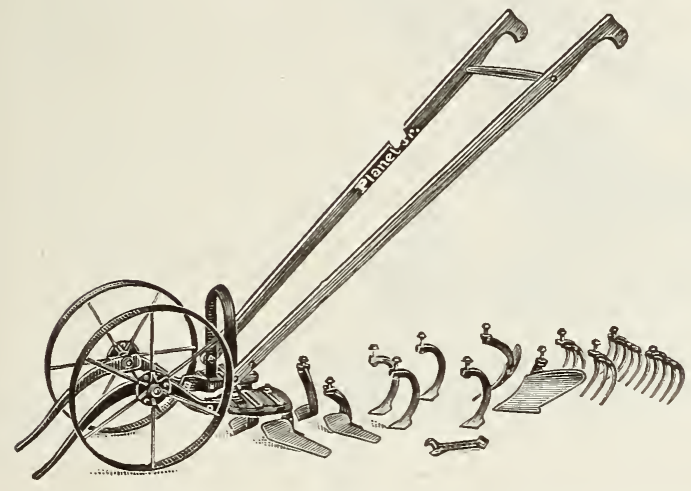

With this machine one man can do more and better work than six with ordinary hoes, Capable of almost an endless variety of changes.

Price complete, $\$ 16.00$ PLANET Jr. NO. 12, DOUBLE WHEEL HOE, CULTIVATOR AND PLOW, is identical with the No. 11 except the $4 \frac{1}{2}$ in Hoes and the rakes are omitted. PRICE $\$ 12.50$

We also sell this with only the long hoes (which are shown attached in cut) and without leaf guards; this we call the Plain Double Wheel Hoe No. 13. Price $\$ 9.00$.

PLANET JR. No. 66 SLIDE HOE,-Equipped with one pair 4 in. hoes and one pair 6 in. hoes. Works between or straddle the rows.

Price $\$ 5.50$

\section{No. 8 "Planet Jr." All Steel Horse Hoe and CuItivator}

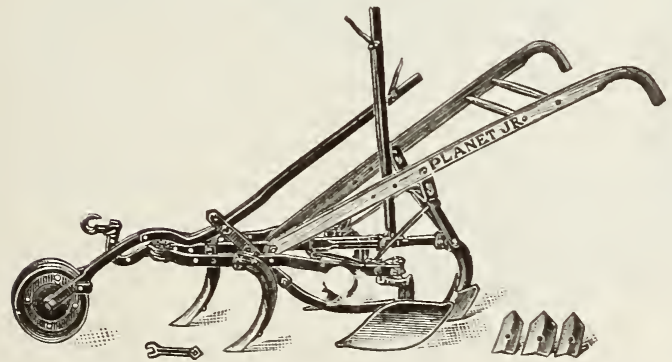

Probably no other cultivating machine is so widely known as the "Planet Jr." Combined Horse Hoe and Cultivator, it is built extra long, high and strong, has lever for adjusting width, lever for adjusting wheel, which at the same time adjusts the New Depth Regulator. This prevents cultivator settling at the back end.

Price complete as shown with new steel wheel, $\$ 20.00$.

\section{"Planet Jr." Harrow and Cullivator}

Price complete, No. 90, $\$ 20.00$. Price less pulverizer, No. $90 \mathrm{~B}, \$ 16.75$. Price plain with No. 9 wheel and expanding lever, No. $91, \$ 15.00$.

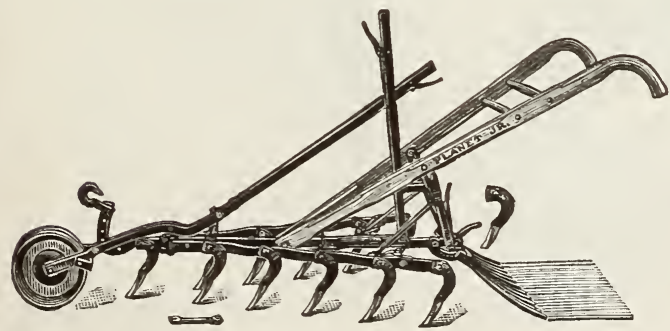

A glance at this cut will convince you that this is a thoroughly practical tool; it is what is called a Harrow, Cultivator and Pulverizer. The handles are adjustable sideways so that you need not walk on the finished work. It is adjustable from 12 to 32 inches in width, and is a special favorite with market gardeners. 


\section{ALL STEEL HORSE HOE AND CULTIVATOR}

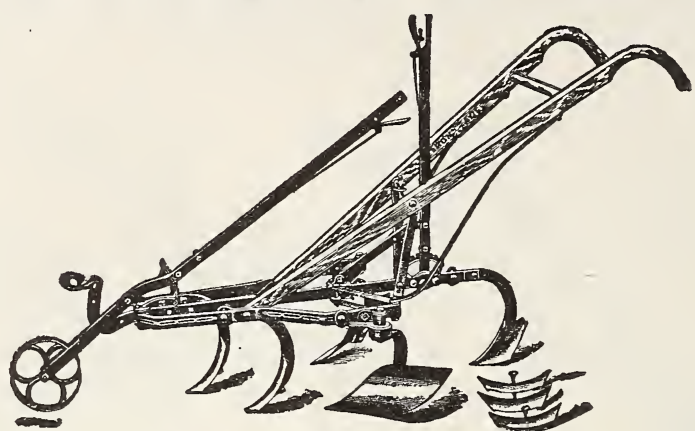

This is a good implement, not our best but a very good one for little money. (All steel but the handles.)

Price complete with hilling wings, but without wheel lever $-{ }_{-}-{ }_{-}-\$ 10.50$

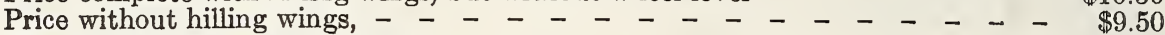

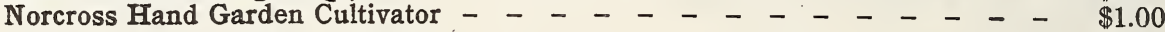

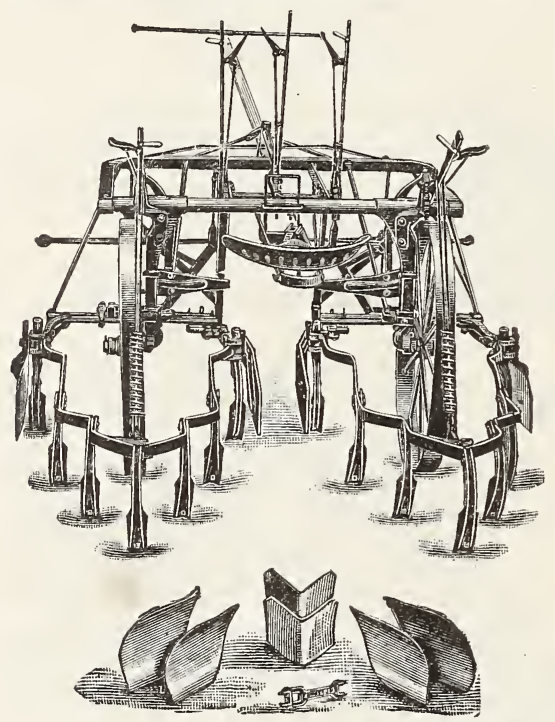

\section{"Planet Jr." No. 72, F. Two Row Pivot Wheel Cultivator, Plow, Furrower and Ridger, with Spring Trip Standards}

This tool is so designed that the operator can make changes in width of gauge instantly while machine is in motion, thereby adjusting it perfectly to rows varying greatly in width. Think of the saving in cultivating perfectly two rows of potatoes, beans, corn, or any crop planted in rows (any widths from 28 inches to 44 inches apart) at a single passage. It is a remarkably good tool.

Price Complete with (14) Spring Trip Standards,

$\$ 145.00$

Price without Spring TripStandards, $\$ 125.00$

\section{WIARD ADJUSTABLE WEEDER}

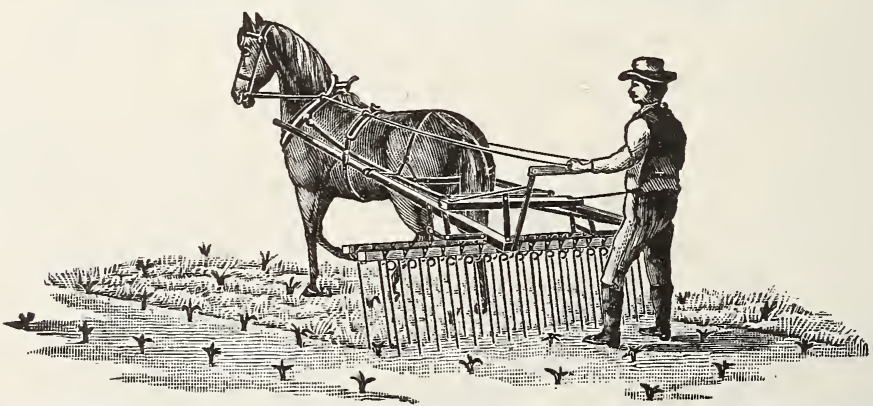

Probably as good weeder as there is made, strong, capable of many adjustments, universally liked if used as intended.

PRICE, \$15.00. 


\section{THE IRONAGS POTATO PLANTER}

With the IRON AGE, the farmer has the comfortable assurance that his potatoes are being well planted, and the work is being done at the lowest possible cost, easily planting from four to seven acres per day.

PRICE-With Fertilizer distributer and shield plow,

$\$ 145.00$

Corn, Bean and Pea attachment, extra, 9.00

Leveller attachment, extra,

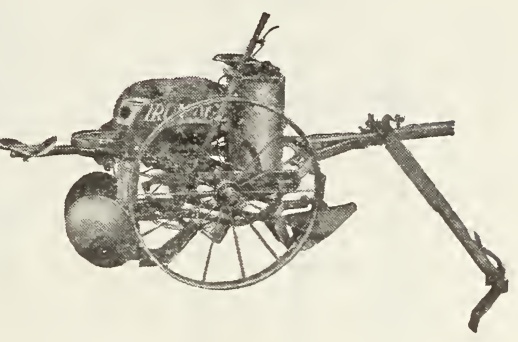

\section{IRON AGE POTATO DIGGER}

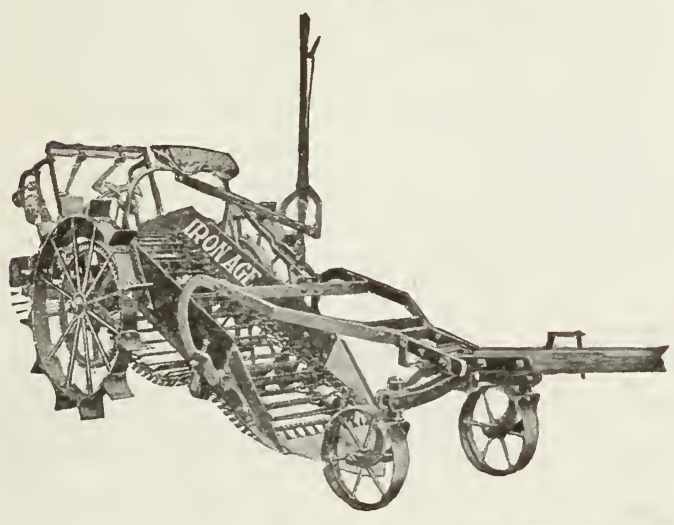

A practical digger, working well in almost all kinds of soil where it is reasonably free from weeds and grass, in fact working well under many unfavorable conditions where other diggers fail.

No. 155 Elevator Potato Digger with 4-horse equipment, $\$ 165.00$ Extra for 3-horse Equalizer (less doubletrees),

Extra for 3-horse Equipment Complete, with Double-trees,

\section{FARMOGERM}

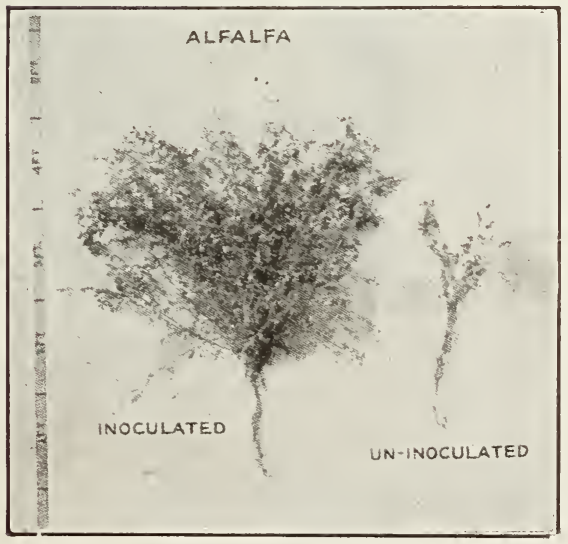

Farmogerm is nitrogen-fixing bacteria bred up to transform large amounts of nitrogen from the air into soluble nitrates.

Price Garden size, 1-4 acre, .50

“ One Acre size, $\$ 2.00$

" Five acre size, $\quad 7.50$

“ All Crop Garden size, $\quad .75$ 
The MODEL Extension Carnation Support. Patented

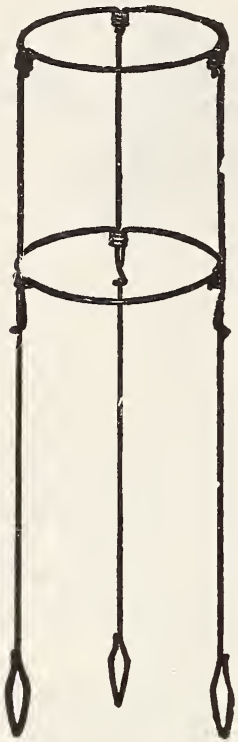

BAMBOO CANES, $-6 \mathrm{ft}$. long, $\$ 1.75$ per $100 ; 8 \mathrm{ft}$. long, $\$ 3.50$ per 100 .

STAKIS, SQUARE, GREEN, TAPERING.- Hundred

$11 / 2$ feet $\ldots \ldots \ldots \ldots 3 \mathrm{c} \ldots \ldots . \quad 25 \mathrm{c} \ldots \ldots . \quad \begin{array}{r}\text { Euch. } \\ \$ 1.50\end{array}$

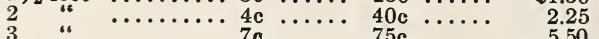

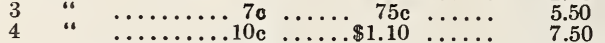

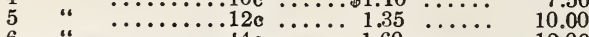

6 “ $6 \ldots \ldots 14 \mathrm{c} \ldots \ldots 1.60 \ldots \ldots, 1200$ STAKES, ROUUND, GREEN, $\underset{\text { Doz. }}{\text { GRING,- Hundred }}$ 2 feet $\quad \ldots \ldots \ldots \ldots 5 \mathrm{c} \ldots \ldots .50 \mathrm{c} \ldots \ldots . \quad \$ 2.50$ “ $\quad \cdots \cdots \cdots, 7 \mathrm{c} \ldots \ldots, 75 \mathrm{c} \ldots \ldots . \quad 5.00$ STAKES ÖR DAHLIA PÖLS, HEAVY ROUND, 5 feet $\ldots \ldots \ldots \ldots 15 \mathrm{c} \ldots \ldots . \$ 1.50 \ldots \ldots{ }^{\text {Hundred }}$

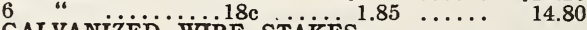
GALVANIZ̈E WiRE STÄKES,- Hundred

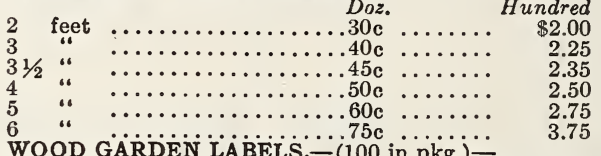
WOOD GARDEN $\mathrm{LABELS},-(100$ in pkg.) 8 inch per hundred, "Painted, $75 \mathrm{c}$ WOOD POT LABELS, $-(1000$ in pkg. $)-$ Painted, $\$ 1.20$ WOOD TREE LABELS, - 3 i $1 \%$ in. copper wired, $35 \mathrm{c}$ per 100; $\$ 2.50$ per 1000 .

FLOWER STEMS,-(Wired Tooth Picks), per box of $10,000, \$ 2.00$.

CARNATION SUPPORT,-“Model Extension." 2 ring, per doz., $85 \mathrm{c}$; per $100, \$ 6.00$; 3 ring, per doz., $\$ 1.00$; per $100, \$ 6.50$

TOMATO SUPPORT, Price $30 \mathrm{c}$ each, per doz., $\$ 3.00$

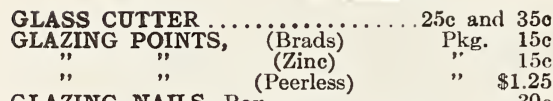

GLAZING NAILS, Box...............30

GARDEN REELS, large $\$ 1.00$, extra large. . .\$1.50 GARDEN LINES, $(100 \mathrm{ft}.) \ldots \ldots \ldots \ldots \ldots \ldots$
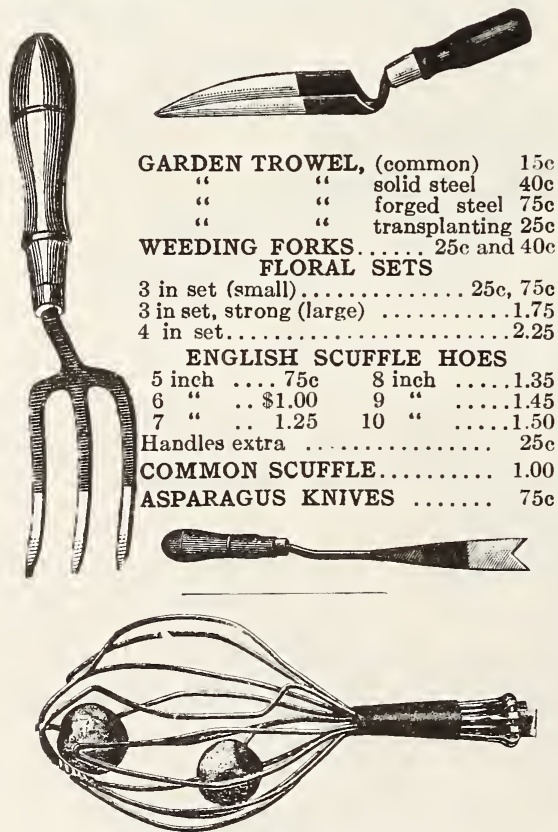

FRUIT PICKERS (wire) 50c

\section{THERMOMETERS}

Tested, 12 inch, metal case $\$ 1.50, \$ 2.00$ and $\$ 2.25$ 10 inch tested ...........90, $\$ 1.25$ and $\$ 2.00$ 8 " " $\ldots \ldots \ldots .90, \$ 1.00, \$ 1.25$ and $\$ 1.75$ Hot Bed, guaranteed . . . . . . . . . . . . . $\$ 2.50$ Maple Syrup................. $\$ 1.50$ and $\$ 2.50$

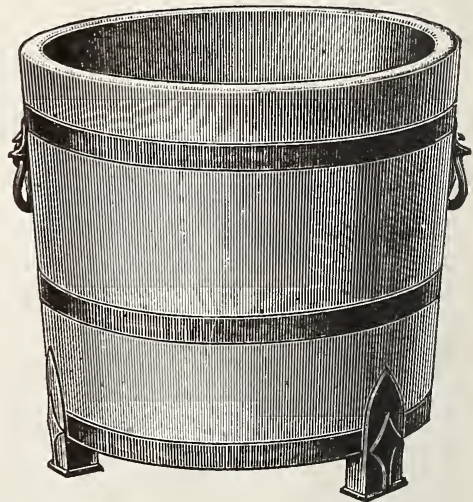

TREE TUBS-New York Pattern

Made of Virginia White Cedar, painted green.

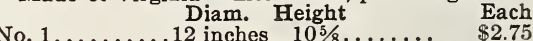

“ $2 \ldots \ldots \ldots \ldots 13$ inches $123 / \ldots \ldots \ldots \ldots$. $\$ 2.25$

“ $2 \ldots \ldots \ldots 13$ " $123 \ldots \ldots \ldots . \quad 3.25$

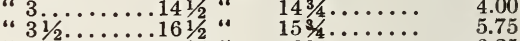

“ $4 \ldots \ldots \ldots \ldots 1912$ “ $165 . \ldots \ldots \cdots, \quad 6.25$

“ $5 \ldots \ldots \ldots .221 \frac{1}{2}$ “. $181 \frac{1}{2} \ldots \ldots \ldots, \quad 7.25$

HAND WEEDERS-10c to $40 \mathrm{c}$. 


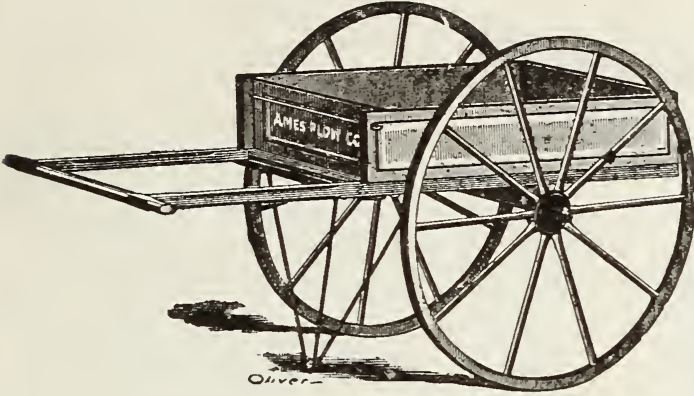

\section{HAND CARTS}

Light, strong, well made. The No. 10 and No. 12 have bent handles. No. 14 has straight handles as illustrated.

Price

No. 10.-Wood Wheels, Body $37 \times 22$ in. $\$ 15.50$

No. 12.-Wood Wheels, Body $41 \times 25$ in.

$\$ 18.00$

No. 14.-Wood Wheels Body $44 \times 30$ in.
$\$ 20.00$

\section{SPECIAL LAWN CART}

Body 41 in. x 25 in. Steel axles Removable Leaf Rack 16 in. high. Tire $2 \frac{1}{2}$ inches.

CUT FLOWER VASES FOR CEMETERY

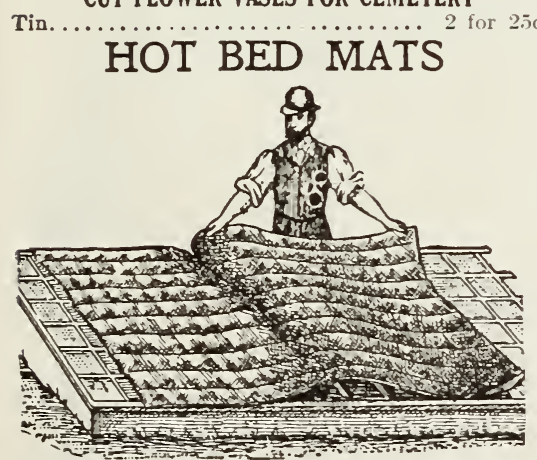

Made of Jute, thickly padded. $76 \times 76$ in. Price es. $\$ 4.00$ Improved Mole Trap,................\$1.75 Pruning Shears, 7 in. light Steel........... $75 \mathrm{c}$

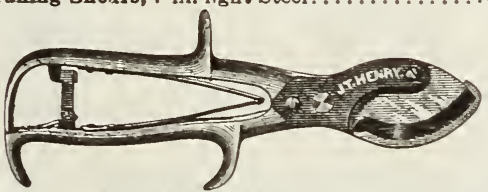

Pruning Shears, 8 in. steel..............65

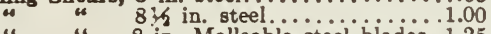
“ " 8 in. Malleable steel blades, 1.25 “ “ French. \$1.25, \$1.50, \$2.25, \$3.00 Flower Picking Shears (nickled), $\$ 1.25$ and $\$ 1.50$ Grape Thinning Shears....... \$1.50 and 1.75 Grass or Sheep Shears $50,75, \$ 1.00, \$ 1.25, \$ 1.50$

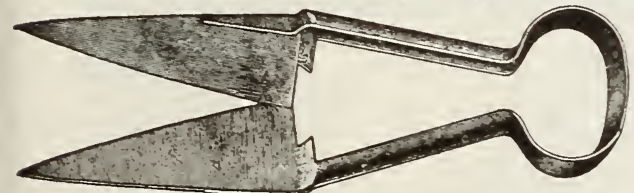

True Vermonter Shears.... \$1.25, $\$ 1.50$ and $\$ 2.25$ PRUNING 'KNIVES.

English Stag Horn...........\$1.75 and $\$ 2.25$

Cocobolo...... $\$ 1.50$ BUDDING KNTVES

Ivory Handle............. \$2.00, $\$ 2.25, \$ 2.50$

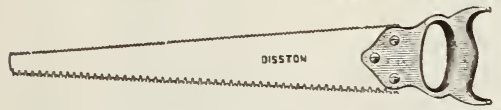

PRUNING_SAW, (double edge) .......\$1.25, $\$ 1.50$

Price $\$ 28.00$

WATER'S TREE PRUNER 4 feet $\ldots \ldots \ldots \ldots \ldots \$ 11.00$ 4 feet $\ldots \ldots \cdots \cdots \cdots \cdots \cdots \times 1.00$ $8 \quad$ " $\cdots \cdots \cdots \cdots \cdots \cdots \cdots \cdots \cdots$ $100 \ldots \ldots \ldots \ldots \cdots, 1.50$ $12 " \ldots \ldots \ldots \ldots \ldots, 2.00$ Extra Knives ...........25 Giant Pruner, Saw and Pruner Combined........... $\$ 2.25$ Orchard Pruner-plain...\$2.00 TREE SCRAPERS .......85c

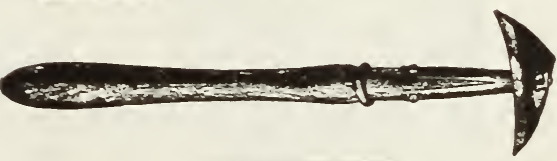

Sand Riddles for Sifting Soil 18 in. Galvanized either $1 / 4$ inch, $1 / 2$ inch, $3 / 4$ inch or 1 inch, each $\$ 1.00$.

\section{RUBBER PLANT SPRINKLER}

Medium size.... \$1.00 Large size....... 1.25

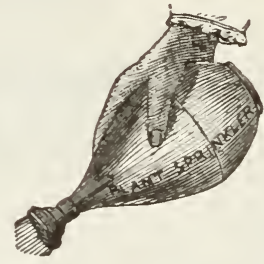

MASTICA,-Used in place of Putty.

$1 / 2$ gallon can, \$1.00; 1 gallon can........\$2.15 MASTICA MACHINE ................ PUTTY BULB - for glazing ............. 1.25

TARRED MARLINE $\rightarrow$ for making straw

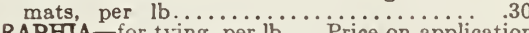
RAPHA - for tying, per lb... Price on application WOOL TWINE - soft, for tying, per lb...... .30 SHKALINE-green, per spool.................... GREEN FLORIST'S TWINE-per ball..... .10 COARSE TWINE-Hemp, very strong, per

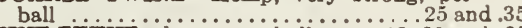
FINE TWINE-hemp, per ball....... 12,20 and .25 COTTON TWINE - por ball. ............ .15 GALVANIZED ANNEALED GREENHOUSE

WIRE - per lb . . . .

MOSS (Sphagnum) - -ither dry or iresh- green, per bbl.............. $\$ 1.50$ to 3.00 CORN KNIVES ................. 30 c, $50 \mathrm{c}$ and $75 \mathrm{c}$ GRASS HOOKS-Common..........35c to $45 \mathrm{c}$ " English and Concave ......750 TIN FOIL-Plain....................... 


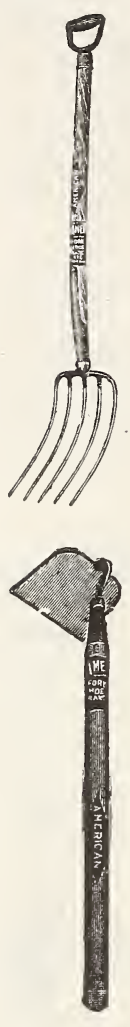

\section{HAY FORKS \\ "BATCHELLER'S"}

No. 0, 3 Tine (boys') straight handle $85 \mathrm{c}$ No. 3,3 Tine bent handle...... $\$ 1.00$ The above prices are for forks with $33 / 4 \mathrm{ft}$., $4 \mathrm{ft}$., and $41 / 2 \mathrm{ft}$. handle.

Extra long handles, $15 \mathrm{c}$ extra.

\section{HOES}

Socket Field, 8 in. biade...... 90

Shank Field, $71 / 2$ and 8 inch blade $75 \mathrm{c}$ Socket, Meadow, 9 and 10 inch.. 1.00 Ladies' Hoe, $51 / 4$ inch blade..... $70 \mathrm{c}$

Humphrey (tooth hoe) ....... $\$ 1.15$

Warren Hoe............... 1.00

Mortar Hoe (shank) ........... 1.10 (socket) $\ldots \ldots \ldots \ldots 1.15$

\section{RAKES}

Steel Garden

is

"،

Steel Short Teeth ...........

Steel Heavy Road ...........14

Electric Welded ...............

TURF EDGER-or Edging Kंnife

\section{RULES}

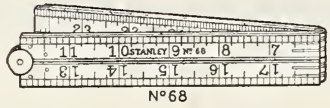

1 foot Caliper........35c and $40 \mathrm{c}$

2 " Plain ....................

2 " (heavy joint)................

2 “ Half Brass Bound......50

Full "

FILES

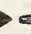

ALL SIZES-Taper, Slim Taper and Flat Files. LEVEIS

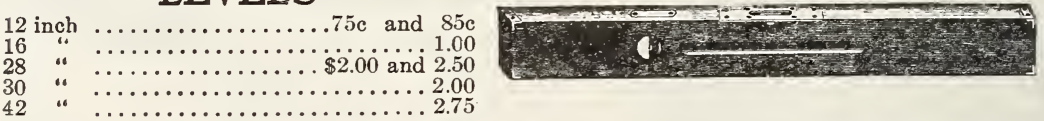

$\$ 0000000$

\section{BIT BRACES}

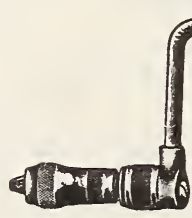

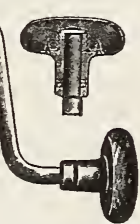

$\$ 1.25$

\section{Plain}

Ratchet..........

Putty Knives................... 35 c and 50 c

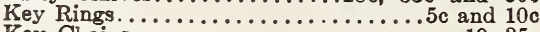

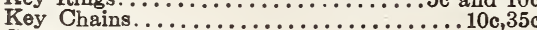

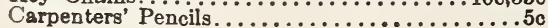

SPAD ING FORKS- "Batcheller's"

4 Tine Long Handle, Flat or Diamond

Tine............... \$1.25

4 Tine D Handle, Flat or Diamond

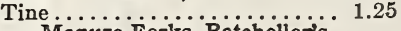

4 Tine Long or D Handle,

$\begin{array}{llllll}5 & \text { " “ } & \text { " } & \text { " } & 1.40\end{array}$

Potato Digging Fork ........... 1.80

Potato Hooks, Batcheller's. 5 Tine "Standard,"

1.00 6 " " . . . . 1.10 Barl ey Forks (with bail) ........ 2.00

Ensilage Fork, 8 tines ......... 2.00

Coke Fork, 12 tines............ 2.75

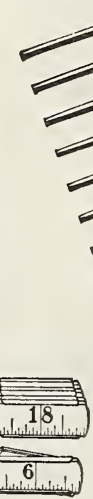

3 foot Zig Zag...........40c

4 " 4 " $\ldots \ldots \ldots \ldots \ldots .45 \mathrm{c}$

5 " $\quad$ " $\quad \ldots \ldots \ldots \ldots \ldots \ldots .6 .60 \%$

6 " " $6 \ldots \ldots \ldots \ldots 6 . \ldots 6$

\section{GLUE}

\section{LePAGE'S}

Small Bottle............. 10c

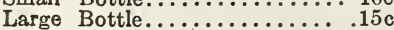

Large Bottle............. $15 \mathrm{c}$

0

75




\section{HATCHETS}

Shingling............ $\$ 1.75$ and $\$ 2.00$ Broad............. $\$ 1.65, \$ 1.75$ and $\$ 2.00$ Funter's............... $\$ 1.10$ and $\$ 1.35$ House Axe............\$1.25 and $\$ 1.50$ Lathing........................ $\$ 1.50$
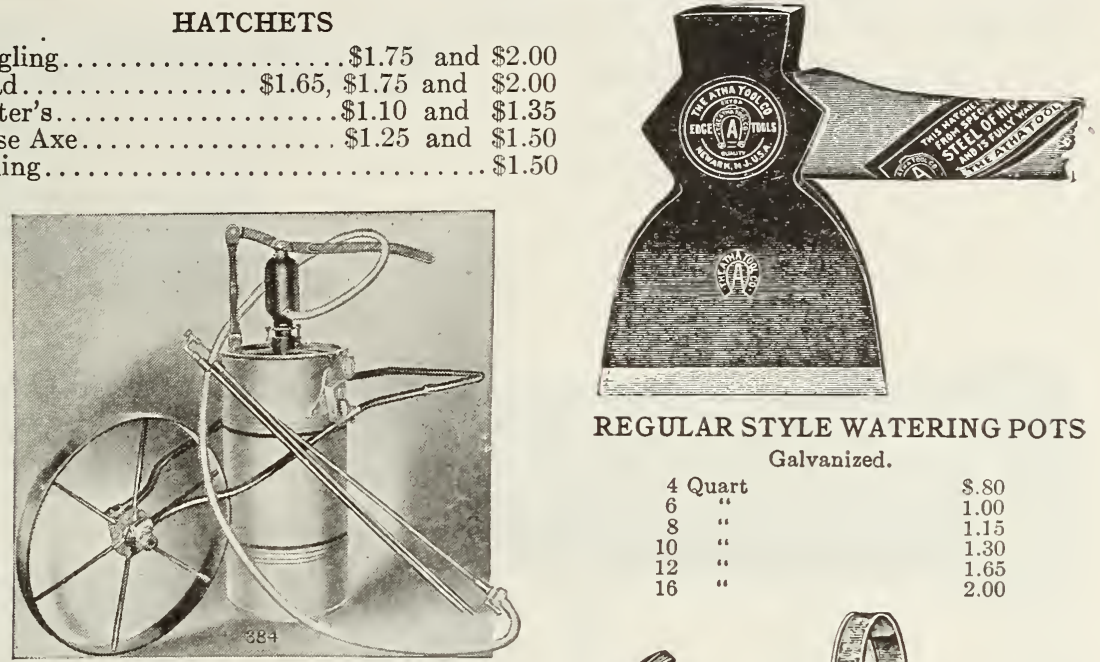

REGULAR STYLE WATERING POTS Galvanized.

AUTO SPRAY NO. $40 \mathrm{D}$

With 12 gal. galv. steel tank with truck 20 in. wheel.

For applying whitewash, cold water paint spraying material, etc. Price $\$ 20.00$.

\section{KNAPSACK SPRAYER NO. 5}

With double acting pump,. Price $\$ 8.00$.

PHILADELPHIA WATERING POTS

Made of very heavy galvanized iron, with brass joints, with two copper roses and extra long spout. 6 Quart, \$3.25. 8 Quart, \$3.75 10 Quart, \$4.25.

\section{FRENCH PATTERN WATERING POT}

6 Quart, Galvanized, 8 Quart, Galvanized, - $\quad$ - $\quad$ - 4.00

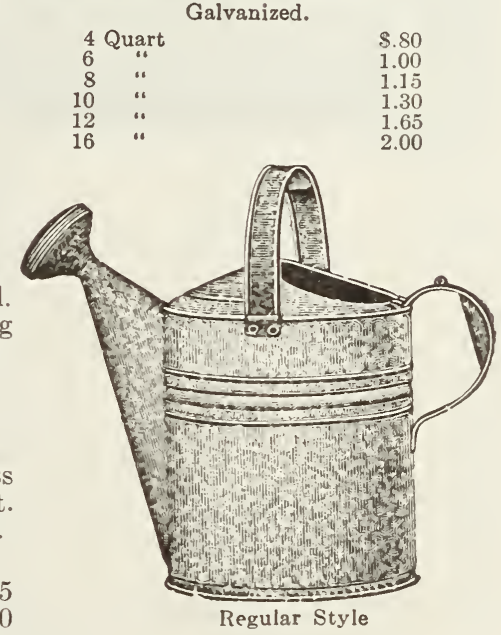

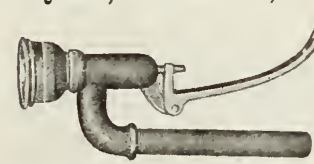

Auto Pop Nozzle

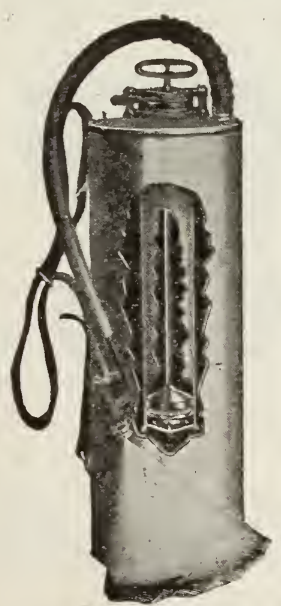

Auto Spray Pump 3
A AUTO POP NOZZLE, $\$ 1.75$

- $\quad$ - $\quad-\quad \$ 3.75$

with hose complete $\$ 2.25$

Brass extension pipe 2 foot length, $75 \mathrm{c}$

\section{AUTO SPRAY PUMP}

Self-operating Sprayer, simple, durable, easy to carry and operate. Price with Brass Tank and Auto Pop Nozzle, \$10.00; with Galvanized Tank and Auto Pop Nozzle, \$7.00.

\section{FLOWER BED GUARD}

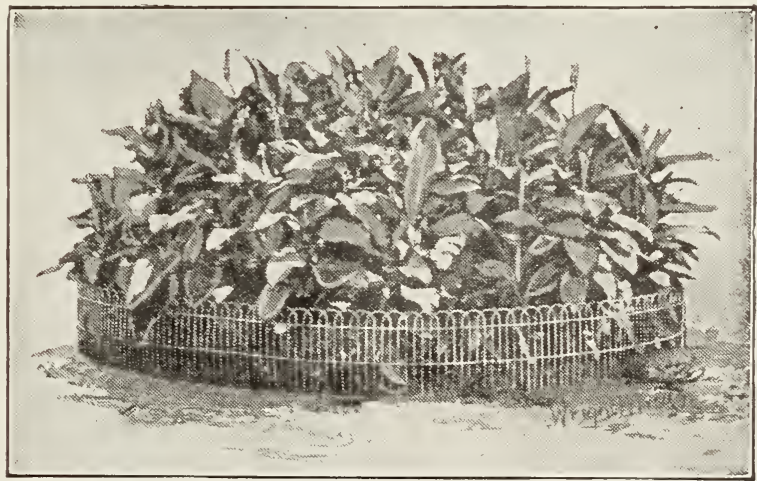

Made of heavy galvanized wires, 15 in. high, 12 when set, Per lineal ft. $13 \mathrm{c}$

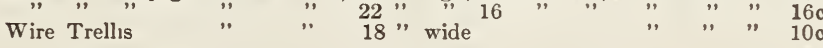




\section{ROUND OR HEXAGON LAND TILE-(13 Inches long)}

\section{ROUND TILE}

The sizes named are inside measurements.

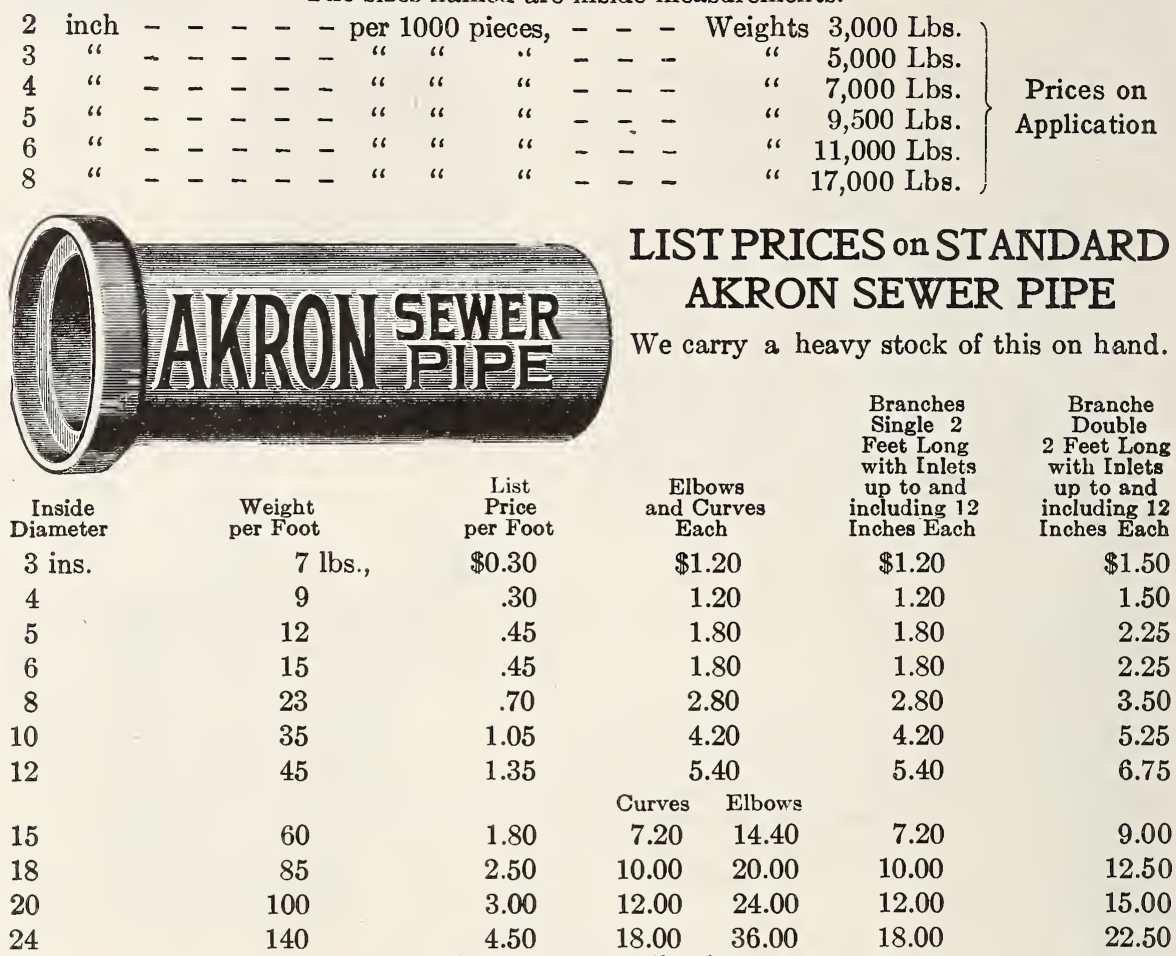

Discount on Application.

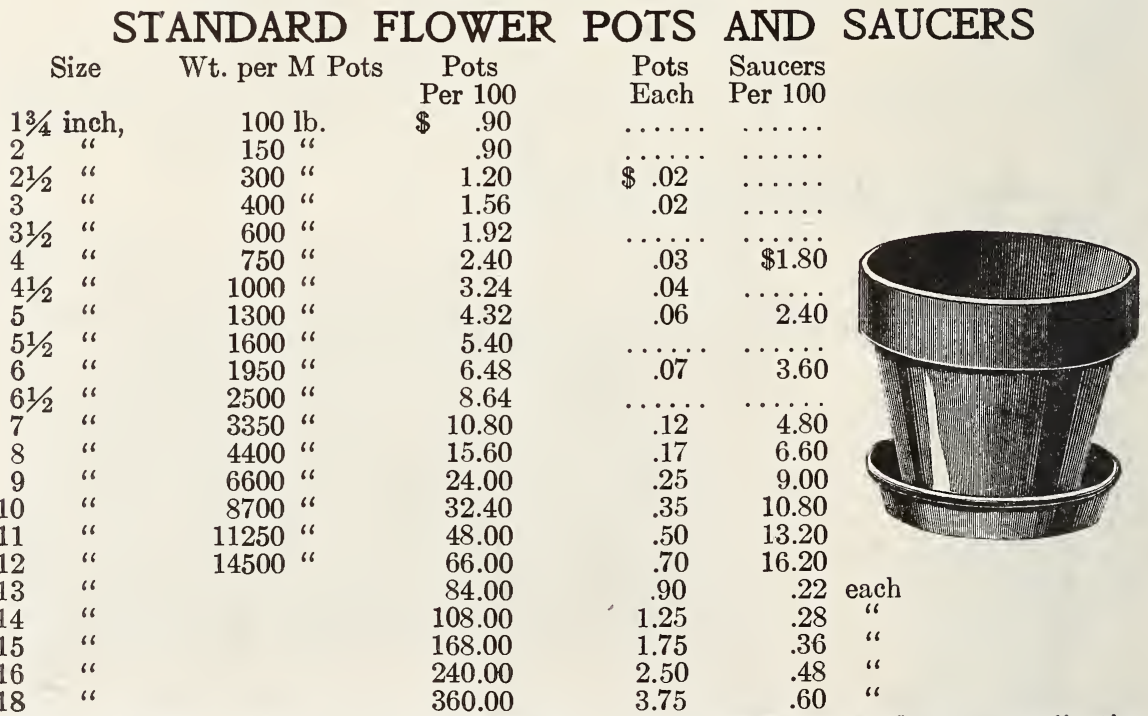

We are prepared to give you the right figures on first-class Earthen Ware, on application. 


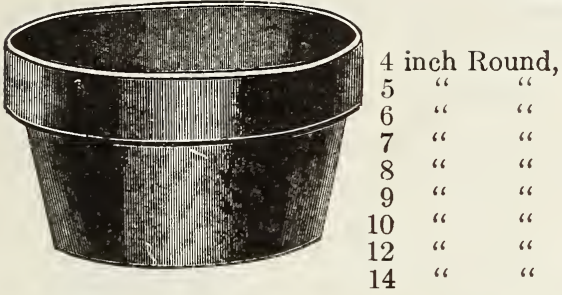

FIRE CLAY FLUE LINING 2 FOOT LENGTHS Openings and Register 50 per cent added. * Sizes most used.
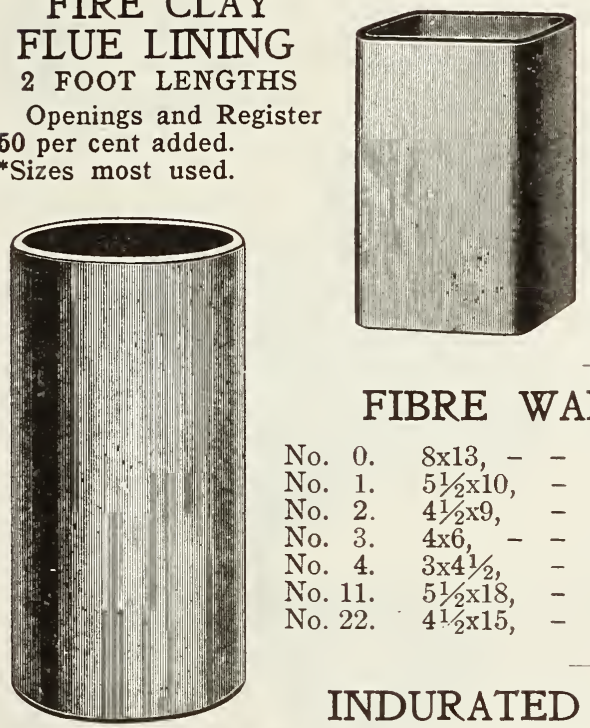

Outside Measure. Weight. List Price per $\mathrm{ft}$. $41 / 2 \times 81 / 2$ in. ....14 lbs. ..... .45 $41 / 2 \times 13$ " $\ldots \ldots 20$ " $\ldots . \ldots . .60$ $41 / 2 \times 18$ " $\ldots \ldots .40$ " $\ldots \ldots \ldots \ldots . . .20$

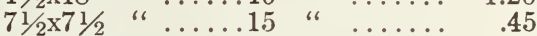
* $81 / 2 \times 81 / 2$ " $\ldots . .20$ " * $81 \frac{1}{2 \times 13}$ " $81 / 2 \times 18$ " $\ldots \ldots .45$ " $\quad \ldots \ldots \ldots .41 .35$

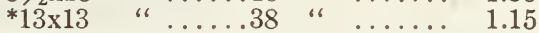
$13 \times 18$ " $\ldots \ldots .57$ " $\ldots \ldots \ldots .7 .75$ $18 \times 18$ " $\ldots \ldots 72$ " $\ldots \ldots \ldots .25$

\section{FIBRE WARE-FLORISTS' VASES}

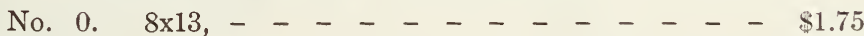

No. 1. $51 / 2 \times 10, \quad-\quad-\cdots+-\cdots$

No. 2. $41 / 2 \times 9, \quad-\ldots-\ldots-\ldots$

No. 3. $4 \times 6, \quad-\ldots+\ldots$

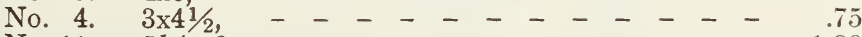

No. 11. $51 / 2 \times 18, \quad-\quad-\ldots+\ldots$

No. 22. $4 \frac{1}{2} \times 15, \quad-\quad-\ldots+\ldots$

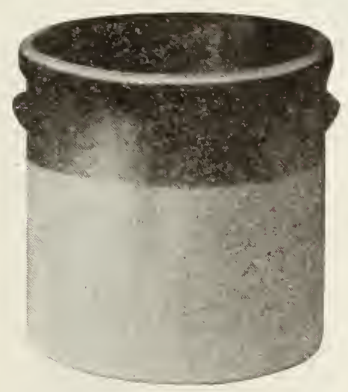

INDURATED FIBRE WARE SAUCERS WILL NOT SOAK WATER

$\begin{array}{lcc}5 \text { inch, } & \text { Each } & \text { Doz. } \\ 6 \text { “" } & 34 & \$ 3.96 \\ 8 \text { " } & 35 & 4.14 \\ 10 \text { inch, } & 50 & 4.68 \\ 12 \text { " } & 50 & 5.56 \\ 14 \text { " } & 75 & 6.60\end{array}$

\section{CROCKS OR STONE JARS}

For Butter, Meat, Pickles, etc. Large Stock in the following sizes:

1 gal., 2-3-4-5-6-8-10-12-15-20-25 and 30 gal. - Prices on application

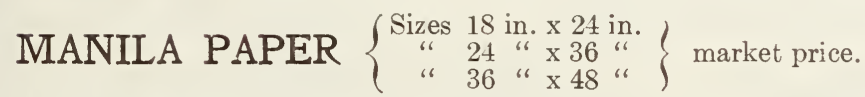

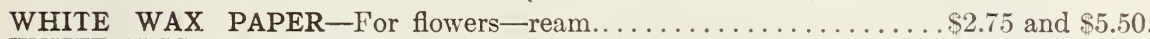
WHITE TISSUE PAPER_For " " GREEN TISSUE PAPER-For " "

\section{STOVE LINING}

Made of fire clay, to take the place of stove brick. Per Pkg........25c, 45c and 60c

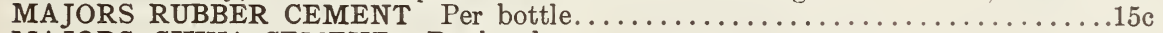

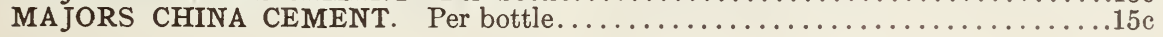




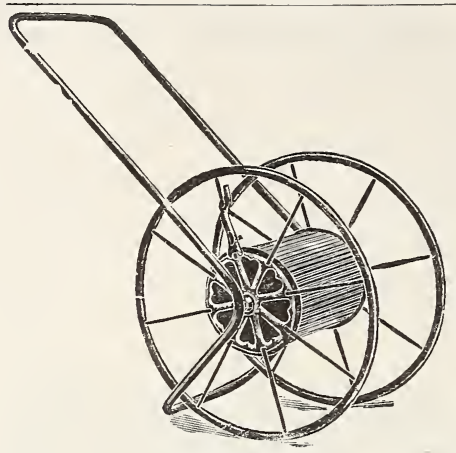

\section{The "B\&S" Hose Reel}

A very satisfactory reel.

Price $\$ 3.25$

Tubular Hose Reel

\section{RUBBER HOSE}

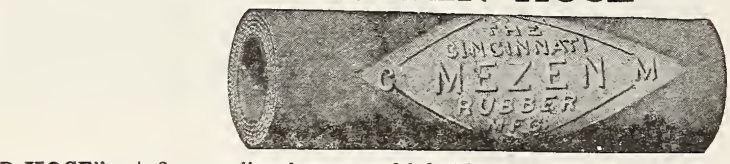

Eclipse Hose ReeI

Price $\$ 1.50$

\section{Tubular Iron HoseReel}

Light weight, high wheels.

For $100 \mathrm{ft}$. Hose, \$5.50.

For $150 \mathrm{ft}$. Hose, $\$ 6.50$.

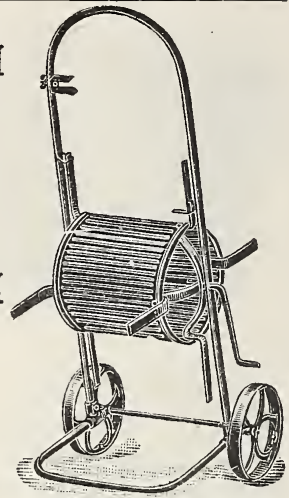

B \& S Hose Reel

"MOLDED HOSE"-A fine quality hose non-kinkable, very pliable, especially good for tree spraying and Howreenhouse use, $\frac{5}{8}$ in., $21 \mathrm{ct}$. and $25 \mathrm{c} \mathrm{ft}$.

HOWARD'S “B. \& S." 5 Ply - An excellent hose. 1/2 in.. 19c., 3/4 in., 20c

"Ply mouth"-Good Hose for the money, $1 / 2$ in. coupled, per ft., $16 \mathrm{c}$.; $3 / 4 \mathrm{in}$., coupled, $18 \mathrm{ct}$.

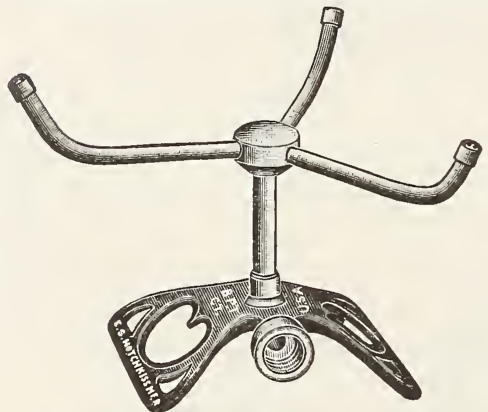

Lawn Sprinkler, Fig. 35, \$1.65

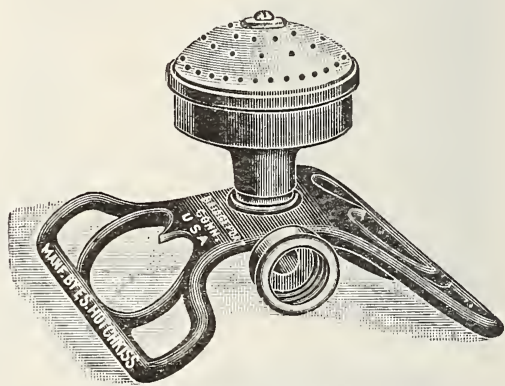

Lawn Sprinkler, Fig. $20 \$ 1.90$

LAWN SPRINKLER. - Similar to Fig. 35 but with longer arms and higher standard,

LAWN SPRINKLER, No. 65-B,-Has revolving arms and rose spray,

HOSE COUPLINGS-Complete set,

"Bands and Clamps, each,

" Menders "Cooper's," $3 / 4$ in., $1 / 2$ in., each 120 ;

“Washers, per dozen,

" Pliers,

“ Nozzle Holders

“ End for connecting hose with faucet,

" Perfect Clinch Mender, each,

HOSE NOZZLE,-Throws spray or solid stream by turning thumb screw. MISTRY NOZZLE, - for $1 / 4$ in. pipe, $\$ 2.00$; for Hose

MISTRY JR. NOZZLE,- for 1/4 in. pipe, \$1.00; for Hose,

COUPLING to connect Hose with $1 / 4$ in. extension pipe,

VERMOREL SPRAY NOZZLE,-

KINNEY PUMP -

ROSE SPRAY NOZZLE,-

Chisel Blade Weed Cutter, with Foot Rest,

Pastime Weed Extractor, with $4 \mathrm{ft}$. handle,

\section{BRASS PLANT SYRINGES.}

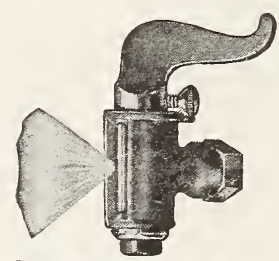

Bordeaux Nozzle, $\$ 1.25$

No. " $H$ " Barrel 16 in. long, 1 1-2 in. in diam.

No. " $G$ " Barrel 16 in. long, 1 spray, 1 stream Rose,

No. 6. 1 Rose and Angle Joint,

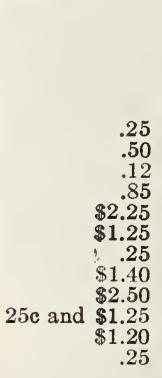

$\$ 1.90$

\section{WATER BARREL AND TRUCK}

Complete with $21 / 2$ inch tire, TRUCK without barrel.
Price $\$ 22.00$

“ $\quad \begin{array}{r}18.00 \\ \end{array}$

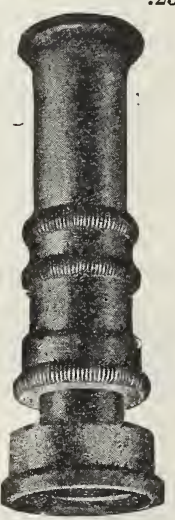

Boston Hose 


\section{COLDWELL IMPROVED LAWN MOWER}

Coldwell's "limproed"

A Splendid Machine. It is provided Horse Lawn Mower

with shafts, seat and side draft attachment. Each mower is guaranteed to give complete satisfaction. The new lever attachment for raising knives from the ground and adjusting heights of cut is very convenient. Price: 30 in., \$88; 35 in., \$110; 40 in., \$136.

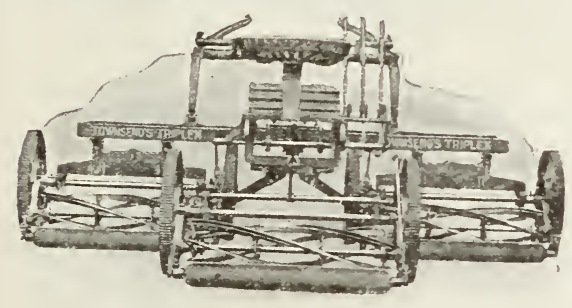

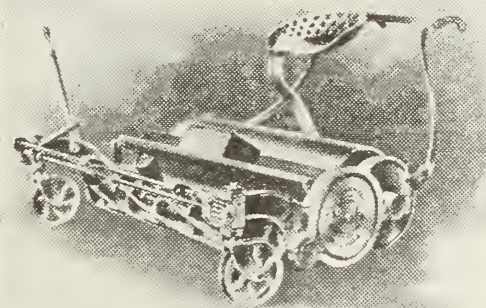

TOWNSEND'S TRIPLEX HORSE LAWN MIOWER

THE TRIPLEX, consists of three lawn mowers yoked together, two abreast and one following in the center, easily drawn by one horse and cuts a swath over seven feet wide-conforms itself to uneven surfaces, does good and very rapid work. Price complete $\$ 300.00$ f. o. b. New York.

VICTORY BALL BEARING LAWN MOWER

Light, easy running, a beauty, 16 in., $\$ 15.00$; 18 in., $\$ 17.00 ; 20$ in., $\$ 19.00$.

\section{IMPERIAL HIGH WHEEL LAWN MOWER}

This mower is not surpassed by any Lawn Mower in the market. It is easy running, does the best of work, and its construction is such that it will outwear any lawn mower made.

Price: 16 in., $\$ 15.00 ; 1$ in., $\$ 16.00$., 20 in., $\$ 18.00$.

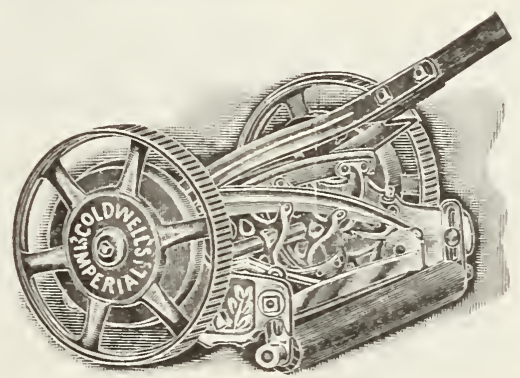

\section{THE CADET LAWN MOWER}

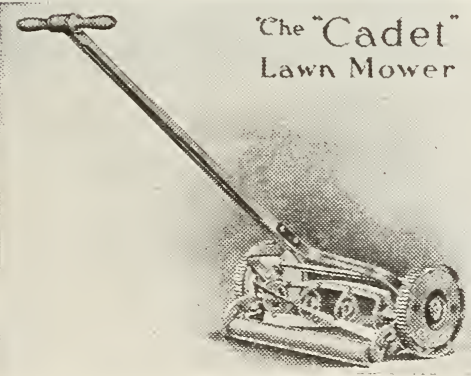

This is an excellent low price mower and should not be confounded with the cheap mowers that are on the market, many of which are worthless.

The Cadet is a well made, substantial mower,

Price 14 inch,

Price 16 inch, 


\section{GREAT AIMERICAN BALL BEARING}

The most imitated and the best of its class, 101/2-inch Wheel, 5-blade cylinder.

\section{5 -inch $\$ 18.50 \quad 19$-inch $\$ 23.00$ 17-inch $\quad 20.50 \quad 21$-inch $\quad 25.00$}
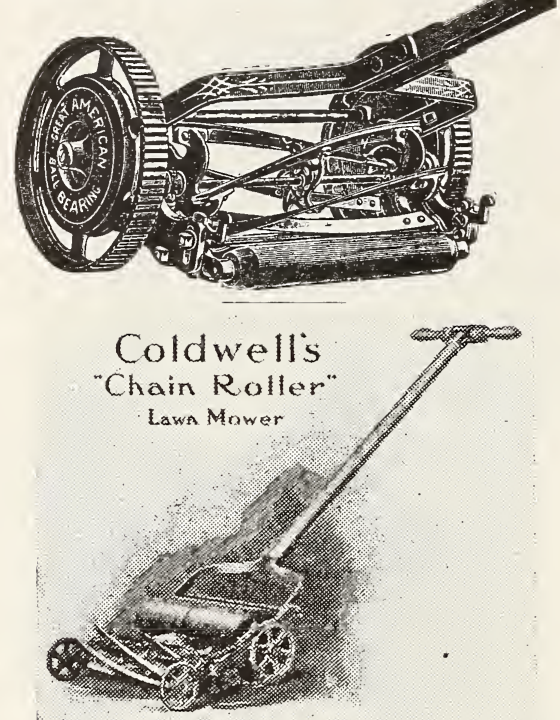

PRICE-4 Blade Mower, 12 in. $\$ 18.00$;

\section{THE NEWPORT HIGH WHEEL MOWER}

A medium-priced mower and a splendid machine.

16 inch, $\$ 9.50$

\section{CHAIN OR GEARED ROLLER IMOWER}

These are designed especially for use on borders and on the edges of drives and walks.

They run very easily and are quite a necessity an all large lawns.

\section{4 in. $\$ 20.00 ; \quad\} \begin{aligned} & \text { Add } \$ 3.00 \text { for } \\ & \text { Grass Catcher. }\end{aligned}$}

\section{THE NORKA LAWN MOWER}

This mower is what might be called a bargain mower, it is worth much more than the price asked. 16 inch only, $\$ 6.85$.

GRASS CATCHER for high wheel mowers, $\$ 2.50$ each.

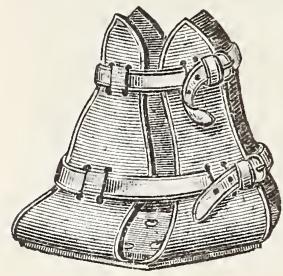

HORSE IAWN BOOTS

To prevent horse from marking the lawn.

Price per set of 4 $\$ 12.00$ and 14.00

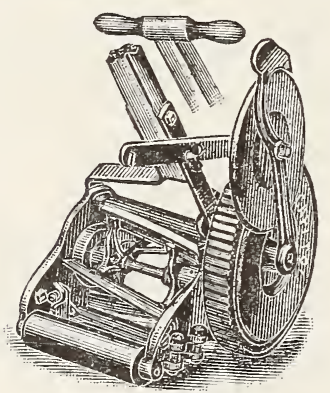

Capital

Lawn

Edger and Trimmer

For cutting grass borders and trimming edges of walks.

Price complete, $\$ 8.50$.

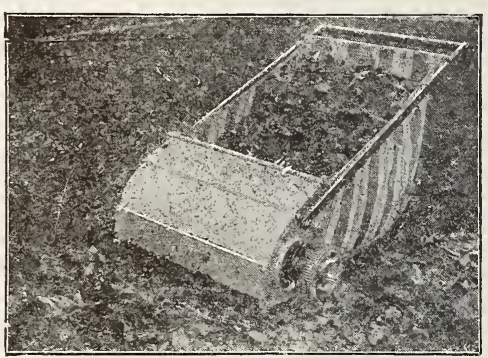

\section{THE PENNSYLVANIA LAWN CLEANER}

A revolving fan with"metal teeth, takes up leaves, dead grass, stones, etc.

Price, 24 in.

$\$ 25.00$

" 36 "

36.00 


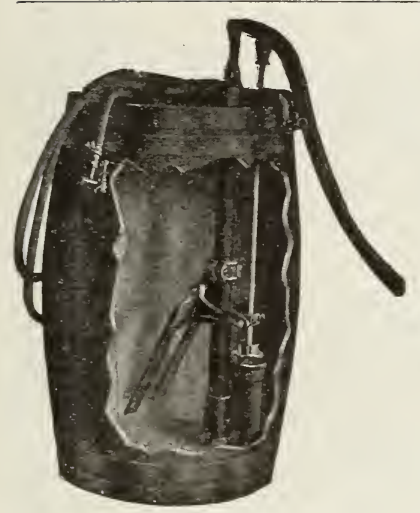

\section{POIONA SPRAY PUMP}

One of the Best Pumps for orchard use, very powerful, all working parts solid bronze.

Price pump with $15 \mathrm{ft}$. hose, "Mistry" nozzle and Agitator, fitted to barrel, $\$ 33.00$.

Price with two leads of hose, with nozzles and Agitator, fitted to barrel, $\$ 36.00$.

Gould's Cart for mounting barrel sprayers, $\$ 16.00$.

\section{"Iron Age" Four Row Traction Sprayer}

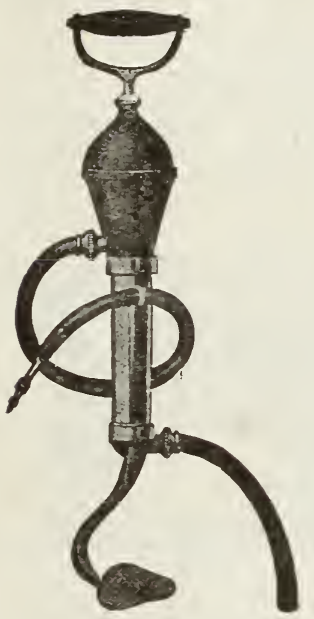

The Aquarius

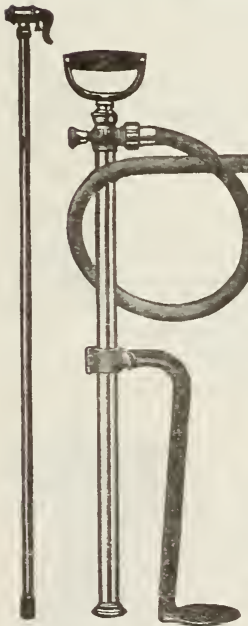

The Aquapult

A practical Sprayer operated by horse power, tank made o heavy galvanized iron, holds 55 gallons, sprays four rows at once.

Price with Pole, Duplex Pump, Win!! Shift and Nozzle Strainer, \$165.00. Extra for Drop Nozzle Spray Bar Attachment, \$27.50. Orchard attachment, extra $\$ 13.20$.

\section{THE AQUARIUS}

A very powerful little pump, throws a steady stream. Cylinder, piston rod and couplings are brass, fitted with $21 / 2 \mathrm{ft}$. suction and $3 \mathrm{ft}$. discharge pipe, one spray and one solid stream nozzle.

Price \$\$.50

\section{THE AQUAPULT}

\section{A VERY SERVICEABLE HAND FORCE PUMP}

The valyes are brass balls, which successfully resist the action of acids. Complete with $3 \mathrm{ft}$. discharge hose, solid stream and spray nozzle, Price $\$ 7.50$ With 4 foot Extension Rod and Bordeaux Nozzle, \$9.00.

THE AUTC SPRAY PUMP_-imilar to the Aruapult but smaller. \$.5.0n.

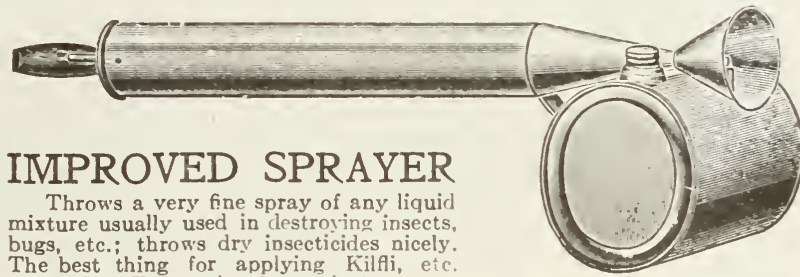

bugs, etc.; throw's dry insecticides nicely.

The best thing for applying Kilfi, etc.
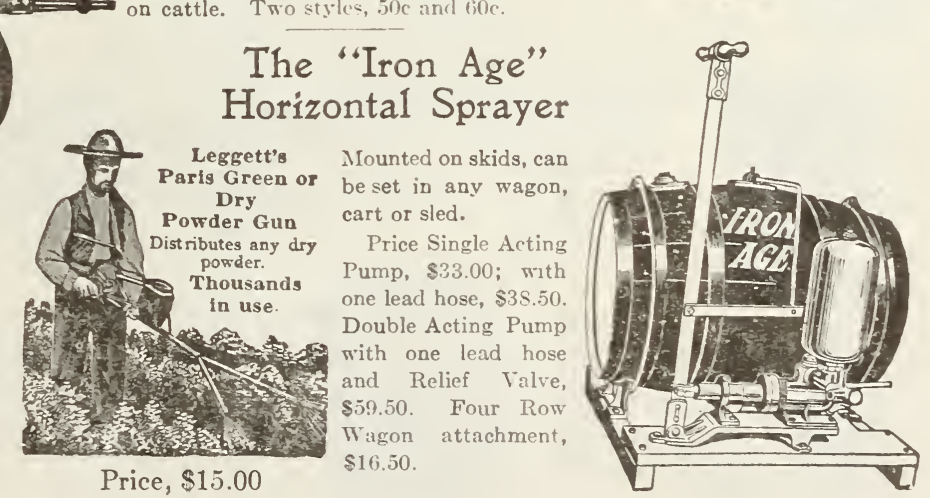


\section{INSECTICIDES}

APHINE,-For the destruction of green fly, black fly, white fly, thrip, red spider, mealy bug, caterpillars, white and brown scale. 1/4 Pt. 25c; Quart $\$ 1.00 ;$ Gallon $\$ 3.00$.

APHIS PUNK.-For fumigating Greenhouses. Three rolls will fumigate 100 foot house. One dozen rolls in box. Price per box, 65c.

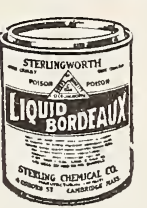

AR-BO, Sterlingworth.-Kills leaf eating insects and prevents fungus diseases. Use $1 \mathrm{lb}$. to 10 gallons water. $1 \mathrm{lb} .35 \mathrm{c}, 5$ lbs. $\$ 1.50$.

ARSENATE OF LEAD. - 1 lb. 35c., 5 lbs. $\$ 1.40$.

ARSENATE OF LEAD,-Dry. Per 1-2 lb. $35,1 \mathrm{lb} .60 \mathrm{c}$.

Bordeaux Mixture, Sterlingworth. - Prevents Potato Blight, Mildew and all Fungus growths. Dilute with 25 to 50 parts water. Qt. can, 50c; Gallon can, $\$ 1.65$.

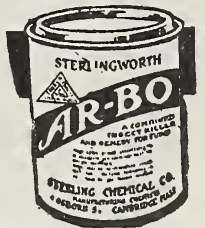

"Black Leaf 40"-A strong, nicotine preparation, for destroying aphis, thrip, etc., $1 \mathrm{oz}$. $25 \mathrm{c} ; 1 / 2 \mathrm{lb}$. can, $75 \mathrm{c} ; 2 \mathrm{lb}$. can, $\$ 2.50 ; 10 \mathrm{lb}$. can, $\$ 10.75$.

BUG DEATH.-An insecticide for destroying Potato, Squash and Cucumber Bugs, Currant Worms, etc. Price $1 \mathrm{lb}$. pkg., 25c, 3 lb. pkg. $50 \mathrm{c}, 5 \mathrm{lb}$. pkg. $70 \mathrm{c}, 121 / 2 \mathrm{lb}$. pkg. $\$ 1.50 ; 100 \mathrm{lb}$. keg, $\$ 9.25$.

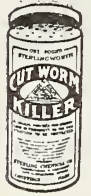

CATTLE OIL-Frotects stock from flies, qt. can 50c.

Chloride Lime.-A valuable disinfectant. Price $1 \mathrm{lb}$. box, $15 \mathrm{c}$.

Copper Solution.-To prevent blight, rot and mildew, qt. $\$ 1.50$.

Cut Worm Killer, Sterlingworth. - Non-poisonous powder. Birds and fowls that eat the dead worms are not killed. One pound protects 175 plants or a $150 \mathrm{ft}$. row. $1 \mathrm{lb}$. box, 30c.

Cyanide of Sodium.-Per 1b., $\$ 2.00$.

Fungine. - A remedy for mildew, rust and other fungus diseases, qt. $\$ 1.25$, gal. $\$ 4.00$.

GRAPE DUST - For the prevention of mildew, $5 \mathrm{lb}$. pkg. 90c.

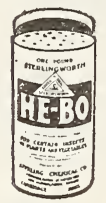

HE-BO.-A substitute for Hellebore for Currant Worms, Rose Slugs, etc., $1 / 2 \mathrm{lb}$. box $25 \mathrm{c}, 1 \mathrm{lb}$. Box 40c.

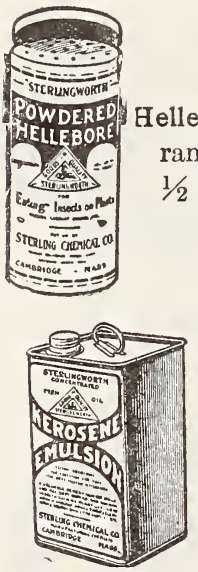

Kerosene Emulsion, Sterlingworth.-For scale and all sucking insects. Per qt. 55c, gal. $\$ 1.50$.

Lime and Sulphur Wash, Sterlingworth-The most widely used and recommended remedy for San Jose Scale. 1 gal. makes 10 to 40 gals. Prices, 1 qt. can, $45 \mathrm{c}$; gal. cans, $90 \mathrm{c.;} 5$ gals., $\$ 3.50$.

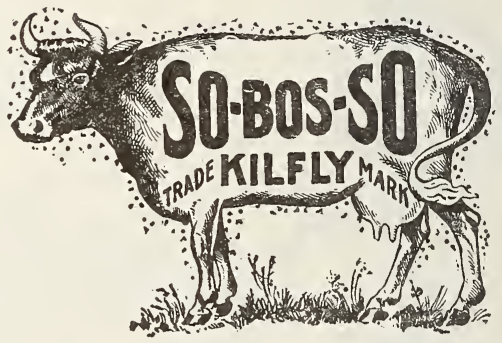

KIIFLI (So-bos-so).-An excellent preparation to protect animals from flies. Price per gal. can, $\$ 1.25$.

Lawn Compound-(Sterlingworth). A dry powder to be sprinkled over the lawn and weeds. It kills the weeds but not the grass and makes the lawn green and velvety. $5 \mathrm{lb}$. cans, $60 \mathrm{c} ; 10 \mathrm{lb}$. cans, $\$ 1.00 ; 50 \mathrm{lb}$. keg, $\$ 4.00 ; 100 \mathrm{lb}$. kegs, $\$ 7.50$.

NICO-FUME-Tobacco Paper for fumigating. Per can, $\$ 1$ and $\$ 4.50$.

NICO-FUME LIQUID-For fumigating and spray. ing. Lb. can, $\$ 1.50$. $4 \mathrm{lb}$. can, $\$ 5.50$.

NIKOTEEN-The large bottle represents the extracted product of $150 \mathrm{lbs}$. tobacco. Price, $2 \mathrm{oz}$. bottle, 40c.; arge bottle, $\$ 1.75$.

Nikoticide - A powerful tobacco insecticide for greenhouse fumigating. Cans, $\$ 1.50$ and $\$ 2.75$.

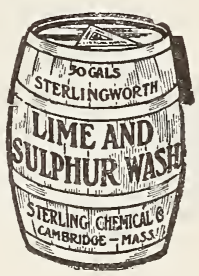

No SCAB, (Sterlingworth) - For treatment of Seed Potatoes for Scab and for grain (except loose smut of Wheat and Barley, which this preparation:will_not control). Per bottle 50c.

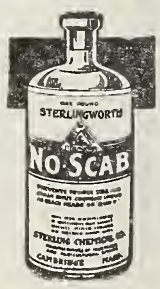




\section{INSECTICIDES (Continued)}

PARIS GREEN.-Absolutely Pure.-Put up in $1 / 4,1 / 2,1$ and 2 pound boxes. Prices according to market.

Plant Food.-Ferti-Flora, per bottle, 30c.

PLANT LICE KILLER, Sterlingworth.-For killing aphis on fruit trees, potatoes, garden truck and house plants. Pint, 30c; quart, 50c.

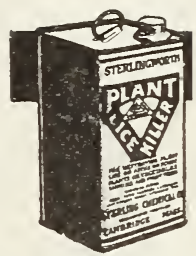

Plant Tablets.-Sterlingworth, dissolve in water, makes plants bloom luxuriantly. Price 10c.

Potash.-Per box, 20c.

PYROX.-A spray for all leaf eating insects, also a preventative of fungus diseases. Lb., 35 c; 5 lbs., $\$ 1.50 ; 10$ lbs., $\$ 2.75 ; 25$ lbs., \$6.00; 50 lbs., \$11.00; 100 lbs., \$21.00.

Rat Annihilator,-Kills and consumes the body of the rat. Pkg 20c.

Rat Corn-Kills and mummifies rats and mice, 25c and 50c.

Roach Killer.-Pkg. 25c.

Scalecide.-For spraying, especially good for San Jose Scale. 1 gal. \$1.45, 5 gals. \$5.75.

Seal Oil Soap.-A valuable insecticide for syringing and washing plants. Box 35c.

Sheep Dip.-Cooper's-In powder form pkg. makes 25 gallons. Price $75 \mathrm{c}$.

Slug Shot-Hammond's. - Destroys insects injurious to house and garden plants, potatoes, vegetables, and fruits of all kinds. Comes all ready for use. $5 \mathrm{lb}$. pkg., $50 \mathrm{c} ; 1 \mathrm{lb} ., 15 \mathrm{c}$.

Sylpho-Napthol.-A modern cleanser and purifier. Makes everything clean and healthful. One of the best disinfectants known. Price, small bottle, 25c; medium bottle, 50 c; large bottle, $\$ 1.00$; one gallon can, $\$ 3.00$; five gallon can, $\$ 12.50$; ten gallon can, $\$ 20.00$.

Sulphur, Flowers of.-Much finer and preferable to Flour of Sulphur, for the prevention and cure of Mildew on grapevines, roses, etc. Price per lb., 12c; 100 lbs., $\$ 9.00$.

Sulphuric Acid.-Per bottle, \$1.25

Tobacco Dust.-A very fine dry powdered tobacco. Price per lb. 15c.

Tobacco Stems.-For fumigating. In bales of about $100 \mathrm{lbs}$. each, 3c per lb.

TREE TANGLEFOOT. - A sticky substance applied directly to the bark to protect trees against climbing insects. $1 \mathrm{lb}$. can, $50 \mathrm{c} ; 3 \mathrm{lb}$. can, $\$ 1.45 ; 10 \mathrm{lb}$. can, $\$ 4.50 ; 20 \mathrm{lb}$. can, $\$ 8.75$.

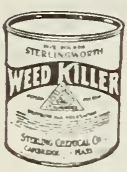

Weed Killer, Sterlingworth.-A powder, dissolves in water, for use on walks, drives and gutters. $1 \mathrm{lb}$. pkg., makes 15 gals., $60 \mathrm{c} ; 5 \mathrm{lb}$. pkg., $\$ 2.25$.

Weed Killer, Pino Lyptol.-Per 5 gal. keg, $\$ 7.00$.

XL ALL.-Liquid insecticide, for spraying and sponging to destroy insects, quart can, $\$ 1.85$; half gal. can, $\$ 3.00$; one gal. can, $\$ 5.25$.

XL ALL. - Vaporizing Compound for fumigating, per bottle, sufficient for fumigating 40000 cubic feet, $\$ 8.00$.

Lamp for Fumigating.-Complete with stand, \$1.75.

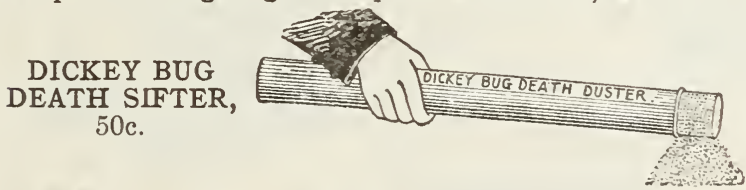

WHALE OII SOAP.-Per 1b., 25c.

WHALE OIL SOAP, with Tobacco.Sterlingworth - Makes an

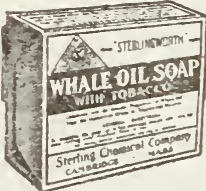
excellent wash for trees and plants, and for smearing on the trunks of trees, to prevent worms from crawling up. Excellent for destroying the Green Worm on Cabbages. $1 \mathrm{lb}$. box, 35c.

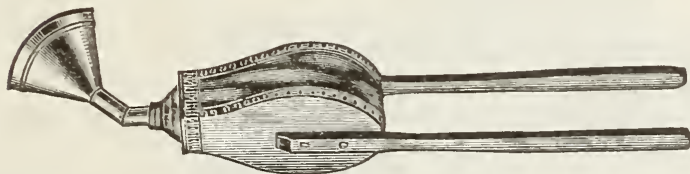

"DANDY IION" WEED

BELLOWS OR GUN.-For applying dry, Paris Green, Hellebore.

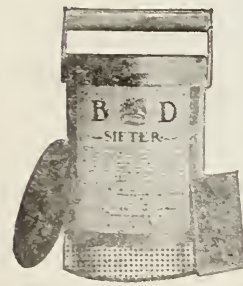
Tobacco Dust, Sulphur, etc., $\$ 1.75$.

INSECT POWDER GUN.Small, 20c.

ACRE AN HOUR SIFTER

For using Bug Death and other Insecticides dry. It is well named. Price, $\$ 5 \mathrm{c}$.

TORCHES, Made of asbestos, $40 \mathrm{c}$.

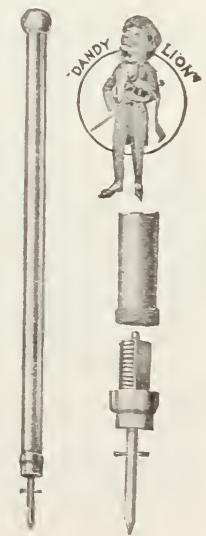


FRANK HOWARD, PITTSFIELD, MASS.

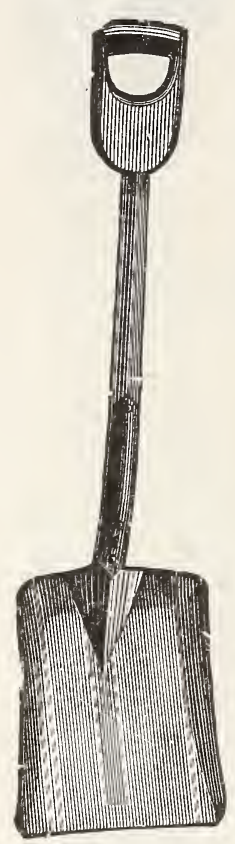

\section{SHOVELS}

Long Handle D Handle Long Handle D Handle Subject to change in market.

Ames, $\quad \$ 1.85$

Blair,

1.60

Round

Square

Square

Lee,

Brown,

1.60

1.35

STEEL SCOOPS

1.60
1.60
1.35
COOPS

$\begin{array}{rr}\$ 1.85 & \$ 1.85 \\ 1.60 & 1.60 \\ 1.60 & 1.60 \\ 1.35 & 1.35\end{array}$

Polished

Polished

SANDERSON'S No. 2, - - - - - $\$ 1.65$

\begin{tabular}{|c|c|c|c|c|c|c|}
\hline & No. 3, & - & & & & \\
\hline 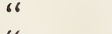 & No. 4, & - & - & & & \\
\hline & No. 5, & - & - & & & \\
\hline & No. 6, & - & - & & - & \\
\hline & No. 7, & - & - & - & & \\
\hline
\end{tabular}

Ex-Strapped

CONNEAUT,-Popular with the Coal men. $\$ 1.50$

$\$ 2.20$

2.50

STEEL FURNACE SCOOP, \$1.25

WIRE POTATO SCOOP, $\$ 2.65$

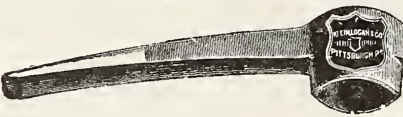

PICKS-Adze

Eye Railroad

$\$ 1.15$

\section{SPADES}

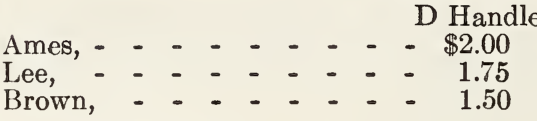

Long Handle

$\$ 1.35$

\section{HANDLES}

Sledge.

$20,25,30$

Hammer...........15 and $20 \mathrm{c}$

Hatchet................. .25

Pat Cross Cut Saw, per pr 40,50

Ice Hook. ..........50 to $\$ 1.00$

Axe-See Axes

Long or D Shovel............. 50 to 50

Manure Fork.......... to .50

D. Spading Fork............50

Long Spading Fork...., 40 to 45

Hay Fork.................40

Hoe and Rake..........30 and .35

\section{BRICK TROWELS}

Disston's ...... \$1.25, 1.50, 1.75 Pointing $41 / 2$ inch............ 35 " 5 inch............45

MASON'S Hocks .............

"Floats or "Darbies" 85

Tape Lines $50 \mathrm{ft}$ "....... 1.15

" $\quad 75 \mathrm{ft} . \ldots \ldots 75$ to 4.75

، $100 \mathrm{ft} . \ldots 1.00$ to 9.00

\section{PLASTERING TROWELS.}

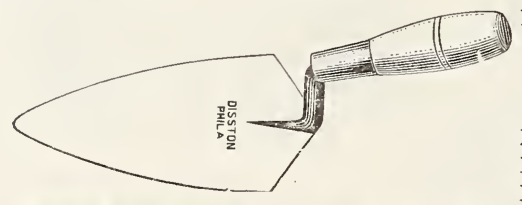

Disston's $101 / 2$ inch. . 1.65 “ $\quad 11$ inch 1.35 and

* $111 / 2$ inch 1.85

Mason's Sand Screens.

Medium.......\$6.50

Large..........7.50
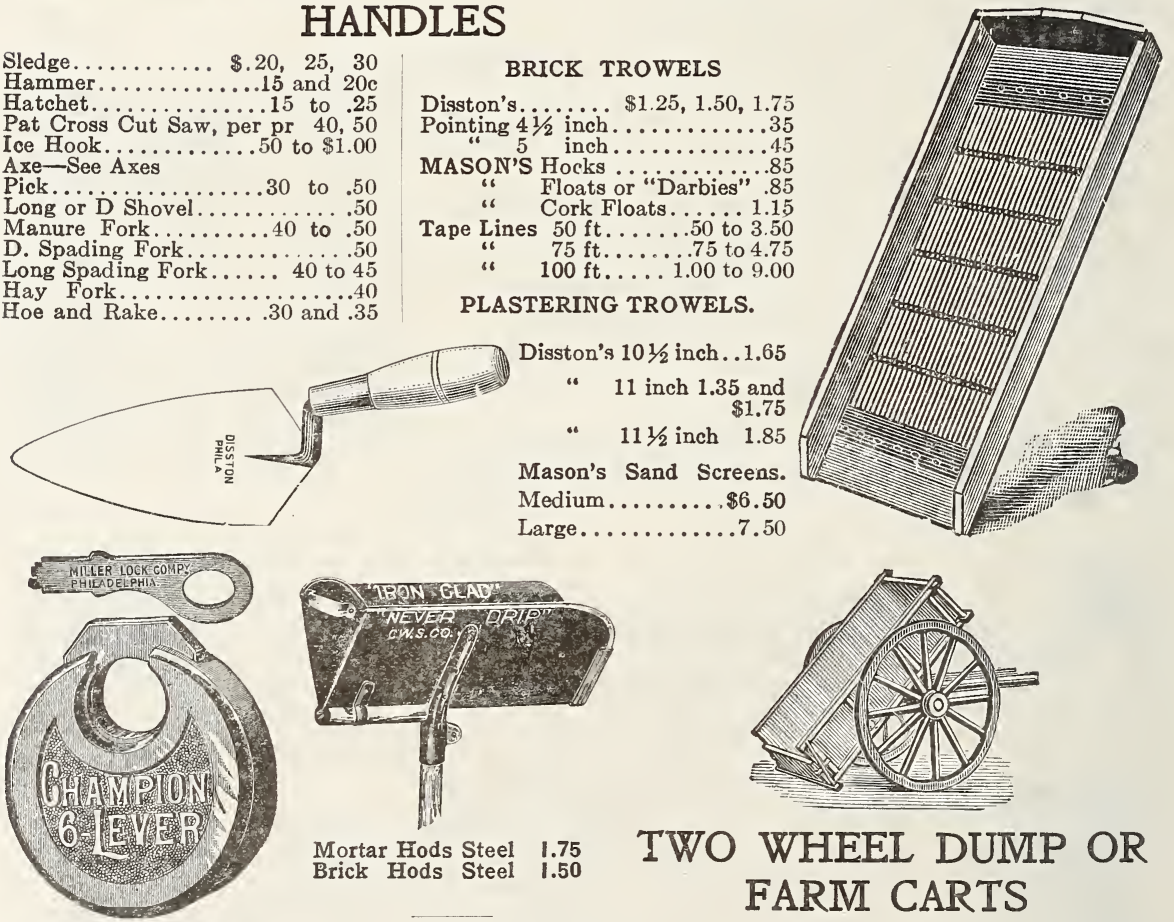

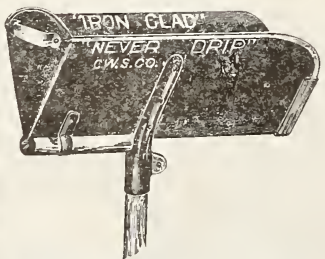

Mortar Fiods Steel 1.75 Brick Hods Steel 1.50

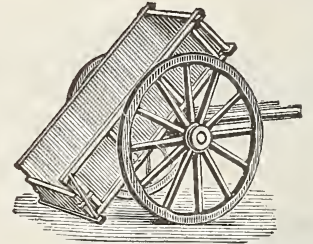

TWO WHEEL DUIMP OR FARIM CARTS

\section{PADLOCKS}

$25 \mathrm{c}$ to $\$ 2.50$. Specia Milk Can Locks, $75 \mathrm{c}, 1.00,1.25$
Dimensions of Body

Medium, $5 \frac{1}{2} \mathrm{ft}$. $\times 3 \frac{1}{2} \mathrm{ft}$. 12 in. $1 \frac{3}{4}$ in. steel 4 inch

List Prices

85.00

100.00

10.50 


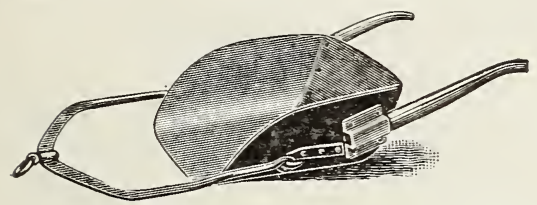

\section{SOLID·STEEL SCRAPER}

No. 0 Extra Large, Two Horse, Capacity 9 Cubic feet with Runners, - - - - $\$ 22.00$

No. 1 Large

No. 2 Medium

No. 3 One-horse

\section{NO. 75-A WHEELBARROW}

No. 75A.-A perfect end dump contractor's barrow,

capacity 4 cubic feet, - _ _ _ _ $\$ 8.50$

All Steel Wheelbarrow; _ _ _ _ _ _ $\$ 11.00$

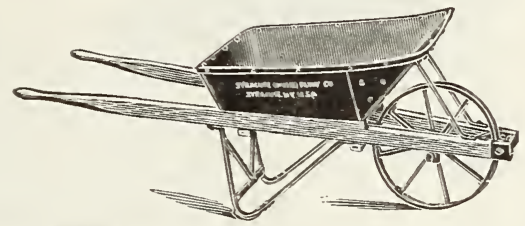

\section{STEEL TRAY WHEELBARROW}

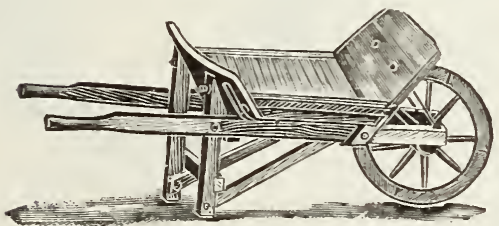

No. 2 Capacity 3 cubic feet, with steel wheel

$\$ 5.75$

No. 4 "Steel Wheel Barrows-from $\$ 9.00$ up.

625

Special prices on quantities

BOLTED RAILROAD or CANAL BARROW, patent wood wheel.

BOLTED RAILROAD or CANAL BARROW, patent steel wheel.

\section{WINDOW COAL SHUTE}

Hopper Opening. Outside Rim. Size "A" 22 wide-16 high $25 \times 19$
Size "G" 32 “ 24 " $35 \times 27$

\section{MEASURING RODS}

$6 \mathrm{ft}$. long, with brass tips, graduated to $1 / 8$ inch $10 \mathrm{ft}$. long, " $10 \mathrm{ft}$. long,

\section{CART HARNESS}

NEW ENGLAND PATTERN, (collar not included). Prices on application.

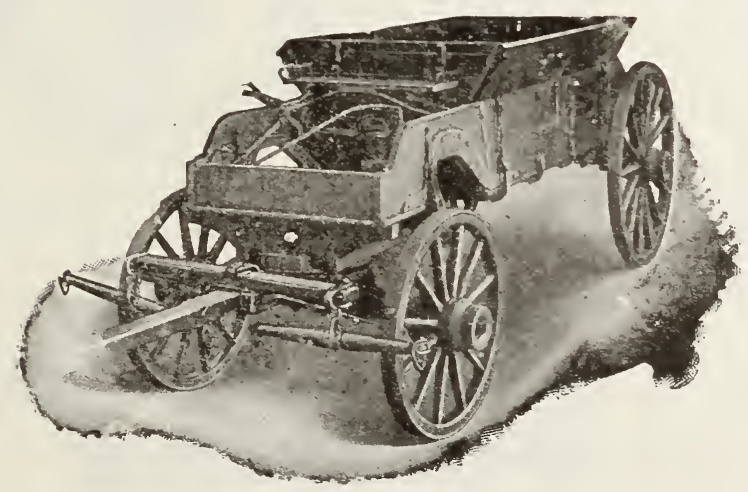

\section{WATSON DUIVIPING WAGON}

The Best Bottom Dumping Wagon built.

$11 / 2$ yard capacity, 3 inch Tire, Bottom lined, Flaring Side-boards.

2 yard capacity, 4 inch Tire, Full lined, Flaring Side-boards.

Prices on application 


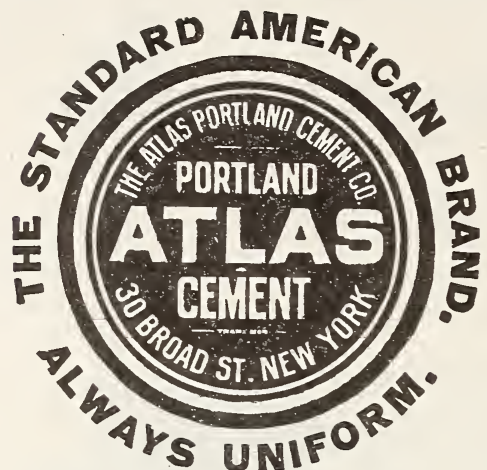

\section{PORTLAND CEMENT} (Best Brands Only.)

We are in a position to furnish Portland Cement in any quantities from a pound to any number of carloads, our facilities for supplying on large contracts being especially good. We will figure on board cars, at our storehouse, or delivered on the job as desired. Prices on application.

KEENE CEMENT-For fine plastering and tile work, per bag $\$ 2.50$.

\section{LIME}

We are Sole Agents in this vicinity for the celebrated Farnum Cheshire Lime, and carry in stock the following brands:

Black Label Lump. For Brick and Stone Work.

Finishing Lime. (Hand picked) for Finishing Coat work.

Red Label Lump. Selected I umps for whitewashing.

\section{WALL PLASTER}

PEERLESS NEAT. To be used with sand, a splendid Plaster, works easy under the trowel, dries quickly, economical and is very much liked by the masons and builders. 100 lb. bag, $\$ 1.45$, per ton including bags, $\$ 26.00$.

PEERLESS WOOD FIBRE. Ready to use. Works nicely under the trowel, makes an excellent wall. $100 \mathrm{lb}$. bag, $\$ 1.45$ per ton including bags, $\$ 26.00$.

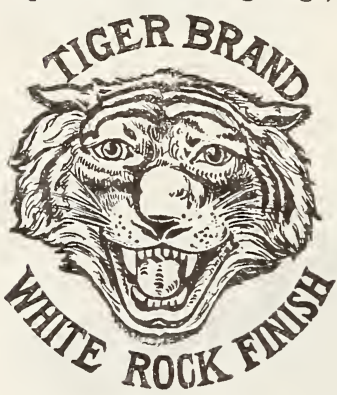

HYDRATED LIME. "Tiger Brand." "White Rock Finish." We recommend this always for

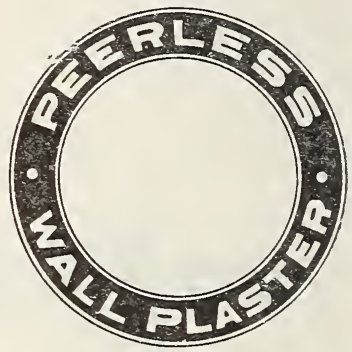
finish work. For plastering and Finishing Coat work. Per $50 \mathrm{lb}$. bag, 65c; per ton, $\$ 24.00$.

MASONS CALCINED PLASTER (Plaster of Paris), Higginson's probably the best; per $\frac{1}{2}$ bbl. $\$ 2.25$; per bbl. $\$ 3.50$.

HAIR FOR PLASTERING. Extra long goat, per bushel sack $60 \mathrm{c}$.

MORTAR RED. Dry per lb. 3c, special prices in quantities.

ATLAS WHITE PORTLAND CEMENT a pure white Portland cement, per bag $\$ 1.50$. Special price in quantities.

PLASTER BOARD "PEERLESS", a very strong plaster board, 32 in. $x 36$ in. Price per board $24 \mathrm{c}$

CONCRETE HARDENER,-(Master Builders.) For waterproofing and surface hardening of concrete, per bag of 50 lbs. $15 \mathrm{c}$ per $1 \mathrm{~b}$.

Concrete Hardener (Metalcrete.) Bag of 50 lbs., 15c lb.

MEDUSA WATERPROOF COMPOUND, per bag, $40 \mathrm{lbs}$, $15 \mathrm{c}$ lb. Special price in quantities.

MEDUSA WATERPROOF PASTE, One gallon to one bbl. cement, dissolve in the water, 1 gal. can $\$ 1.15,5$ gal. can, $\$ 5.50$

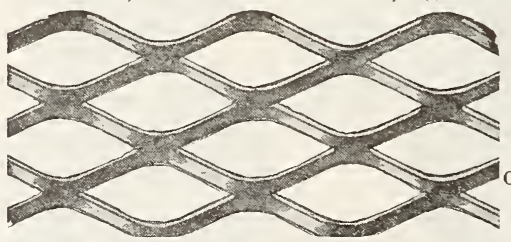

METAL LATH

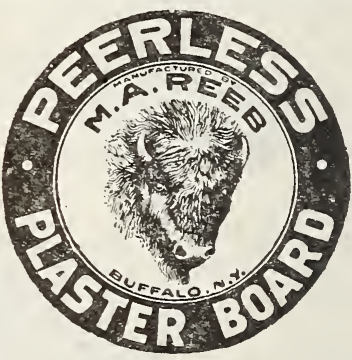

BERGER STANDARD, 24 Gauge, in bundles of 9 sheets or $142 / 3$ yards; per sq. yard. Prices on application.

MAHONING, 24 Gauge, 21 yards in a bundle of 14 sheets; per square yard, Prices on application.

CORNER BEAD, in 8,9 and $10 \mathrm{ft}$. length, with clips, per ft. Prices on application.

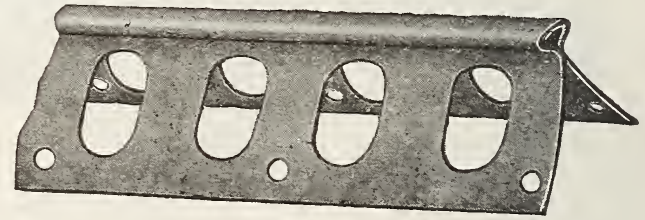


STORM KING ROOFING.-A splendid roofing, it will certainly please you, the price is extremely low considering the quality.

1 ply, per roll of $10 \mathrm{~s}$ sq ft.,

$\$ 2.25$

2 " "

2.75

3 “ "

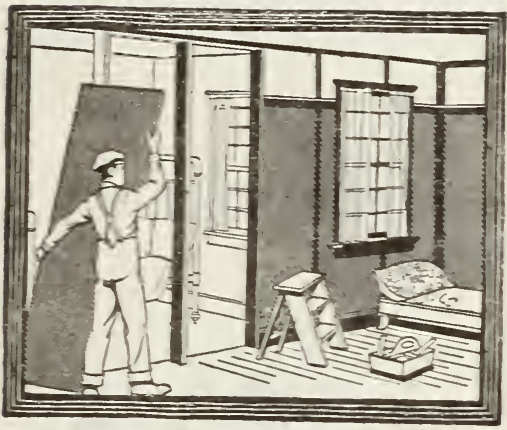

\section{WA I L BOARDS}

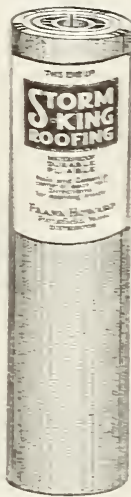

NEPONSET WALL BOARDS.-For walls and ceilings, both surfaces raterproofed, made in three finishes-Oak, Cresm Thite, 32 inches wide, per 1,000 sq. ft.,

\section{BLACK WATERPROOF BUILDING PAPER.}

-In rolls of 250 and 500 square ft. Price per 100 sq. ft.,

RED ROPE ROOFING. - An excellent low cost roofing, will last for sereral years, Price per square of $10 \mathrm{st}$.,

$\$ 2.25$

TARRED PAPER.-Single ply, per roll of 320 square feet (about $40 \mathrm{lbs}$ ). jc lb. Two ply, per roll of 10 square feet, $\$ 1.50$. Three ply, per roll of $10 s$ square feet. $\$ 2.00$

AMATITE ROOFING.-An excellent roofing material, made of several layers of $\pi$ ater. proof material and pitch, with a layer of gravel on one side. Per roll of $10 \mathrm{~s}$ sq. $\mathrm{ft}$ $\$ 3.00$. Special prices on large quantities.

EVERJET ROOFING PAINT.-(Black)-For outside or inside use on metal or rood Prevents rust, protects from reather, lasting. One gallon can $\$ 1.00$.

ELASTIGUM - A tough adhesire plaster cement for roofs, can $25 \mathrm{c}$

ROOF COATING-For tarred ready roofing, per gal can $\$ 1.00$.

\section{THE REYNOLDS ASPHALT SHINGLES}

Fire resisting, lighter than Slate, as cheap as $\Pi$ rood Shingles and will last very much longer. Made in Red, Grey, Green and Pioneer Rock. Some cities in Massachusetts forbid the use of rood shingles, a lotrer rate insurance is charged in some places where asphalt shingles are used. Be sure you get the Reynolds, it is the best.

Price, Red or Green per 1000 ,

" Grey " " " "

$$
\begin{array}{r}
5.25 \\
7.25 \\
7.00
\end{array}
$$

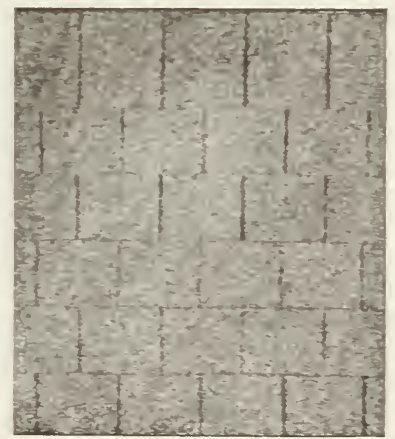

ROLL ROOFING.-For valleys to match the shingles.

Per roll, $\$ 3.65$.

ROOFING CEMENT "MATEX".-In 25 and $50 \mathrm{lb}$. pails $1.5 \mathrm{c}$.

ROOFING CEMENT "RUTLAND",-In $10 \mathrm{lb}$. cans, \$1.7. per can.

It also makes an excellent roof

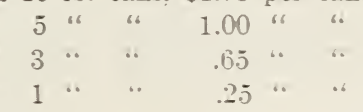




\section{THE ADRIANCE BUCKEYE MOWER}

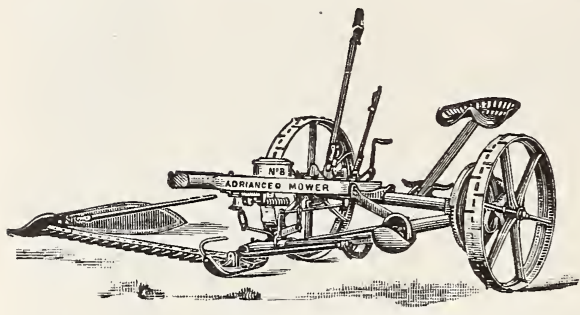

The Adriance Buckeye Mowers have long been considered Standard Goods and to-day are as good as are made. They are made both in the Buckeye Gear and Chain Gear.

THE BUCKEYE GEAR IS USUALLY PREFERRED.

One-Horse, $3 \mathrm{ft} .6$ in. or $4 \mathrm{ft}$. Either chain or Standard - - - - - - - $\$ 80.00$ Two-Horse $4 \mathrm{ft}$. 6 in. $5 \mathrm{ft}$.

" " " " "

McCORIMICK MOWING MACHINE

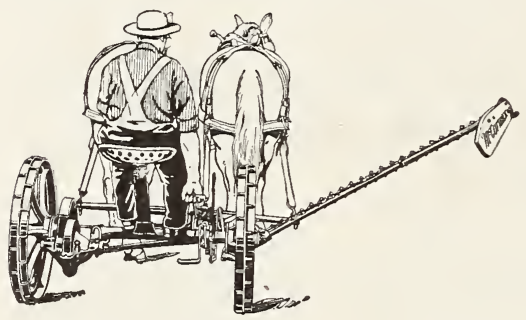

The McCormick Mower is one of the very reliable machines which we carry. It is light running, yet a strong, substantial Mower. Price One Horse, $4 \mathrm{ft}$. cut, $\$ 80.00$ Price Two Horse $5 \mathrm{ft}$. cut, 85.00

\section{WALTER A. WOOD MOWING MACHINE}

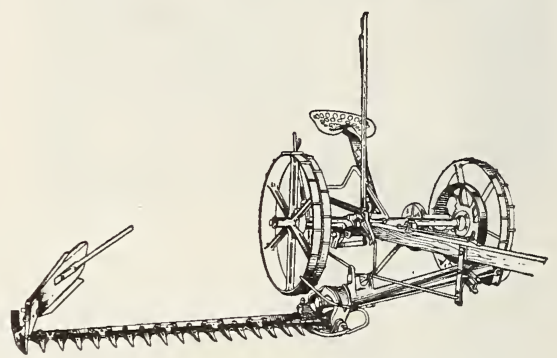

The Wood Machines are well and favorably known the world over.

The New Vertical Lift is proving very popular. Price, $5 \mathrm{ft}$.,

\section{WOOD STEEL HAY TEDDER}

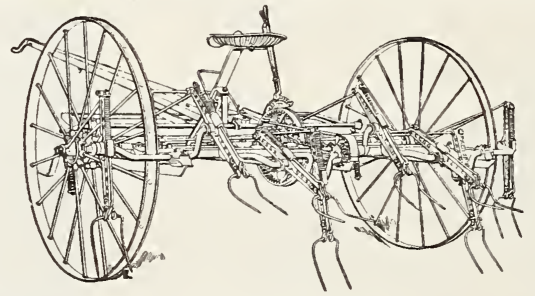

Built of Steel throughout, has six forks, is strong and durable, adjustable for one or two horses.

PRICE,

The Flying Dutchman Side Delivery Rake. This can be used in connection with the Hay Loader or in an entirely separate manner. It is however more often used with the Hay Loader and in this way hay can be raked, loaded and transferred from the field to the barn very rapidly. Price _ _ _ _ _ _ 


\section{THE McCORMICK RAKE}

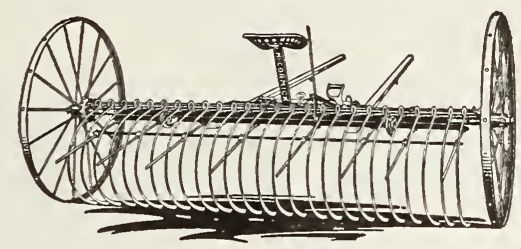

An excellent Self-Dump Steel Rake 8 feet wide-has 25 teeth also two guard teeth; easily operated, strong and durable.

Price $\$ 46.00$

\section{THE YANKEE HORSE RAKE}

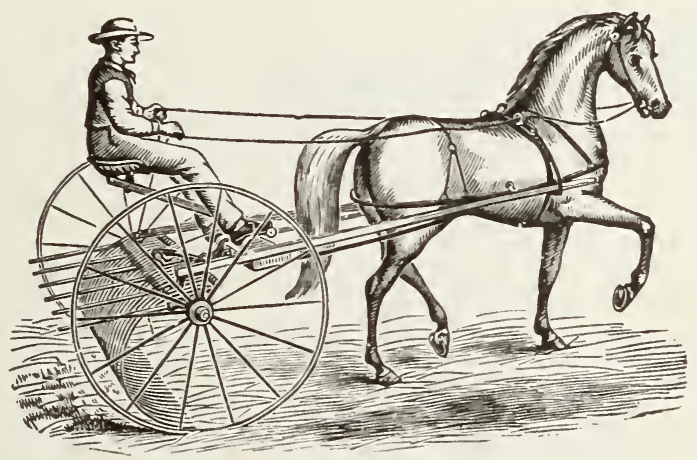

A very well known and thoroughly reliable rake, very easy to operate.

Very much liked in the Berkshire Hills.

Price $\$ 42.50$

REPAIRS FOR FARM MACHINERY-We make a specialty of supplying parts for farm machinery. Bring old part or number of the piece wanted.

\section{THE ADRIANCE CORN BINDER}

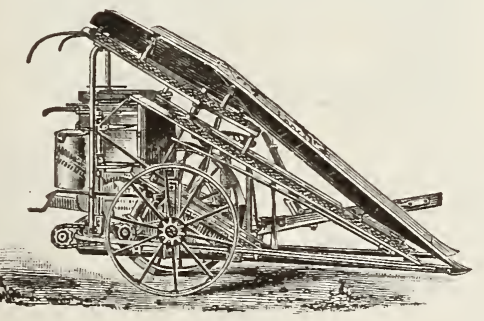

This is a splendid working, strong and substantial machine, and backed up by the wellknown Adriance Buckeye people. Contrary to a general claim by some other manufacturers, this is one of the lightest draft corn binders made. Let us show you this machine. We guarantee it. 


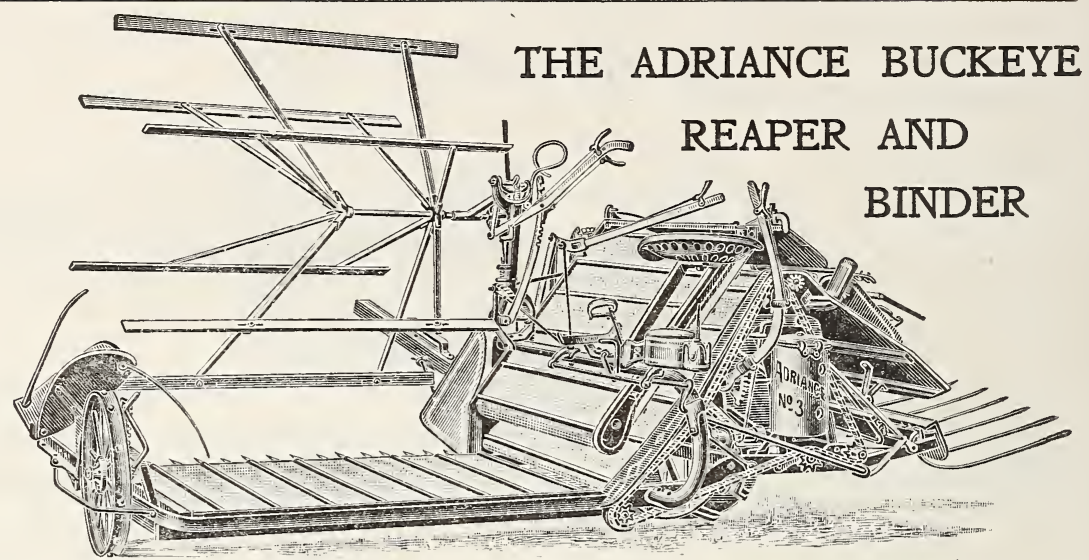

Onel of the best on the market, strong, light draft, and a perfect worker. Special Binder Catalog on Application.

Price $\$ 235.00$

\section{THE FLYING DUTCHIMAN HAY LOADER}

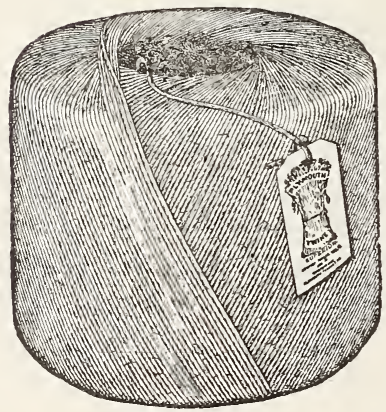

Loads from swath or windrow-a great labor saver and probably one of the best loaders made. Price, $\$ 125.00$.

HAY CAPS-Canvas. Prices given on application.

\section{BINDER TWINE}

Our Binder Twine is smooth, even, more feet to the pound than many other makes. It is Plymouth Twine, none better-in balls of $5 \mathrm{lbs}$. each-10 balls to the bale. Prices according to market. 


\section{HAND HAY AND LAWN RAKES}

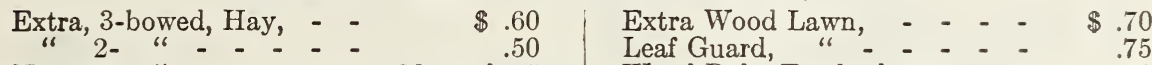

No. 1,2- " - - - - 30c and .45 Wood Rake Teeth, doz., - - - $\quad .10$

WIRE LAWN RAKE,-Reversible, 85c.

SCYTHE SNATHS

Ash, Grass, - - - - - - $\$ 1.50$ Ash Bush, - - - - - $\$ 1.75$

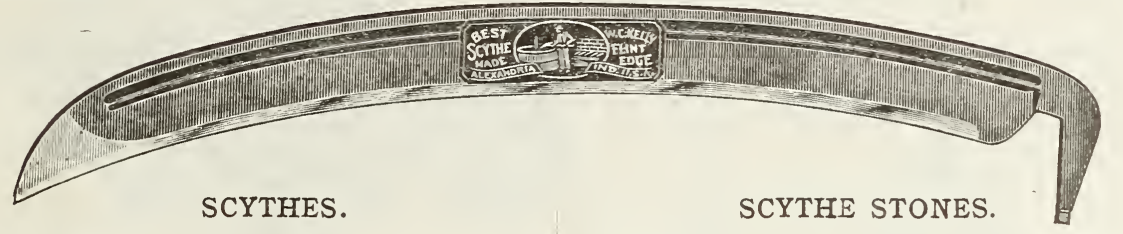

Solid Steel, - - - - - - $\quad 1.75$

Our Special Solid Steel, - - - $\quad 2.00$

Bush, - - - - - - - 1.50

Bramble, - - - - - - - 1.50

Grain Cradle, - - - - - 2.75

Snath Wrenches, - - - - - .05

.05

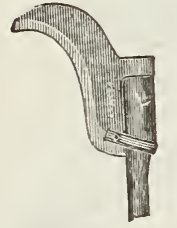

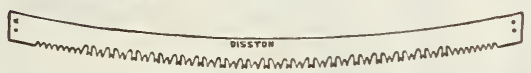

DISSTON

English Round, - - - - -

Emery Round or Cigar, - - - $\quad .10$

Carborundum, - - - - - $\quad .25$

Emery Rifles, - - - - . . 10

Carborundum Rifle, - - - - $\quad .25$

Red End (coarse), - - - - - $\quad .10$

White Mountain, - - - - - $\quad .15$

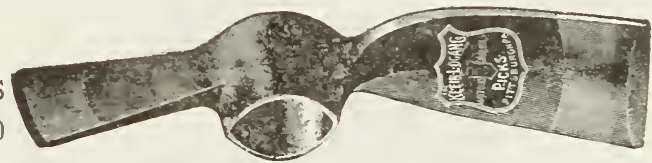

Axe Mattocks, - - - - - $\$ 1.40$

Pick Mattocks, - - - - - 1.40

Mattock, or bog hoe, - - - 1.25

Saw Sets, - - $\$ 1.25$ and 1.50

Ice Saws, $4 \mathrm{ft}$. $\$ 5.25$, - $\quad 4 \frac{1}{2} \mathrm{ft}$., 5.50

Cross Cut-Narrow, including handles, $5 \mathrm{ft} . \$ 3.00$

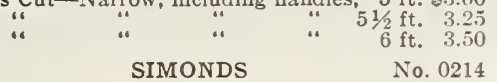

Cross Cut-Narrow, including handles, $5 \mathrm{ft} . \$ 3.25$

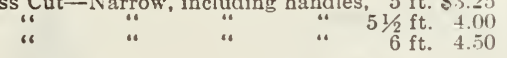

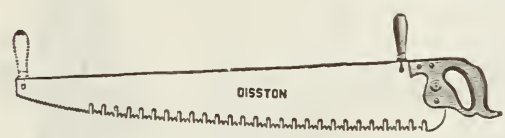

DISSTON

Cross Cut one man $31 / 2 \mathrm{ft}$.

$$
\text { "“ } \quad \text { " } 4 \quad 4 \text { ft., }
$$

Buck Saw-Either narrow or wide blade,

$\$ 1.50 \$ 2.00$ and $\$ 2.50$ “ Blade only, $\$ 1.50 \$ 1.10$ and 1.25

“ Frame only, without Strainer, $50 \mathrm{c}$

“ Strainers, without Strainer, $15 \mathrm{c}$ and $20 \mathrm{c}$

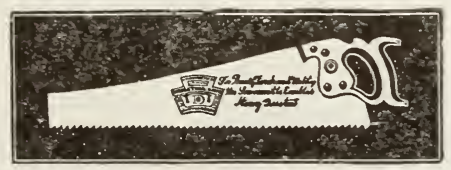

Carpenters' "Cut Off" Disston's 20,24 and 26 in. in two grades, $\$ 2.00$ to $\$ 3.85$ Carpenters" "Cut Off" Simonds $\$ 2.00$ to $\$ 3.85$ Carpenters' "Cut Off" Simonds $\$ 2.00$ to $\$ 3.85$

$\$ 1.25$
$\$ 2.00$

Keyhole Extension,

Saw Clamp (Swivel),

\section{GRAFTING WAX.} Trowbridge, $1 / 4 \mathrm{lb}$. stick, $\quad-\quad-\quad-\quad 20 \mathrm{c}$ $1 \mathrm{lb}$. stick, - - - $60 \mathrm{c}$

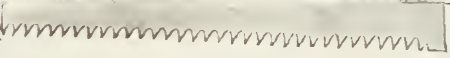

Cart Ice Saws, - - - - - 2.75 MEAT SAWS.

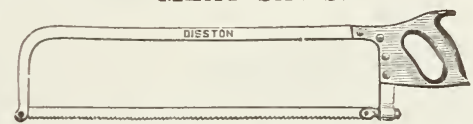

Family Size, 75c, 18 in. Disston's, $\$ 2.00$ 20in.Disston's, \$2.25, 22in. Disston's, 2.50 AXES.

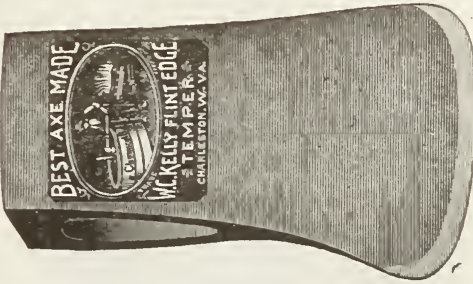

Our Best, - - - - - - - - - - - $\$ 2.00$ Connecticut pattern, - - - - - - 1.75 Axes, Handled, - - - - $\$ 2.00$ and 2.25 " " Boys, - - - - - - 1.50 Axe Stones, - - - - - - - $-\overline{-}-\bar{c}$ - $50 \mathrm{c}$ to $50 \mathrm{c}$ Axe Wedges, - - - - - - - - 5c GRAIN CRADLES.

Turkey Wing, 4 fingers, $--_{-}-{ }_{-} \$ 6.50$ Turkey Wing, 4 fngers, _ _ - - $35 \mathrm{c}$ each

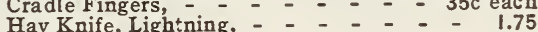

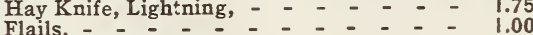
Carpenters' Squares, Saw Bucks, Folding, - - - - $50 \mathrm{c}$ and $90 \mathrm{c}$ 


\section{CLOVER LEAF STEEL TRACK HAY CARRIER}

An up-to-date, practical Swivel and Reversible Carrier. Simple in construction. Anyone can put them up.

Clover Leaf Car, - - - $\$ 12.00$

Double Steel Track, per ft., $\quad .30$

Steel Track Hanger, per doz., $\quad 2.40$

Brackets, per doz., - - - 1.00

Floor Hooks, each, - - $\quad .25$

Pulleys, Knot Passing, each, .75, .90

" Wood Sheave, each, .75, .90

"Iron, each, - - - .50

Drive Screws, per gross, - 1.50

Louden Junior Hay Carrier

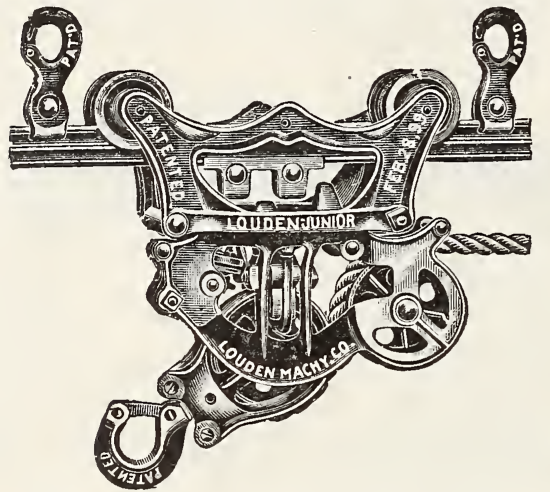

One of the best Hay Carriers, operates in any kind of barn - it is Swivel and Reversible.

Price Louden Junior Car, - - - $\$ 12.75$

" " Senior " - - - 13.50

“ " Double Bead Track, ft., .30

" Standard Hangers, doz., - - 2.40

" Screw Eyes. each, - - - $\quad .20$

" Hoisting Whiffletree, each, - 2.25

"Bracket Pulley Holder, $\quad 1.00$

ROPE

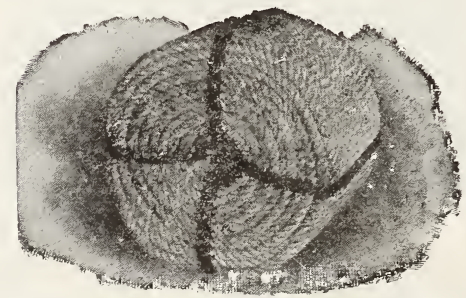

We carry in stock pure Manila Rope, sizes from $1 / 4$ inch to 1 inch; prices according to market.

\section{Hay Bale Tíes}

Stock sizes: $7 \mathrm{ft} .3$ in. and $9 \mathrm{ft}$. Prices variable.
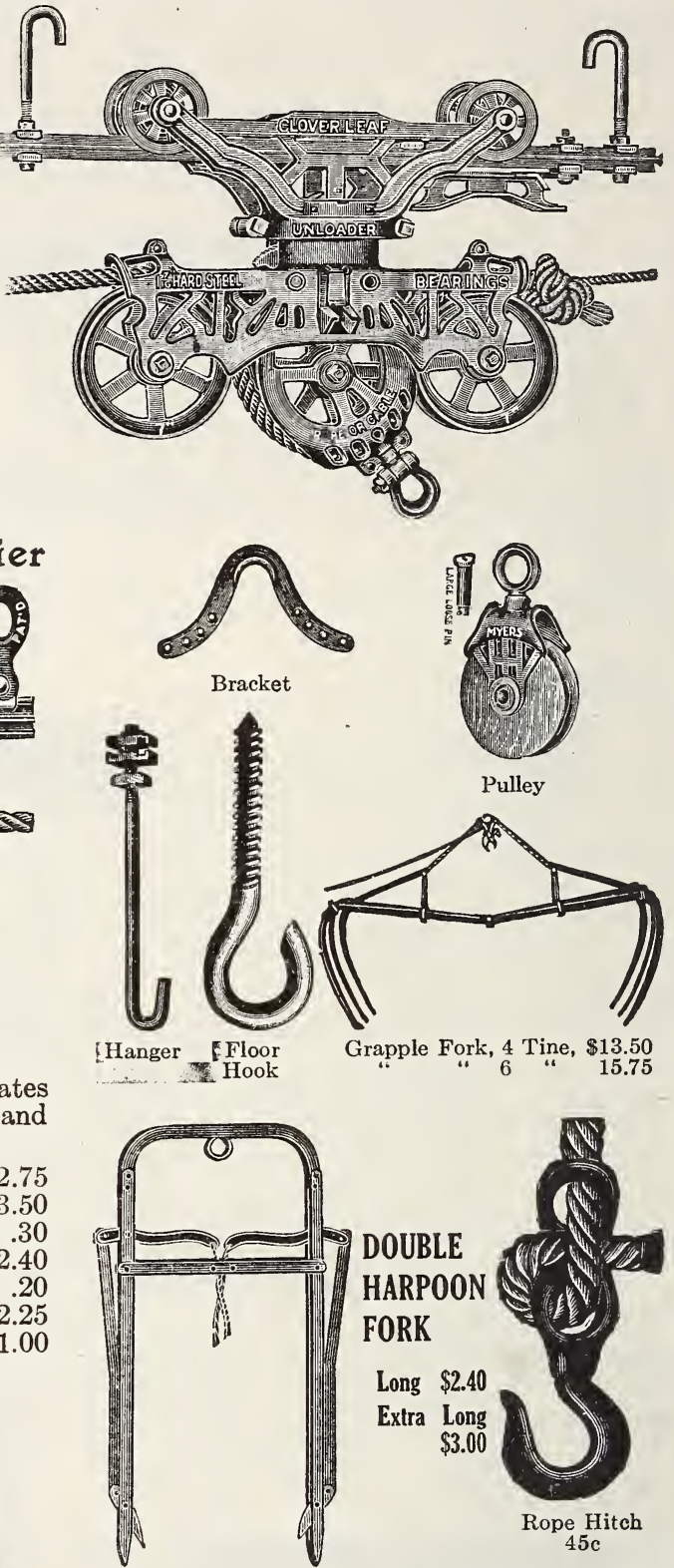

DOUBLE HARPOON FORK

Long $\$ 2.40$

Extra Long $\$ 3.00$
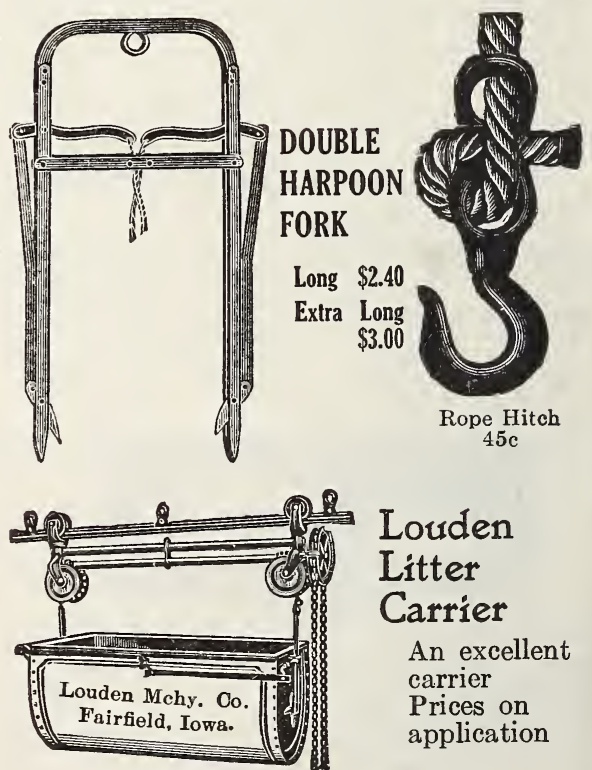

Louden Litter Carrier

An excellent carrier Prices on application 


\section{MOWING MACHINE KNIVES, SECTIONS GUARDS AND REPAIRS}

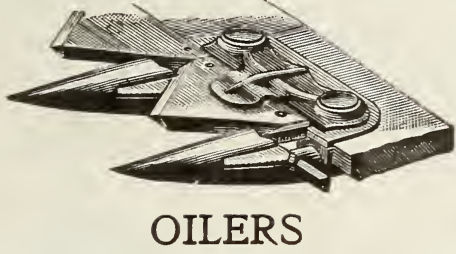

No. 1. Zinc Oiler (Burkeye) ......15c No. 2. " " (tall) ......... " Newing Machine Oiler ....... ${ }^{30} \mathrm{c}$ and $15 \mathrm{c}$ Steel and Copper............20 to $75 \mathrm{c}$

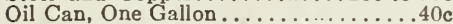
Oil Can, Five Gallon $\$ 1.00, \$ 1.50$ and 1.75

FAUCETS

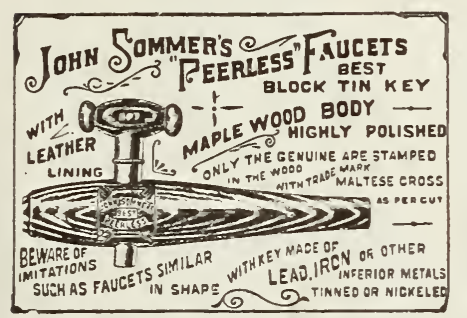

\section{STILSON WRENCHES}

$\begin{array}{lr}6 \text { in. } & \$ 1.25 \\ 8 \text { in. } & 1.50 \\ 10 \text { in. } & 1.75 \\ 14 \text { in. } & 2.25 \\ 18 \text { in. } & 3.00 \\ 24 \text { in. } & 3.70 \\ 36 \text { in. } & 6.70 \\ 45 \text { in. } & \end{array}$

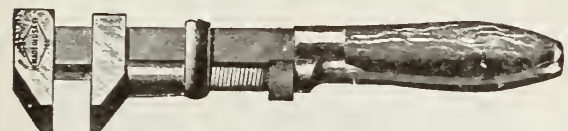
o. 2. Metal Key
The furnishing of these goods is an important partcof our business. We are in a position to supply you with PARTS of any Mowing Machine Rake, Tedder, Plow, Harrow, or most any Agricultural Implement made; and it is always best if possible to bring or send the old parts to insure a fit. It is important that vou use the Best Knives and Sections.

We sell only the Best Sections. Wepositively refuse to handleacheap section. The best are worth the money. the others are worth nothing.

No. I. Metal Key Every one is

Somers'Best......60c Warranted

Somer's Best......75c

Ivy Wood 6 inch ....20.20

" 7 "

" 8 " .....30c

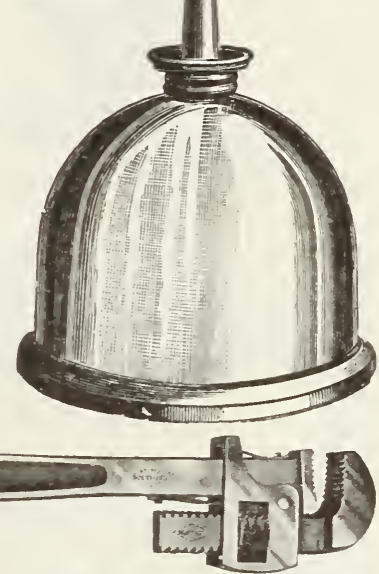

SCREW DRIVERS

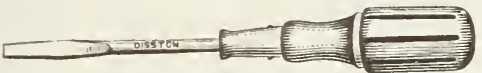

PRICE, 25c TO $\$ 2.00$

Nail Hammers steel, $65 \mathrm{c}$ and $\$ 1.00$ "“ " Maydole, $75 \mathrm{c}, \$ 1.00 .1 .25$ Riveting “" $\$ 1.20$ and $\$ 1.25$ Tack " $10 \mathrm{c}$ and $25 \mathrm{c}$ Cold Chisels, each "(heavy) each $25 c^{\circ}$ to $50 \mathrm{c}$ Rivet Punches, $20 \mathrm{c}$ and $25 \mathrm{c}$

\section{Our Standard Vise}

Not a cheap one, but a strong, wellmade vise

No. 63 and 64 - $\quad$ - $\$ 2.50$

“66 - - - 3.80

" $67-$ - 67.75

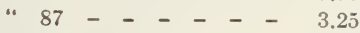

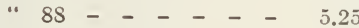

“ 89 -

“9 90 - 9 - 7.00

“91 - 91 - 8.50

The Handy Worker

A Very Handy Tool for any Shop combines sever a 1 hand working tools, Vis e, Pipe Vise, Anvil Cutting $\mathrm{H}$ ardie, Drill Press, a nd Grinding Wheel.

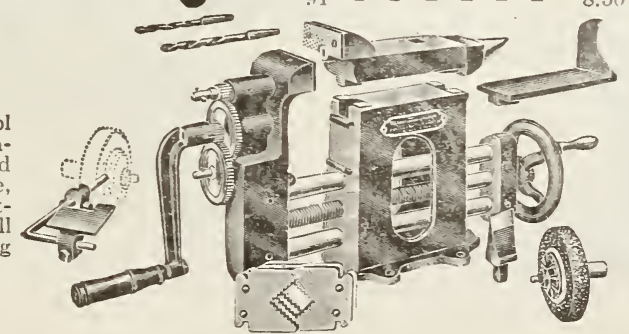




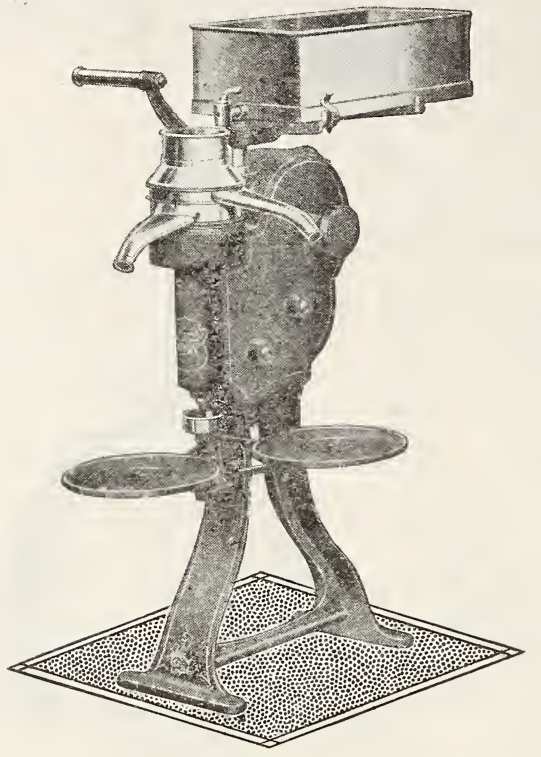

\section{THE NEW UNITED STATES SEPARATOR}

With new self-balancing disc bowl, Speed Indicator Bell, low crank speed (42 turns of crank to the minute) seems to be the last word in separators.

No. 30 Guar. Cap. 200 lbs. $\$ 60.00$

\section{Special \\ Electric Motor Alternating}

No. 29 " " 300 “ 70.00

No. 28 “ “ 350 “ $\quad 82.50 \quad \$ 50.00$

No. 27 “ “ 500 “ $92.50 \quad 50.00$

No. 25 “ “ 750 “ $111.00 \quad 55.00$

No. 24 “ “ 1,000 “ $130.00 \quad 55.00$

No. 22 " “ 1,350 “ $175.00 \quad 55.00$

\section{CHAIN HANGING CATTLE STANCHIONS}

The best and easiest method for fastening cattle in the stable.

PRICE, Wood - - - - - $\$ 1.60$

"Steel - - - - - - $\$ 3.80$

“ Heavy Bull - - - $\$ 3.50$

Chain Cattle Ties.
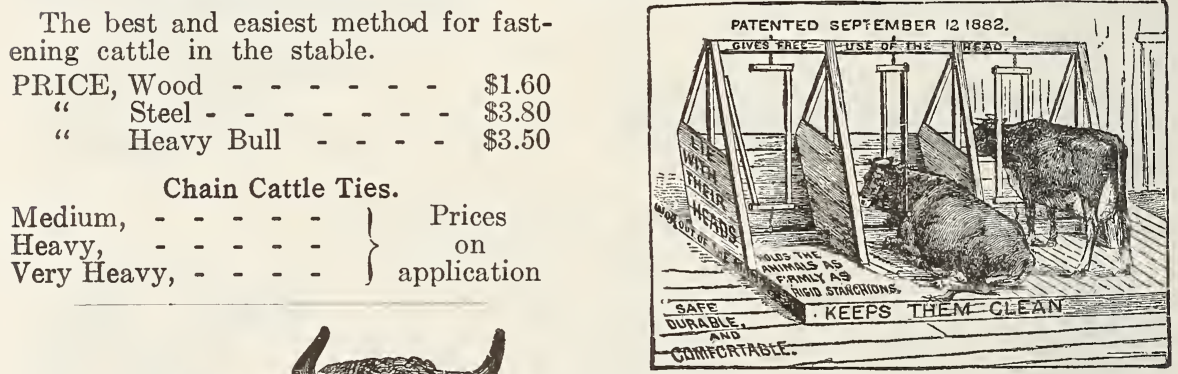

DANA'S STOCK LABELS

An easy and practical way of marking Stock. Cattle labels may be marked with owner's name not exceeding 13 letters, and post office address, not exceeding 13 letters. Sheep label size has room for only 10 letters, Per doz. Per hun. Cattle labels lettered and numbered, $\quad .75 \quad \$ 4.00$ Sheep and hog labels lettered and num-

bered, PUNCHES.-Cattle label size, " Each $\$ 1.50$ Sheep

1.00

The New Sharples' Suction-Feed Tubular Separator

No.

$1 \mathrm{~s}$

$2 \mathrm{~s}$

$3 \mathrm{~s}$

$4 \mathrm{~s}$

$6 \mathrm{~s}$

$9 \mathrm{~s}$
Capacity

175 to $250 \mathrm{lbs}$.

250 " 350 "

350 “ 450 "

450 “ 550 “

650 “ 750 “

850 “ 950 “
Price $\$ 70.00$ 80.00

95.00

110.00

135.00

150.00 
COOLEY CREAMERS With ELEVATOR ATTACHMENT

\section{TOO WELL KNOWN}

TO NEED

\section{EXPLANATION HERE}

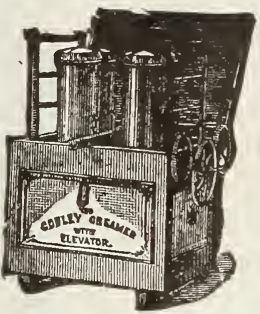

WRITE FOR SPECIAL

\section{CIRCULAR AND}

\section{SPECIAL PRICES}

Galvánized Castings
Weight 243 lbs., $\$ 70.00$

$\begin{array}{llr}\text { “ } & 320 \text { lbs., } & 95.00 \\ \text { “ } & 380 \text { lbs., } & 125.00 \\ & 480 \text { lbs., } & 150.00\end{array}$

No. 002 cans, 4 to 6 cows 25 by 31 in., 2 ft. 7 in. high.

No. 2 . manufactured

No. 2 . 4 cans, 9 to 12 cows, 31 by 37 in., " "

No. 4.8 " 12 to 18 " 2431 by 49 in., " 31 by 63 in., " "

Prices on CABINET CREAMERS' on application.

\section{COOLEY}

\section{CREAMER CANS}

\section{PRICE,}

with cover and siphon faucet, $\$ 4.50$ each.

GERM X-A cleanser and disinfectant, especially good around the dairy and stable.

$$
\begin{aligned}
& 1 \text { gallon } \$ 2.00 \\
& 5 \text { " } 8.50
\end{aligned}
$$

WOOL FAT - A wonderful healer. $1 / 2 \mathrm{lb}$. can, $50 \mathrm{c}$

$$
1 \text { lb. can, } 1.00
$$
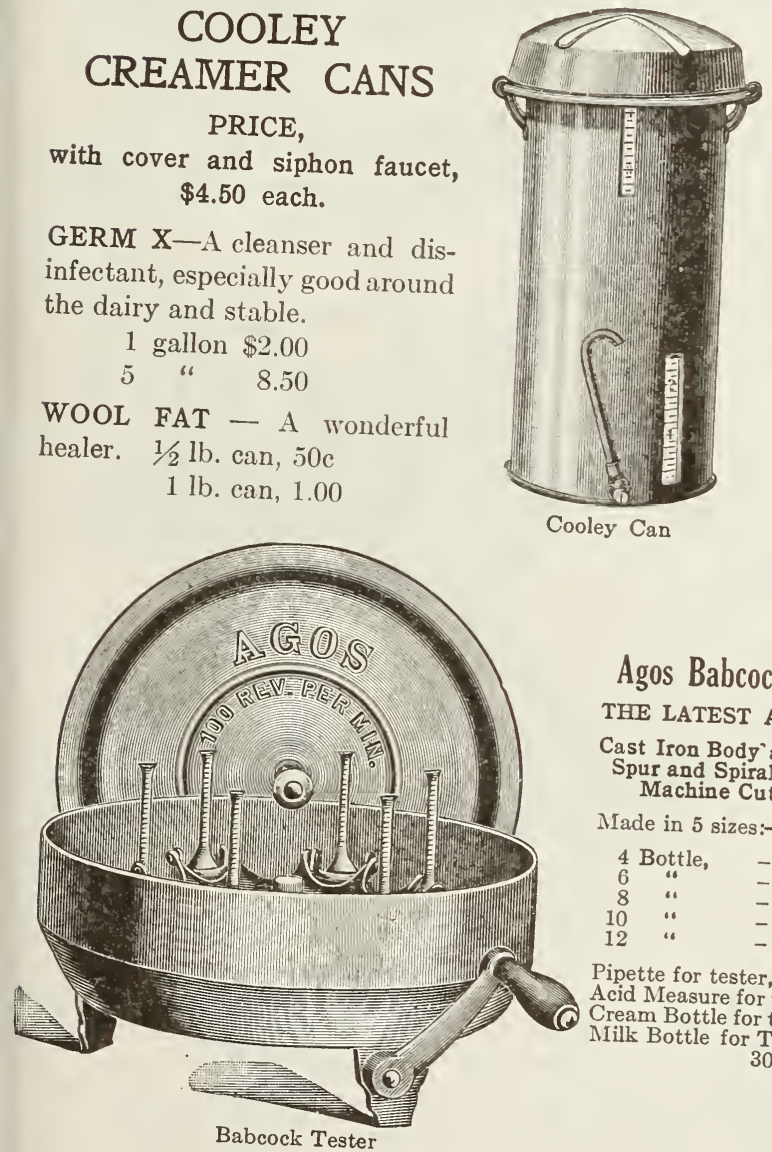

Agos Babcock Tester THE LATEST AND BEST Cast Iron Body' and Cover, Machine Cut Teeth.
Tar and Spiral Gearing, Made in 5 sizes:-

$\begin{array}{rrrr}4 & \text { Bottle, } & - & \$ 14.85 \\ 6 & \text { “ } & - & 15.40 \\ 8 & \text { “ } & - & 16.50 \\ 10 & \text { “ } & - & 17.60 \\ 12 & & - & 18.70\end{array}$

Pipette for tester, $\quad 40 \mathrm{c}$ Acid Measure for tester, 30c Cream Bottle for tester, 50c Milk Bottle for Tester $30 \mathrm{c}$ and $80 \mathrm{c}$

\section{REED CREAM CANS}

with cover and faucet, 14 qt., $\quad \$ 2.80$ $\$ 2.50$

\section{CREAM PAIIS}

With ventilated top, 20 qt. $\$ 2.00$ 24 qt. 2.45

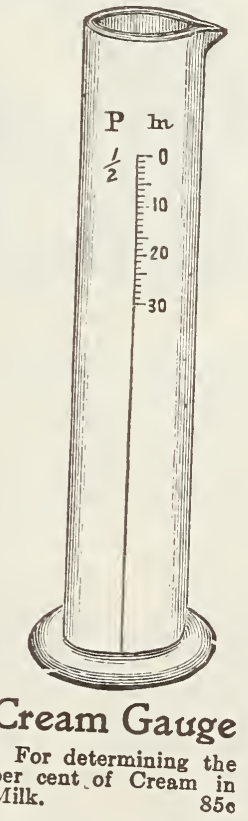

ANTI COW KICKER - Only device for breaking heifers or vicious kickers. Price, $\$ 1.35$.

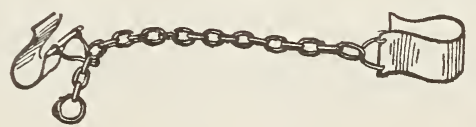




\section{BLANCHARD CHURN \\ Probably the Best Crank Churn in Use}

No. 3 Churns up to 2 gals.,........\$7.50

No. 4 " " 4 gals.,........ 9.00

No. 5 " " 8 gals.,........ 10.00

No. 6 " " " 12 gals.,........ 12.50

No. 7 " " 16 gals.,........ 15.00

SEPARATORS.-See page 62 .

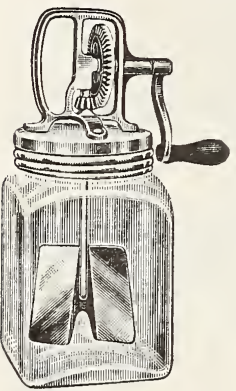

\section{LIGHTNING SANITARY CHURN}

Makes 2 lbs. butter with one pound butter and one pint milk.

Price:

$\begin{array}{llr}1 & \text { Qt. } & \$ 1.75 \\ 2 & \text { “ } & 2.25 \\ 3 & \text { “ } & 2.75 \\ 4 & \text { “ } & 3.25\end{array}$

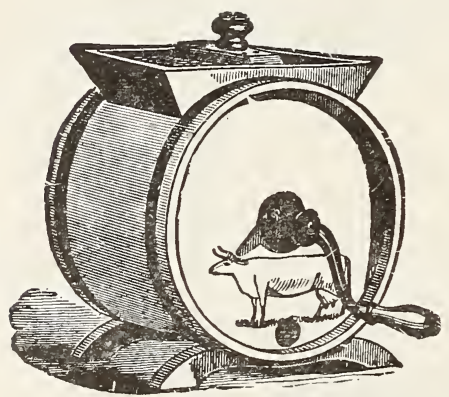

Cylinder Churn

DAVIS SWING CHURN

Easy to Operate.

Easy to Clean.

No Floats or Paddles.

One of the Best Churns Made.

Size.

No. 1

No. 2

No. 3

No. 4

No. 5

No. 6

No. 7

No. 8

No. 9

Capacity.
8 gal.,
10
16 “"
20 “"
26
34
60 “
80
100 “"

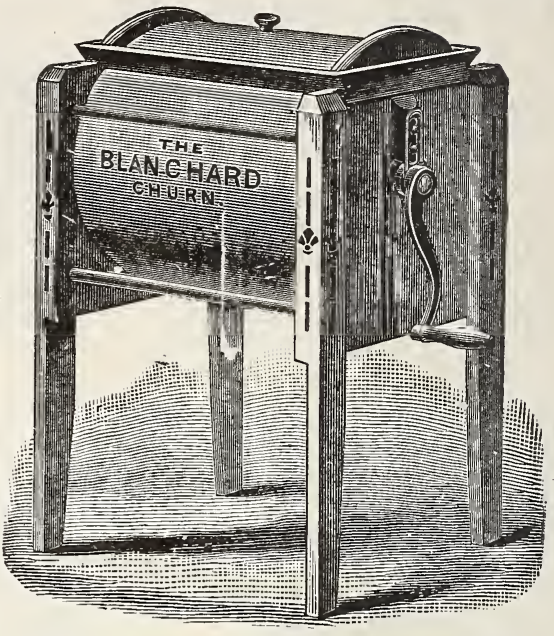

\section{CYLINDER CHURN}

A Good Low Price Churn.

Prices

No. 1 .......................... \$3.00

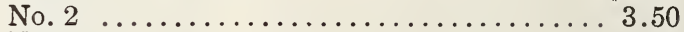

No. $3 \ldots \ldots \ldots \ldots \ldots \ldots \ldots \ldots \ldots \ldots \ldots, 4.00$

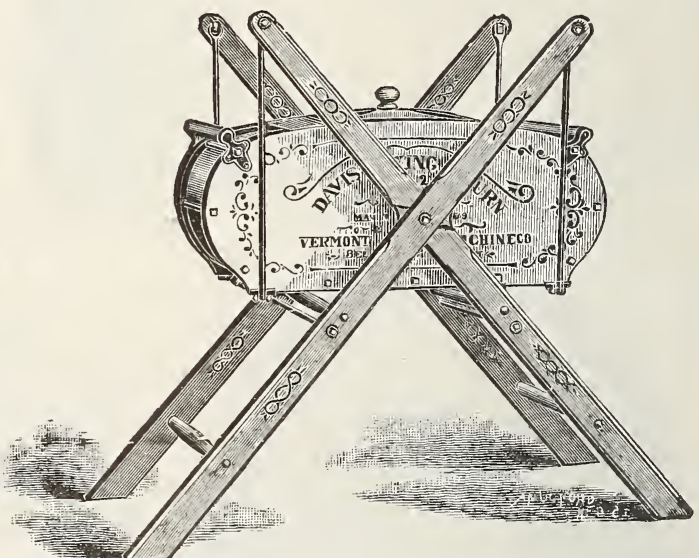

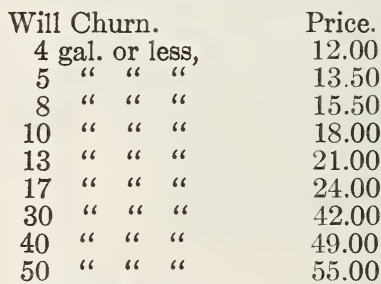

There is less liability of getting churns too large than too small. Be sure and order churns large enough. There must be room in the churn to produce the concussion, and a small churn filled too full will require a longer time for churning. 


\section{THE SURPRISE CHURN \\ Easy to Operate. Easy to Clean. No Floats nor Paddles.}

The cover fastenings never give way and let the head out. Iron parts galvanized.

No. 1 Churns from 1 to 4 gals $\quad$ Price

No. 2 " " " 2 " 7 " 7 gals. $\quad \$ 14.00$

No. 3 " " 3 " 39 " 9617.00

No. 4 " " 4 " 12 " 12 " 40.50

No. 5 " " 5 " 16 " 45.00

No. $5 \frac{1}{2}$ " " 5 " 20 " "

No. 6 " " 6 " 28 " 34.80

Extra for $12 \times 3$ pulley, $\quad 4.50$

" " tight and loose pulleys $12 \times 3, \quad 7.50$

Nos. 4 to 6 have 2 handles unless pulley is ordered, when only one handle ts sent.

Cork, for barrel churn covers, per ft. 15c.

\section{WYANDOTTE DETERGENT}

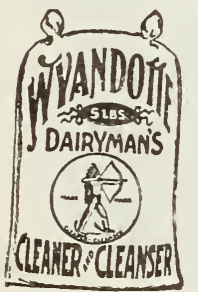

For Cleaning Marble Work, Etc.

$250 \mathrm{lb}$. Barrell,

$\$ 12.50$

Barrell of 50 5-lb.Sacks, 14.00

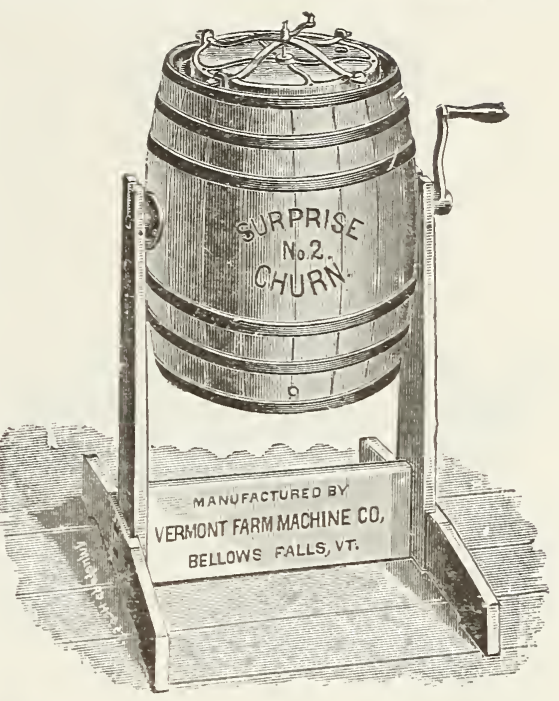

WATER'S

BUTTER

WORKER

Tray Removable,

Takes Place of

Butter Bowl.

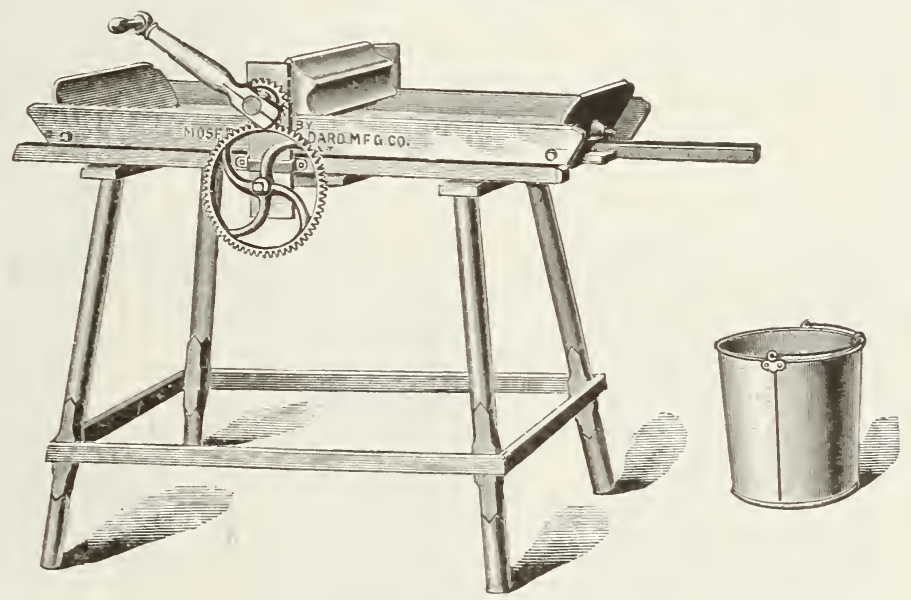

Length Width

Size of Tray of Tray Capacity No. of Cows Price

136 in 15 in.

236 in. 18 in.

339 in. 20 in.

448 in 22 in.
1 to 15 lbs. 1 to 4

5 to 30 lbs. 4 to 8

5 to $40 \mathrm{lbs}$. 8 to 12

5 to 50 lbs. 12 to 18

10 to 75 lbs. 18 to 30
$\$ 10.50$

14.00

16.00

17.50

\section{CALF FEEDERS}

Common Sense

Calf Feeders $\$ 2.00$

Common Sense

Calf Feeder Nipples 25c

\section{"Wyandotte" Dairymen's Cleaner and Cleanser}

A Splendid Washing Powder for all milk and dairy utensils.

$280 \mathrm{lb}$. Barrel,

Barrel of $50-5 \mathrm{lb}$. sacks,

$80 \mathrm{lb}$. Keg,

5 " Sack,
$\$ 14.00$

13.50

4.80

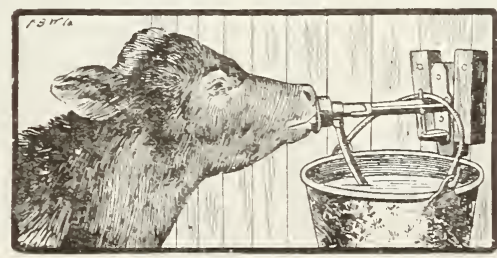




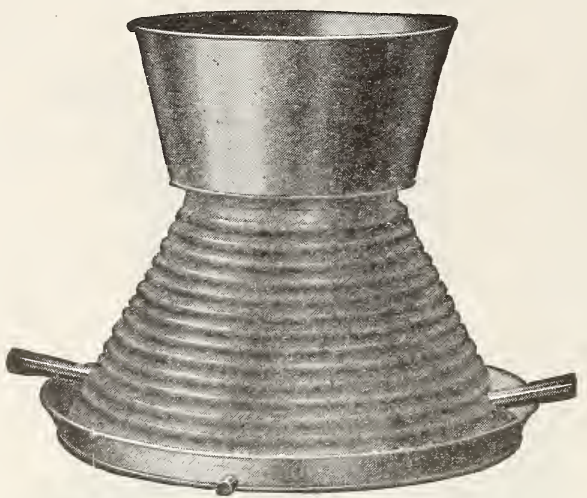

\section{Reid's Butter Shipping Box}

Capacity.

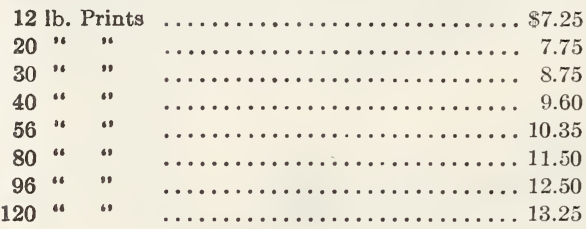

\section{SALT}

"Retsof" Lump Salt............... per Ib., \$.01 No. I, "Retsof" (best for ice cream, etc.) per bag,

$200 \mathrm{lbs}, \$ 1.75$

Cattle Salt, (coarse fine)........per $140 \mathrm{lb}$. bag, 1.50 " "(coarse fine)........ 56 per 56 lb. bag, .75

Dairy Salt, (Worcester)..........per $56 \mathrm{lb}$. bag, .90 Turk's Island Meat Salt........ 1/2 bushel sack, .75 " " " "6. " "

Roto Salt Holder.-35c each.

Dairy Salt (Leroy) per $56 \mathrm{lb}$. bag, $85 \mathrm{c}$
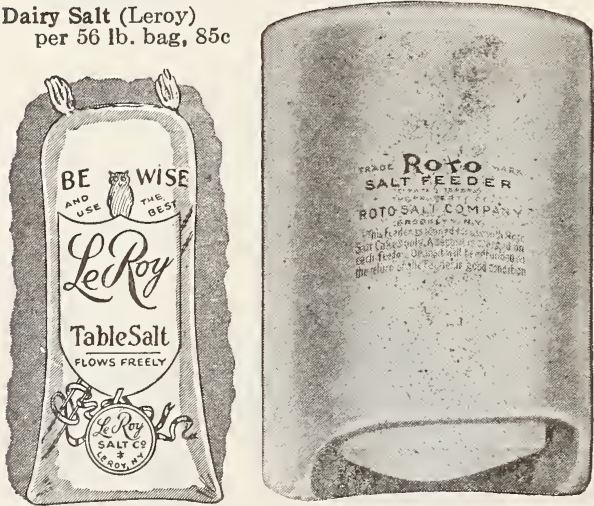

Roto Salt Cake. - 15 c each, $\$ 1.50$ per doz. Square

\section{Milk Cooler}

This is one of the best and most convenieni Coolers on the market. It not only cools the milk but aerates it. The illustration is not absolutely correct, but gives an idea of the method of cooling.

No. Capacity of Size of

Milk Receiver. Dairy.

Price.

218 qt. 10 to 25 cows $\$ 11.00$

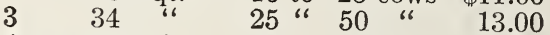

452 “ 50 “ 100 “ 16.00

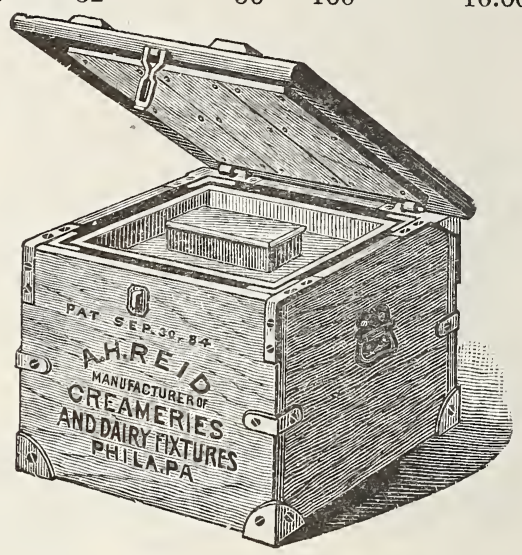

Thatcher's

Orange Butter Color

Small Bottles........................ \& .25

Large Bottles............................ \$. .50

One Quart Cans........................ 1.00

\section{Wright Milk Bottle Filler}

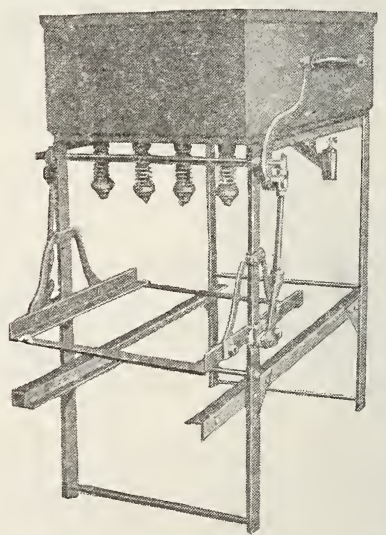

Made with Galvanized Steel frame, tinned copper tank, and sanitary fittings. Bottles filled perfectly with no topping off or overflow.

No. 4-filler )

$\left.\begin{array}{r}9-\text { "iller } \\ 32\end{array}\right\}$ Prices on application.

Bottle Cases, quarts, with bottom corner irons and retainers, $3 \times 4$,

Pints, with bottom corner irons and retainers,

\author{
2.00
}

2.10 
FRANK HOWARD, PITTSFIELD, MASS.

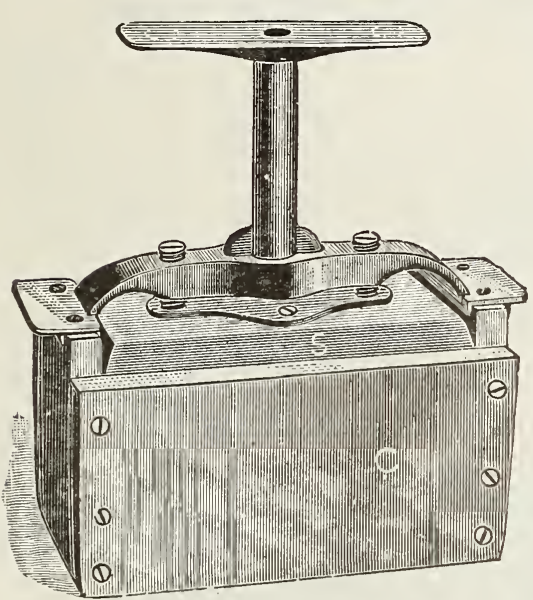

No. 2 Butter Molds
Butter Moulds

No. 2 Mould, Price $1 \mathrm{lb} ., \$ 3.00$

Daisy Mould, $1 \mathrm{lb}$ $\$ 1.50 ; 1 / 2 \mathrm{lb}$., $\$ 1.25$

Commonsense Mould,

$1 \mathrm{lb}$., $\$ 1.00$

CARVING.-Any name.

monogram or design

carved on moulds to order.

Butter Ladles,

Price $15 c \& 20 c$

Flat Butter Spades, plain, Price 10c \& 20c Concave Butter Spades, plain, Price 15c Butter Spades, creased, Price $10 \mathrm{c}$ and $15 \mathrm{c}$ Milk Measures,-Tin, accurate will seal, $1 / 2$ pt. $35 \mathrm{c}, 1$ pt. $40 \mathrm{c}, 1$ qt. $50 \mathrm{c}, 2$ qts. $75 \mathrm{c}, 4$ ats. $\$ 1.35$

Milk Dippers, 650 Measuring Rods for 2030 and 40 qt. cans,

Central Strainer Pail-Detachable strainer, heavy, ...... \$2.00 \& $\$ 2.25$ Heavy Tin Milk Pail-14 quarts........................ Common Strainer Pail, ........ 1.75 Sterilac Milk Pail,-Sanitary, all

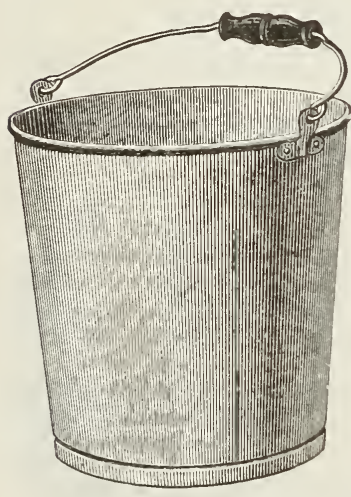

MILK PAIL parts clennable,

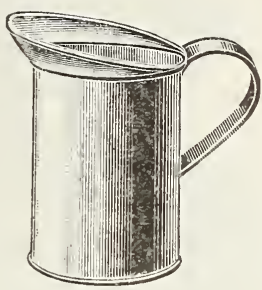

Milk Measure

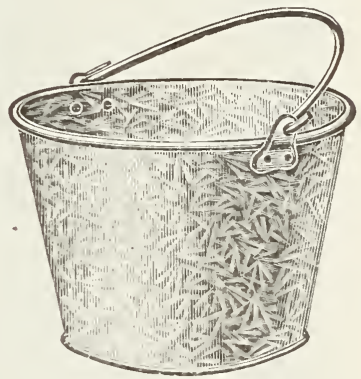

Mule Pail $\$ 1.00$

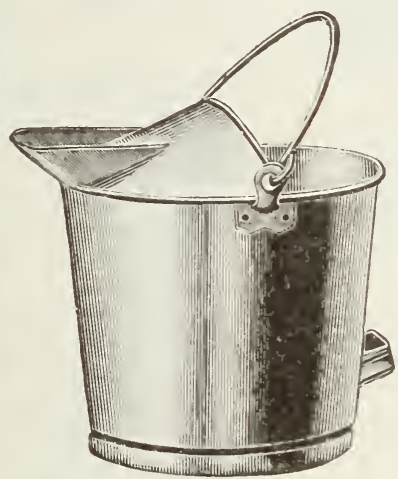

STRAINER PAII

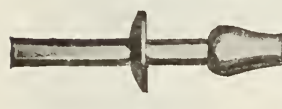

\section{MILKING TUBES}

Plated, 25, 30 and $35 \mathrm{c}$.

CATTLE LEADERS, 40c. $\$ 1.25$.

Stricture Cutters, $\$ 1.50$.

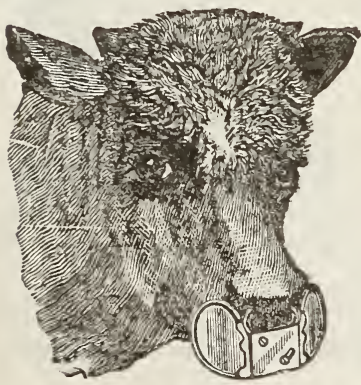

CATTLE CARDS, Common Size, 25c large size 30c. W BELLS, No. I, \$1.25; No. 2 $\$ 1.00 ; \mathrm{No} .3,85 \mathrm{c}$.

SHEEP BELLS $35 \mathrm{c}$ and $50 \mathrm{c}$.

WEANERS, Small Calves, 50c; Medium Yearlings, $75 \mathrm{c}$; Large Cow, \$1.00.

OX MUZZLES, heavy, 50c Per Pair.

BULL RINGS, Copper, Medium, 45c; Copper, Large, 50c; Cannon Metal, very heavy, \$1.75. PUNCH, $\$ 3.00$

RUBBER APRONS, Heavy, $\$ 1.75$ and $\$ 2.25$

RUBBER MOP OR SQULLGEE, $\$ 1.00$ and $\$ 1.20$.

WOOD STABLE FORK (best), $\$ 1.00$.

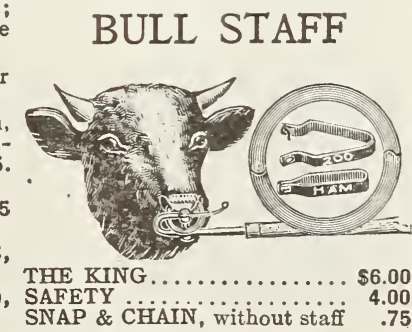

THE KING $\ldots \ldots \ldots \ldots \ldots \ldots .00$ $\begin{array}{lr}\text { SAFETY } \\ \text { SNAP \& CHAiIN, without staff } & 4.00 \\ .75\end{array}$

\section{BULL STAFF}




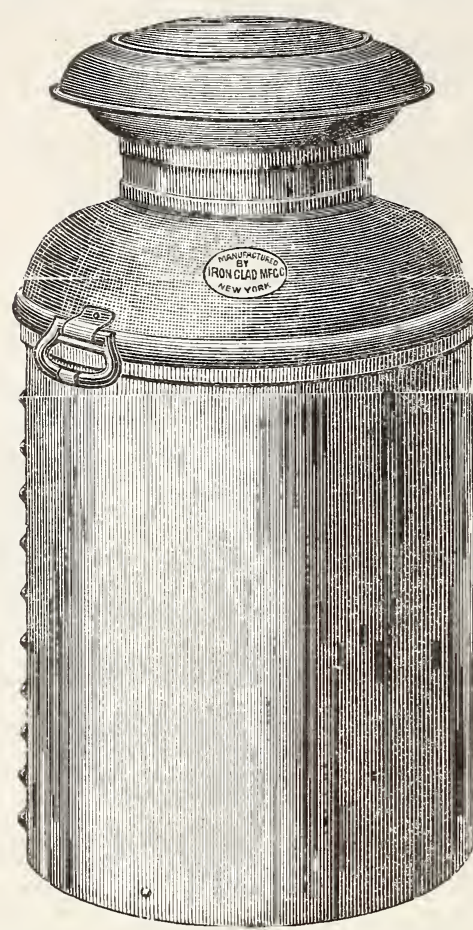

Railroad Milk Can New York Pattern

\section{RAIIROAD MILK CANS} NEW YORK PATTERN

20 Quart ..............................\$6.25

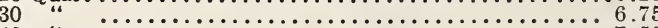
40

Special price to milk dealers using quantities.

SPECIAI ATTENTION is given to supplying Combination Shipping Cans for milk, butter, eggs, cream.

\section{RAIIROAD IMILK CANS}

SPECIAL DELIVERY PATTERN WITH CHAINS

12 Quart plain $\ldots \ldots \ldots \ldots \ldots \ldots \ldots \cdots \cdots \cdots+$ Prices on Applications.

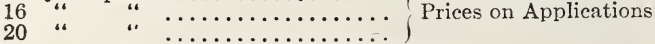

PADLOCK EXTRA

Extra for Cream Compartment.

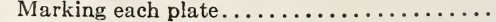

\section{IVILK PANS-Heavy Tin}

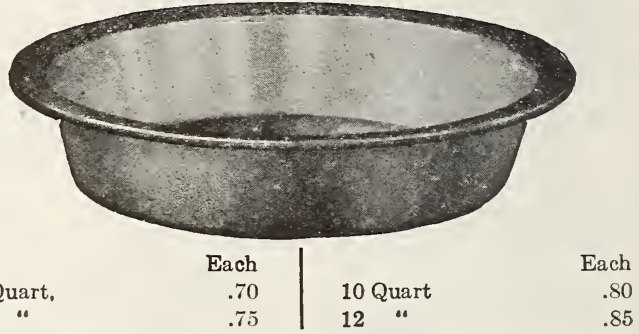

Boston Milik Can, City Delivery Pattern

$\begin{array}{llllllll}\text { Quarts......... } & 1 & 2 & 3 & 4 & 6 & 8 & 10\end{array}$

$\begin{array}{lllllll}\text { Price Heavy Tin } 60 \mathrm{c} & 75 \mathrm{c} & 90 \mathrm{c} & 1.00 & 1.50 & 1.75 & 2.25\end{array}$

" $1 \mathrm{C}$ " $35 \mathrm{c} \quad 50 \mathrm{c} \quad 60 \mathrm{c} 75 \mathrm{c}$

\section{SPECIAL MIIK STRAINER}

An excellent strainer, in fact the best and easiest to keep clean that we have found. Price, Medium size, $\$ 1.25$; Large size, 1.75 COMMON STRAINER....................50c

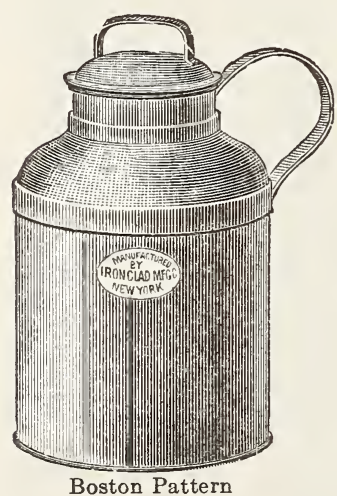

WOOD BUTTER BOWLS

Best Quality, 13 inch Price $\$ .75$

" " 15 inch " 1.25

" " 17 inch " 1.75

" " 19 inch 1.25 and 2.00

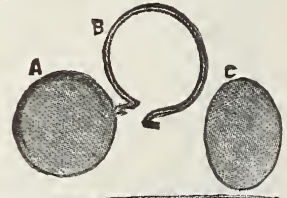

OX BUTTON, Octagon. (See cut), 20c per pair.

ox BUTTON, Tall Pattern, 50c per pair.

\section{WEATHER VANES}

Special Illustrated Sheet of Designs and Prices sent on application.

\section{BLATCHFORD'S CALF IMEAL}

$\begin{array}{rlllllll}25 \mathrm{lb} . \mathrm{Bag}, & - & - & - & - & - & - & \$ 1.65 \\ 50 \mathrm{lb} . \mathrm{Bag}, & - & - & - & - & - & - & 3.00 \\ 100 \mathrm{lb} . \mathrm{Bag}, & - & - & - & - & - & - & 6.00\end{array}$

CALF CORDIAL, - - - - - pkg. 75c

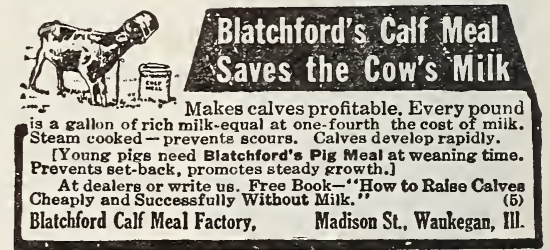




\section{PLATFORIM SCALE}

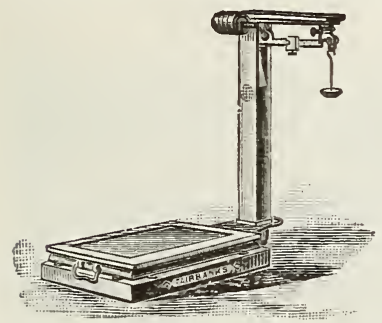

A very accurate scale, especially good for farmers' use.

Capacity 600 lbs., $\$ 33.00$

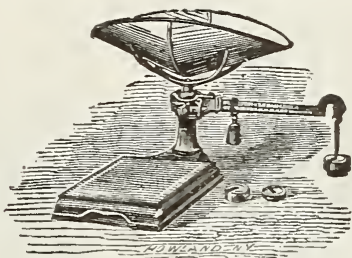

FAIMILY OR DAIRY SCALES

Capacity, $1 / 2$ oz. to 240 lbs., positively accurate, with platform and brass scoop, Price $\$ 16.00$

Ice Scales, Chatillons, weighs from 5 lbs. to 200 lbs., Price 3.00

\section{DIAL SCALE}

Weighs up to 25 lbs., enameled top.................... $\$ 1.50$

Special Milk Scale weighs 30 lbs. by ounces, . . . . . . . . . . . . . .4.50

Special Milk Scale weighs 60 lbs. by 2 ounces, . . . . . . . . . . . . . 5.00

Special Milk Scale weighs 60 lbs. by tenths, ... . . . . . . . . . 5.25

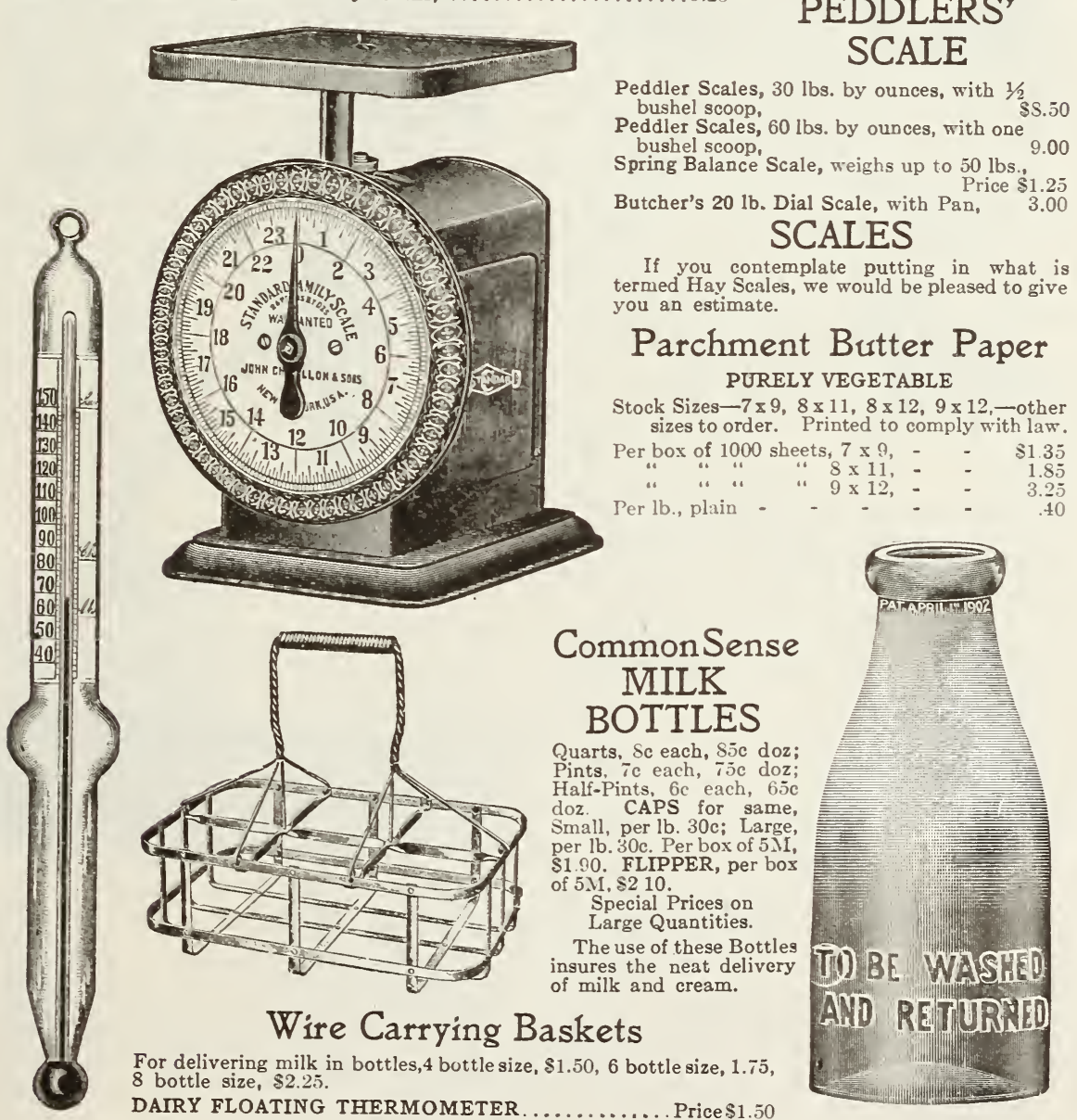




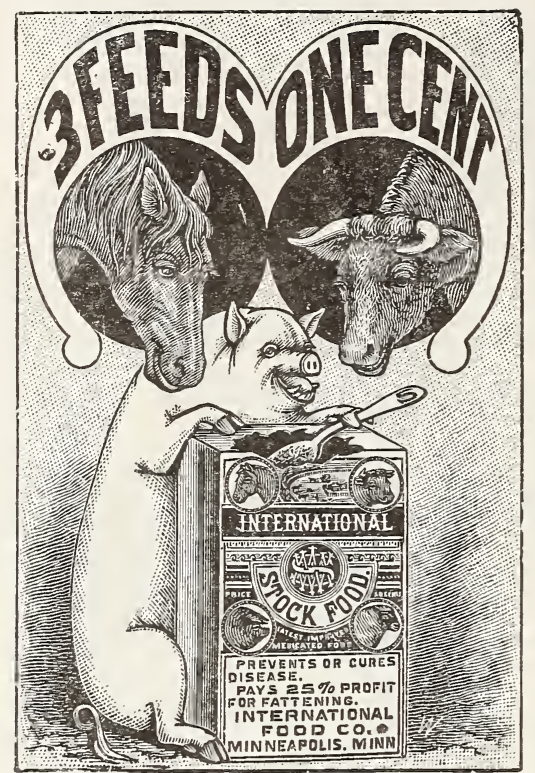

\section{INTERNATIONAL STOCK FOOD}

This food we find gives excellent satisfaction.

Price per small package................\$ .30

" medium "

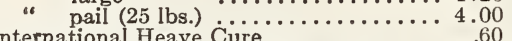

International Heave Cure $\quad .60$

International Hog Worm Powder, pkg... caused by garget, injury, overfeeding, etc., per pkg., 75c and $\$ 1.50$.

WHITE ROCK HOOF PACKING.-An excellent article.

Small size ................ $\$ .25$

Medium ............... $\quad .50$

Large ........................ 1.00

KOWKURE.-A medicine for cows only.

Prices, small can, 55c; large can, $\$ 1.10$.

GRANGE GARGET CURE.-For the cure of milk fever and garget. Price 55c PRATT'S ANIMAL REGULATOR. Very reliable, per pkg....60c and $\$ 1.00$ SILVER PINE HEALING OIL.-Per bottle ...............6. 60 REFINED PINE TAR.-Per can $15 \mathrm{c}$ and $25 \mathrm{c}$.

COAL TAR.-Pt. can 20c, qt. 35c, gal., 65c

\section{Whiffletrees, Eveners, Neck Yokes}

These we have made for us out of firstclass timber, and the trimmings are of forged steel.

NECK YOKES. - Short, each ............ \$2.00

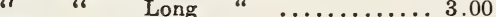

EVENERS.

WHIFFLETREES. each $\ldots \ldots \ldots \ldots \ldots \ldots \ldots 2.00$ EVENERS AND WHIFFLETREES.-

Per set............................. 7.00

EVENERS. -Factory made............ 1.50

WHIFFLETREES " ............. 1.00

NECK YOKE Factory made..................

\section{CHAINS}

STAKE.-Heavy, short link, per pair,...... \$2.00 SHORT TRACE.-Medium, per pr. ....... 1.00 SHORT TRACE.-Very heavy, per pr...... 1.25 LONG TRACE, per pr................. 1.75

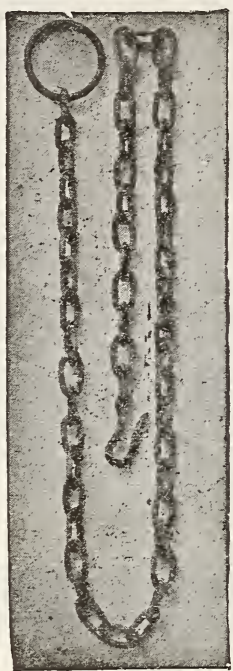

LOG OR STONE CHAIN. Prices on Application

$\frac{3}{8}$ in $\times 12 \mathrm{ft}$, 1 grab hook, 1 common hook,

$7-16$ in. $\times 12 \mathrm{ft}$., 1 grab hook, 1 common hook, 7-16 in. × $14 \mathrm{ft}$., 1 -grab hook, 1 common hook $1 / 2$ in. $x 14 \mathrm{ft}$., 1 grab hook, 1 common hook LOG :CHAIN.-

$\frac{3}{8}$ in. $x 12$ ft., hook and ring,

$7-16$ in. $x 12 \mathrm{ft}$., hook and ring, 7 in. $x 14 \mathrm{ft}$. , hook and ring,

$1 / 2$ in. $\times 14 \mathrm{ft}$., hook and ring,

Ruggle Chain

$\$ 5.50$ and 7.00 STONE BOAT OR DRAG. Prices from $\$ 7.00$ to 1100 STEEL CROW BARS.Per lb., 13 STONE BOAT FRONT.plank,

32 in. with bolts, 4.50 34 in. with bolts, 4.75 40 in. with bolts, $\quad 5.85$

\section{CANT. OR LOG HOOKS}

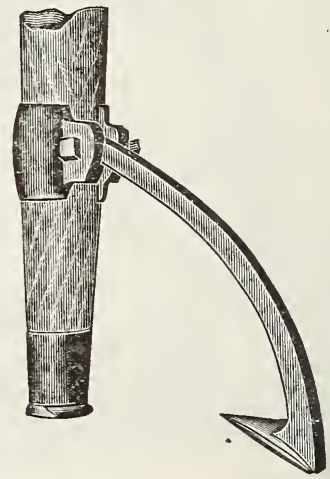

Vermont Pattern, light............... 3.50 Vermont Pattern, light.................. 4.50 Maine “ heavy $\ldots \ldots \ldots \ldots \ldots \ldots \ldots, 4.00$ TIMBER CARRIERS, - each............ 3.00

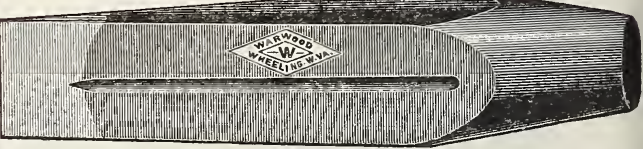

SPLITTING WEDGES.-

Round head, per lb............... .17

SPLITTING WEDGES.-

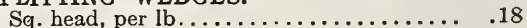

WOODCHOPPERS' 'MÄUL.-

Steel, per lb.................... .30 SLEDGES.-Steel, per lb. ............. $\quad .25$ STONE HAMMER “ $\ldots \ldots \ldots \ldots \ldots \ldots \ldots .35$ HAND “ $"$ " WEDGES AND SHIMS.-Per $\mathrm{ib} \ldots \ldots \ldots \ldots . .35$ 


\section{P A I NT}

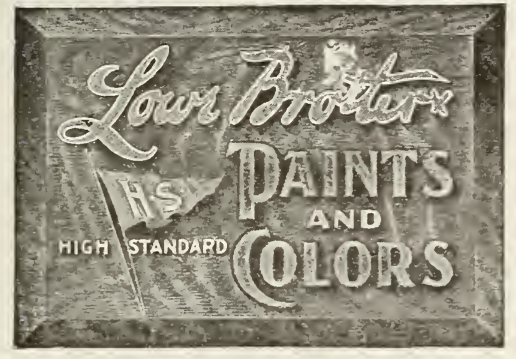

"LOWE BROTHERS' 'High Standard' P AIN T S.'" These Paints are BEAUTIFUL GOODS. They have COVERING POWER, SPREADING CAPACITY, DURABILITY and are SPLENDID COLORS and FULL MEASURE. Watch for the LITTLE BLUE FLAG on the can, it insures good paint and satisfaction A paint for every need. Get our colors cards.

LOWE BROTHERS' VARNISHES-Excellent goods in six kinds. VERNICOL-A splendid varnish stain, makes a beautiful finish.

LINSEED OIL-In any quantity desired.

TURPENTINE - In any quantity desired.

VALSPAR - An especially fine

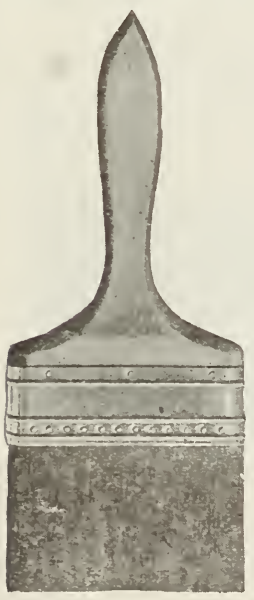
varnish, $\mathrm{h}$ ot water does not turn it white. In convenient size cans.

PAINT BRUSHES

Fine line of paint and Varnish Brushes "Elastic General Purpose," "Quick Action House," "Interior House," "Durable Floor," "Spar Varnish," and "Crystal Finish" all packages carry the little blue flag denoting quality.

LOWE BROTHERS' "MELLOTONE," Flat Colors for Interior Decoration on Woodwork and Walls, Rich, Mellow, Beautiful, Permanent, Washable.

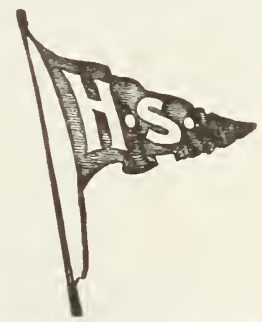

This Little Blue Flag on every can

\section{PUTTY}

WHITE LEAD PUTTY

$1 \mathrm{lb}$. Can subject to change, $12 \mathrm{c}$

5 " " " " " " 750

$121 / 2 \mathrm{lb}$ " " " " $\$ 1.25$

$25 \mathrm{lb}$ " " " " 200
LINSEED OIL PUTTY

$1 \mathrm{lb}$. Can subject to change, $12 \mathrm{c}$

j" " " " " " $" 50 \mathrm{c}$ 10 " " " " " $490 \mathrm{c}$

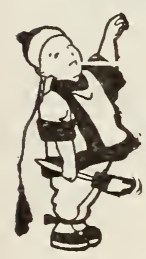

\section{Chi-namel}

A S F OR C OLOR CAR D

CHI-NAMEL. For Staining and Varnishing in one operation, also Graining. AN EXCELLENT ARTICLE.

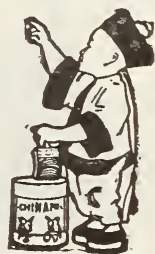




\section{GENUINE CYPHERS INCUBATORS}

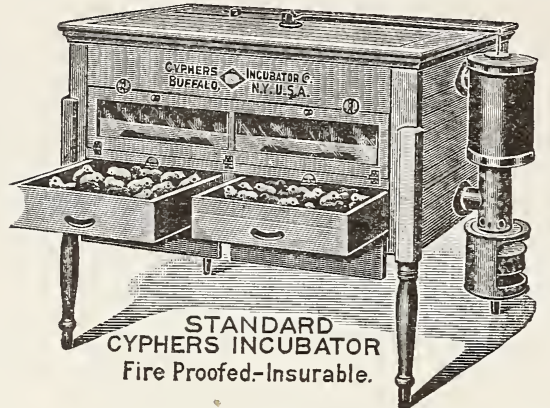

Practical poultry raisers who desire the greatest possible success should look for and DEMAND the qualities that have made Cyphers Incubators

WORLD-FAMOUS.

FIRE-PROOFED

INSURABLE

SELF-VENTILATING

SELF-REGULATING

NON-MOISTURE

EFFICIENT, DURABLE and POSITIVELY GUARANTEED.

PRICES OF CYPHERS FIRE-PROOFED INCUBATORS

No. 1 Holds 144 Hens Eggs 32.75

No. 2 Holds 244 Hen Eggs

$\$ 47.00$ No. 3 Holds $\mathbf{3 9 0}$ Hens Eggs 56.00

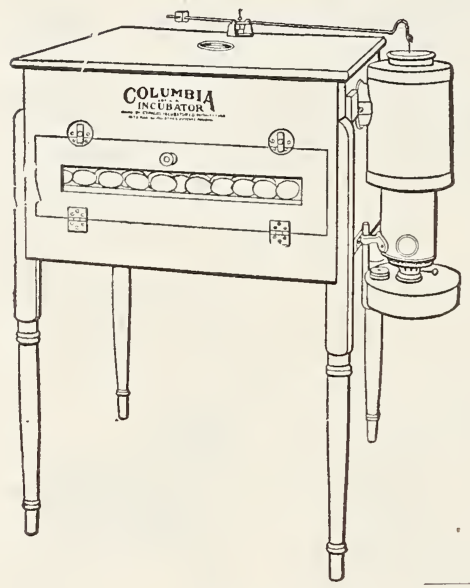

\section{THE COLUIMBIA INCUBATORS}

A splendid hatcher, very much liked. These Incubators have not advanced in price in proportion to many others and on this account and because they are a first class incubator and top notch hatchers, we anticipate a large sale.

$\begin{array}{ll}\text { Small size, } & 140 \text { Egg capacity } \\ \text { Large } & \$ 20.00 \\ 250 & \end{array}$

\section{SUPERIOR HOT-WATER} INCUBATOR (Cyphers)

\section{PRICES}

Superior Small size, 65 Egg capacity - $\$ 13.00$

\section{STANDARD CYPHERS BROODERS and Colony Roosting Coops}

Are self-regulating, self-ventilating, FireProofed and Insurable. Easily converted into colony roosting coops by simply removing the hover.

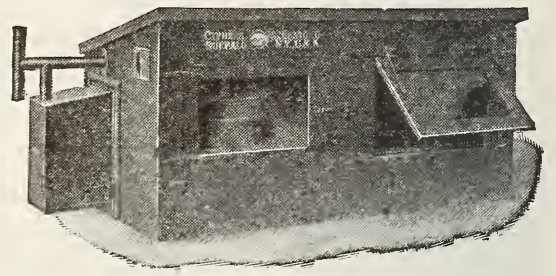

Prices:

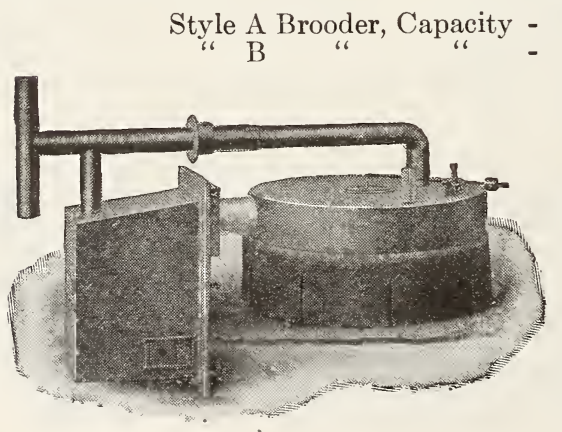

\section{ADAPTABIE HOVER Mothers the chick \\ better than a hen}

Self-Regulating, Self-Ventilating, complete with Regulator and Thermometer and bearing Underwriters' Label, $\$ 14.00$. 


\section{THE BANNER INCUBATOR}

A splendid hatcher, built of California Redwood, double walled. Hatches healthy chickens from every hatchable egg.

Prices:

Banner No. 1-150 Egg Capacity

25.00

" "2-300 " "

38.00

\section{Parcel Post Egg Box}

PARCEL POS'T EGG BOX. -Capacity 1 doz., $10 \mathrm{c}$ each, $\$ 100$ doz. Capacity 5 doz., $35 \mathrm{c}$ each.

PARCEL POST EGG BOX. -(for settings)-Capacity 15 eggs 20c each.

PARCEL POST DAY OLD CHICK BOXES-25 chick size, $35 \mathrm{c}, 50$ chick, $50 \mathrm{c}$; 100 chick, $75 \mathrm{c}$;

EGG CARTONS.-(Capacity 1 doz.)-doz. 12c, per 100, 90c.

WATER GLASS.-For preserving eggs, one gallon preserves 50 dozen eggs. Per qt., $35 \mathrm{c}$; per gallon, $80 \mathrm{c}$

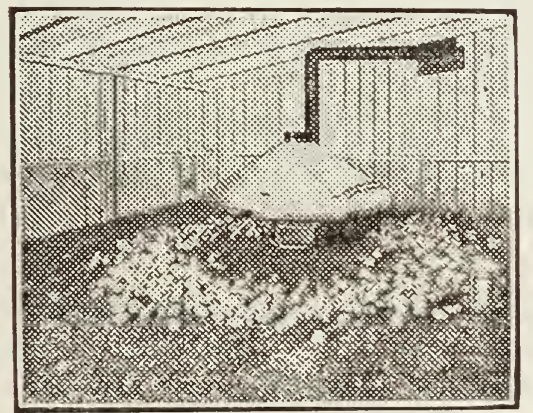

Newtown Giant Coal-Burning Colony Brooder

Automatic coal feed, simple, safe, economical. Price N8. 10-for 300 chickens - $-\$ 25.00$ Price No. 11-Little Giant for 500 chickens - - - - $\$ 30.00$ Price No. 12-Giant for 1500 chickens $\$ 38.50$ Price No. 7-Premier
OLD GRIST MILL DOG BREAD

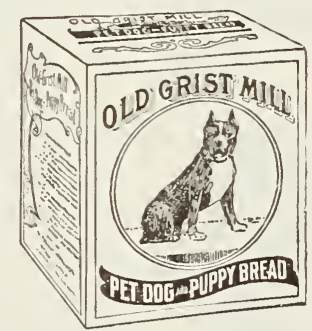

$1 \mathrm{lb}$. Puppy .............. \& 12

$3 \mathrm{lb} . \operatorname{Dog} \ldots \ldots \ldots \ldots \ldots \ldots \ldots . .30$

50 lb. Bag Dog.............. 5.00

\section{DOG BREAD-Austin's}

Puppy,

Dog,

\section{MILK BONE-Maltoid} Puppy, Dog, 


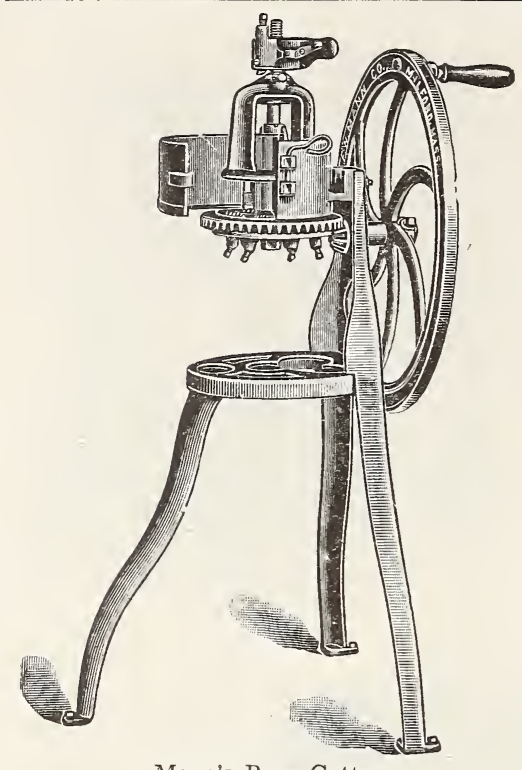

Mann's Bone Cutter

Chicken Feed Cutter

Cuts 1-4, 7-16, 3-4 inches.

Has three $61 / 4$ inch knives and is a rapid cutter - - - Price $\$ 23.00$. Nest Eggs

China, per dozen,

Adjustable, Climax or Eclipse Leg Bands

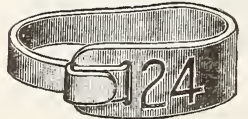

Per dozen, $15 \mathrm{c}$, Per 100, .75

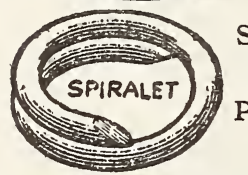

Spirol Leg Band, per dozen, $15 \mathrm{c}$, per $100,75 \mathrm{c}$

Poultry Punches, $25 \mathrm{c}$ and $50 \mathrm{c}$

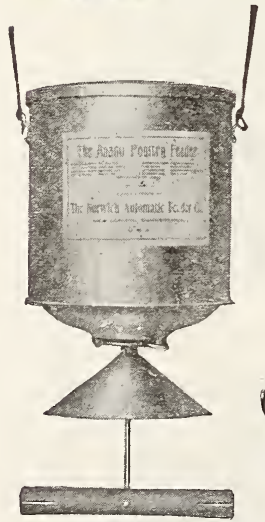

The APACO FEEDER and Exerciser, \$1.50 The Norwich Feeder and Exerciser, with adjustable standards, No. $1, \$ 3.00$; No. 2 , 3.90 ,

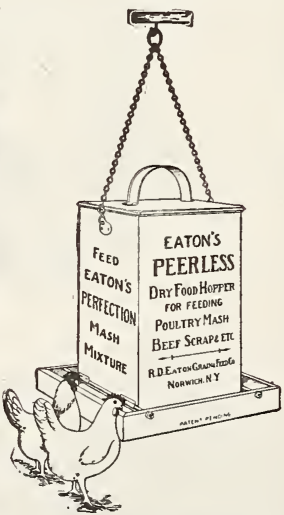

PEERLESS FEED HOPPER

suspends from ceiling

8 Qts., - - $\$ 1.50$

16 " - - -2.00

32 " - - - 2.75

\section{THE IMANN BONE CUTTER}

For Grinding Green or Dry Bone, An Excellent Machine

Our Price.

No. 5-C. With crank,

$\$ 9.00$

No. 5-B. " balance wheel, 12.50

No. 5-B-M." " " and stand, 16.00

No. 7-B. " " " " 18.50

No. 71/2. Semi-Power, $\quad 25.00$

No. 9. With bal. wheel and stand, 28.50

No. 11. Power Machine, 40.00

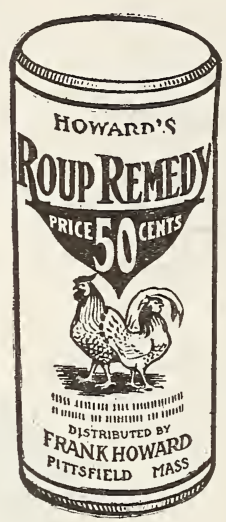

Howard's Roup Remedy

A medicine of merit,

Per Box - . - - - 60c Pratts Roup Cure, 30c, 60c Dr. Hess Roup Cure, 30c

\section{Conkey's Roup Cure}

Per box, -. - 30c and 60c Conkey's Cholera Cure 60c Conkey's Gape Cure, $60 \mathrm{c}$

WIRE HENS' NESTS. Each 20c. Per doz., \$2.00. The 1-2-3 DRY FOOD HOPPER for Feed $\$ 1.25$

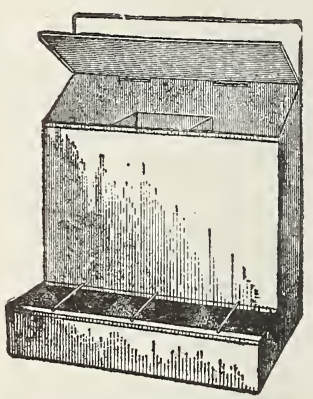

The 1-2-3 Feed Hopper for Shells, Grit, etc., $90 \mathrm{c}$.

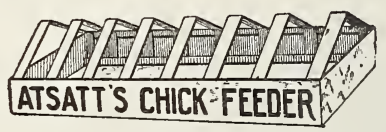

Price $35 \mathrm{c}$

\section{Egg Testers}

Each,

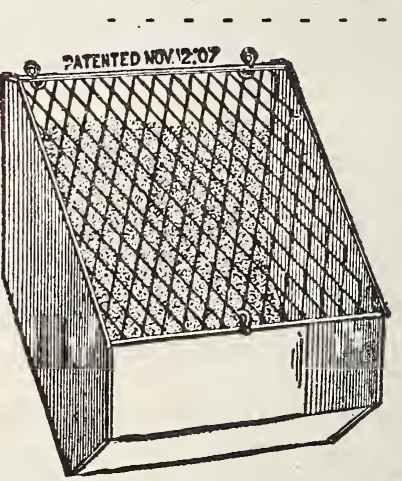

Boston Feed Hopper, - - - - $\$ 1.50$

Boston Feed Hopper, long chick size, 1.75

OAT SPROUTER.-6 Trays and Rack, $\$ 6.00$. 


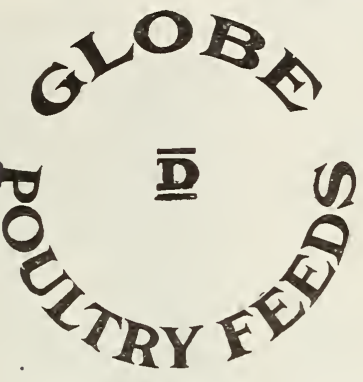

No Grit. No Waste.

Globe Chick Feed.-A mixture of small grains and seeds which make a complete balance ration for young chicks. Contains no grit. Prices variable according to grain market.

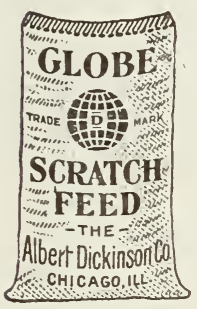

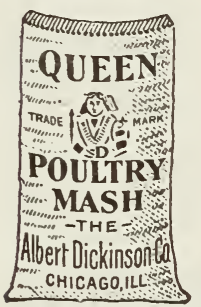

Globe Scratch Feed.-

Composed of specially cleaned sweet grains, whole and cracked, also sunflower seed, oil cake and charcoal. Nogrit. No waste. Prices variable according to market.

Queen Poultry Mash.-A select mixture of ground feeds from sweet, wholesome grain, it is a growing and health food, a molting food and an egg producer. Price variaable according to market.

Globe Developing Feed.No Grit.-For promoting the growth of chickens. following the period of Globe Chick feeding. Prices according to market.

MILK-WASH-(Blackford's) for young chicks and growing chicks, per $100 \mathrm{lb}$. bag, \$6.50, per lb., $8 \mathrm{c}$.

\section{GROUND CHARCOAL}

For Poultry-2 lb. box 15c, 2 for $25 \mathrm{c}$; $50 \mathrm{lb}$. bag $\$ 2.25$ : per $100 \mathrm{lb}$. bag, $\$ 4.00$.

\section{POULTRY GRIT}

No. 1-Coarse for Poultry,

No. 2-Medium,

No. 3-Fine, for Chicks,

Price per $100 \mathrm{lb}$. bag, $85 \mathrm{c}$

CLOVER-Shredded Alfalfa, $50 \mathrm{lb}$. Bag, \$2.00; 100 lb. Bag, \$3.50.

\section{International Poultry Food}

This food is giving exceptionally good satisfaction. Price per package, 30c, 60c, and $\$ 1.20$.

\section{Pratt's Poultry Food}

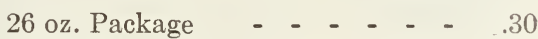

5 lb. Package, $\quad-\quad-\quad-\quad-\quad 60$

12 lb. Pail, _ - - - - - 1.75

\section{Pratt's Baby Chick Feed}

Excellent for little chicks. Per package $30 \mathrm{c}, 60 \mathrm{c}$ and $\$ 1.25$.

Lee's Egg Maker.-Per pkg., 30c and 60c

"Germozone.-" " $65 \mathrm{c}$

\section{Sheridan's Condition Powders}

An Egg Producer of merit. Small package, 25c. $2 \frac{1}{2} \mathrm{lb}$. Can, $\$ 1.00$.

\section{Dr. Hess Poultry Pan-a-ce-a}

$11 / 2$ lb. pkg. 30c. 12 lb. pkg. \$1.25.

5 lb. pkg. 60 c. 25 lb. pail $\$ 2.50$.

\section{Sea Shells}

Per 100 lb. bag $\$ 1$; per peck, .40; per qt., .07

\section{Ground Beef Scraps}

100 lb. bag................. \$5.50

$25 \mathrm{lb}$. bag. ............... 1.50

\section{Protox Brand Scraps}

100 lb. bag................. \$7.00

\section{Ground Oyster Shells}

Per 100 lbs.,.............. $\$ 1.00$

\section{Bone Meal}

For cattle or poultry, per 100 lbs., . . $\$ 4.00$ Per 25 lbs.,................ 1.00

\section{Cracked Bone}

$100 \mathrm{lb}$. bag................\$4.00

$25 \mathrm{lb}$. bag................. 1.00

\section{STERIINGWORTH DIARRHOEA REMEDY}

Cures and prevents diarrhoea including white diarrhoea. A powder for use in drink. Price $3 \mathrm{Cc}$ and 50c. 
FRANK HOWARD, PITTSFIELD, MASS.

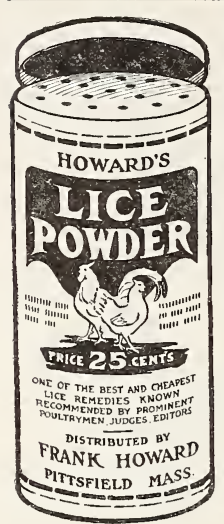
DEATH TO LICE POWDER

This has given excellent satisfaction, doing perfectly the work intended.

Small Package ............................ \$

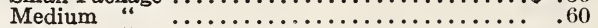
Large

\section{LIQUID LICE KILLER}

This is a liquid insecticide for destroying lice on poultry, stock, etc., and is an excellent article, very easy to use, and does its work thoroughly. It is also a disinfectant.

Price 1 Quart Can.................... .45

“2 “ 2 ".................. 75

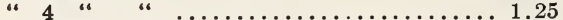
KIII GERM DIP-For dipping sheep and for lice on cattle and hogs. Quart 50c; 1/2 Gal., 90c.

DR. HESS LICE KILLER

I lb. pkg. 30c

Sulphur Fumigating Candles, Each 15c.
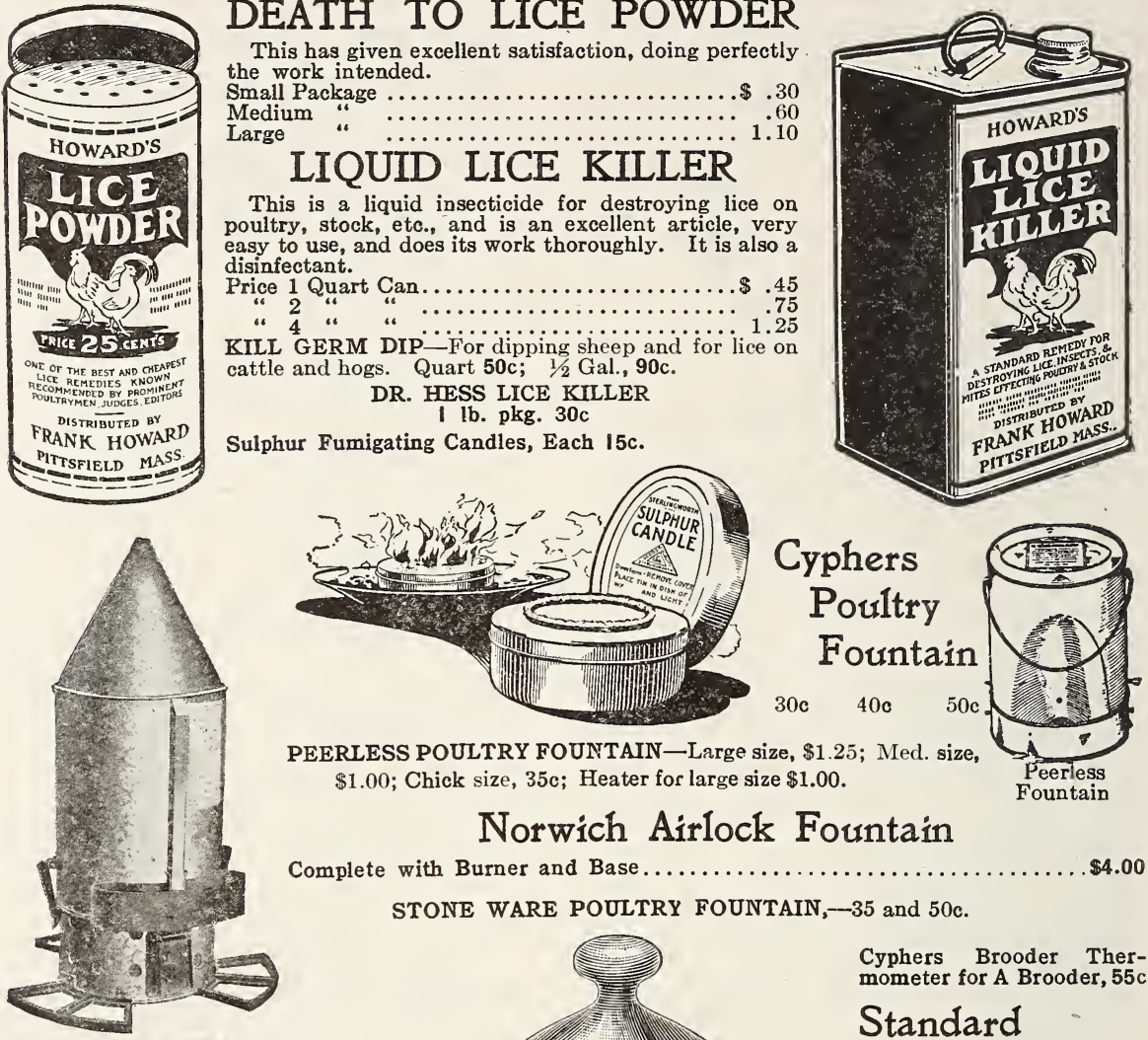

PEERLESS POULTRY FOUNTAIN-Large size, \$1.25; Med. size,

$\$ 1.00$; Chick size, 35c; Heater for large size $\$ 1.00$.

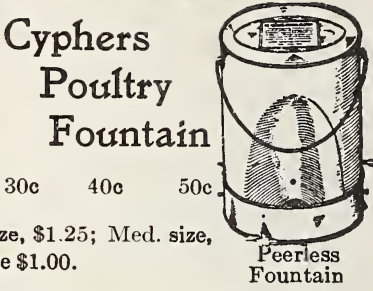

\section{Norwich Airlock Fountain}

Complete with Burner and Base.

$\$ 4.00$ STONE WARE POULTRY FOUNTAIN, -35 and 50c.

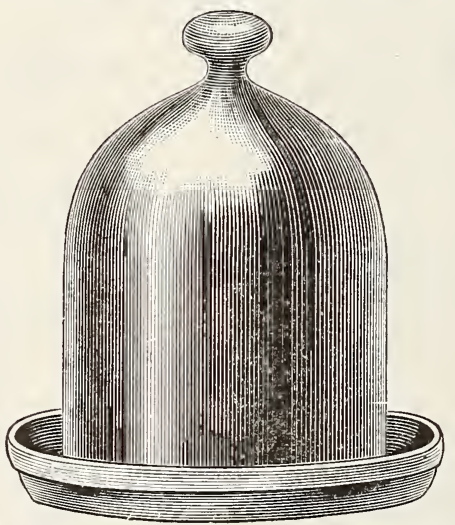

Cyphers Brooder Thermometer for A Brooder, 55c

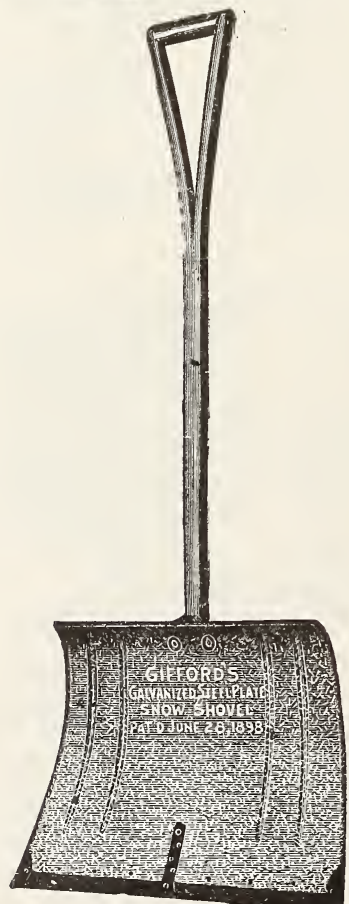

Standard Incubator Thermometer

Price $75 c$

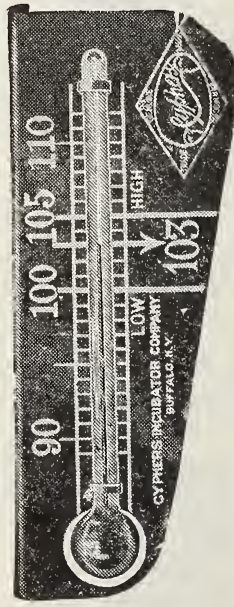

Boys' Rural $11 \times 14$ inch Sheet iron tip.....35c Cole $\quad 16 \times 20$ inch Steel edge tip.... 85c All Steel.......................\$1.00

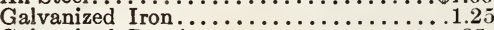
Galvanized Boys'..................35c

Sidewalk Chisels (Socket Forged)..60c \& 75c Incubator Hygrometer ............\$1.75

Caponizing Sets $\ldots \ldots \ldots \ldots \ldots \ldots \ldots$

Poultry Killing Knife...............

\section{Incubator Lamps}

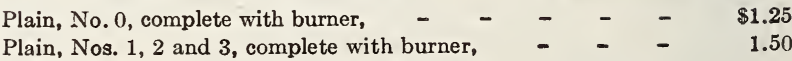

\section{Incubator Burners}




\section{GALVANIZED POULTRY NETTING}

WE HANDLE THE BEST MAKE OF NETTING

STOCK WIDTHS-2 inch Mesh.

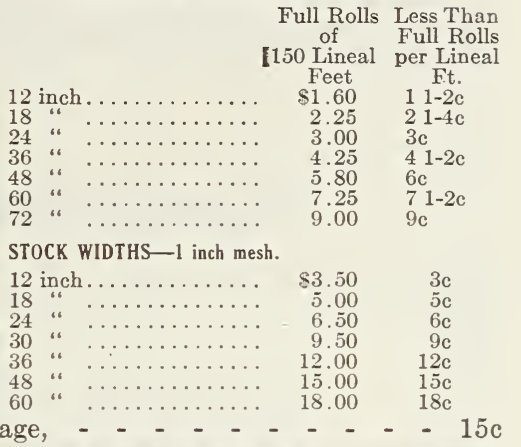

POULTRY NETTING STAPLES.-Per lb. package,

\section{AMERICAN FIELD FENCING}

The best fencing made for stock of any kind. It is strong, neat and safe; will stop anything from a pig to a buffalo.

Made in widths from $221 / 2$ inches to 58 inches. Stock numbers are 845-12, 635-12, and 832-6.

Stock numbers on Poultry and Garden fence are 2158-6.

\section{AMERICAN PARK and PADDOCK FENCE}

Made in six designs, the highest $\delta 8$ inches, the lowest 61 inches. Prices on Application.

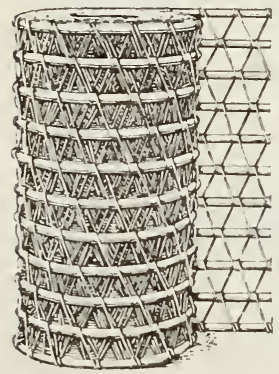

\section{DIAMOND LAWN FENCE}

This is especially designed for Lawns and Yards. Is 2 in. mesh, making it hard to climb, is very strong and neat, can be used with our steel posts or on wood posts; made in various heights. Prices on application.

Send for our Special Fence Book, which will tell you all about the American fences and the Yankee Gates.

See inside back cover for other Lawn Fence.

\section{FARIMERS' FAVORITE FEED COOKER}

For Butchers, Sugarmakers, Poultrymen and Dairymen. The Boiler is made of Galvanized Steel. The price is for cooker complete, consisting of stove or fire box, galvanized boiler with cover, one length 6 in. pipe and damper and 6 in. elbow.
No. 1-Capacity 25 gallons, - - - $\$ 18.00$
No.4_ “ 50 "
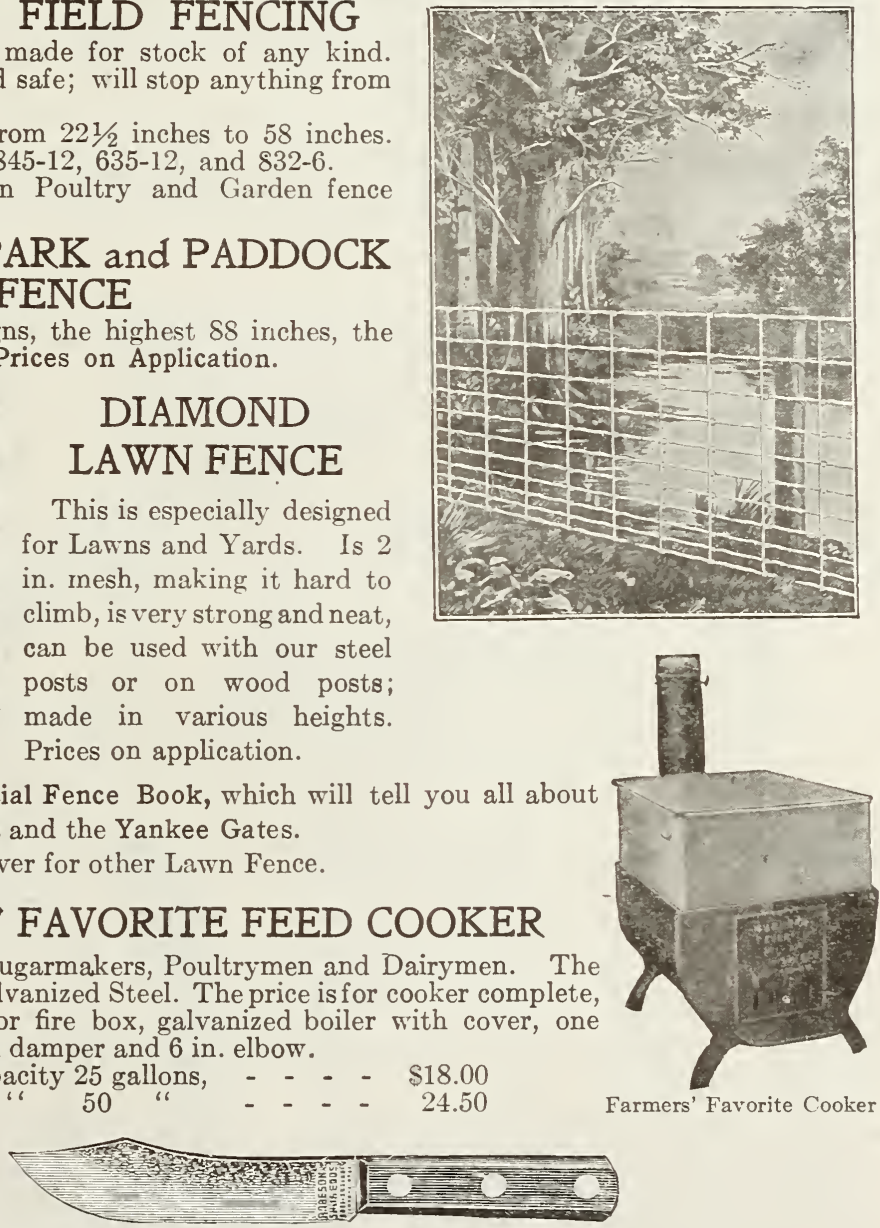

BUTCHER \}Inches- $5,51 / 2,6,7,8, \quad 9, \quad 10,12, \quad 14$,

KNIVES $\}$ Prices-35c, 45c, 50c, 60 c, 65c, 75c, $\$ 1.00, \$ 1.25, \$ 1.50, \$ 1.75$ and $\$ 2.00$. STICKING KNIVES-Warranted, 5 in. $40 \mathrm{c} ; 6$ in., $50 \mathrm{c}$.

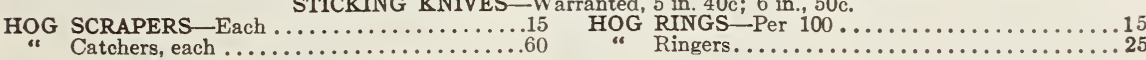




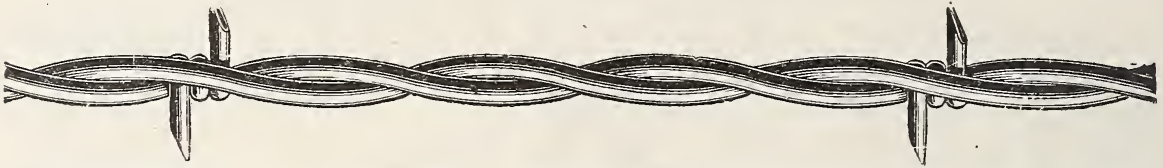

The above is cut of 2 point Barb-Wire. This is the style of barb-wire now in general use. Comes on reels of 80 Rods each.

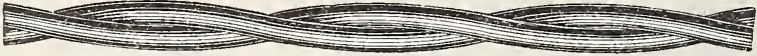

PLAIN 2-PLY FENCE WIRE-This is safer than the Barb-wire for horse pasture. If the end posts are firmly set so that they do not give it will never sag. We are always in a position to name you Low Prices on first class steel fence wire.

\section{FLOWERING BULBS IN THEIR SEASON}

LILIES, TULIPS, NARCISSUS, FREESIAS, HYACINTHS, CROCUS, JONQUILS, ETC.

We import direct from Holland. They are fine, strong bulbs

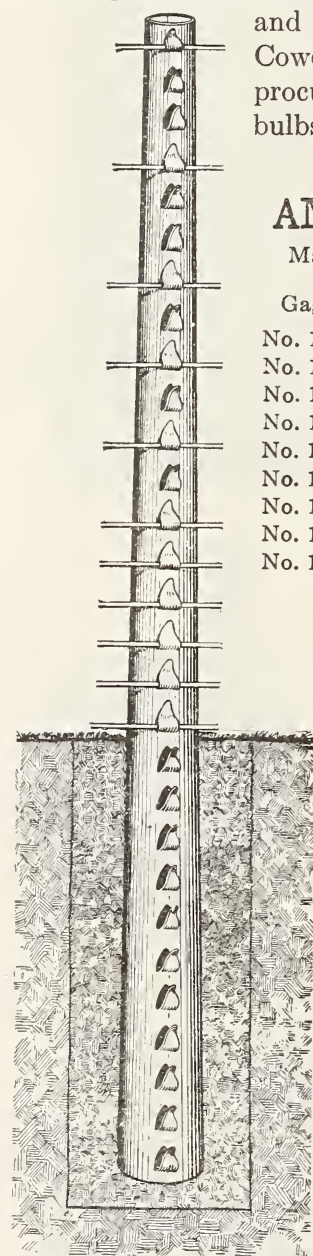
and will produce good bloom. We carry Cowee's Gladioli bulbs in their season. We procure for you at short notice any flowering bulbs wanted.

\section{AMERICAN FENCE POSTS}

Made of steel, galvanized, almost indestructible Length Approximate Prices

Gage and Design in Feet Weight in lbs. Per Post

No. 16 Line Post...... 61/2 $7 . \quad .55$

No. 16 Line Post...... 7

No. 16 Line Post..... $71 \frac{1}{2}$

7.75

.55

No. 16 Line Post ...... 8

8.5

8.5

No. 10 End Post...... 7

51

.67

No. 10 End Post...... 8

To. 10 Corner Post ... 7

No. 10 Corner Post ... 8

No. 10 Hitching Post . $61 / 2$

75

1.

3.88

75

4.37

86.

5.75

28

6.19

2.50

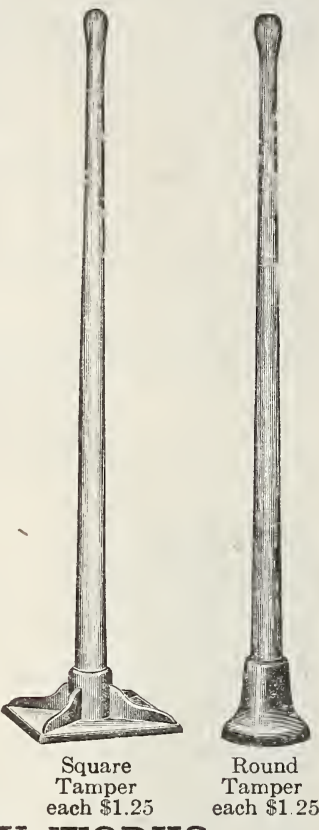

\section{ANCHOR POST IRON WORKS}

Prices on Anchor Posts and Fence either for material only or for Fence Erected on application.

GIBBS Post Hole Digger.

The Best General Purpose Digger Made. Price $\$ 2.50$. Wire Fence Staples per lb., 10c.

CAST IRON MAULS.Weight from 12 lbs. to $20 \mathrm{lbs}$, each......\$1.50 CAPS FOR DRIVING POSTS, I5c American Fence Stretcher, "COME ALONG"-Wire

Stretcher Price 60c ROPE AND PULLEY STRETCHERS, \$1.25 LINEMAN'S PLIERS, POST HOLE SPOONS, POST AUGER, $\quad \$ 3.75$ WIRE CUTTING PLIERS,

Medium size, $\quad 75 \mathrm{c}$ Large size, $\$ 1.00$ FENCE CUTTING PLI-

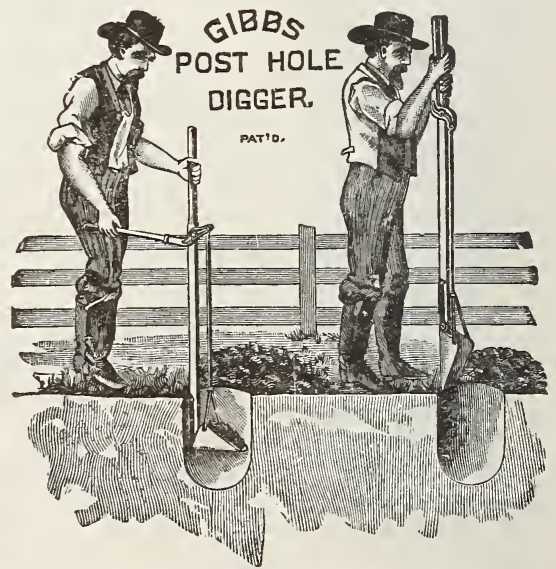


FRANK HOWARD, PITTSFIELD, MASS.

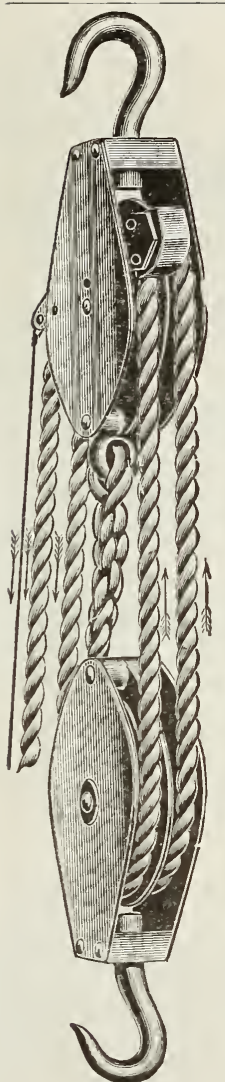

RAZORS

\section{Patent Automatic Lock Tackle Block} THIS LOCK HOLDS THE LOAD AT ANY POINT

warranted knives.

$\begin{array}{ll}\text { No. } 8 & \begin{array}{c}\text { Sheaves. } \\ 2 \text { and } 1\end{array} \\ \text { No. } 9 & 2 \text { and } 1 \\ \text { No. } 10 & 2 \text { and } 2 \\ \text { No. } 11 & 3 \text { and } 2 \\ \text { No. } 12 & 3 \text { and } 3 \\ \text { No. } 13 & 4 \text { and } 3 \\ \text { No. } 14 & 2 \text { and } 1 \\ \text { No. } 15 & 2 \text { and } 2 \\ \text { No. } 16 & 3 \text { and } 2 \\ \text { No. } 17 & 3 \text { and } 2 \\ \text { No. } 18 & 4 \text { and } 3\end{array}$

Size Lbs. one man Lbs. List

$\begin{array}{cccc}\text { Rope } & \text { can hoist. Capacity. Price. } \\ 3-8 & 300 & 600 & \$ 3.00\end{array}$

$\begin{array}{llll}5-8 & 350 & 1000 & 5.50 \\ 5-8 & 500 & 1500 & 6.00\end{array}$

6.00

$\begin{array}{llll}5-8 & 750 & 3000 & 7.60\end{array}$

$\begin{array}{llll}5-8 & 900 & 3500 & 8.35\end{array}$

$\begin{array}{llll}3-4 & 350 & 1250 & 6.50\end{array}$

$3-4 \quad 500 \quad 1800 \quad 7.00$

$\begin{array}{lll}3-4 & 625 & 2500\end{array}$

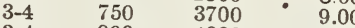

$4000 \quad 10.00$

APPLE PARERS-Hudson . ............ $\$ 1.50$

REVOLVERS ......................... $\$ 1.50$

CORK SCREWS ...................... to $\$ 1.00$ CORN POPPERS........1 qt. $25 \mathrm{c}, 2$ qt. $30 \mathrm{c}, 4$ qt. 60

TABLE KNIVES AND FORKS

Nice assortment, ranging in price from $\$ 1.50$ to $\$ 3.50$ per set.
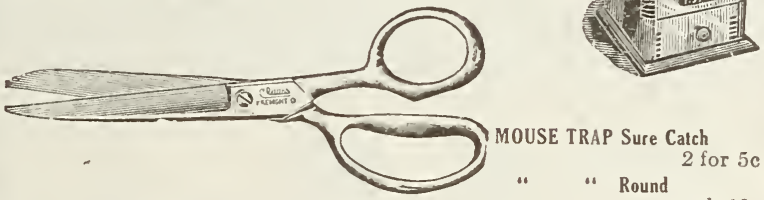

SCISSORS AND SHEARS-Our "Special"

Scissors arc "best goods"-we have a full line of these, also chcaper grades 5

5
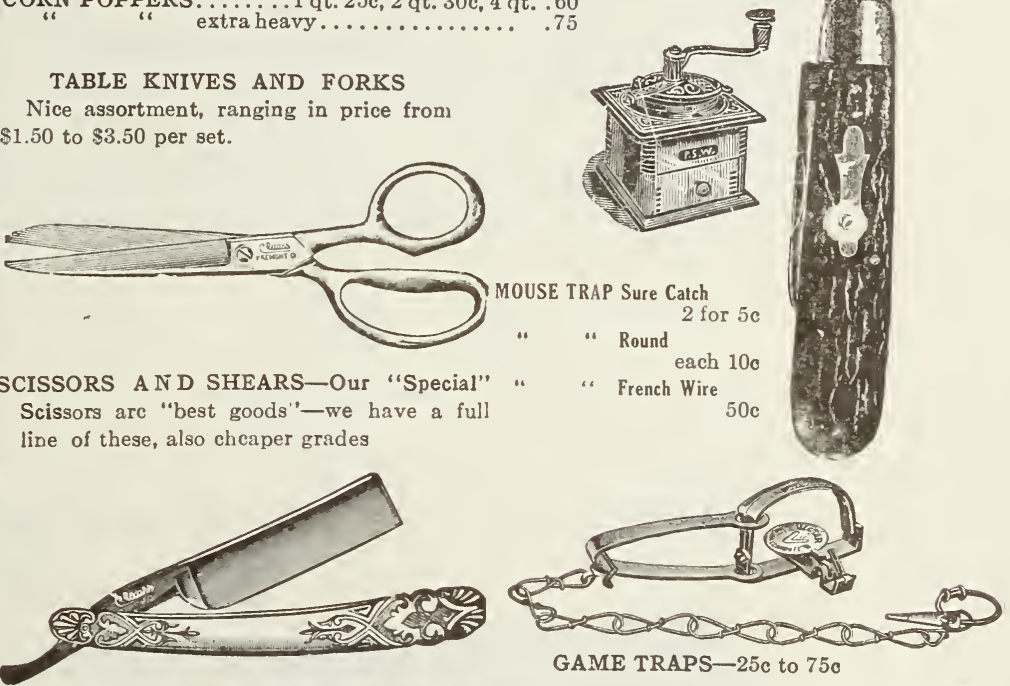

Our Special Brand of Razors are beauties and are splendid cutters. Prices from $\$ 1.50$ to $\$ 3.00$.

GILLETTE RAZOR-(6 extra blades) $\$ 5.00$ and upwards GEM JUNIOR RAZOR-\$1.00. STAR SAFETY RAZOR$\$ 1.50$ and upwards SEXTOBLADE SAFETY RAZOREVER READY SAFETY - $\$ 1.00$ RAZOR STROPS-Swing from $75 \mathrm{c}-\$ 2.25$ COMBINATION $-35 \mathrm{c}$ to $\$ 2.50$.

LATHER BRUSHES-25c, $5 \mathrm{C}_{\mathrm{c}} \mathrm{c} 6 \mathrm{c}$, $\$ 1.00$ and $\$ 1.50$.

SHAVING MUGS-25c, 35̃ and $40 \mathrm{c}$ RAZOR HONE- $\$ 1.00$ and $\$ 1.25$. KITCHEN KNIVES-10c, 15c, 20c, 25c

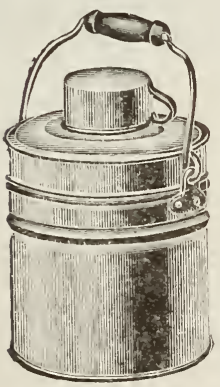
and $35 \mathrm{c}$ DINNER PAILS Common, DINNER PAILSand $\$ 1.25$. LUNCH BOXES-Tin $35 \mathrm{c}$ LUNCH BOXES-folding 30 c THERMOS LUNCH KITS $-\$ 1.00$ to $\$ 4.50$. THERMOS BOTTLES$\$ 2.50$ to $\$ 6.00$ Thermos Bottle Fillers, $\$ 2.00$

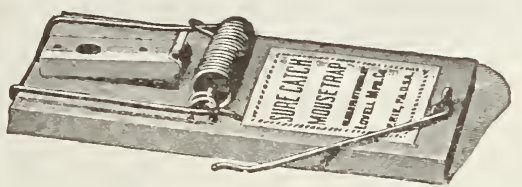

RAT TRAP

Sure Catch $10 \mathrm{c}, 15 \mathrm{c}$ RAT TRAP

French Wire 850

TACK PULLS- 10

CUTTLE BONE-Each-

BIRD GRAVEL-Per Pkt., 10c Zc to 50 WER POT BRACKETS-Single Pot Bracket,
Two Pot Bracket, one arm, Two Pot Bracket, two arms,

CARVING SETS-An assortment of warranted sets, prices from

COUNTER DUSTERS-

WELL BUCKETS-Oak, galvanized hoop.

WELL BUCKETS-Galvanized.

FLOUR SIEVES-

HAMMOCK HOOKS-Per pair,

BAIL AND BOX HOOKS-Each,

BIRD CAGE HOOKS$50 \mathrm{c}$ and $65 \mathrm{c}$ $\$ 2.00$ $20 \mathrm{c}, 25 \mathrm{c}$ and $30 \mathrm{c}$

150 $45 \mathrm{c}$ and $50 \mathrm{c}$ $10 \mathrm{c}$ and $15 \mathrm{c}$

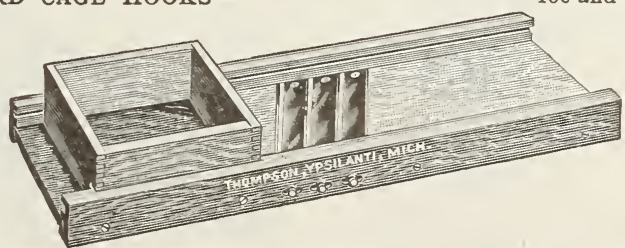

KRAUT or SLAW CUTTERS-(2 knives)

$65 \mathrm{c}$ and $\$ 1.50$ $\$ 2.50$ and $\$ 3.50$ $\$ 2.50$ and $\$ 6.50$

TACKS-Gimp, Carpet and Double Pointed, per pkt., 10c and 15c. 


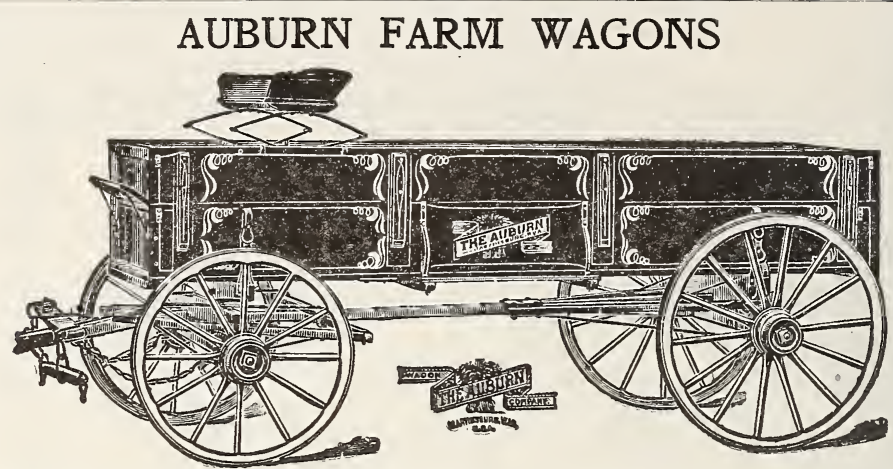

The Lightest Running and Strongest Farm Wagons on Wheels THOROUGHLY MADE THROUGHOUT, WELL FINISHED, FULLY GUARANTEED BROAD TIRES.

Designation. Style. Size of Axle. Kind of Wheels Size of Price Gear Price Complete With Box. and Seat. Standard Solid Axle, $\quad 13 / 4 \mathrm{in}$. Sarven $\quad 3 \times 1 / 2$ in $\quad \$ 138.10 \quad \$ \$ 173.00$ Heavy " " 20 " " $"$ " "

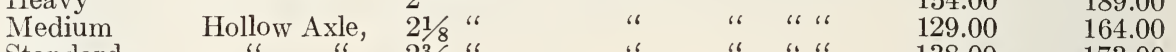

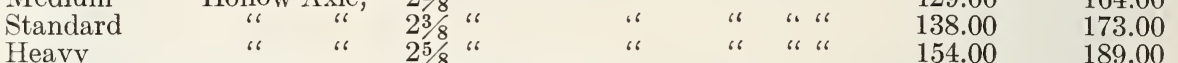
Heavy Double Box, Complete with Spring Seat, $\$ 40.00$.

Farmers' Farm Truck, gear only Thimble Skeins, 3 inch Tire, Wheels, 30 in. and 36 in., weight $497 \mathrm{lbs}$. $\$ 85.00$

\section{AUBURN ONE HORSE WAGONS}

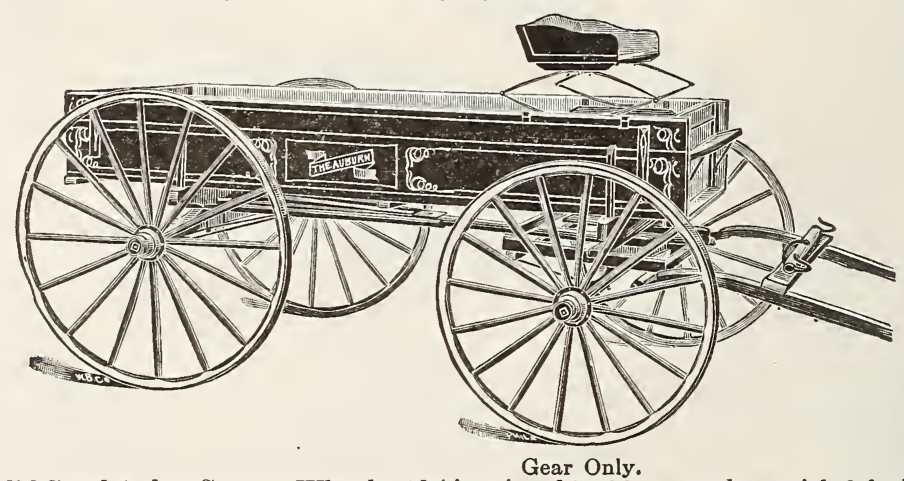

$11 / 4 \mathrm{in}$. Solid Steel Axles, Sarven Wheels, $13 / 4$ in. tire, $\$ 64.00$, complete with $9 \mathrm{ft}$. box $\$ 86.00$ $13 \frac{3}{8}$ in. " " " 2 " " 75.00 , " " $9 \mathrm{ft.} \mathrm{"} 98.00$ Double Box, Complete with Spring Seat, $\$ 29.00$.

\section{STEEL WHEEL FARII TRUCK}

A Low Down handy wagon for farm use. Wheels 28 in. and 32 in., Tires 4 in Price without box,

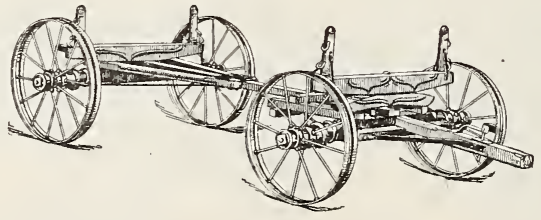




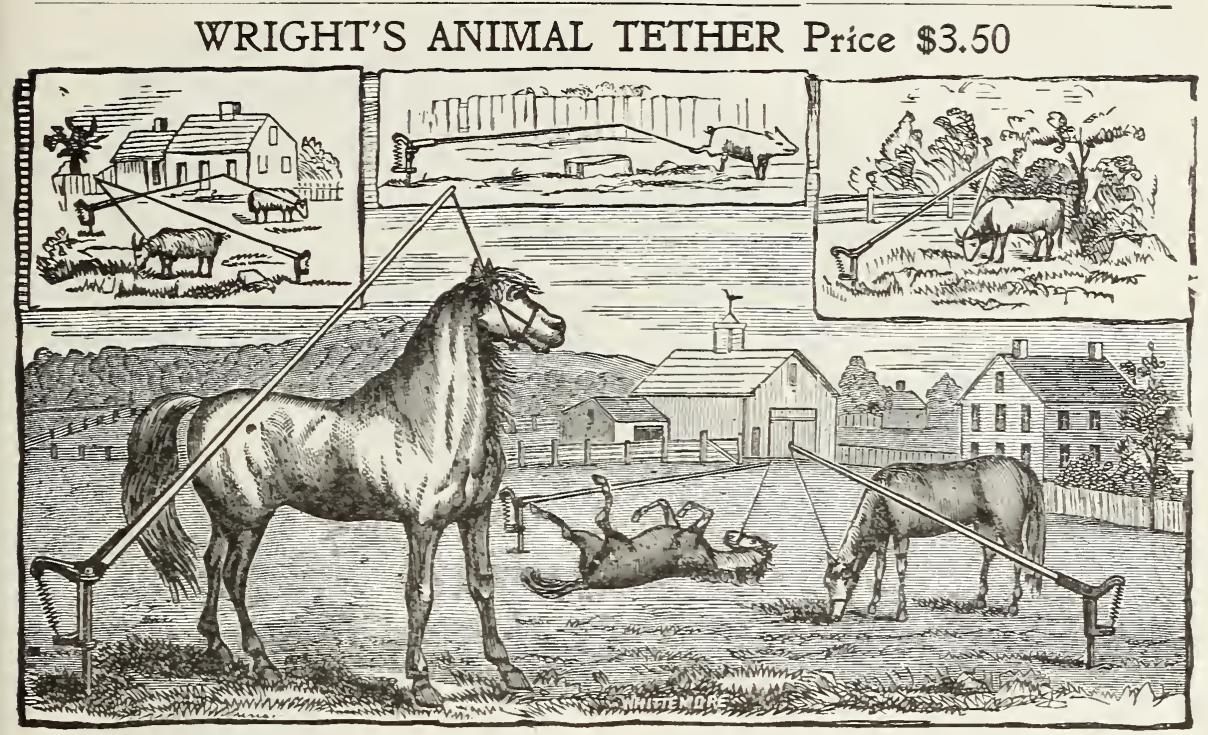

\section{Stewart \\ Power Horse Clippers, $\$ 8.75$}

Bottom Plate for Power Clipper, $\$ 1.50$ Top Clipper Head Complete $\$ 3.50$ Horse Blankets

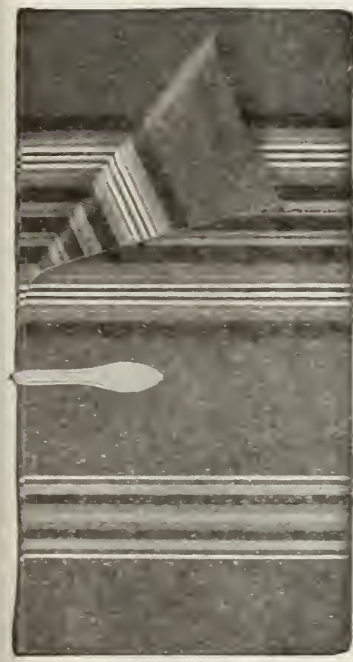

We purchase our STREET and STABLE BLANKETS, Automobile Shawls and Robes from two very large blanket mills. $\mathrm{We}$ show a nice assortment and our prices are right.

HORSE CLIPPERS

From........\$1.75 to $\$ 2.50$

BODY OR BRISTIE HORSE BRTSHES

FEED BAGS.................. $\$ 1.00$ to $\$ 1.50$ SLOW FEED .......................... 1.50 Hitch Rings, $20 \mathrm{c}$ and $25 \mathrm{c}$ Hitch $W$ eights, per lb. $71 / 2 \mathrm{c}$
A Splendid Machine

For Little Money

We grind plates for power machine at $75 \mathrm{c}$ to $\$ 1.00$ per set.

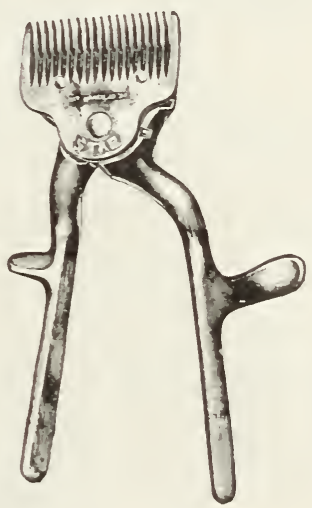

(Toilet Clippers) TOILET CLIPPERS From....... $\$ 1.25$ to $\$ 3.00$ Fetlock Clippers, $\$ 1.50$

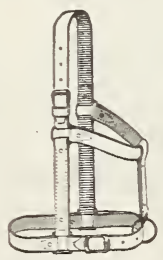

\section{HALTERS}

WAGON SHOES $\$ 2.00$ Each. HAMOIS fine large, $\$ 1.00, \$ 1.25$ and

HALTERS (Horse) Leather $\$ 1.50 \$ 1.75, \$ 2.00$ and $\$ 2.25$

HALTERS (Calf) $\$ 1.25$ HALTERS (Cow) $\$ 1.75$ WHITE SAND, Per Quart 5c...... Per Bag $\$ 1.00$ FETLOCK SHEARS,................ 1.25 


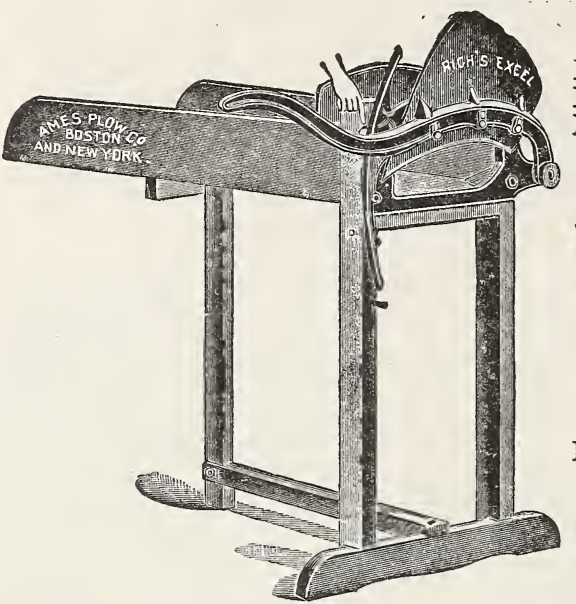

WAGON JACKS

BOSTON.-No. 1, (leather protection) ......\$4.40 No. 2, " " "

No. 3, " " $\quad \ldots \ldots .66 .00$

\section{LITTLE GIANT}

\begin{tabular}{l|l} 
No. $0 \ldots \ldots \ldots \ldots . \$ 2.25$ & No. 2...........\$3.00
\end{tabular}

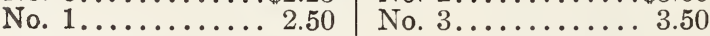

ROPE TIES.-Jute, 1 Snap..............20

" " " $\quad$ " 2 Snap and Ring $\ldots \ldots \ldots \ldots \ldots 40$

\section{RIVETING IVACHINE}

Price each ........................60

"Rivets for Acme machine, per box ........... 10

\section{LEVER FEED CUTTER}

.$\$ 8.75$

.11 .75

CORNER HAY RACK, $\$ 2.50$

HOG TROUGH,-Cast Iron $4 \mathrm{ft}$. long, $\$ 7.00$

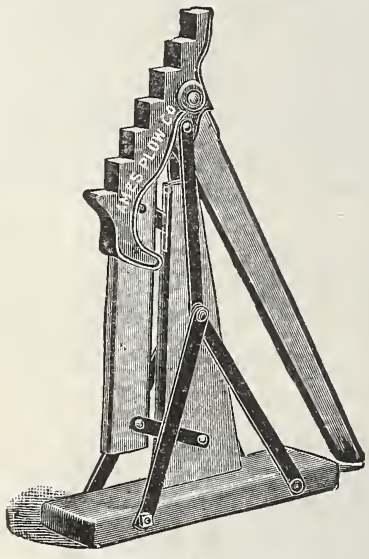

LITTLE GIANT JACK
BROOM-Rattan Push, .................10 1.10

“ Steel Push.................... Extra $\$ 1.00$

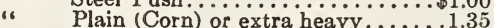

Rattan Mixed

BELLS-Team, Medium.......25c and $30 \mathrm{c}$ beavy..............60 $85 \mathrm{c}$ and $\$ 1.00$ Nice assortment Chime Bells for light Driving. COPPER RIVETS. $-1 / 2, \frac{1}{8}$ and $\frac{3}{2}$ in. per pkt. 25c "Slotted assortment.....10

OAT SIEVES - .................. \$1.00 AXLE WASHERS - ..............Per coil, 15c LANTERNS - (Dietz) Lift wire No. $0,75 \mathrm{c} ;$ No. $1,95 \mathrm{c}$.

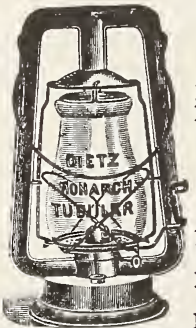

LANTERNS - (Dietz) Buckeye “ Dash ....\$1.50 “ Cold Blast, 1.25 “ Delight, .. 1.25 EUREKA DRIVING LAMP, $\cdots 1.85$ LANTERNS-Union Driving

$$
\begin{aligned}
& \text { Lamp ..5.00 } \\
& \text { Barn Lamps, } \\
& 2.00 \text { and } 3.50
\end{aligned}
$$
، Dietz Jr. DrivLANTERN GLOBES- No. 0. $15 \mathrm{c}^{\circ}$ No. $1,20 \mathrm{c} ;$ red, $50 \mathrm{c}$. LANTERN BURNERS,

150 and $20 \mathrm{c}$

WHIPS-Nice assortment of Team and straight Whips and Lashes.

PAILS-J. I. C. (Oak Stable)...........\$1.50

"White pine stable.............. 85

“ Fibre, stable................... 1.50

"“ " house...................... pail, $50 \mathrm{c}$, and $\$ 1.50 ; 15 \mathrm{lb}$. pail, $\$ 2.25$; Snow Flake, $40 \mathrm{c}$ and 650
AXLE OIL.-Pints, 40c; Quarts, 650 NEAT'S FOOT OIL.-Pints, 45c; Quarts, $75 \mathrm{c}$. HARNESS DRESSING,-(Frank Miller's), Quart 60c; Pints, $40 \mathrm{c}$.

HARNESS OIL.-Frank Miller's. Pints, 45c; quarts, $75 \mathrm{c}$.

HARNESS SOAP-Frank Miller's pan 40c and 70c HARNESS SOAP-Tub, $\$ 1.50$

MOWING MACHINE OIL.-Bulk, per Gallon, 60c In Quart Cans, 30c; in Gallon Cans, 85c SEPARATOR OIL.- "Howard's Best," per Gallon, $\$ 1.00$; per quart, $40 \mathrm{c}$

GAS ENGINE OIL.-Gallon can, $\$ 1.00$.

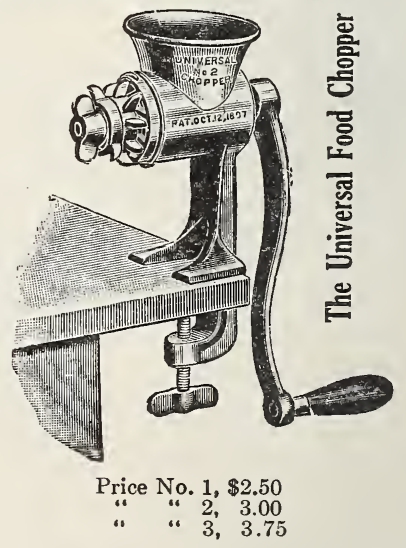




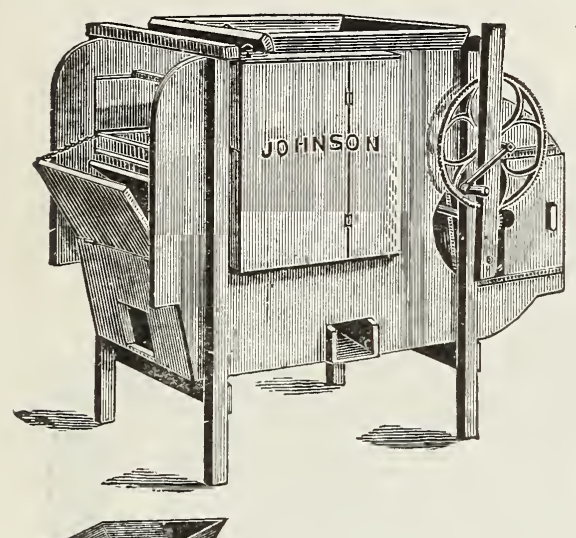

THE CHICOPEE FAN MILL The Popular Fan of New England

PRICE - . - . . - $\$ 32.00$

\section{BANNER ROOT CUTTER}

\section{A RAPID SLICER.}

No 20, Hand Machine, - - - - $\$ 11.00$

" 30 , " " " - - - 19.00

“ 31, All Steel and Iron - - - 16.00

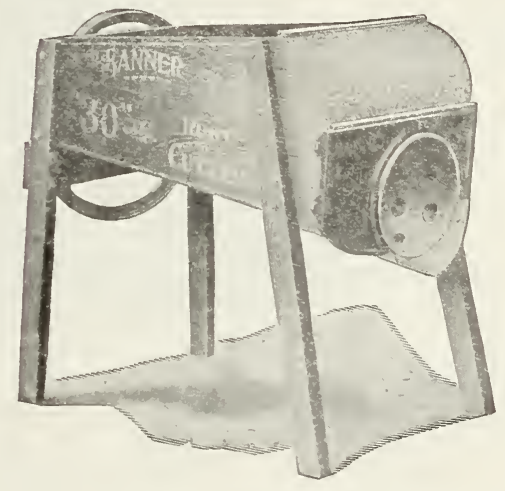

LARD AND WINE PRESSES No. $11 \$ 8.50$.

\section{CIDER MIILS}

$\left.\begin{array}{l}\text { Junior Farmers Favorite } \\ 2 \text { Curbs, Weight } 387 \text { lbs. }\end{array}\right\} \$ 30.00$.

Junior No. 1 Farmers Favorite

2 Curbs, Weight 208 lbs. $\} \$ 20.00$

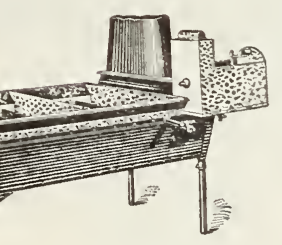

MAPLE SUGAR

EVAPORATORS

AND SUPPLIES

Write for prices.

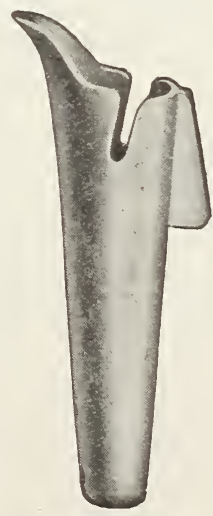

Sap Spout

Rubbish or Paper Burner $1-12 \times 18$ in., $\$ 1.75$ $2-15 \times 22$ " 2.50 3 - $18 \times 26$ “. 2.75 $4-21 \times 31$ “ 3.50 SYRUP CANS.-One gal., square,
screw top each $24 \mathrm{c}$; per $100, \$ 22.00$

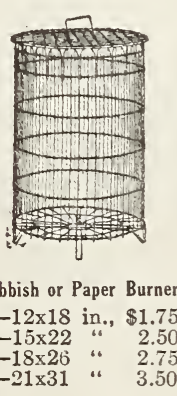




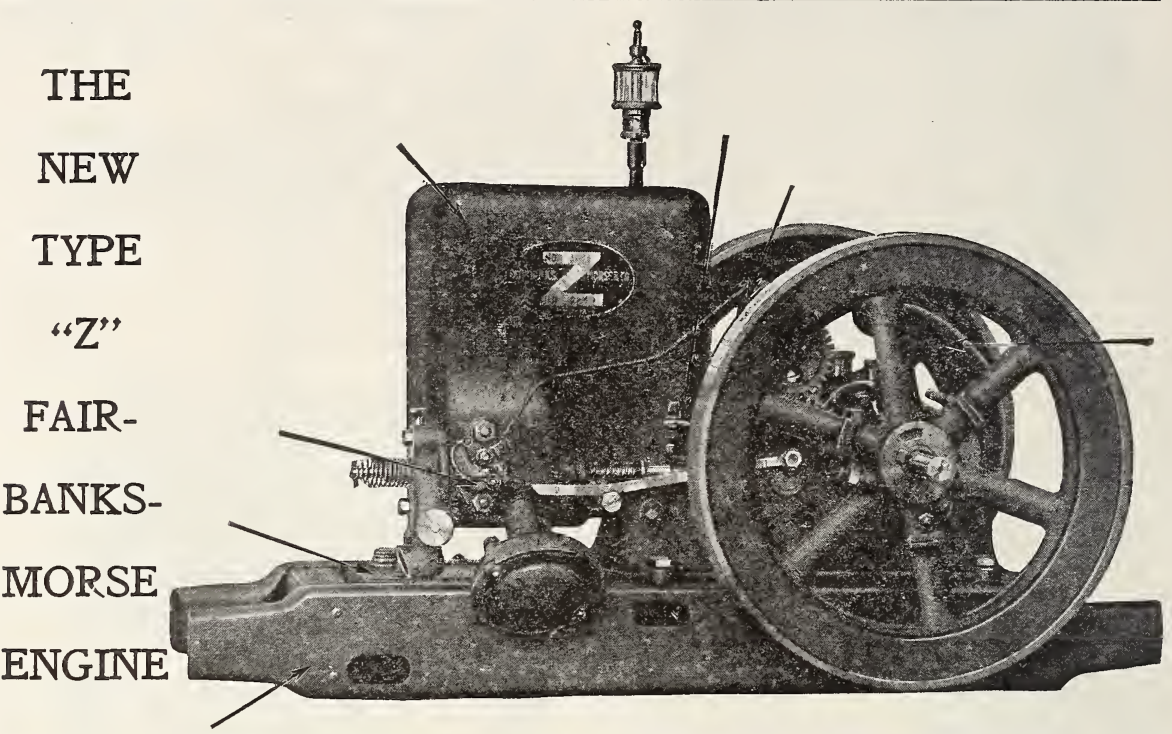

Economical, Simple, Substantial, Gun Barrel Cylinder Bore.-Complete with Built-in

Magneto, more than rated power. Sizes are $1 \frac{1}{2}$ H. P., 3 H. P., 6 H. P., 10 H. P. and $15 \mathrm{H}$. P. Prices on application.

\section{TYPE "H" QUICK START KEROSENE ENGINES}

Made in 1-2-4 and 6 Horse Power. Write or see us for special catalog.

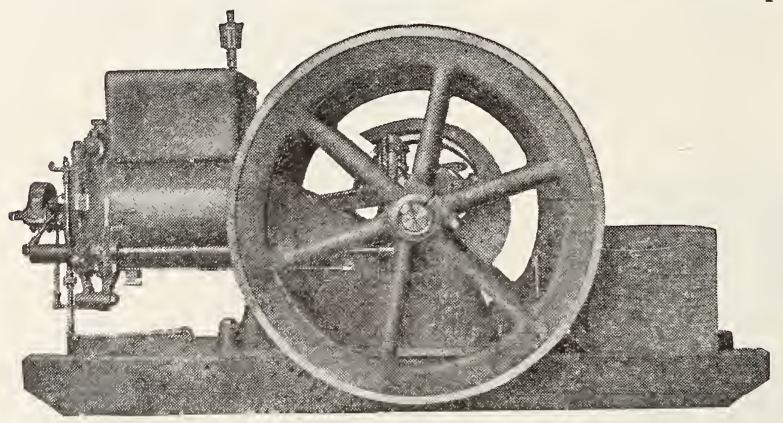

\section{JACOBSON GAS- OLINE ENGINES}

Built upon Honor by Engine Builders. You cannot go wrong in buying a Jacobson. Made in various styles and sizes for Gasolene or Kerosene. Beginning with the Junior Sturdy Jack (Gasolene). $11 / 2 \mathrm{H}$. P. and from this up to almost any horse power required. Don't buy power without seeing us.

Special Electric Engine and Electric Lighting Outfit. For residences or farm lighting, or for small store, garage or manufacturing establishment. If in need of a lighting plant or power we will be glad to send an expert to confer with you.

\section{WOOD FRAIIE SAWING MACHINE}

Made of Hard Wood, will accommodate saws from 20 in. to 30 in. in diameter. Pulley is 5 inches in diameter with 6 inch crown face, Balance wheel weighs $95 \mathrm{lbs}$. The frame can be fitted with pole extension if specially ordered, at extra cost. We recommend using 4 in. 4 ply rubber belting, 10 foot centers, 22 feet belt.

Tilting Table Complete with 22 in. Saw, $\$ 40.00$

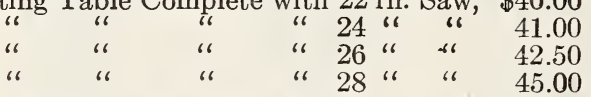

For Sliding Table add $\$ 6,00$. For Pole Saw add $\$ 6.00$.

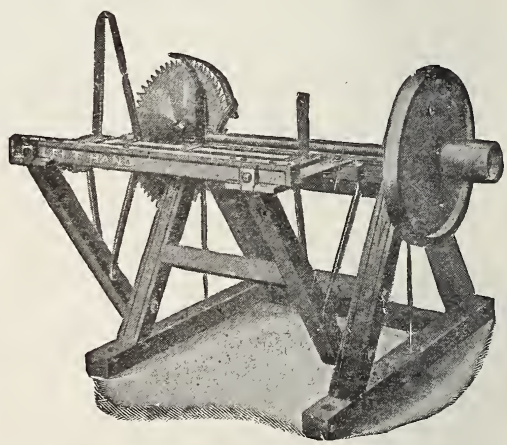




\section{BLIZZARD ENSILAGE CUTTER AND BLOWER}

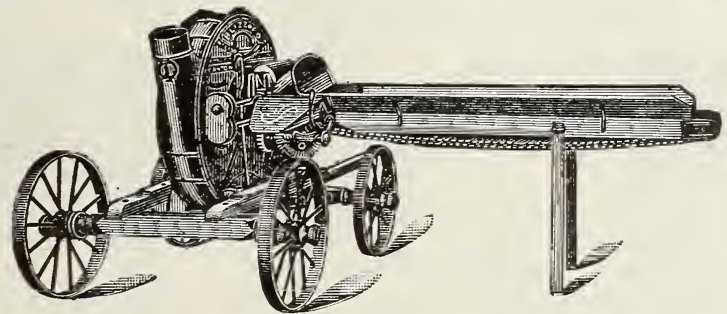

All the very latest improvements are embodied in this machine. They are built for endurance and to give satisfaction to the user. The construction is such that they are operated probably with as little power size for size as any cutter and blower made. One of the popular sizes for ordinary farm work is No. M. 21 requiring from 4 to 7 Horse Power, and the No. M. 13 requiring 7 to 10 Horse Power. Write for special cutter catalog.

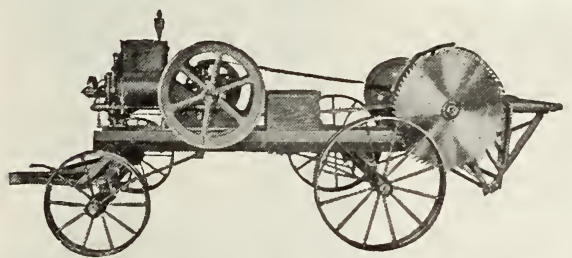

\section{ENGINE AND WOOD SAWING OUTFIT}

Prices on application

Especially adapted for farm use, Practical, Durable, Economical.

No. 1, with extra set grinding plates, $\$ 35.00$

No. 2, with extra set grinding plates, $\$ 45.00$.

Elevator and Bagger, $5 \mathrm{ft}$., extra, $\$ 16.00$.

Hand and Power Grinder No. 20 with stand, $\$ 22.50$. No. 15, Hand and Power, \$16.00. H a nd Grinder, \#10 without stand, $\$ 10.00$.

LENTZ GRINDING

MILL - Our excellent Farm Mill. Price $\$ 65.00$ and $\$ 75.00$.

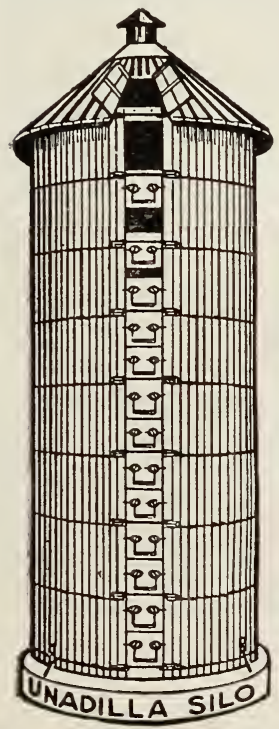

\section{FAIRBANKS' MORSE FEED MILLS}

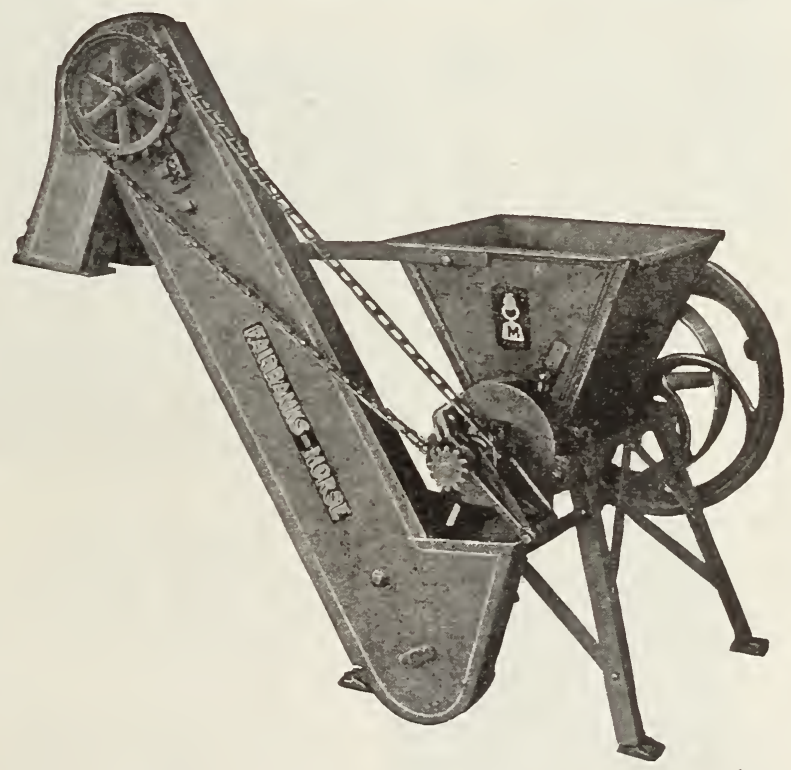

\section{THE UNADILLA SILOS}

The use of the silo on the dairy farm has long since passed the experimental stage and is now considered a fixed necessity. We are offering you a SILO THAT IS UP TO DATE IN EVERY DETAIL OF MODERN SLO CONSTRUCTION, in sizes holding from 15 to 393 tons. They are made in White Pine, Oregon Fir, and Spruce. We want to figure with you on a Silo. Write or see us. 

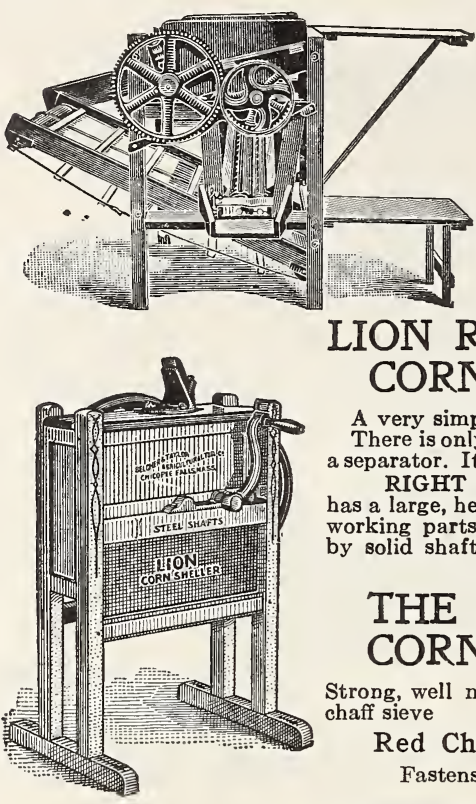

\section{The Chicopee Corn Husker}

A Corn Husker that leaves the stalks in shape to bind, something the farmer has been looking for Power required for full capacity 5 to $6 \mathrm{H}$. P. - and will husk from 25 to 50 bushels per hour. Some of these machines are running with $21 / 2$ horse power engine, with this power they husk from 15 to 25 bushels of corn per hour. "The Chicopee" is guaranteed to husk the corn and separate the ears from the stalks without material injury to the grains ? corn. Price,

4 Roll $\$ 120.00$

6 " $\$ 140.00$

\section{LION RIGHT HAND CORN SHELLER}

A very simple and popular Sheller.

There is only one size and that is with a separator. It is a

RIGHT HAND SHELLER

has a large, heavy balance wheel. The working parts are held firmly together by solid shaft boxes or bearings.

PRICE, $\$ 13.00$

\section{THE CHICOPEE CORN SHELLER}

Strong, well made, with separator and chaff sieve - $\quad \$ 10.5$ ).

\section{Red Chief Corn Sheller}

Fastens to Barrel, $\$ 2.50$

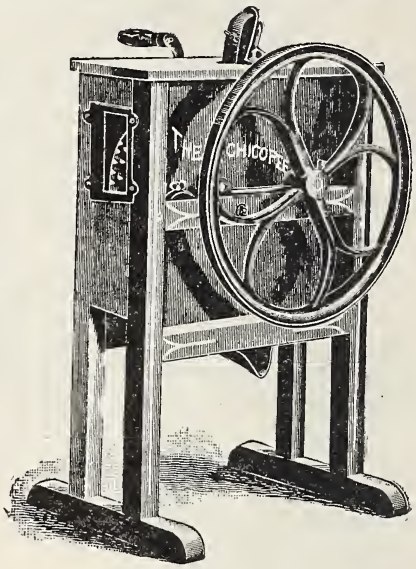

\section{STEEL DRY IMEASURE}

2 qt. $45 \mathrm{c}, 4$ qt. $75 \mathrm{c}$,

8 qt. $90 \mathrm{c}, 16$ qt. $\$ 1.25$.

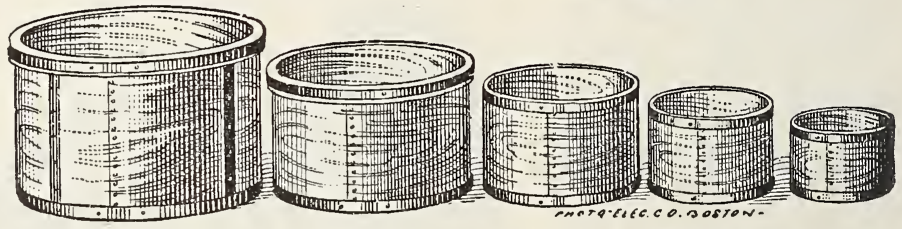

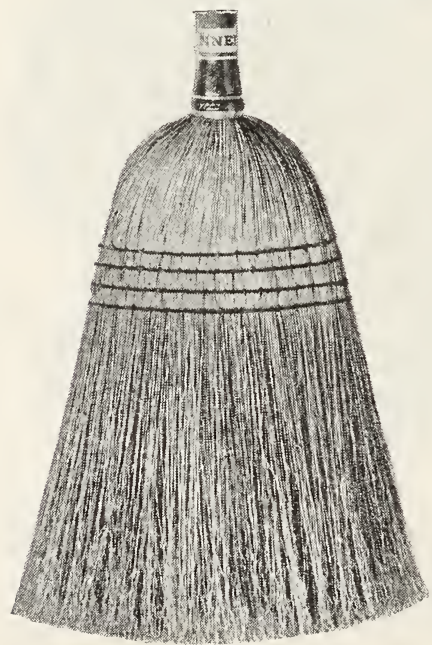

\section{Brooms}

No. 6-House (fine) $\$ 100$ "7- " "\$1.15 Whisk Brooms,

$25 \mathrm{c}, 30 \mathrm{c}$ and $35 \mathrm{c}$ Barn Brooms, see pg. 82

\section{OAK DRY MEASURES}

Sealed, 1 qt. $25 \mathrm{c}, 2$ qt. $35 \mathrm{c}$, 4 qt. $70 \mathrm{c}, 8$ qt. $90 \mathrm{c}, 16$ qt. $\$ 1.75$, per set $\$ 2.85$.

\section{SEAMLESS GRAIN BAGS}

Per bale, 100 bags. Prices on application.

\section{BAG HOLDERS}

Metal Tunnel-Adjustable to desired height, very convenient, Price, $\$ 3.50$.

$\begin{array}{lc}\text { BOSTON Sizes } \\ \text { PATTERN } & 0 \\ \text { TRUCKS } & 1 \\ 2 \\ 3 \\ 4\end{array}$

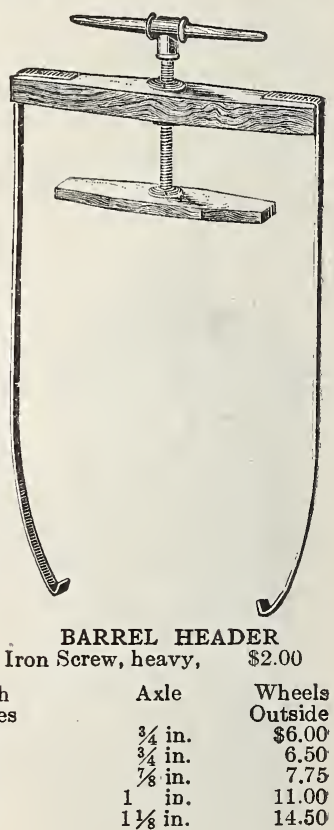




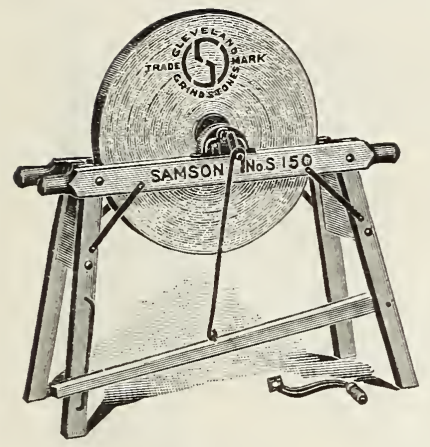

\section{MOUNTED GRINDSTONES}

$\begin{aligned} \text { Weight about } & \text { Price. } \\ \text { Extra Wood Frame..............130 lbs. } & \$ 8.50\end{aligned}$

Regular “ " ................100 lbs. 7.50

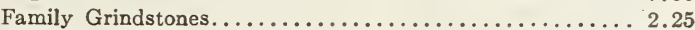

Huron.................................... per $1 b .50$

Grindstone Fixtures, per set heavy...............\$1.75

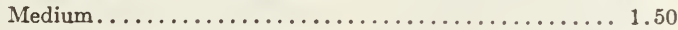

Royal Sickle and Tool Grinder................... 7.50

\section{SCREEN DOORS}

Plain, 3 inch stile, wire black, price complete with trimmings, $\$ 2.25$ Light Finish, Fancy Pattern، 4 in. stile.......\$3.00 and $\$ 3.50$ Our Custom Made.........................\$55.00

\section{WINDOW SCREENS}

The "Leader," Hardwood Finish, Height 18 in. Adjusts 20 in to 33 in. $60 \mathrm{c}$ “ “ “ Sherwood Steel, 18 inch, 22 in. to 33 in. - - - $-\quad-\quad-80 \mathrm{c}$

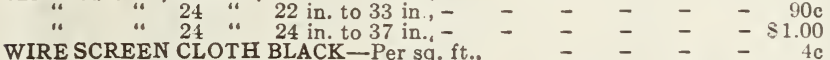
BRONZE SCREEN CLOTH- Per sq. ft. - - - $-\quad-\quad 4 \mathrm{c}$
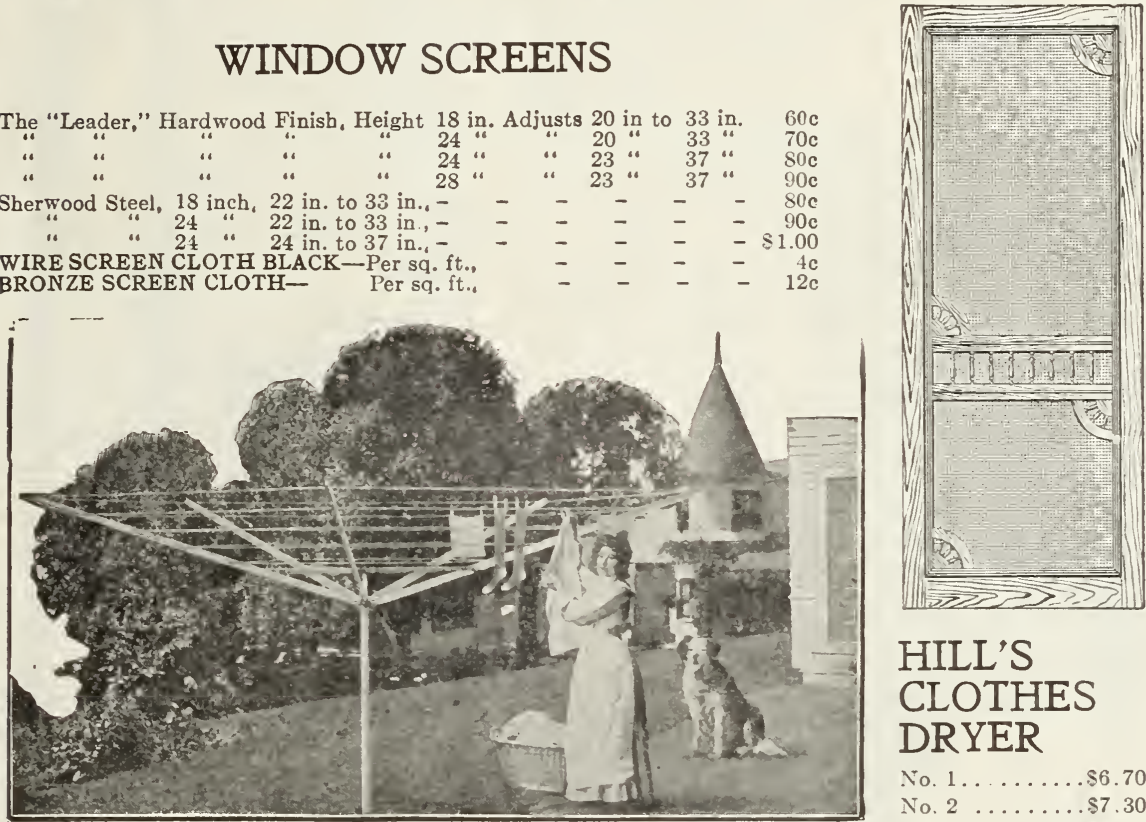

HILL'S

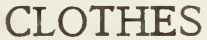
DRYER

No. $1 \ldots \ldots \ldots \$ 6.70$

No. $2 \ldots \ldots . \$ 7.30$

No. $3 \ldots \ldots . \$ 8.50$

REVOLVING CLOTHES DRYER

Very convenient, easily folded, can be removed from stand, and placed under cover if desired. Price 110 ft., \$5.50; $150 \mathrm{ft} ., \$ 6.00$.

\section{CLOTHESLINE POSTS}

(Steel Galvanized)، $10 \mathrm{ft.。}$

\section{ADJUSTABLE SCAFFOLDING JACKS}
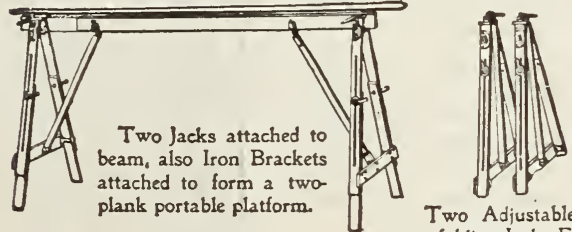

Two Adjustable Scaffolding Jacks Folded.

Practical for all interior scaffolding, mill work, metal ceiling, plastering, decorating, etc.

Light, Rigid and Quickly Adjusted.

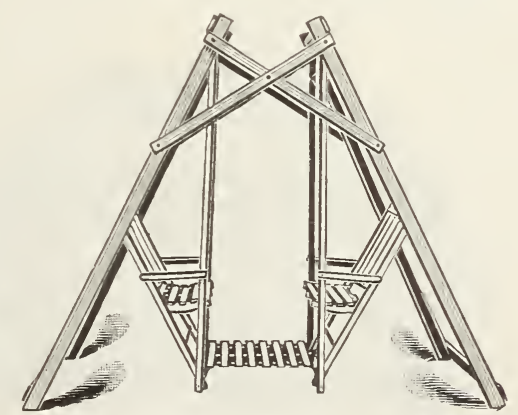

LAWN SWING.-Heavy wood frame, two passenger ، $\$ \$ .00$ ، four passenger, $\$ 12.00$. 
FRANK HOWARD, PITTSFIELD, MASS.

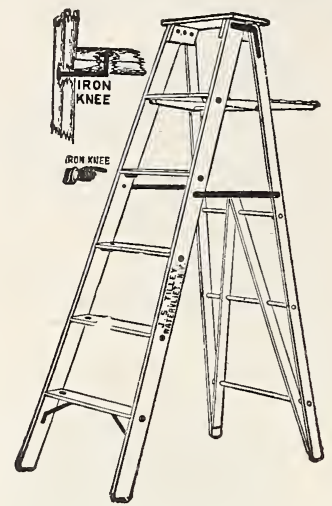

PARIS STEP LADDERS
(Very strong)

$6 \mathrm{ft} \ldots \ldots \ldots \ldots 2.25$

$8 \mathrm{ft} \ldots \ldots \ldots \ldots 2.75$

GEM STEP LADDERS $10 \mathrm{ft}$.

" "

" " " $\quad 5 \mathrm{ft} \ldots \ldots \ldots \ldots \ldots 1.20$

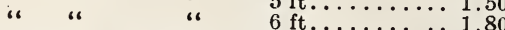

" " " $8 \mathrm{ft} \ldots \ldots \ldots \ldots 2.40$

COMMON LADDERS.-Tilley's best quality.

Stock length, $10,12,14,16,18,20,24$ and $26 \mathrm{ft}$.

Price, $10 \mathrm{ft}$. to $18 \mathrm{ft}$. $20 \mathrm{c} \mathrm{ft}$., $20 \mathrm{ft}$. to $22 \mathrm{ft} .22 \mathrm{c}$

$\mathrm{ft}, 24 \mathrm{ft}$. to $26 \mathrm{ft} .24 \mathrm{c} \mathrm{ft}$.

LADDER HOOKS.-Each ........ $\$ 1.00$

BEST EXTENSION LADDERS. - Sure lock, safest extension made, price $24 \mathrm{ft}$. to $36 \mathrm{ft}$. inclusive,

$35 \mathrm{c}$ per $\mathrm{ft}$.; $38 \mathrm{ft}$. to $44 \mathrm{ft}$. inclusive, $40 \mathrm{c}$ per ft.;

$48 \mathrm{ft}$. to $52 \mathrm{ft}$. inclusive, $50 \mathrm{c} \mathrm{per} \mathrm{ft}$.

WIRE FLY KILLERS.-Price......10c and 15c

CAN OPENERS. - Price........25 and $35 \mathrm{c}$

WINDOW BRUSHES. - All Bristles ..........75c

“

Handles, extra ......................... Large to 50

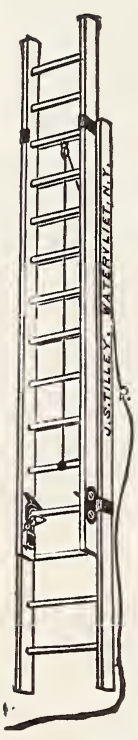

Extension

Ladder

COMMON ASH SIFTER. -Large size, galvanized, $50 \mathrm{c}$.

THE HUSTLER ASH

SIFTER.-Fits a barrel or can, Price without can........\$6.50 ROTARY ASH SIFTER. .\$.4.50 CENTRAL ASH SIFTER... 1.25 CENTRAL COVER.-EXtra........... 1.25

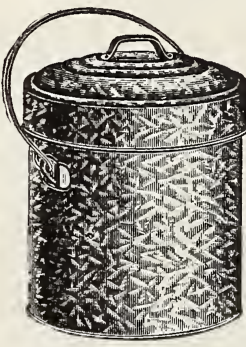

Garbage Pail

COAL HODS.-Galvanized. ..65e to $\$ 1.25$ GALVANIZED ASH CANS. $\$ 4.00-4.50-5.00$ GALVANIZED GARBAGE PAILS, With Common Ladder covers, ......\$1.75, 2.25, 2.50 and 2.75 METAL POLISH.--Per can 40c, 50c and $75 \mathrm{c}$ SCRUB BRUSHES. - With handle, .......... DAIRY QUEEN OR DUCK SCRUB ........ 35e and 50c

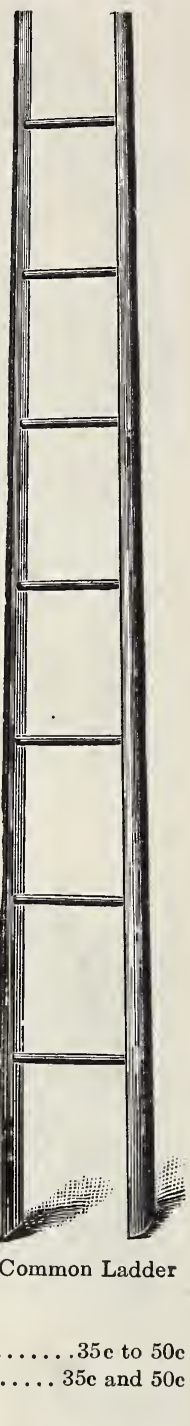

$.75 \mathrm{c}$ to $\$ 5.00$

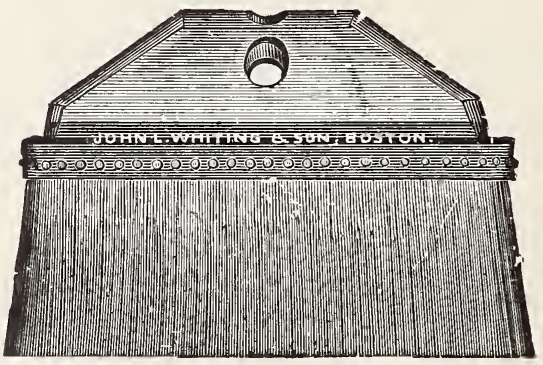

WHITE WASH LIME.Bbl. \$3.25; Selected lumps per lb. 3c.

ALABASTINE.-A splendid wall coating, much better than Kalsomine, etc. -ready for use by adding cold water-many shades, per pkg. (5 lbs.) $70 \mathrm{c}$ to $\$ 1.15$.

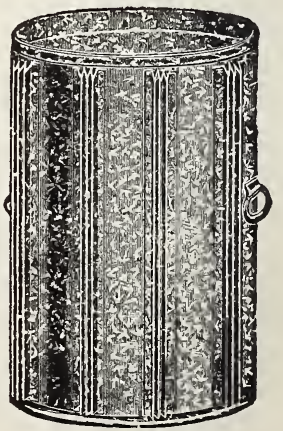




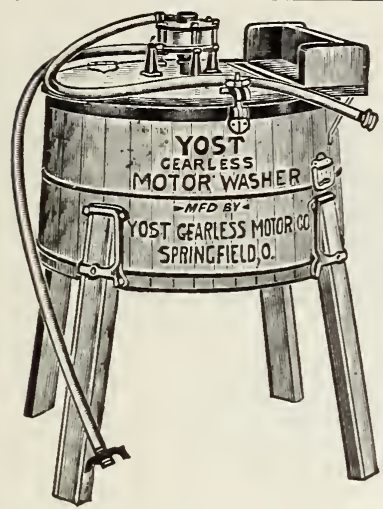

Majestic Washing Machine

Operated with crank and balance wheel, a splendid machine. Probably the best hand power washer. Price $\$ 12.00$

Geyser Vacurum Washer $\$ 17.00$

Yost Motor Washer Operated by water power by connecting with faucet.

Wash Boards, $50 c, 65 c, 85 c, \$ 1.00$.

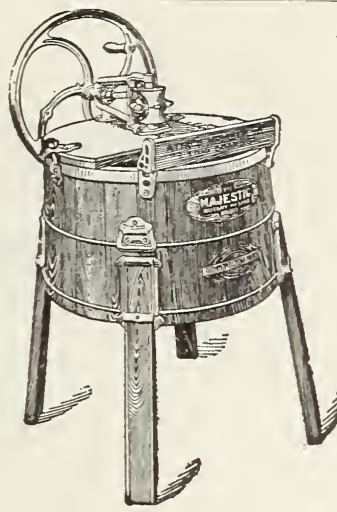

CLOTHES WRINGER (WARRANTED)

No. 350 , Family size, warranted ...............\$4.50 No. 351 Laundry size ......................... . . . . . .

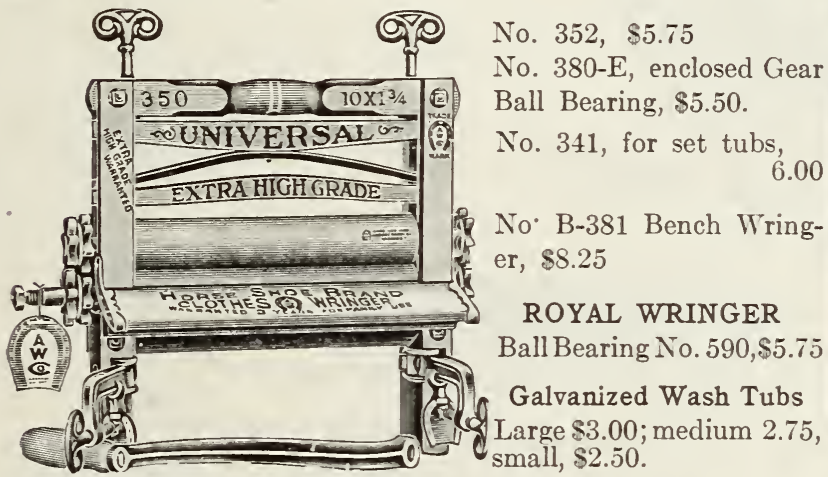

OBLONG CLOTHES BASKET. -4 sizes,.......85c, $\$ 1.00, \$ 1.10$ and 1.25 Hand Made............... $\$ 2.25$ CLOTHES LINES.-Cotton, $50 \mathrm{ft} ., 40 \mathrm{c} ; 75 \mathrm{ft}$., $60 \mathrm{c} ; 100 \mathrm{ft.,} 80 \mathrm{c}, \$ 1.25$ and 1.75 .

CLOTHES LINES. - Wire coil, $100 \mathrm{ft} \ldots \ldots \ldots \ldots \ldots \ldots \ldots \ldots \ldots \ldots \ldots \ldots \ldots \ldots$

CLOTHES LINE PULLEYS - . . . . . . . . . . . . .

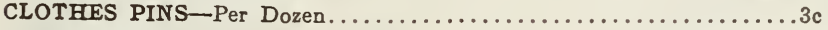

MOP STICKS. - Each............................ $25 \mathrm{c}$ and $45 \mathrm{c}$

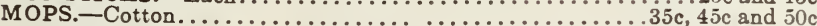

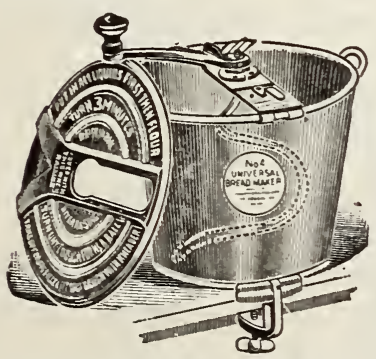

ONIVERSAL BREAD MIXER -

Regular gize, No. $4 \ldots \ldots \ldots \ldots, 3.50$

Large size, No. 8 ............. 4.00

\section{MOP WRINGER}

Family size $\$ 2.00$ and $\$ 2.50$ Hotel size, $\$ 3.00$

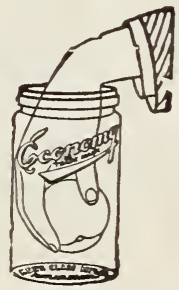

ECONOMY FRUIT JAR - The best yet, no rubber rings, self-sealing, air tight, large at top. Keeps perfectly meats, fish, vegetables or fruit. Pints Per Doz. 1. 35 Quarts " " 1.50 Two Qts. “2 2.00 Covers " " .30 Lifters Each .10

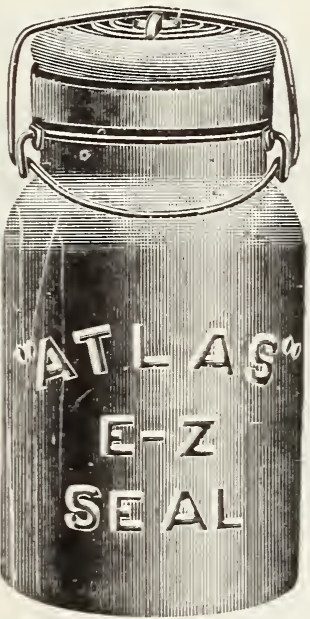

FRUIT JARS

E. Z. SEAL

$1 / 2$ Pints, $90 \mathrm{c}$; Pints $\$ 1$; Quarts \$1.10; 2 Quarts $\$ 1.40$.

Rubber Rings $10 \mathrm{c}$ and $15 \mathrm{c}$ per doz.

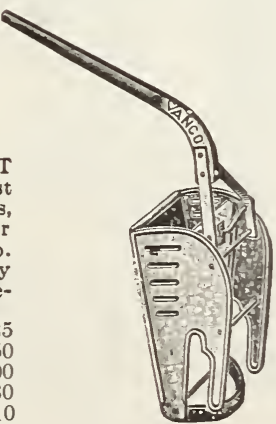




\section{BOB SLEDS}

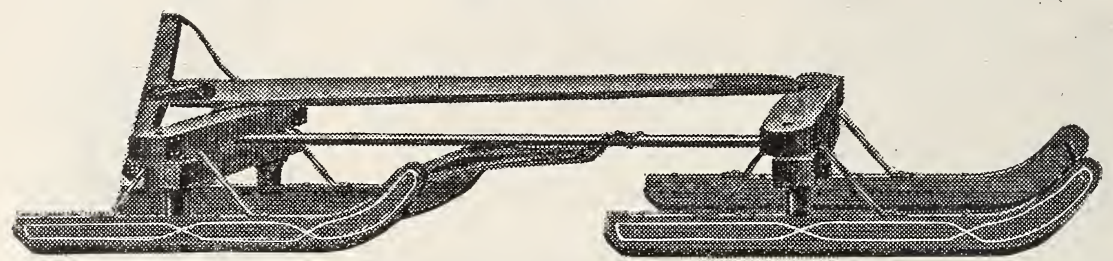

The "ONE KNEE" Sled is fast taking the place of the old "Three Knee." Our Best Sled is Eastern made of white oak and is a good one.

$\left.\begin{array}{ll}\text { No. } 3 \text { is a heavy one horse } \\ 2 & \text { " medium two "، } \\ 3 & \text { " heavy " }\end{array}\right\}$ Prices on Application

We also have an excellent Western Bob Sled-prices somewhat lower.
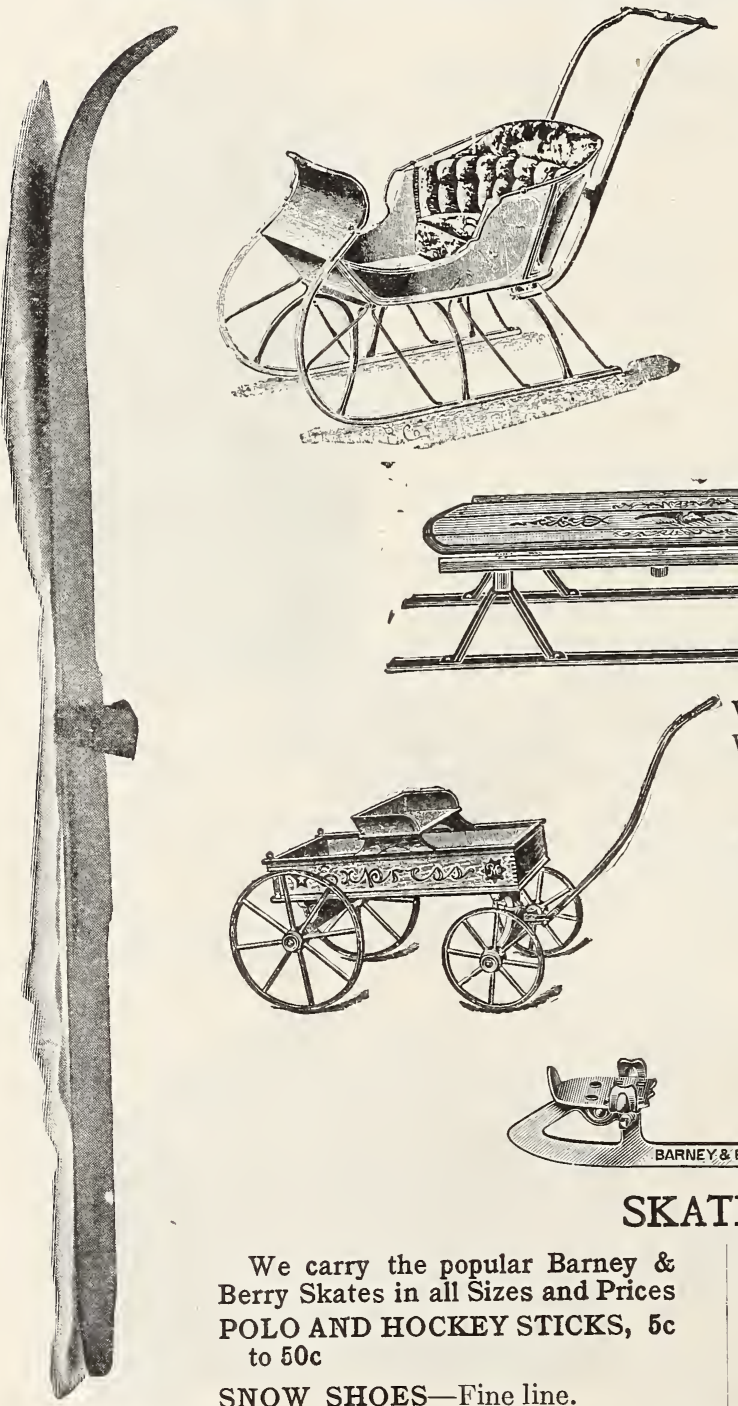

Paris Manufacturing Co.'s Sleds in Frames, Clippers, Baby Sleighs, and Double Runners.

The Genuine FLEXIBLE FLYER and the FIREFLY SLEDS in all styles and prices.
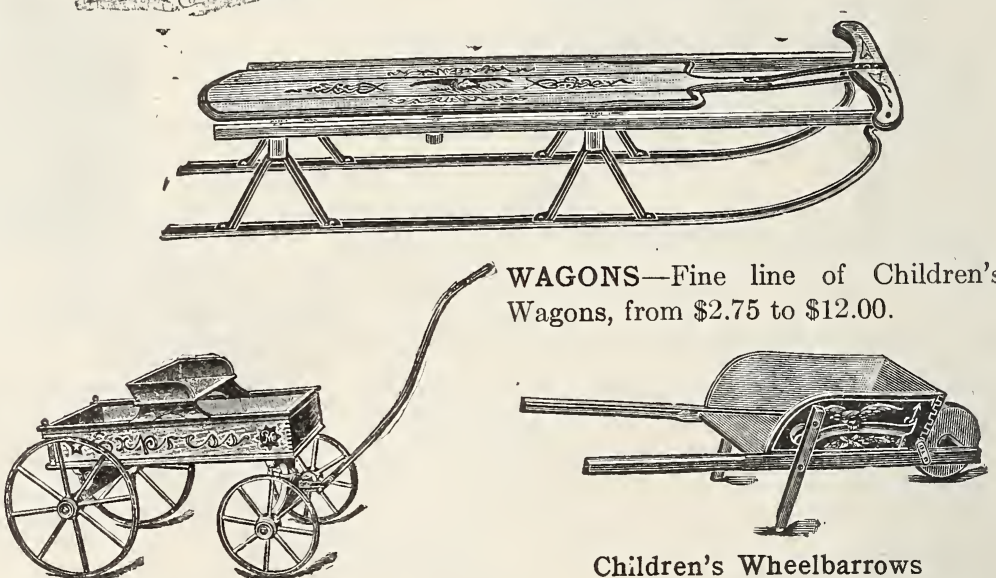

Children's Wheelbarrows

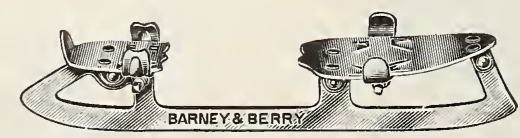

\section{SKATES}

We carry the popular Barney \& Berry Skates in all Sizes and Prices POLO AND HOCKEY STICKS, 5c to $50 \mathrm{c}$

SNOW SHOES-Fine line.
NORWEGIAN SKIS. - Complete with steering pole, $\$ 1.75$ to $\$ 8.00$. TOBOGGANS. - In the popular sizes, from $\$ 3.00$ up. 


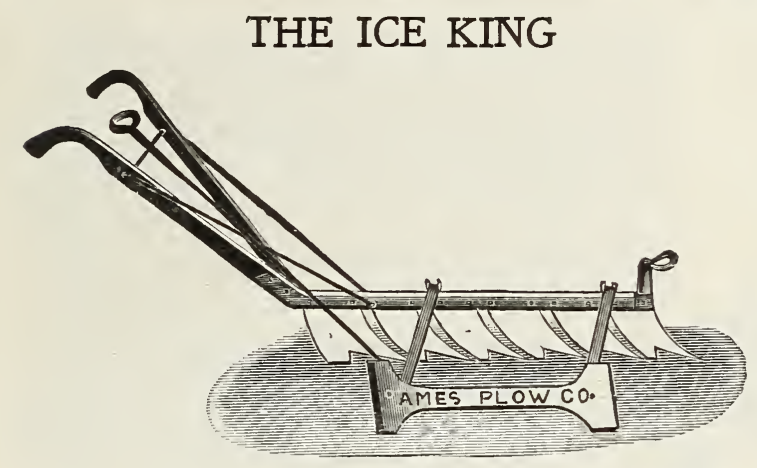

ICE PLOW

8 in. with 14 to 22 in. Adjustable

10 in. with 14 to 22 in. Adjustable Swing Guide, $\$ 50.00$

12 in. with 14 to 22 in. Adjustable Swing Guide, $\$ 55.00$

\section{ICE TOOLS}

COMPLETE ICE TOOL CATALOG SENT ON APPLICATION.

PULLEY BLOCKS.-Large assortment in stock.

ICE HOOKS.-

4 and 4 1-2 ft., each ............... \$1.35

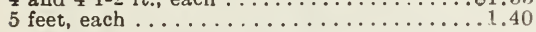

6 feet, each................. $\$ 1.50$

8 "

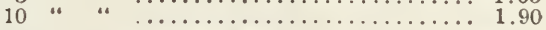

\section{0}

RING CHISELS, each,

BREAKING BARS, each,

SPLITTING FORK, 2-tined, each,

FORK BAR, 3-tined, each,

NEEDLE BAR,

ICE CREEPERS.-Per pair,
$\$ 1.75$

6.50

6.50

6.50

4.00

$25 \mathrm{c}, 30 \mathrm{c}$ and $35 \mathrm{c}$
ICE TONGS.-Boston Pattern, swell handle. No. 0 , opens 13 in. No. 1, " $141 / 2$ in. No. 2, “ $161 / 2$ in. Drag or stowing, long handle, HOISTING TONGS.Adjustable Claw, Solid Claw points,
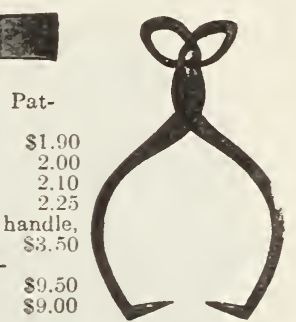

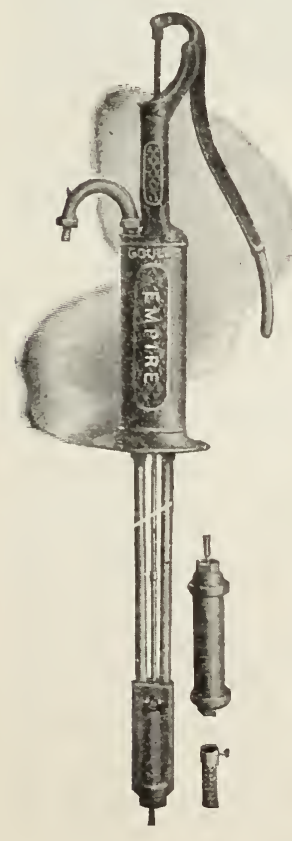

"Empire" Double Acting Force and Lift Pumps-Adapted for shallow or deep wells. Cylinder is Brass Lined. Takes 11/4 in. suction pipe.

No. 1362-4 - as arranged for wells up to $26 \mathrm{ft}$. $\$ 18.00$ As arranged for deeper wells,

$\$ 19.00$

Above prices do not include pipe below the upper valve.

\section{RUBBER BUCKET CHAIN PUMP} A POPULAR LOW-PRICED PUMP. Curb with heavy castings.......\$1.00 Tubing, best spruce, per foot..... .15 Chain, galvanized, per lb....... .15 Buckets, "Crosby"............. .15 Buckets, "Boston"................15 Rub Irons................. .15 We will be pleased to figure the cost of

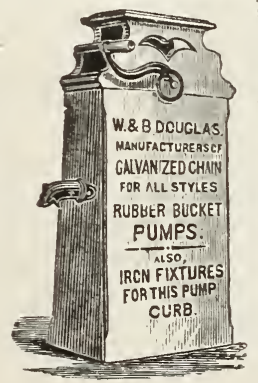

Pump complete if ${ }_{\text {iyou }}$ give us depth of well. Pitcher Pumps, No. $1, \$ 3.75$; No. $2, \$ 4.00$; No. $3, \$ 1.25$.

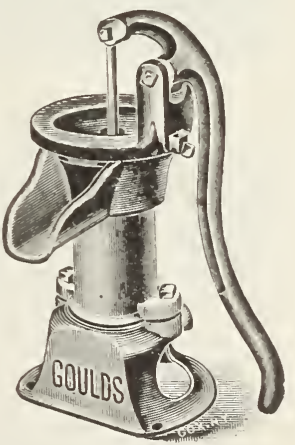

Pitcher Pump, No. R-416 \$5.00.

Pump Leathers, (Plunger) 20c and $35 \mathrm{c}$.

(Valve) 20c and 35c.

Well Points for driving, each $\$ 2.50$. 


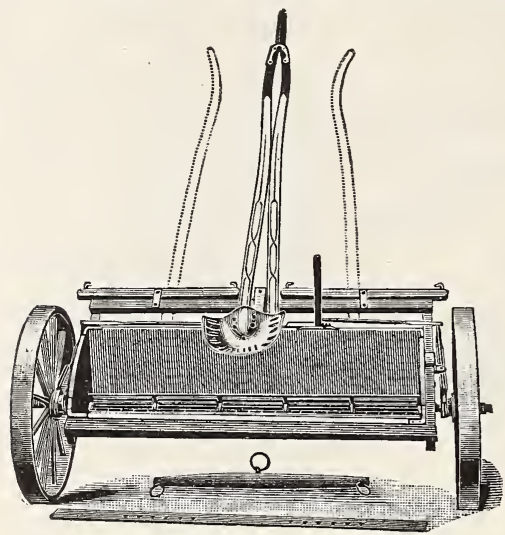

STEVENS' FERTILIZER SOWER.-For sowing fertilizer either broadcast or in drills by horse power. $5 \mathrm{ft} .10 \mathrm{in}$., $\$ 60.00 ; 8 \mathrm{ft} .3$ in., $\$ 66.00$; Special cut off attachment, extra, $\$ 4.00$.

\section{STEVENS' HAND FERTILIZER SOWER.-}

For sowing fertilizer broadcast on lawns, etc. Hopper is 34 in. long.

Price $\$ 15.00$

\section{Perfection Drill and Fertilizer Sower}

This machine will form a drill from 3 to 10 inches deep, and will drop into the drill any fertilizer at the rate of $100 \mathrm{lbs}$. to $3,000 \mathrm{lbs}$., to the acre. Price $\mathbf{\$ 2 2 . 5 0}$.

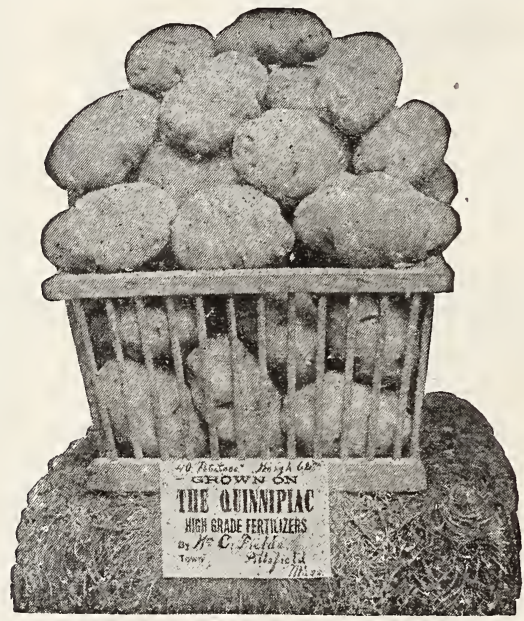

\section{QUINNIPIAC}

\section{FERTILIZERS}

\section{THE GREAT CROP PRODUCERS}

AVAILABLE PLANT FOOD.-Is what the farmer is looking for when he buys commercial fertilizers.

That is just why the QUINNIPIAC GOODS stand so well.

They contain this plant food in the available form and in the right proportions to secure good results.

The trade conditions are seriously affecting the fertilizer and chemical market. Prices given are those prevailing at time of going to press, and are subject to change without notice.

\section{HIGH GRADE PRINCIPAL BRANDS}

QUINNIPIAC MANURE,-Special attention is called to this brand as being as well formulated and as well balanced as any fertilizer on the market up to date. Per $100 \mathrm{lb}$. bag, $\$ 3.75$. Per ton, $\$ 72.00$.

QUINNIPIAC CORN MANURE,-For field, fodder or sweet corn, also used for grain. Per $100 \mathrm{lb}$. bag, $\$ 3.00$. Per ton $\$ 58.00$.

QUINNIPIAC POTATO PHOSPHATE.- As a potato grower it has won and maintained a high standing and an enviable reputation. Per $100 \mathrm{lb}$. bag, $\$ 3.00$, Per ton, $\$ 58.00$.

QUINNIPIAC GRASS AND LAWN FERTILIZER,-A top dressing for lawns, meadows and pastures. It acts quickly and produces a luxuriant growth of grass. It pays to use it. Per $50 \mathrm{lb}$. bag, $\$ 2.50$. Per $100 \mathrm{lb}$. bag, $\$ 4.50$. Per ton, $\$ 85.00$.

QUINNIPIAC PURE BONE MEAL.-Made from absolutely pure bones, finely ground and in the best mechanical condition. Per lb. 5c Per $100 \mathrm{lb} . \mathrm{bag}, \$ 4.00$. Per ton, $\$ 70.00$.

CEREAL AND ROOT.-An excellent fertilizer for the vegetable Garden as well as for Corn and Potatoes. Per $50 \mathrm{lb}$. bag, $\$ 2.00$, Per $100 \mathrm{lb}$. bag, $\$ 3.50$ Per ton $\$ 66.00$. 


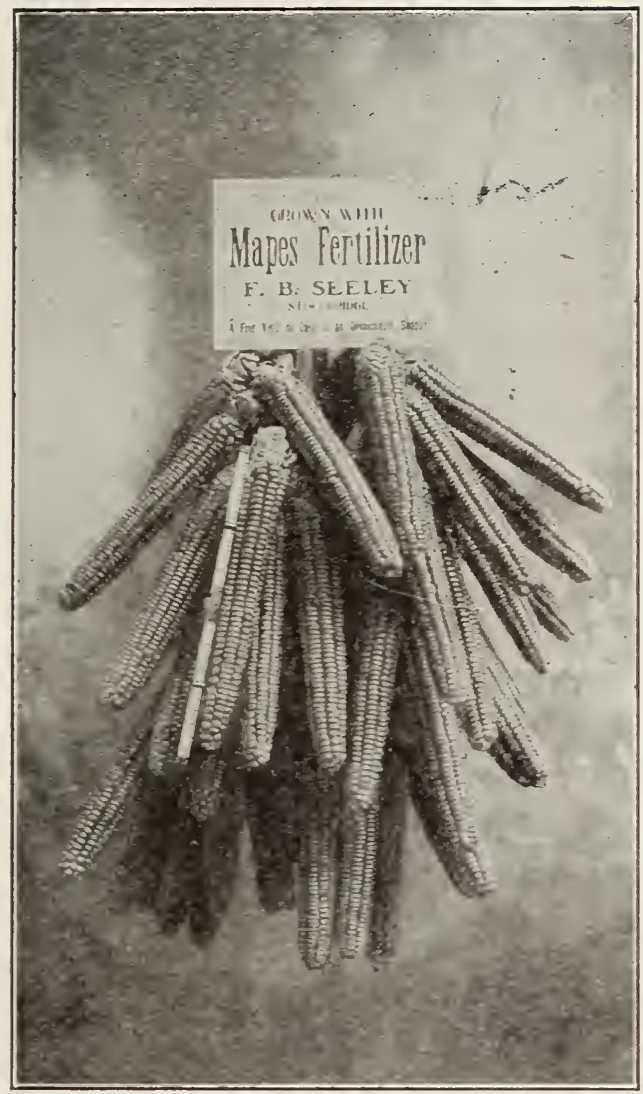

\title{
The Mapes Manures
}

\author{
For All Soils \\ and for all Crops
}

BASIS:

Pure Bone Made Soluble No Rock Used

THE TRADE CONDITIONS ARE SERIOUSLY AFFECTING THE FERTILIZER AND CHEMICAL MARKET. PRICES GIVEN ARE THOSE PREVAILING AT TIME OF GOING TO PRESS, AND ARE SUBJECT TO CHANGE WITHOUT NOTICE.

\section{PRINCIPAL BRANDS}

MAPES POTATO MANURE.-For Potatoes, Early Vegetables, Fruit, Sweet Corn, etc., Per 100 lb. bag, \$4.25; Per ton, \$\$2.00.

MAPES CORN MANURE.-Also for Sweet Corn, Fodder Corn, Hungarian Grass, Millet and Seeding Down to Grass. Per $100 \mathrm{lb}$. bag, \$3.75. Per ton, \$72.00.

MAPES GENERAL CROP-Per $100 \mathrm{lb}$. bag, \$3.25. Per ton $\$ 60.00$.

We can supply you any other brand of Mapes Fertilizers upon application, and will be pleased to quote you prices on same.

We can recommend the above fertilizers as being derived from the best sources of plant food, and we are confident their use will prove this, and the results will be satisfactory and pleasing to you. 


\section{AGRICULTURAL CHEMICALS and}

\section{FERTILIZING IMATERIALS}

\section{PRICES ON APPLICATION WHERE NOT GIVEN.}

Owing to trade conditions we are unable to obtain or offer any Potash except such as is contained in our regular commercial mixed fertilizer and in the wood ashes.

MURIATE OF POTASH.- 80 to 85 per cent muriate of potash. Not obtainable.

DOUBLE SULPHATE OF POTASH AND MAGNESIA.-48 to 52 per cent sulphate of potash; 35 to 40 per cent sulphate of magnesia and not over 2 1-2 per cent chlorine; 26 to 28 per cent actual potash. Not obtainable.

HIGH GRADE SULPHATE OF POTASH.-90 to 95 per cent sulphate of potash; 50 to 52 per cent actual potash. Not obtainable.

KAINIT. -23 to 25 per cent sulphate and muriate of potash; 12 to 13 per cent actual potash. Not obtainable.

SULPHATE OF MAGNESIA (Keiserite)—50 to 55 per cent sulphate magnesia.

NITRATE OF SODA.-94 to 96 per cent purity. Per 100 lbs. $\$ 8.00$; per lb. 10c.

SULPHATE OF AMMONIA.-24 3-4 to 25 1-4 per cent ammonia.

DRIED BLOOD. -12 to 14 per cent ammonia.

" " " $\quad 10$ to 12 " $\quad-8$ to 10 "

DISSOLVED BONE BLACK. - -15 to 18 per cent soluble and available phosphoric acid

" 6 " -13 to 15 " " "

PLAIN SUPERPHOSPHATE.-(acid phosphate)—per $100 \mathrm{lb}$. bag, $\$ 2.00$; per ton, $\$ 38.00$. FINE GROUND TANKAGE-6 to 7 per cent ammonia; 30 to 35 per cent bone phosphate

\begin{tabular}{|c|c|c|c|c|c|c|c|c|}
\hline 66 & 66 & 66 & -7 to 8 & "6 & 66 & 25 to 30 & 66 & "6 \\
\hline 66 & 66 & 66 & -8 to 9 & "6 & $" 6$ & 20 to 25 & 86 & " \\
\hline 66 & 66 & 66 & -9 to 10 & 66 & " & 15 to 20 & "6 & 66 \\
\hline
\end{tabular}

ASHES.—Canada.—Unleached. Per $100 \mathrm{lb}$. bag, $\$ 2.00$; Per ton, $\$ 35.00$. Subject to change.

\section{DRY GROUND FISH.}

BONE.-“Quinnipiac Bone Meal”-per cwt., \$4.00. "Raw Bone Flour"-per cwt., \$4.50.

"Raw Bone Meal”- per cwt., \$4.50. Cracked Bone “Oatmeal”-per cwt., \$4.50.

PURE NOVA SCOTIA GROUND PLASTER.-Per $100 \mathrm{lb}$. bag, $\$ 1.25 ; \$ 20.00$ ton.

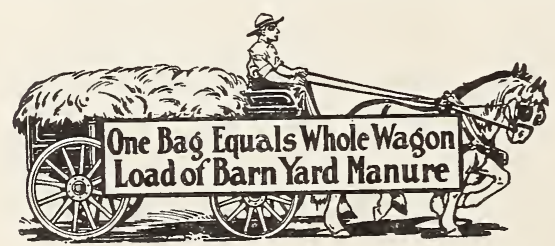

PULVERIZED SHEEP MANURE.-5 $\mathrm{lb}$. pkg., 40c; per $25 \mathrm{lb}$. bag, $\$ 1.25 ; 50 \mathrm{lb}$. bag, $\$ 1.75 ; 100 \mathrm{lb}$. bag, $\$ 2.75$. Per ton, $\$ 50.00$. CLAY'S FERTILIZER.-Imported, Prices on application. GUANO.-Peruvian.

SCOTCH SOOT.-Imported, $100 \mathrm{lb}$. bag, $\$ 5.00$. 
SEEDS.

ARTICHOKE,

Asparagus,

Beans,

Beets

Bird Seed,

Broccoli,

Brussels Sprouts,

Buckwheat,

Bulbs, Flowering,

CABBAGE,

Carrots,

Celery and Celeriac,

Chervil and Chicory,

Chives,

Corn Salad,

Corn,

Cress or Pepper Grass,

Cucumbers

DANDELION,

EGG PLANT,

Endive,

Flower Seeds,

GARLIC,

Gourds,

Grass Seed,

HEMP,

Herbs,

Horse Radish,

Hungarian Grass,

KALE or BORECOLE,

Kohl Rabi

LAWN GRASS,

Lettuce,

Leek,

MILLET

Melon, Musk and Water,

Mustard,

Mushroom Spawn,

NASTURTIUM,

OATS,

Okra or Gumbo

Onion, Onion Sets,

PARSLEY,

Parsnip,

Peas,

Peppers,

Pumpkins,

Potatoes

RADISH,

Rape,

Rhubarb,

SAL'SIFY or Vegetable Oyster,

Special Grass Mixture,

Spinach,

Squash,

Sunflower,

Sweet Peas,

TARRAGON,

Tobacco,

Tomato,

Turnip,

Vetches,

IVHEAT

TOOLS, FERTILIZERS, IN-

SECTICIDES, ETC.

AGRICULTURAL Chemicals,

Alabastine,

Animal Meal,

Aprons, Rubber.

Ashes,

Axes,

BABCOCK Tester and Pipette,

Bottles and

Acid Measure,

Bags, Seamless,

Bags, Feed,

Bands, Leg,

Bars, Crow

Barrows, Canal,

Barrows, Garden.

Baskets,

Baskets, Bottle Carrying.

Bells, Cow,

Bells, Sleigh,

Binder, Grain and Corn,

Bits and Braces,

Blankets and Pins, Horse

Bone, Cracked,

Bone Meal,

Boots, Lawn,

Boilers, Farmer's,

Bordeaux Mixture.

Bottle Filler.

Bowls, Wood

Page

2 Boxes, Butter

2-3-4

4-5

Brackets, Flower Pot.

Bread Mixer

Brooders and Stoves,

Brooms, House, and Whisk,

" Barn,

Brushes, Counter,

"i Horse,

Lather,

Paint 71 , White Wa

"Window and Scrub,

Buckets, Well,

Bug Death,

Bulb, Putty,

Butter Boxes, Shipping,

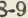

" " Mould

" Spades and Ladles,

,. Workers,

CALF MEAL,

Calf Cordial,

Canes, Bamboo,

Cant Hooks,

25 Cans, Ash and Garbage,

10

25-26

Can Openers

Caponizing Sets,

Cards, Horses and Cattle,

Carriers, Butter,

10

10

$10-11$

11
$5-26$

11

11 Cement, Rubber and China,

12 Char

23 Chamois,

6 Charcoal,

Chick Boxes,

12-13 Chick Feed

13 Chisels, Cold,

13

15

16 Choride Lime,

16 Churns,

17 Chute, Window Coal,

25-26 Clippers, Horse and Toilet,

17 Clothes Dryers and Frames, 87-88

Clothes Line Posts,

7 Clothes Line Pulleys,

5 Clover,

18 Combs, Curry and Mane.

18 Concrete Hardener,

23 Coolers, Milk,

24 Cork

25 Cork Screws,

8 Corner Bead,

19 Corn Husker,

19-20 Corn Binder,

26 Cows Relief

26 Cradles, Grain

Creamers, Cooley,

Crocks,

94 Cultivators, Hand,

$$
\text { Horse, }
$$

Cultipacker,

Cure, Roup, Cholera, Gape,

Cutters, Bone and Clover,

59

63

Lever, Hay,

Slaw,

63 " Stricture,

80 Cuttle Bone

DAIRY GODODS,

Death to Lice

53 Diggers, Post Hole,

27 Diggers, Potato,

27-89 Dilators, Teat

69 Dog Bread.

67 Dressing, Harness,

82 Drill Seed

Hand Stone,

42 Dumping Wagon

1 Dusters, Counter.

75-92-94 EDGERS, Turf,

75-92-94 Egg Carriers,

48 Eggs, Nest,

48 Eggs, Nest,

50 Engines, $\$ 4$ and

66 Evaporating Lamp.

68 Evaporator

$33-34-36-39$

Page ' Eveners,

Page

FARMOGERM,

Faucets,

79 Feed, Poultry.

89 Feeders, Calf,

61

2-73 Fencing, inside back cover and 77-78

86 Fertilizers and Sowers, 92-93-94

82 and inside back cover.

79 Files,

81 Flails,

79 Floats, Masons,

8 Floral Sets.

88 Flower Bed Guard,

Flower Stems,

50 Flower Supports,

41 Flue Lining,

67 Poultry. Cattie,

67 Forks, Barley and Coke, 42

$65 \%$ Ensilage, 42

68 “" Harpoon, 60

40 “ Hay, Hay, 42

70 " Manure and Spading, 42

88 " Weeding,

63-68 " Wood, Stable, 67

83 Fountains, Poultry, $\quad 76$

76 GATHERERS, Fruit, 40

67 Gauge, Cream, 63

66 Germozone,

85 Germ I 63

60 Gimlets, 42

60 Glass Cutters, $\quad 40$

70 Glazing Points, $\quad 40$

$\begin{array}{ll}\text { Glazing Points, } & 40 \\ \text { Glue, } & 42\end{array}$

$\begin{array}{ll}\text { Glue, } & 42 \\ \text { Grafting Wax, } & 59\end{array}$

54 Grass Catcher, 48

4 Hooks, 41

81 Gravel, Bird,

75 Grinding, 81

73 Grindstones, $\quad 87$

75 Grindstone Fixtures,

61 Grinders, Knife and Tool, $\quad 87$

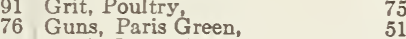

50 Guns, Paris Green,

$\$ 2$ HAIR, Plastering, 54

4-65 Halters,

53 Hammer, Nail, Rivet, Tack, 61

81 " Hand Sledge, Stone, 70

88 Handles, 52-59-88

Harness, 53-81

8 Harrows, 31-32

Hatchets,

81 Hay Caps,

Hay Racks,

Headers, Barrel,

76

$\begin{array}{ll}79 & \text { Hitching Rings, } \\ 54 & 81\end{array}$

34-86 Hocks, Mason's,

34-57 Hods, Mason's,

59 Hoe, Horse, 35-37-38-39

63 Hoe, Horse, 35-37-38-39

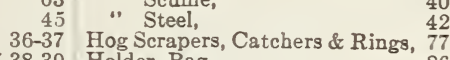

Holder Bag,

74 Hook, Bird C'

74 "Cant or Log,

85 " Brush,

82 "Grass,

9 Potato,

67 "Ice,

6-70 Hopper, Dry Feed, 74

76 Hose, Band and Couplings, 46

78 “ Nozzle Holders, 46

39 "Menders and Pliers, 46

Hovers, Reels and Washers,
$72-73$

Hovers,

I grometer,

70 ICE CREEPERS,
54

79 Incinerators,

42-48 Incubators,

73 Insecticides, 50-51-76

74 JACKS, Scaffolding, $\quad 87$ 
KNIVES, Asparagus, Page

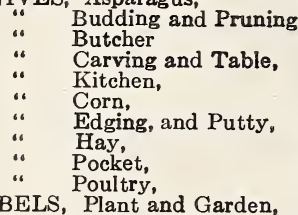
"“ Cattle and Sheep,

Ladder Hooks,

Lamps and Burners, Incubator, 76

Lantern and Burners,

Lath, Metal, Globe and Holders,

Lawn Boots,

“. Mowers,

Leaders, Cattle and Bull,

Lenox Remedies,

Levels,

Lice Killer,

I ime,

Lines, Garden,

Loaders, Hay,

Locks, Pad.

MANE COMBS,

Manger, Corner,

Manure Spreader,

Marker and Furrower,

Marline, Tarred,

Master Builders' Hardner,

Mastica,

Mattocks

Mats, Hot Bed,

Maul, Cast Iron,

" Woodchoppers,

Measures, Dry,

Measuring Rods,

Mills,Bone,

"Cider and Fanning,

“. Grist,

Milk Bottles and Caps,

Milk Bottle Filler and Cases,

Milk Mash,

"Tubes,

Mixer, Bread,

Mops, Rubber,

Cotton and Sticks,

Mortar, Red,

Moss,

Mowers, Horse Lawn,

Mowers, Hand,

Mowing Machines,

Mowing Machine Sections and Repairs,

Mulcher,

NECK YOKES,

Neponset Papers,

Nests, Wire,

Netting, Poultry,

Nikoteen and Nicoticide,

Nozzle Hose

OIL, Axle, Machine and Gas Engine,

“ Harness and Separator,

$$
\text { Cans, }
$$

Ox Bow Pins,

Ox Muzzles and Buttons,

PAILS, Dairy and Cream, Dinner,

Fibre and Stable,

Galvanized,

“ Sap,

Paint,

Paint, Roofing,

Pans, Milk, Paper, Building and Roofing,

Wax, Tissue and Manila 45

Parers, Apple,

Paris Green,

Paroid Roofing,

Pencils,

Pickers, Fruit,

Picks, Railroad and Contractor's 52

Pins, Clothes,

Plant Food

Planter, Corn,

Potato

Plaster Board

Plaster, Mason's and Wall,

Plaster, Land,

53-67

41
47
$7-48$

-48
56

61

3.3

55

55
-75

77

5-46

82

67

$67-68$
$63-67$

82
$5-71$

55
0 Pliers,

Plows,

Polish, Metal,

79 Points, Well,

79 Polo Sticks,

41 Pokes, Horse,

2 Poppers, Corn,

Potash,

Posts, Clothes Line,

76 Posts, Steel,

Pots, Flower,

Pots, Watering,

Poultry, Feeding Box,

Pruners,

Press, Wine or Lard,

Pulleys,

Pumps,

Pump Leathers,

hia

izors, Strops and Hones,

1 Reel, Garden,

35 " Hose,

41 " Clothes,

55 Repairs,

41 Revolvers,

59 Ridgers

41 Rings, Bull,

78 " Key,

86 Rivets, Copper.

67 Rollers Garden

74 Roo Field,

83 , Roofing Cement,

85 Rope,

69 Rubbish Burner.

66 Rubber Jar Rings,

75 Rules,

67 SALT,

89 Sand,

67 Sanitary Feeding Box,

89 Saw Frames

54 Sawing Machines,

41 Saw Bucks,

56

50 Bucks, 59

- Ice and Meat.

- Pruning,

- Sets and Clamps,

Scaffold Jacks,

Scales,

Scrapers

crapers, Hog Steel, Road, Wheel
Tree,

Screen Sand,

Screen Cloth,

Screen Door and Window,

Screw Driver

1 Scythes and Snaths,

Separators, Cream,

Separator Oil,

Shaving Mugs,

82 Shears, Border, Hedge and

(4) Branch

“ Fetlock,

83 “ Pruning Sheep,

" Grass,

Sheep Dip,

lowers and Grape,

8 Shellers, Corn,

Shells, Oyster and Sea,

Shingles,

Shovels, Spades and Scoops,

9 Shovels, Snow,

1 Sieves, Oat,

5 " Flour

Silkaline,

Silos,

89 Silver Pine Healing Oil

34-35-39 Skates,

39 Sledges,

54 Sleds.

54 Slug Shot,

94 Snaps, Harness,
Page 46-78 Soap, Harness,

28-29-30-35 Soot,

88 Sowers, Fertilizer, 33-34-35-92

91 and inside back

90 Sowers, Seed, 33-34-35-36-39

83 Sponges,

79 Spouts, Sap, 83

51-94 Sprayers, and Parts, 43-46-49-51

87 Sprinklers, Lawn, 46

78 " Plant, 41-43-46

78 Sprouter, Oat, 74

43 Staffs, Bull, $\quad 67$

74 Stakes, Plant, 40

70-78 Stanchions, 62

41-59 Staples, Wire and Netting, $\quad 78$

83 Stone Boats, 70

$\begin{array}{ll}60-79-89-91 & 70 \\ 43-46-49-91 & \text { Stones, Axe, Scythe, }\end{array}$

91 Stove Lining, 45

67 Strainers, Milk, 67-68

81 Stretchers, Wire, $\quad 78$

62 Stricture Cutter, 67

61 Sulpho Napthol, 51

74 Sulphur, 51

71 Support, Carnation and Tomato, 40

Swing, Lawn, 87

\begin{tabular}{lr} 
TACKLE-Blocks, & 46 \\
\hline & $60-79$
\end{tabular}

$\begin{array}{rr}42 & 60-79 \\ -57 & 79\end{array}$

41 Tampers, $\quad 78$

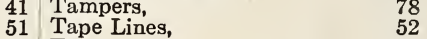

79 Tar,

40 Tar Paper,

46 Tedders, Hay,

Testers, Milk,

6-30-61 Testers, Pipette, 63

79

-38 Measure, 63

67 “" Egg, 74

42 Tethers, Animal, 81

83 Ties, Rope,

66 "Bale, 60

“ Corn,

$\begin{array}{ll}\text { Tile, Cow, } & 62 \\ & \end{array}$

Tobacco Stems, 51

Tobacco Dust and Extracts, 50-51

Toboggans,

$\begin{array}{ll}\text { Tongs, Ice, } & 91 \\ \text { Torches, } & 51\end{array}$

Torches, inside front cover

73 Traps, Rat, Mouse, Game, 79

9 Traps, Mole, 41

84 Trellis, Tomato, 40

59 " Wire, 43

59 Trowels, Garden, 40

41 Trowels, Mason's, 52

59 Trucks, 46-49-80-86

87 Tubing, Pump, 91

69 Tubs, Flower, 89

79 Turpentine, 71

79
53 Twines,

41 VANES, 68

87 Varnish, $\quad 71$

87 " Cemetery, 41

87 Vises, Cemetery, 41

59 WAGONS, 80-90

Dump, $\quad 53$

62 Wagon Shoes,

83 Water Barrel Truck, $\quad$ 46-49

Washers, Axle, 82

27 Washing Boards, Machines, 89

81 " Powder, Wyandotte, 65

41 Water Glass, 73

7-41 Watering Pots, 43

41 Waterproof Compound, $\quad 54$

86 Wedges, Wood Splitting,

75 Wedges, Axe, 59

75 Wedges, Axe, 5 '

$\begin{array}{lr}55 & \text { Wedges, and Shims, } \\ 52 & 70 \\ 7 \text { Weed Killer, } & 50-51\end{array}$

76 Weeders, Horse, $33-38$

82 " Hand, $40-46$

79 Whiffletrees,

41 Window Coal Chute, $\quad 53$

85 Wire, Fencing, 77-78

70 Wire Greenhouse, $\quad 41$

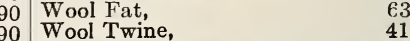

90 Wool Twine,
70 Wrenches, Monkey and Stilson, 61

90 " Scythe, 59

51 Wringers, Clothes and Mop, 89 


\section{LAWN FENCING}

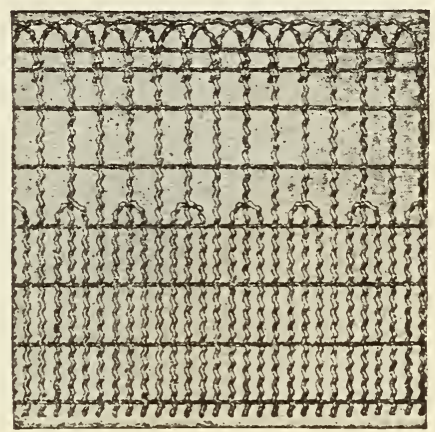

A very Neat and Attractive Lawn Fencing, Galvanized, well made and durable

No. 600-Double Fabric, as shown, 42 in. high, per lineal ft. $24 \mathrm{c}$ " 100 - 6 6 42 " 6 "6 "6 "6 $18 \mathrm{c}$

We are Agents for the

\section{Louden Barn Equipment}

If you intend building or remodeling we will be glad to send special equipment man to go over the LOUDEN plans with you

\section{The Nonpareil Broadcast Lime and Fertilizer Sower}

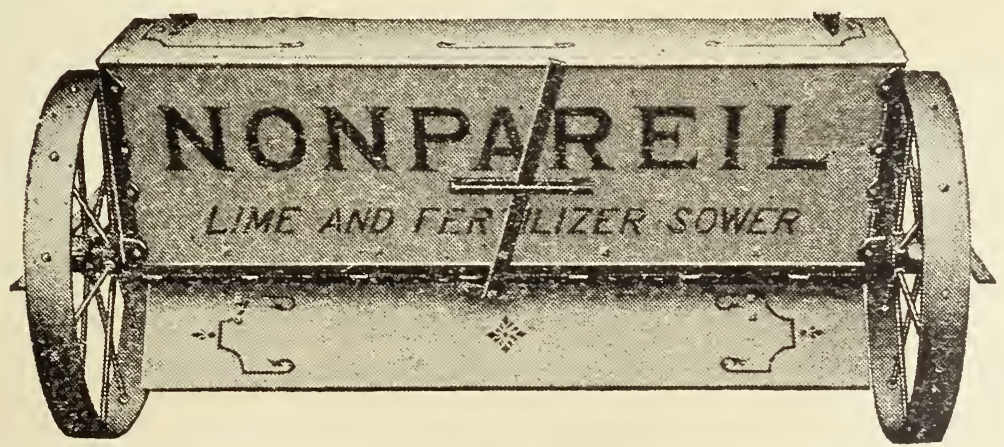

Hopper holds 10 bushels, sows 8 feet wide, will distribute from $100 \mathrm{lbs}$. to $5,000 \mathrm{lbs}$. per acre, weight $351 \mathrm{lbs}$.

Price Complete, $\$ 55.00$ 
